- BEACH EROSION BOARD

OFFICE OF THE CHIEF OF ENGINEERS

\title{
AREAL AND SEASONAL VARIATIONS IN BEACH AND NEARSHORE SEDIMENTS AT LA JOLLA, CALIFORNIA
}

TECHNICAL MEMORANDUM NO. 39 


\section{AREAL AND SEASONAL VARIATIONS IN BEACH AND NEARSHORE SEDIMENTS AT LA JOLLA, CALIFORNIA}

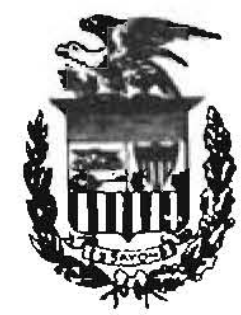

TECHNICAL MEMORANDUM NO. 39

BEACH EROSION BOARD

CORPS OF ENGINEERS 


\section{FOIREWORD}

An important feature in the research program of the Beach Erosion Board is a study of coastal sediments, with particular regard to establishing environmental sedimentary characteristics in the littoral zone as an aid in the analysis of littoral processes. An earlier report by F. P. Shepard and D. L. Inman, published as Technical Nemorandum No. 26 of the Beach Erosion Board, concerned volumetric sand movement on the shallow shelf between two submarine canyon heads at La Jolla, California, and concurrent wave observations. The report which follows concerns results obtained from extensive sampling and analysis of sediments in the area during the same period.

This report has been prepared at Scripps Institution of Oceanography in pursuance of Contract w-49-055-eng-3, as modified, which provides in part for investigating the variability of beach and shore materials. The author, Douglas L. Inman, is an Assistant Marine Geologist at Scripps Institution of Oceanography. He was assisted in the experimental work leading to this report by Jean Short in laboratory analysis, D. M. Pbole and R. A. Mills in heavy mineral counts, and by J.R. Horiarty and D. B. Saymer in drafting the figures. The writer expresses his appreciation to Professors Francis P. Shepard and George F. McEwen for their assistance and guidance during this work and to Robert S. Arthur for his valuable suggestions and careful reading of the manuscript.

Views and conclusions stated in the report are not necessarily those of the Beach Erosion Board.

This report is published under authority of Public Law 166, 79 th Congress, approved July 31, 1945. 


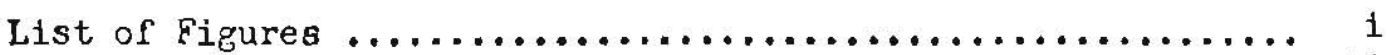

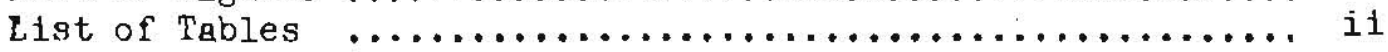

Abstract ...................................... 1

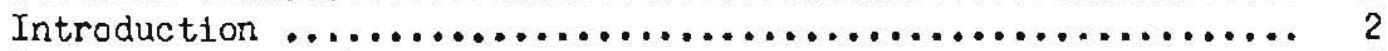

Description of the Area .............................. 3

Waves, Currents and Beach Changes ..................... 6

Exposure to Waves .............................. 7

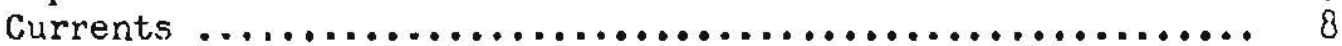

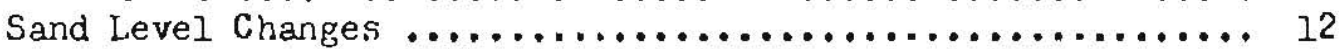

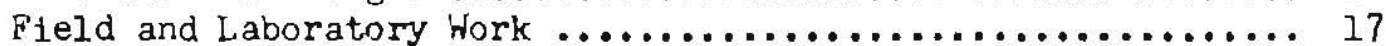

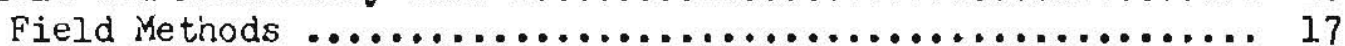

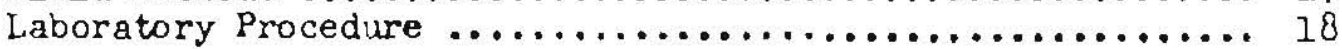

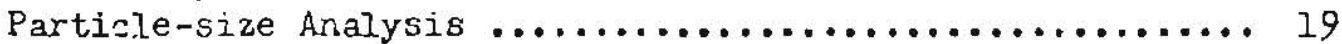

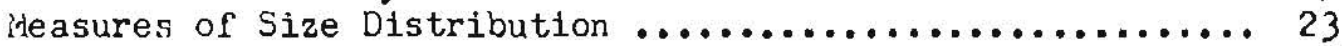

Comparison of Sieve and Settling Tube Data ............. 25

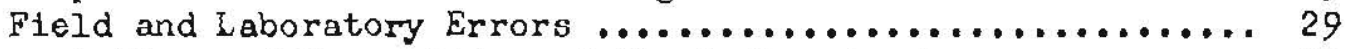

Description and Composition of the Sediments ............ 33

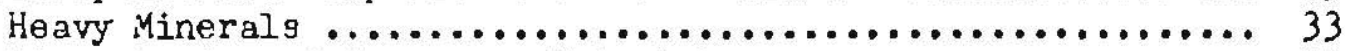

Distribution of Micaceous Material .................. 37

Carbonate Content ............................... 40

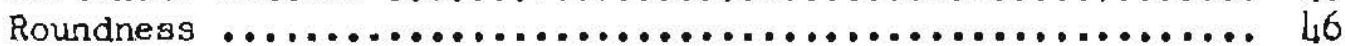

Particle-size Distribution .......................... L6

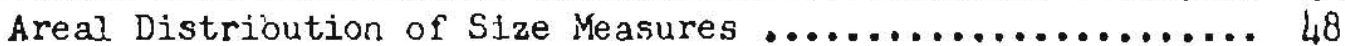

Comparison of sieve and settling tube data ........... 48

Median dianeters .............................63

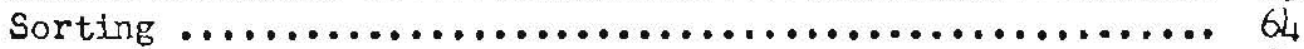

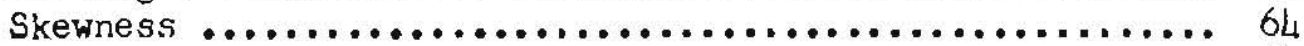

Sediment Distribution in Adjacent Areas ............... 64

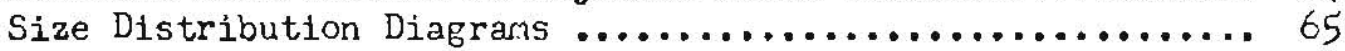

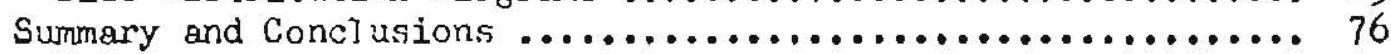

Bibliography ................................... 80

Appendix IA - IF .... Particle-size Distrioution aid Va\}. Selected Components for Repeated Pange Samples ........................... IA-1

Appendix II ........ Particle-size Distribution and Values of Selected Components for Supplementary

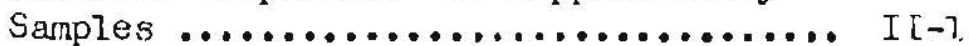

Appendix III ....... Sand Size and Beach Foreshore Slope .... III-? 


\section{LIST OF FIGURES}

Figure

1. Location map and index .......................... 4

2. Index of sample location ......................... 5

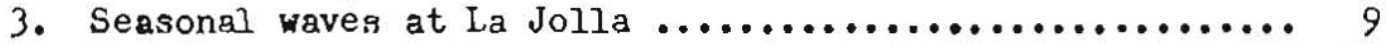

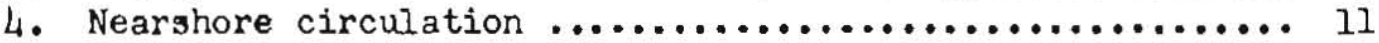

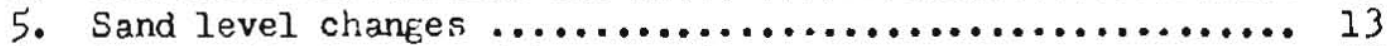

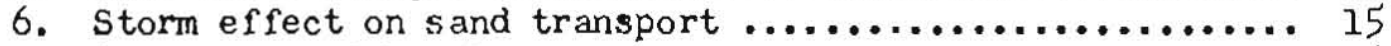

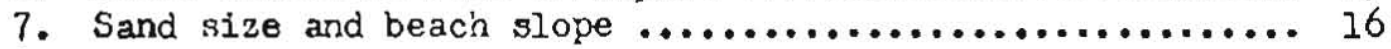

8. Conversion chart for phi and millimeters ............... 21

9. Fitting cumulative curve to settling tube-pipette data ... 22

10. Relation between phi median diametors ................ 27

11. Relation between phi deviation measures $\ldots \ldots \ldots \ldots \ldots \ldots \ldots . \ldots 28$

12. Cumulative curve of typical beach sample ............. 35

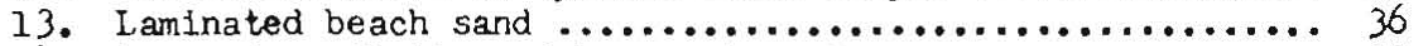

14. Areal distribution of heavy minerals $\ldots \ldots \ldots \ldots \ldots \ldots \ldots \ldots . \ldots . \ldots$

15. Cumulative curve of micaceous sample ................ 39

16. Areal distribution of micaceous material ............ 47

17. Areal distribution of carbonate ................... 42

18. Seasonal variation of sediment components along D range .. 43

19. Roundness of quartz grains ...................... 44

20. Cumulative curves of typical sediments .............. 47

21. Areal distribution of phi median diameters ............ 49

22. Areal distribution of phi deviation measures ........... 52

23. Areal distribution of phi skewness measures ............ 55

24. Seasonal variation of size distribution along $D$ range .... 58

25. Variation of size distribution along $U$ range ........... 61

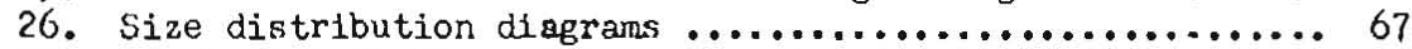

27. Areal distribution of bottom sediment types ........... 75

\section{LIST OF TABLES}

Table Page

1. Comparison of sleve and settling tube data ............ 26

2. Errors in measures of size distribution ............. 31

3. Distribution of light and selected heavy mineral fractions ................................ 34 


\title{
NEARSHORE SEDIMENTS AT LA JOLLA, CALIFORNIA
}

\author{
by \\ Douglas L. Inman \\ Assistant Marine Geologist \\ Scripps Institution of Oceanography
}

ABSTRACT

The nature of the seasonal distributions of certain physical properties of sediments on the beach and shallow shelf area between two submarine canyon heads was studied at $S_{c}$ ripps Institution of Oceanography. The investigation was made from five series of bottom samples obtained periodically from June 1949 to May 1950 along a predetermined grid. Each series consisted of about 130 samples extending from the beach foreshore out to depths of approximately 200 feet. The emphasis in the laboratory analysis of the sediments was on the distribution of particle size. Other properties such as shape, roundness, heavy mineral and carbonate content were also measured.

Topographic surveys showing the changes in sand level were made concurrently and on the same grid as the sediment sampling operations. These surveys indicate that beach material migrates seaward during period of large waves and landward during small waves. The most pronounced changes in sand level occur in depths less than $30 \mathrm{feet}$, but some seasonal effects may extend to greater depths. The greatest change in sediment size also took place from the beach foreshore out to depths of about 30 feet. In this zone the sediments tended to be coarser during the winter and spring when the beaches were cut back, and finer in the fall following the summer fill.

The areal distribution of physical properties indicated that the sediments varied in a systematic manner from one locality to another. It was found that the sediments could be divided into types on a basis of particle-size distribution, and that these types were characteristic of the environment of deposition. The beach and intercanyon sediments were grouped into three general environmental types. Type I consists of beach foreshore sands, which were the best sorted sediments in the area. Sands from the surf zone were designed as Type IIa, and were characteristically coarser and more poorly scrted than sediments farther inshore or offshore. These grade into Type IIb which were found on the relatively level portions of the shelf from the surf zone out to depths of approximately 
100 feet. Type IIb sediments are predominantly well sorted, very fine sands. Type III sediments are found seaward of Type II $b$ in areas where the bottom slopes more than about 1 in 15. These "slope" sediments usually have more silt, and are characterized by positive skewness and poorer sorting.

During times of large waves sediment is lost to the area by transportation into the submarine canyons. Replenishment of this sediment is apparently due to transport around the head of the northern of the two submarine canyons, since the sand along the beach for five miles north of the canyon head is very similar to that in the intercanyon area and the littoral drift here is to the south. A much coarser and better rounded sand is found on the pocket beaches and on the shelf south of the southern canyon head.

\section{INTRODUCTION}

Along the southern California coast there is a seasonal migration of sand between the beaches and deeper water in response to the seasonal changes in wave height, period and direction of approach. In general the beaches build seaward during the small waves of summer and are cut back by high winter storm waves. Bottom surveys indicate that most seasonal offshore-onshore interchange of sand occurs in depths less than 30 feet, but that some seasonal effects may extend to greater depths. The purpose of this investigation was to determine the nature of the seasonal distributions of the physical properties of sediments in a beach and nearshore environment.

It was intended that the bottom ample stations and the repetition of sampling be spaced at such intervals as to show gradational properties if they exist in the sediments, either with respect to space or time. Concurrent with the field work, factors influencing sediment transportation and deposition such as wave height and period, currents, and tides were measured. The emphasis of the laboratory work was on the distribution of grain sizes, both as to sieve and hydraulic size, because it was felt that processes of sedimentation would best be reflected in these properties. Other properties of the sediments such as shape, roundness, heavy mineral and carbonate content which influence hydraulic size were also measured. Because much of the significance of a stody of this type is dependent upon the methods and accuracy of collecting and analyzing the sediments, this subject is treated in some detall under the section on field and laboratory work.

This is the third of a series of integrated investigations of nearshore processes along the beach and sandy shelf in the La Jolla area. The types of currents, and the relation between the nearshore currents and the wave conditions under which they were generated, were investigated first and published as "Nearshore water circulation related to bottom topography and wave refraction" (Shepard and Inman, 1950). The second 
investigation was of the seasonal changes in said level from the sumuner of 1949 to the summer of 1950. These were measured by surveys repeated at intervals of approxinately two months (Shepard and Inman, 1951b).

Concurrent with the sand level surveys, five series of sediment samples were obtained on a grid corresponding to the survey ranges and cross ranges. Each series consisted of about 130 samples extending from the beach foreshore out to depths of approximately $2 \mathrm{co}$ feet. In addition, both beach and bottom samples were obtained to the nort? and south of this grid.

Previous investigations of the relations betieen the size distribution of sediments and the environment of deposition have been undertaken by many workers. Perhaps the first and most rewarding study of the areal distrioutions of sediment properties was that by Krumbein and nberdeen (1937) in Barataria Bay, where they were able to demonstrate that the botton sediments varied in a systematic manner throughout the lagoon, and that the size distribution of the sediment could in general be related to the environment of deposition. Other notable investigations of this type include the study of areal variations of beach sands by Krumbein (1938) and Krumbein and Griffith (1938), and the sediment studies of Buzzards and Cape Cod Bays by Hough (1940, 1942).

On the California coast a similar environment to that of the present study was investigated at Pt. Mugu (Inman, 1950a and 1950b). It was found that the variations in size distribution with change in bottom topography were comparable to those at La Jolla. The present study, in view of previous investigations, strengthens the contention that there is a good correlation between sediment attributes and environment of deposition, and illustrates that detailed studies of the areal and seasonal distributions of sediment properties are valuable tools in the study of sedimentary processes.

\section{DESCRIPTION OF THE AREA}

The area of investigation is situated just north of La Jolla, California, where Point La Jolla forms a small hooked bay which opens to the northwest (see figures 1 and 2). The shelf area within the bay is cut by two main branches of a submarine canyon, which extends to within about 700 feet of the low-tide shore line. A fine sandy beach extends for a mile along the shore between the canyon heads. This section is called Scripps Beach and is teminated by rocky areas just south of each canyon head. The sandy shelf area between these canyon branches and the adjacent beach is the subject of this study.

The coast line extends in a nortiwesterly direction from La Jolla Bay and is fairly even, having no large irregularities for approximate]y 45 nautical miles to where Dana Point forms a rocky headland. The beaches along this section of coast are narrow and consist predominantly of fine sand interrupted occasionally by peoble and cobble foreshores. The beaches 


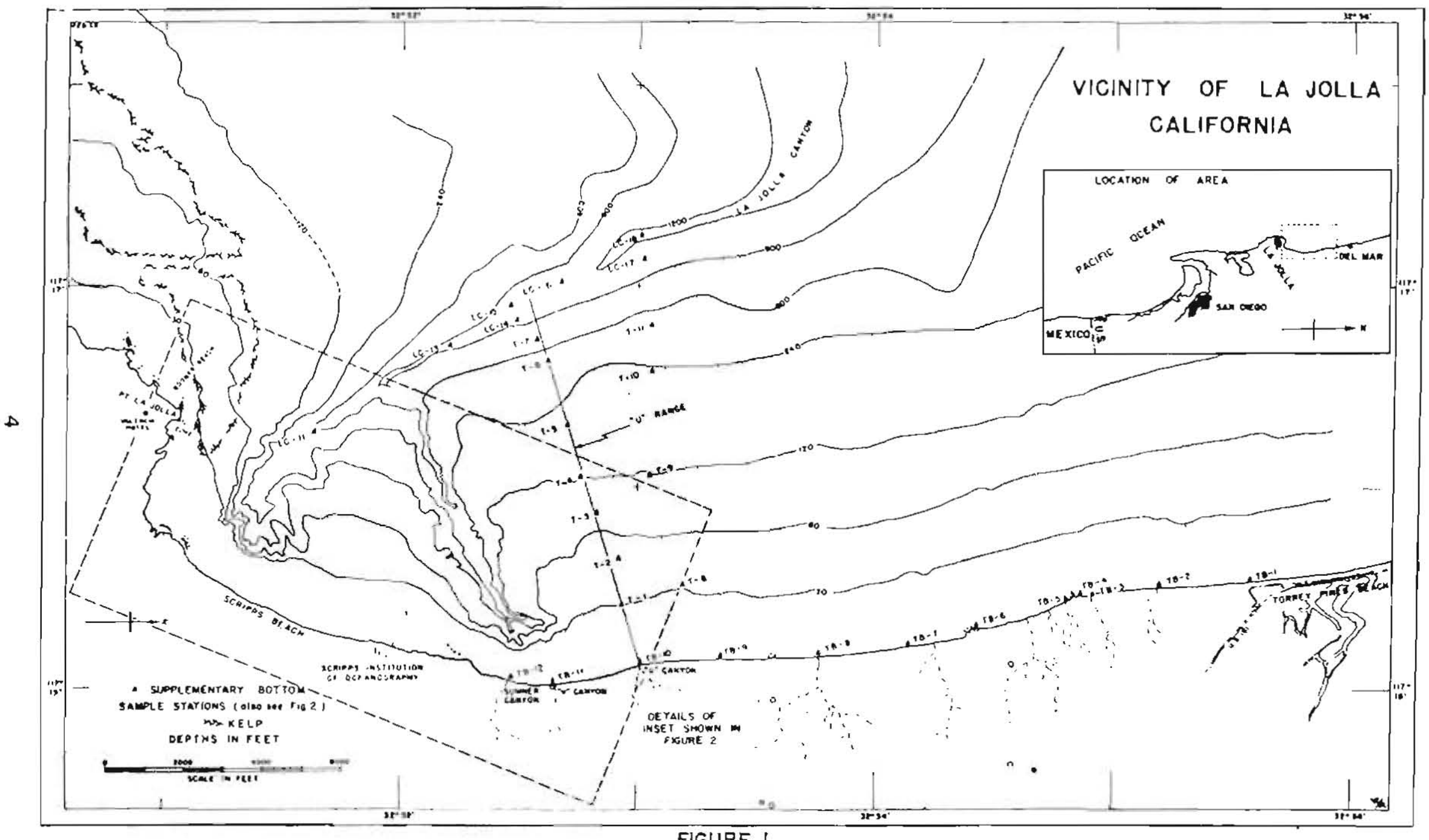

FIGURE I 


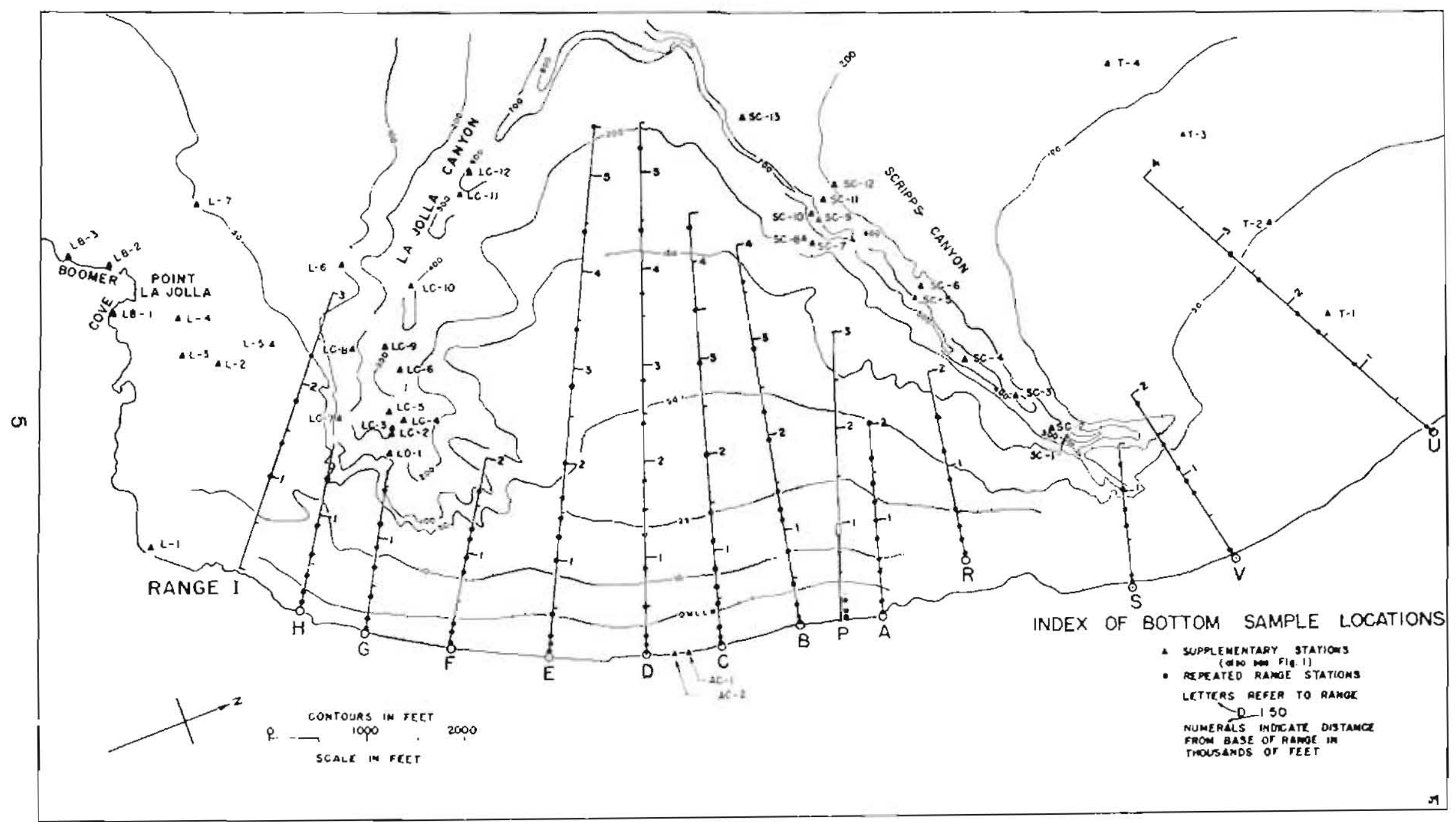

FIGURE 2 
are backed by steep cliffs of Tertiary to kecent sands, silts, and conglomerates. The cliffs rise from 10 to 400 feet above sea level and are interrupted occasionally oy intermittent strearns and tidal lagoons.

Point La Jolla to the south is a rocky headland of resistant Cretaceous and Eocene sandstones. Most of the Point is rock cliff wj.th a few coarse sand pocket beaches which are in marked contrast with the fine sands of Scripps Beach to the north. Also, the narrow shelf around Point La Jolla is rocky with small pockets of coarse to fine sand in contrast to the more regular slope and very fine sand covering of the shelf to the north.

It is thought that the major source of sand for the beaches to the nortic of La Jolla is from streams and cliff erosion, and that in general this material has a net drift to the south in response to the direction of wave approach. There is a tendency for the size of the beach material to decrease towards the south, and the finest sand along this section of coast is found on Scripps Beach.

Scripps and La Jolla submarine canyons form a natural sediment barrier so that any sand-size material supplied to the intercanyon shelf and beach area must enter the area shoreward of the precipitous canyon heads. Since the erosion of cliffs along Scripps Beach does not provide a significant quantity of sand (Shepard and Inman, 1951b), the major source of sediment must be from the north and must enter the area across a narrow 700-foot zone along range $S$ at the head of Scriops Canyon (see figure 2).

A considerable portion of the southerly littoral drift of beach sand must be lost in Scripps Canyon. Repeated surveys of the bottom topography in the vicinity of Scripps Submarine Canyon have shown that the sand portions of the shallow canyon heads exhibit al ternate filling and deepening (Shepard, 1951). liost changes occur at the heads of the canyon near relatively steep slopes, and show no apparent relationship to the seasonal cut and fill which occur on and near the local beaches in response to wave action. For these reasons it is thought that the periodic deepenings result from mass movements of sand in the form of slides from the shallow canyon heads or adjacent shelf into the deeper parts of the canyon, and as such represent a pemanent loss of sand from the littoral drift of this area. Repeated surveys in November 1949 indicated a loss of $3: i$ million cubic feet of sand from the narrow shelf near Scripps Canyon head. This was apparently the result of a slide which accompanied an earthquake.

\section{WAVES, CURIEENTS AND BEACH CHANGES}

Waves and currents are both important factors in the transportation of sediments in shallow water. Sand may be moved along the bottom by the stress exerted on the bottom by waves and currents, or it may be placed in suspension by wave and current turbulence and transported by currents. An important principle in nearshore processes is that whenever 
wave action is sufficient to move or put bottom sediments into suspension, any net current, however weak, may become important in sediment transportation. It is also possible that a net transport of sediment could exist in the absence of a net current if a horizontal gradient were to develop in the concentration of suspended material. Such a gradient does exist near the surf zone, where the concentration of suspended material is greater in the zone of breaking waves than it is seaward, and may result in an offshore transportation of sediments by diffusion.

Water motion associated with shallow water progressive waves is oscil.latory in nature, the motion under the crest being in the direction of wave propagation while that under the wave trough is in the opposite direction. As waves near the breaker zone, a differential develops between the crest and trough orbital velocities, the velocity under the crest exceeds that of the trough and becomes of shorter duration. In general the differential between crest and trough orbital velocities decreases as the rave height and frequency increase. However, the picture of wave motion in shallow water is considerably complicated by currents and by longer period waves or surges which in some cases may result from the fact that groups of high and low waves alternate in the surf zone.

In this connection, Munk (1949) concluded that the surf zone acts as a radiating line source which returns ajproximately one percent of the incoming wave energy in the form of two to four minute period waves which he termed "surf beat". Williams and Isaacs (1952) and Isaacs, et al. (1951) describe proceeses by which the seaward moving surf beat wave may be refracted and reflected, thus resulting in offshore regions of wave convergence and reinforcement. Their work suggests that Scripps and $\mathrm{La}$ Jolla suomarine canyons may result in convergence of surf beat along the outer portions of the intercanyon shelf (Williams and Isaacs, 1952, figure 4). A convergence of this type may be the reason for the relatively coarse sediments and the anomalies in sediment distribution which are found in this area (for example, figures 14, 16, 17, and 21).

Exposure to Haves

In an investigation of the seasonal variations in nearshore sediments it is useful to know the direction and type of waves to hich the area is subjected, the percentage of time that it is exposed to each type, and the effect of nearshore bottom topography in refracting waves. A statistical study of the seasonal character of waves approaching the La Jolla area from deep water has been made by the Scripps Institution of Oceanography (1947), and a detailed investigation of the effects on wave refraction of the irregular bottom topography in this area was made by Wunk and Traylor (1947). In addition, the significant wave height, period, and direction of approach were observed daily throughout the period of these sediment surveys, and the details of these observations are published with the report of' sand level changes (Shepard and Innan, 1951b). 
During the summer months of the observational period, 30 June to 5 October 1949, the waves had a mean breaker height at Station B (figure 2) of approximately 3 feet, and wtre characterized by two predominant wave types: (a) Waves with periods of 7 to 9 seconds aporoaching from a westerly direction, and (b) waves with periods of 13 to 17 seconds approaching from a southerly direction. These two types occurred with approximately equal abundance during the earlier part of the summer, with the latter type becoming more abundant during late summer (figure 3).

The fall, winter, and spring waves, 5 October 1949 to 10 May 1950, showed a much greater scatter in wave height, period, and direction of approach. The mean winter breaker height was higher than for summer breakers, averaging about 5 feet, and there was a greater abundance of waves from a northwesterly direction. Perhaps more important than the increase in average seasonal breaker height was the occasional occurrence of days having average breaker heights over 12 feet during winter stoms, in contrast to the maximum of $6 \frac{1}{z}$ feet which occurred for only one day during the summer months.

\section{Currents}

There appear to be at least two interrelated current systems which prevail in nearshore environments (Shepard and Inman, 1950 and 1951a);

(1) The coastal currents which flow roughly parallel to the shore and constitute a relatively uniform drift in the deeper water adjacent to the surf zone. These currents may be tidal currents, transient winddriven currents, or currents associated with the distribution of mass in local waters.

(2) A nearshore system which may be superimposed on the inner portion of the coastal current or in the absence of a coastal cur rent may exist independently. The nearshore system is associated with wave action in and near the oreaker zone and consists of: (a) shoreward mass transport of water due to wave motion, which carries water through the breaker zone in the direction of wave propagation, (b) movement of this water parallel to the beach as longshore currents, (c) seaward return flows such as flow along concentrated lanes known as rip currents, and (d) longshore movement of the expanding head of the rip current outside of the breaker zone. There are processes other than rip currents by which water is returned seaward. Heasurements show that a net seaward drift exists along the bottom inside of the breaker zone, while a shoreward movement of water occurs near the surface (Inman and Quinn, 1952).

The shoreward mass transport of water by waves occurs principally in wide lanes between rip currents. As a result, the surface circulation pattern takes the form of an eddy or cell with a vertical axis. The positions of the onshore transport and seaward return, or rip currents, are dependent on submarine topography, configuration of the shore line, 


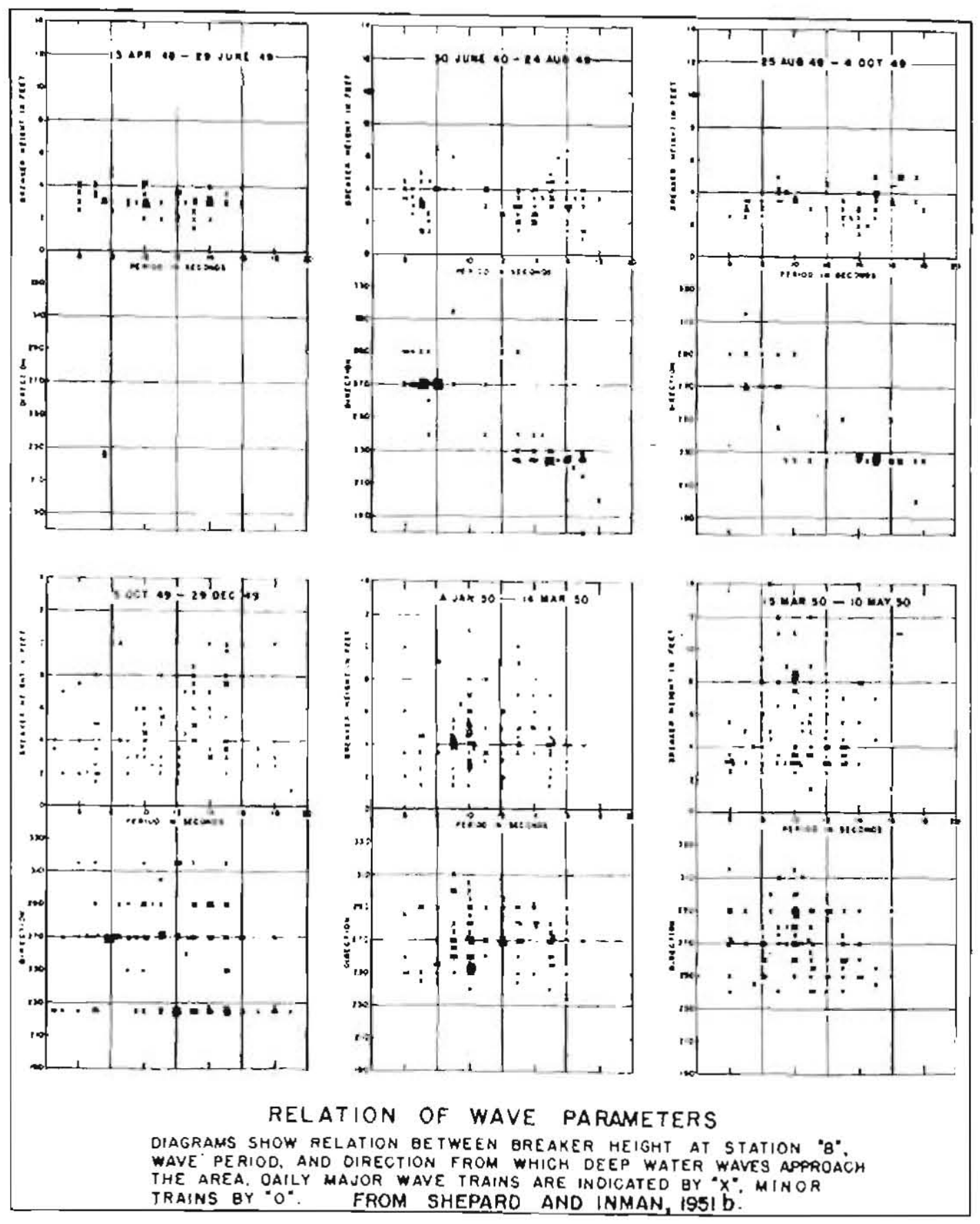

FIGURE 3 
and height, period and direction of the waves. The direction of the lon'shore current is primarily dependent on (a) the direction of approach of the breaking waves, and (b) the gradation in breaker height along the beach. The principle explaining the first case is that the momentum of the breaking wave transports water in the direction of breaking. In the second case, higher waves transport more water shoreward than low waves, and hence longshore currents commonly flow away from the zones of highest waves.

The complex canyon and shelf topography off Scripps Beach has a marked influence on the nearshore current system, particularly for. long period waves which "feel bottom" in deeper water and hence are more influenced by topography. In the case of swell having a period of approximately ten seconds or greater, the topography results in a great contrast of breaker height along the beach. The waves diverge over the submarine canyons and converge on the intercanyon shelf, causing high waves at the convergence near beach stations $C$ and $D$ and low waves opposite the canyon heads at stations $F, G, H, S$ and $V$.

The higher waves at the convergence cause more water to be transported shoreward at that point, which results in a neutral or divergent current at the wave convergence and longshore currents flowing to the north and to the south away from the convergence zone (figure 4 ). The longshore currents turn seaward as rip currents at varying distances from the wave convergence zone. Outside of the breaker zone the rip currents merge with the coastal current, and in cases where the coastal current flows towards the wave convergence, the circulation pattern is a complete circuit (figure 4 , station $C$ ).

In the case of long period waves the direction of deep water wave approach does not appear to be an important factor in determining the generalities of the circulation pattern. On the other hand, the topography causes less refraction for short period waves, so that the shorter the wave period the more important direction of wave approach becomes in determining the direction of flow of longshore cur rents. Waves with periods of 8 seconds or less that approach this area from the northwest or from south of west-southwest cause longshore currents to flow in the same direction, south or north as the case may be, for the entire length of Scripps Beach (Shepard and Inman, 1950, figures 7 and 8).

In general the long period type of circulation prevails throughout the summir months in response to the 13 to 20 second waves from the southwest. Even the short period waves of summer tend to maintain this circulation pattern because they usually approach from the west and therefore do not develop large breaker angles with the beach. The greater abundance of short period waves during the winter months, particularly Irom the northwest, resulted in a less stable overall circulation pattern, but a greater abundance of days when the longshore components of the currents were unidirectional for the entire length of the beach. 


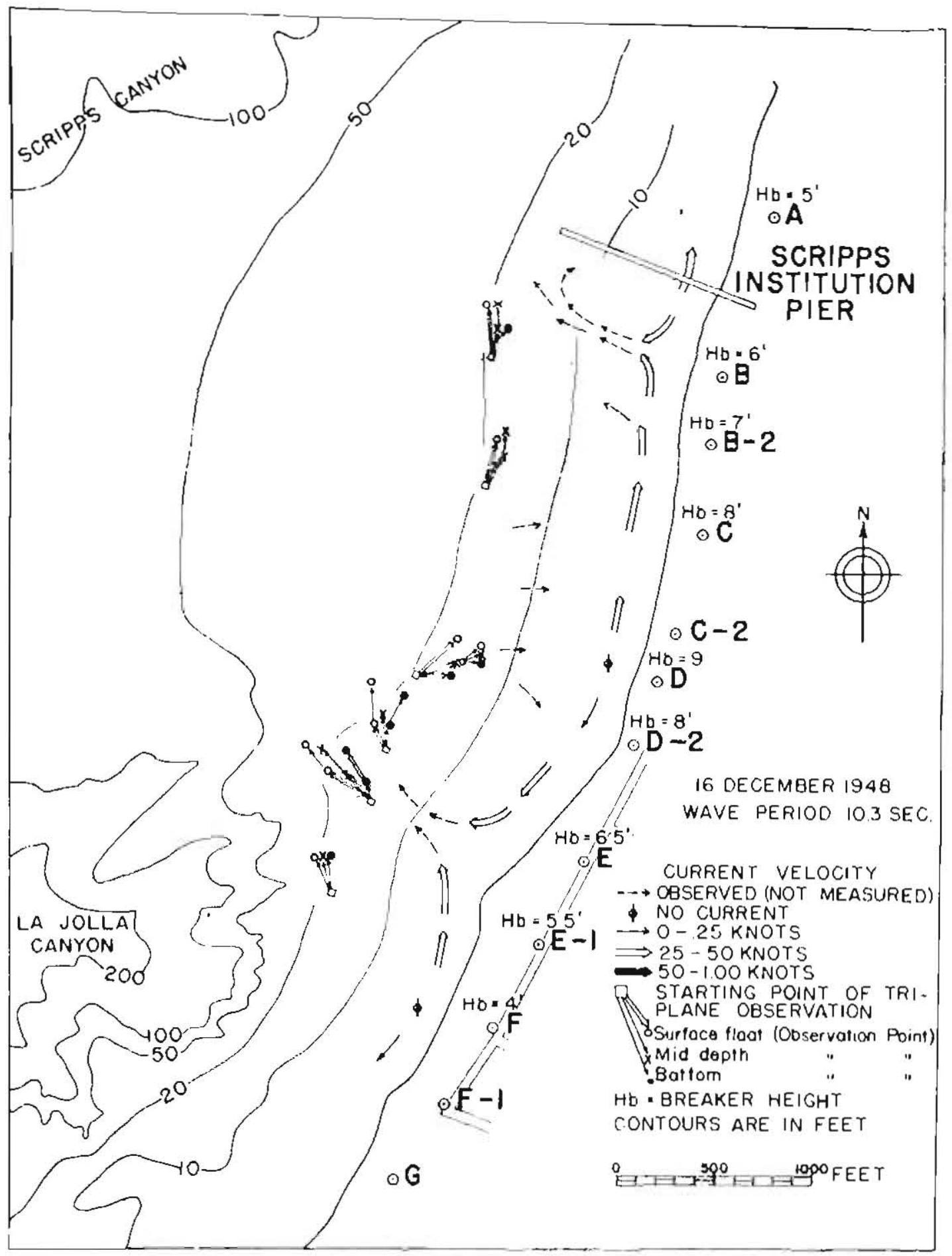

Figure 4. Typical nearshore circulation pattern at Scripps Beach resulting from waves with a period of ten seconds or greater and a northerly flowing coastal current. Note the diverging currents off stations $D$ and $F$, and the rip currents off $B$ and $E$ (from Shepard and Inren, 2950)。 
Thus, the seasonal variations in the direction of approach, period, and height of waves, results not only in seasonal variations in the nature and rigor of wave action, but also results in seasonal tendencies in the nearshore current system associated with the waves. It is probable that the longer period waves and surges such as "surf beat" also have seasonal tendencies that are important to nearshore sedimentation.

Sand Level Changes

Sand level changes along the beach and intercanyon sheif were determined by repeated surveys run along ranges A through $H$. The off shore portion of the ranges were surveyed by an amphibious vehicle (DUKW) equipped with a large-scale echo sounding device, and the inshore portion by running a line of levels from a leveling rod mounted on the DUKW to a beach transit station. Eight such surveys were made between April 1949 and hay 1950 and the data published in the form of isopleth maps showing the changes in sand level between successive surveys (Shepard and Inrian 19510).

The surveys showed that the greatest seasonal changes in sand level occurred between the beach and depths of approximately 30 feet, but that neasurable changes probably exiended to greater depths. In general, the beach and shallow water changes appear to be related to the character of the waves between each survey period. During the surmer months of June, July, and August when the waves were characteristically low and of long period, sand was deposited on the beach, causing the beach foreshore to build seaward and in general to become steeper. The fijl along the beaches was accompanied oy deepening in an area roughly parallel to the shore and averaging between 500 and 1000 feet offshore from the beach stations. The offshore deepening was most conspicuous in two areas to either side of the wave convergence zone approximately off stations $B$ to $C$ and $E$ to $F$ (see fizure 5 ). The beach fill was most pronounced at station $D$ where it amounted to a foot or more per month during the first few weeks of low summer waves. Once the beach became adjusted to suminer wave conditions the changes in sand level were less pronounced, al though the tendency was for the beaches to build somewhat throughout the sumer.

The first Jarge waves in the fall produced a general cutting back of the beach coreshore to a depth of several feet or more. The material eroded t'rom the forcshore was deposited in a band outside of and parallel to the surf zone, with the most marked fill occurring in the two zones on either side of the convergence where the summer deepening was greatest. The most pronounced cut occurred near the wave convergence at Station $D$ where the greatest sumner fill took place. As soon as the shallow area and the beach became adjusted to the larger waves of winter, additional rutting became minor, al though there was lateral shifting of sand along tine risreshore in response to the direction of wave approach. In general the beaches continued to erode somewhat throughout the winter and spring so that the beaches were most denuded in April and May. The small waves of summer resulted in a return of sand to the beach and shallow water 


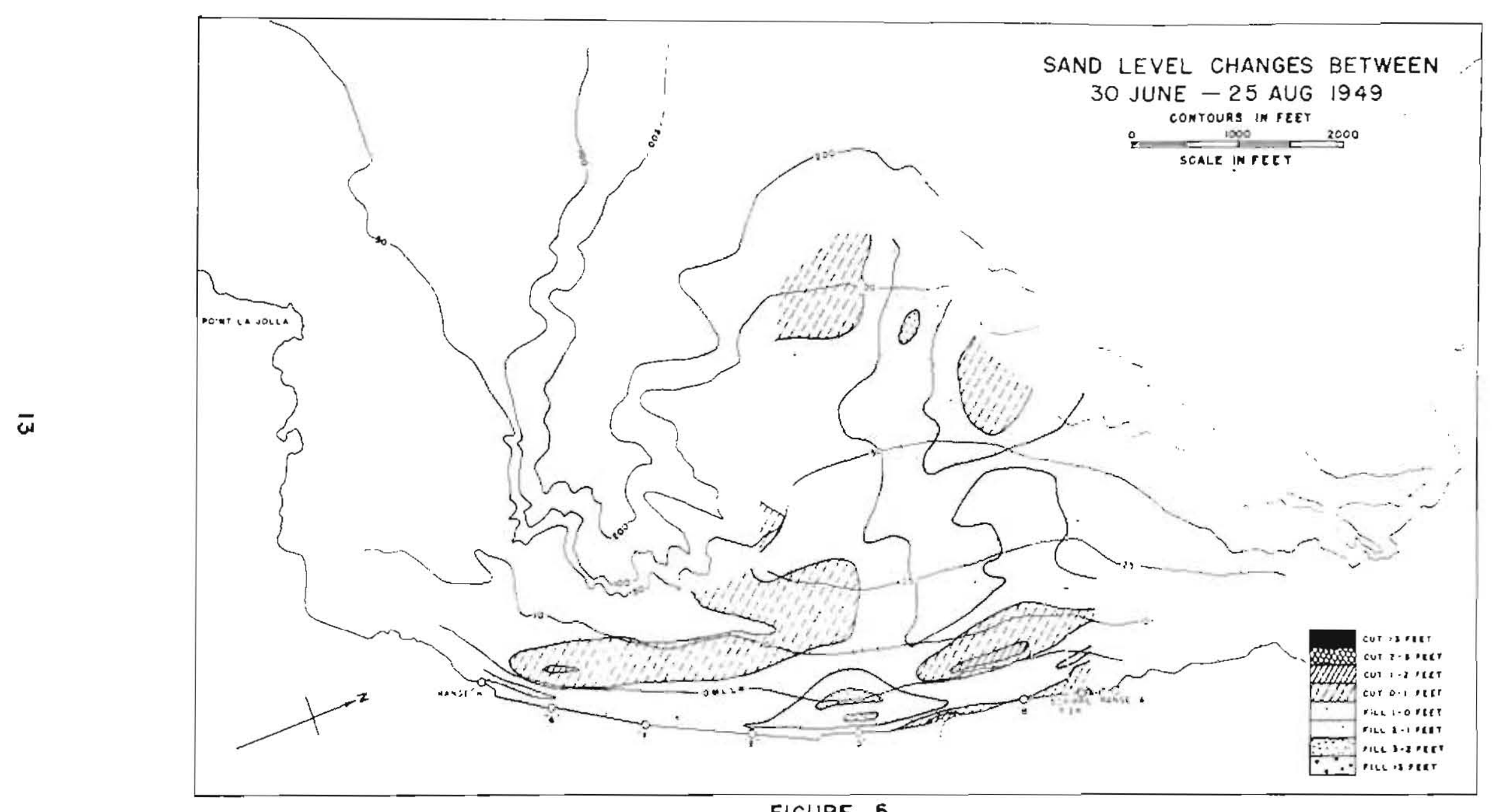

FIGURE 5 
area, thus completing the seasonal beach cycle.

The effects of a winter storm accompanied by high waves and wind from the northwest are shown in the isopleth map of the 30 December 1949 to 3 January 1950 sand level surveys (figure 6). The most noticeable change in the beach was a longshore transportation of sand towards the south by the strong longshore currents, and the deposition of this load along the southerly portion of the beach from station $G$ through $H$, where the waves were somewhat lower and the currents weaker. The storm resulted in a general smoothing of the beach profile. The beach berm and longshore bars and troughs that formed during the lower waves preceding the storm were eliminated (figure 6, insert), and the slope of the beach foreshore reduced. The small amount of cut along the beach is perhaps understandable in view of the series of large waves that occurred in the months preceding this storm. These large waves had presumably brought the beach somewhat into equilibrlum with large wave conditions. The high storm waves caused a decrease in beach foreshore slope at stations $P, B$, $C$, and D where deposition was confined to filling in depressions of previous longshore troughs, and the dominant change was erosion. To the south at stations $E, F$, and $G$ the combination of high waves and Iongshore fill resulted in building of the beach and preservation of the slopes existing before the storm, while erosion of the foreshore and deposition of fshore caused a minimum slope of 1.3 degrees at station $\mathrm{H}$. Before the storm there was a marked variation in the grain size of the beach material; following the storm there was little change in grain size from one end of the beach to the other.

The storm apparently produced changes in the sand level on the intercanyon shelf which resembled the beach changes in that there was deepening along the north portions of the shelf and deposition to the south. Th1s suggests that the waves or the currents set up by the waves and wind of a storm of this type are effective in producing shifts of sediment on the sandy shelf. A considerable portion of the sediments were presumably washed into the canyors and therefore lost to the area.

Whle there are cycles of beach cut and fill throughout the summer and winter in response to changes in waves and tides, the seasonal cycle described above is the most pronounced. The seasonal cycle is also reflected in the size of the sand and the slope of the beach foreshore. Both can change rapidly, and in a rather complex manner, as discussed above for storm conditions (figure 6).

Since the slope is dependent upon the sand size as well as other factors, the seasonal variation in both can best be shown where beach slope is plotted as a function of send size, and the Individual observations for summer and winter are indicated by different symbols. Such a plot for Scripps Beach (figure 7) shows that on the everage the beach foreshore slopes are less during winter months than for summer even though there is a tendency for the sand to be coarser-grained during the winter. 


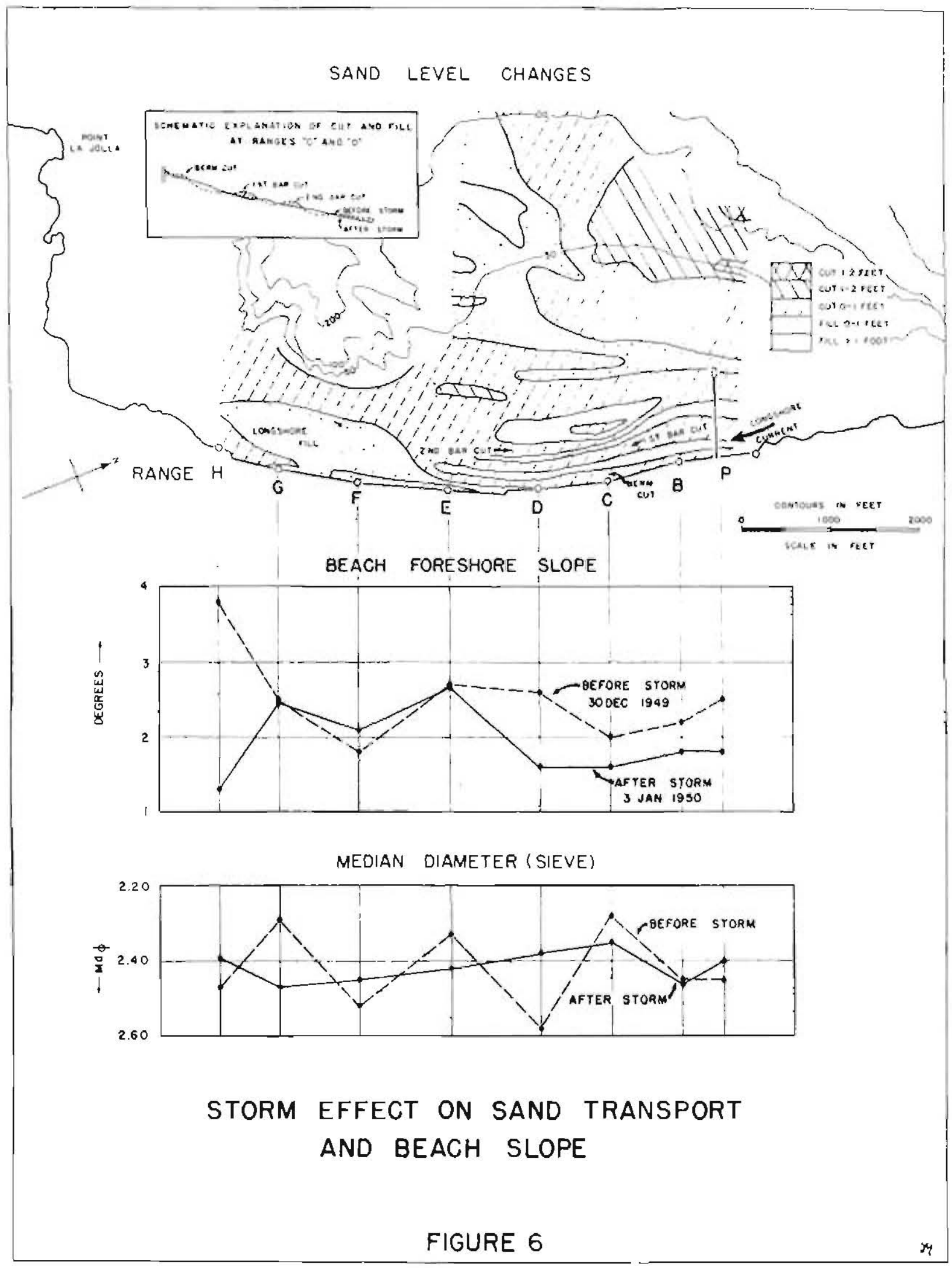




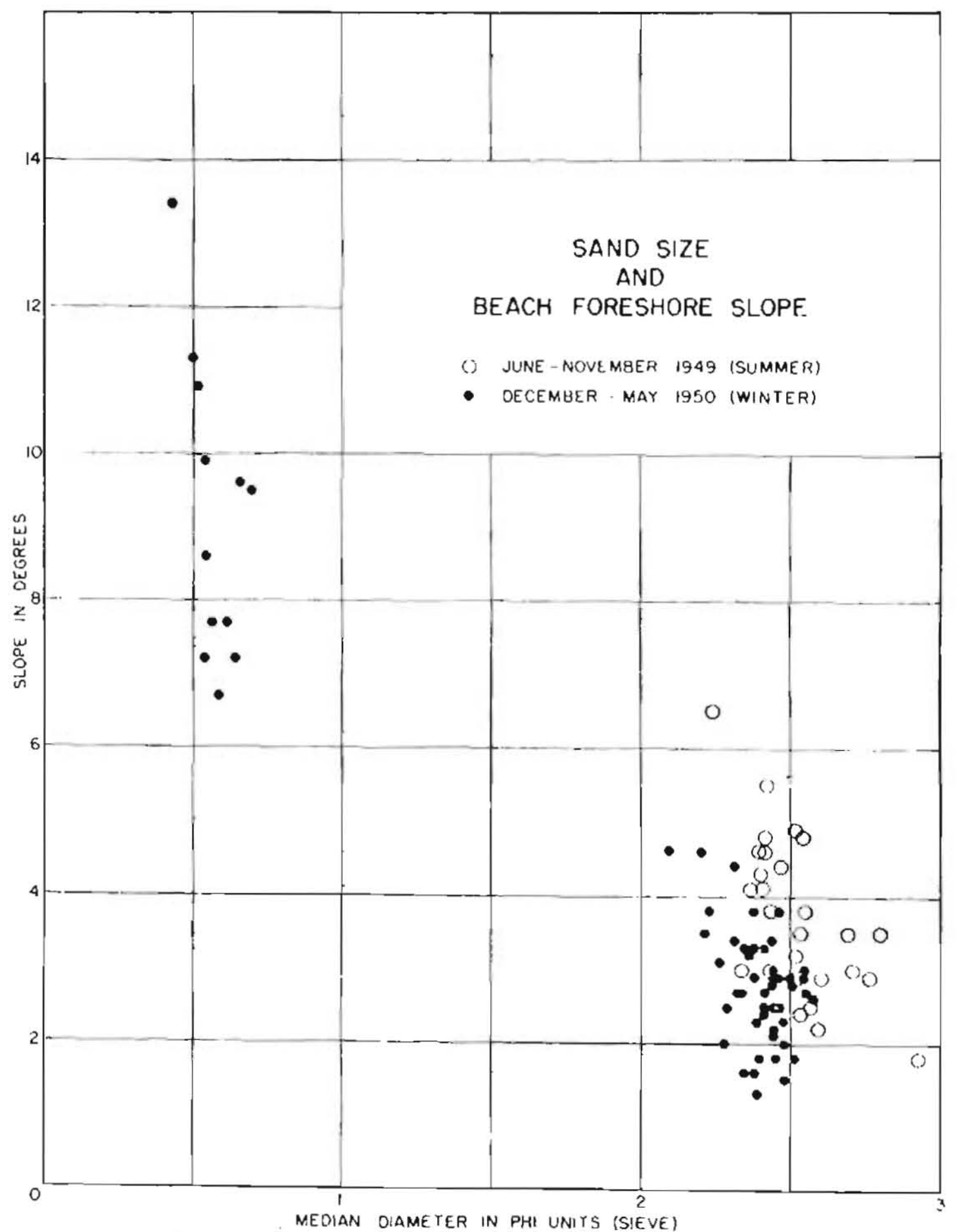

Figure 7. Reiation batween sand size and beach forestiore slope for sumier ind inter conditions. Sands with median diameters between 2 and $\hat{z}$ ini are from the receated range stations, principally along Scripe Bench, virile those ith medians butween 0 and $l$ ohi are from the supolementary stalions on the inint Li Jolla Pocket Beaches. The suonement ry stifions xere not sanpled during the sumer montins. Data for this figure ore listoris apendix III. 
Five series of sediment san ples were collected from Scripps Beach and the adjacent intercanyon shelf on dates as close as possible to the sand level surveys and along the same ranges. The sampling was performed at intervals of approximately two and one-half months, a series being taken during each of the following periods: (a) 30 June - I July 1949 (early summer), b) 24-26 August 1949 (mid-summer), (c) 17-18 November 1949 (early winter), (d) 15-16 March 1950 (late winter), (e) 9-11 May 1950 (late spring).

Each series consisted of an average of 86 samples from an area of approximately two million square yards on the beach and inter-canyon shelf along ranges $A$ through $H, P$ and $R$, with an average of twenty additional $s$ amples from ranges $I, S, U$, and $V$ situated to either side and at the heads of the canyons. The samples in these series have been designated as "repeated range samples," and their location is given by numerals preceded by a letter. The letter represents the range and the numbers indicate the distance of fshore from the base of the $r$ ange in thousands of feet. Thus D 1.50 designates a station on D range which is 1,500 feet seaward from the beach (figure 2).

As an aid in collocating the data from the analysis of the repeated samples, each series is liated in chronological order in appendices $I_{A}$ through IE, and within each series the samples are listed alphabetically by range and distance from shore. A short series taken along $D$ range in July 1951, a year after the other series, is included as appendix If.

In addition to the repeated aamples, approximately 100 supplementary samples were obtained to the north and south of the area. The supplementary sample stations are designated by letter-number symbols in which the letter indicates the general location: $l$ for the shelf around Point La Jolla, IB for the pocket beaches on the Point, LC for La Jolla Submarine Canyon, SC for Scripps Canyon, $T$ for the shelf north of Scripps Canyon, and $\mathrm{TB}$ for the beaches to the north. The station locations are shown in figures 1 and 2 and the data listed in appendix II.

\section{Field Methods}

Beach samples were obtained by pressing a glass sample jar into the surface of the sand. This method gave a uniform sample about five centimeters in diameter and four centimeters deep. Scripps Beach samples were usually taken during the sand level surveys so that the beach foreshore slope could be ascertained from the beach profile. At least one sample on each range was taken from the beach foreshore at about four or five feet above mean lower low water. This corresponds to the beach "reference zone" suggested for the standardization of beach sample locations by Bascom (1951). Sand sizes and beach foreshore slopes are listed in appendix III and plotted in figures 6 and 7.

The offshore samples were obtained with the La Fond-Dietz (1948) snapper-type bottom sampler, which retains about 200 grams of sample and 
usually does not penetrate more than about 5 centimeters into a sandy bottom. The jaws of the sampler were taped with foam rubber to insure a water-tight fit and thus avoid washing the sample on the way to the surface. The snapper-type sampler was used because the sediment study was primarily concerned with the distribution of the surface sediments.

The location of the offshore stations for the repeated range samples was determined by a system of visual ranges and cross ranges, checked occasionally by multiple sextant angles (Shepard and Inman, 195lb). The DUKW moved along the range until it neared the cross range, at which time the ongines were reversed and the DUKW maneuvered into position. The sample was obtained at the intersection of the range and cross range. The majority of the supplementary samples were taken from the research vessel, E. W. Scripps, and their position determined from multiple sextant angles between fixed shore stations.

Laboratory Procedure

Because the emphasis of the study was on particle-size distribution hydraulic or sieve size or both were determined for every sample. In addition, analyses of heavy minerals, carbonate content, mica, and roundness were made in cases where they seemed to be of most value. The general laboratory procedure was as follows.

Sandy sediments with no silt or clay content were first washed to remove salt, then dried at $60^{\circ} \mathrm{C}$, mixed with a rubber pestle and then split into several portions with a Jones-type splitter. Successively smaller splits were made with the Otto microsplit (Otto, 1937). Approximately 50 grams were set aside for grain-size analysis, and three 15 gram splits for total heavy minerals, carbonate and mica contents. In the relatively few cases where silt and clay were present, the split for grain-size analysis was wet-sieved through a $1 / 16 \mathrm{~mm}$. mesh and the fine fraction analyzed by the pipette method.

A rough measure of the amount of platey or disk-shaped material in the samples was obtained by counting the number of micaceous grains in the send-size fraction of the samples. The percentage of mica is based on counts of between 50 and 100 grains made under the binocular microscope. Most of the micaceous macerial was biotite, with minor amounts of muscovite and other platey minerals. During the mica counts the samples were subjected to a preliminary visual examination for such things as heavy minerals, shell content, organic content, and so forth.

Light and heavy mineral separations were made with bromoform, whose specific gravity was malntained between 2.82 and 2.84 . In most cases the separation was made on a split of the total sample. However, in cases where the size distributions of the individual minerals were required the sample was first sieved and the separation performed on each size fraction. The heavy minerals were mounted in Aroclor 4465 , then counted (at least 300 per size fraction), and the counts converted to weight-size percentage distribution in the general method outlined by Rittenhouse (1943). 
A measure of the carbonate content was obtained by digesting a split of the total sample in dilute ( $3 \mathrm{~N}$ ) hydrochloric acid, then filtering of the liquid and drying the welghing the insoluble residue. The percentage decrease in weight when subjected to this procedure was used as a measure of carbonate content.

Roundness of the quartz grains in selected samples was determined by a mothod of visual comparison. After sieving the sample each size fraction was split into amounts of approximately one gram with the 0tto microsplit, widely distributed on a counting tray and placed under a binocular microscope. About 60 grains were chosen at random, and compared with the ten roundness classes in Krumbein's (1947, plate I) visual roundness chart. The roundness of each grain was estimated and the average roundness of the size fraction computed. To place the measurements of the various size fractions on the same basis, each was magnified so that the grain images were approximately the same size. This method of determining roundness is very rapid, and while not as accurate as the more rigorous methods described by Wadell (1932, 1935), it appears to give reproducible results.

\section{Particle-size Analysis}

The geometric size distribution was obtained by shaking the sand size material through a nest of sieves for ten minutes with a Porter sand shaker (Braun Corp. \#57400). The Emery (1938) settling tube was used to determine the listribution of hydraulic sizes. In either case, material finer than $1 / 16 \mathrm{~mm}$. was measured by the pipette method (Krumbein and Pettijohn, 1938), which also gives data in terms of hydraulic values. The hydraulic diameter is the dlameter of a quartz sphere having the same settling velocity as a given particle in distilled water at the same temperature, and more particularly, in this report, its value is understood to be that obtained by the Emery settling tube or the pipette method. The hydraulic diameter is used in place of settling velocity because it is more readily comparable with geometric size as obtained by sieving.

If fine material was present, the test sample was soaked overnight in a peptizing solution of $.025 \mathrm{~N}$ sodium hexametaphosphate. I/ It was then Eet-sieved through a $1 / 16 \mathrm{~mm}(4 \phi)$ screen into a $1000 \mathrm{ml}$. graduate cylinder, and the size distribution of the fine fraction determined by the plpette method.

1) The peptizing agent consisted of 2.55 grams of $\left(\mathrm{NaPO}_{3}\right)_{6}$ per liter of distilled water. 
The Emery (1938) settling tube is a $164 \mathrm{~cm}$. long tube, with one end tapered and connected with a stopcock. The tube is filled with water and sand introduced at the top and allowed to settle, and the cumulative volume of material read from the graduations on the tapered end of the tuoe as a function of t1me. The detalls of the analysis procedure are given in the report by Poole, et al. (1951).

While results from the Emery settling tube are reproducible (Poole, et al., 1951), there are nevertheless inherent properties of the tube such as shape of the tapered end and method of introducing the sample, that cause the results to depart somewhat from trua settling velocities. This is borne out by the fact, as mentioned by Emery (1938), that the time for a given size of quartz grains to settle the length of the tube is less than that calculated from theory for individual grains. It is possible that this discrepancy is due to the formation of a slight density current the sample is introduced, causing the initial settling velocity to be that of the entire sample rather than of individual grains. However, the data from the tube are reproducible, the method is rapid, and, as will be shown later, the characteristics of the hydraulic-size distributions obtained with the settling tube are more meaningful in certain aspects of sedimentation than those obtained by sieving.

The combination of settling tube and pipette data into a single cumulative frequency curve, for the case of samples containing both coarse and fine material, is simplified because both anal ysts procedures give hydraullc sizes. However, separation of the sample into the two portions for settling tube and pipette analysis by wet-sieving is on a basts of geometric size. Therefore, heavy minerals slightly less than $1 / 16 \mathrm{~mm}$. in diameter which settle with the velocity of sand size quartz spheres, will be washed through the sieve and included in the silt size material for pipette analysis. Some platey material and light minerals remaining in the sand size fraction may have settling velocities in the silt range. Inconilete separation may also cause silt size particles to remain in the sand fraction.

Corrections for these discrepancies are made by adjusting the curiulative frequency curve. Particle size is expressed in the logarithmic phi scale of Krumbein (1936), where 3,4 and 5 in the $\phi$ notation (figure 8) correspond to $1 / 8,1 / 16$ and $1 / 32 \mathrm{~mm}$. respectively. Figure 9 shows a sample containing material which is $85 \frac{1}{2} \%$ coarser than $4 \phi$ by t-sieving. The settling tube data show that only $72 \%$ of the sample has hydraulic values coarser than $L \phi$, and that $13 \frac{1}{2} \%$ is finer than $4 \phi$. Interpolation of the settling tube data also shows that $4+2 \%$ was finer than $4.3 \phi$, the diameter value at which the first pipette observation was made. Since this is a cumulative percent "coarser than" curve, the value of the first plpette plot at 4.36 must be decreased by $4 \frac{1}{2} \%$.

The pipetfe method does not necessarily give a measure of the amount of material in the pipette portion that settles with hydraulic values in 


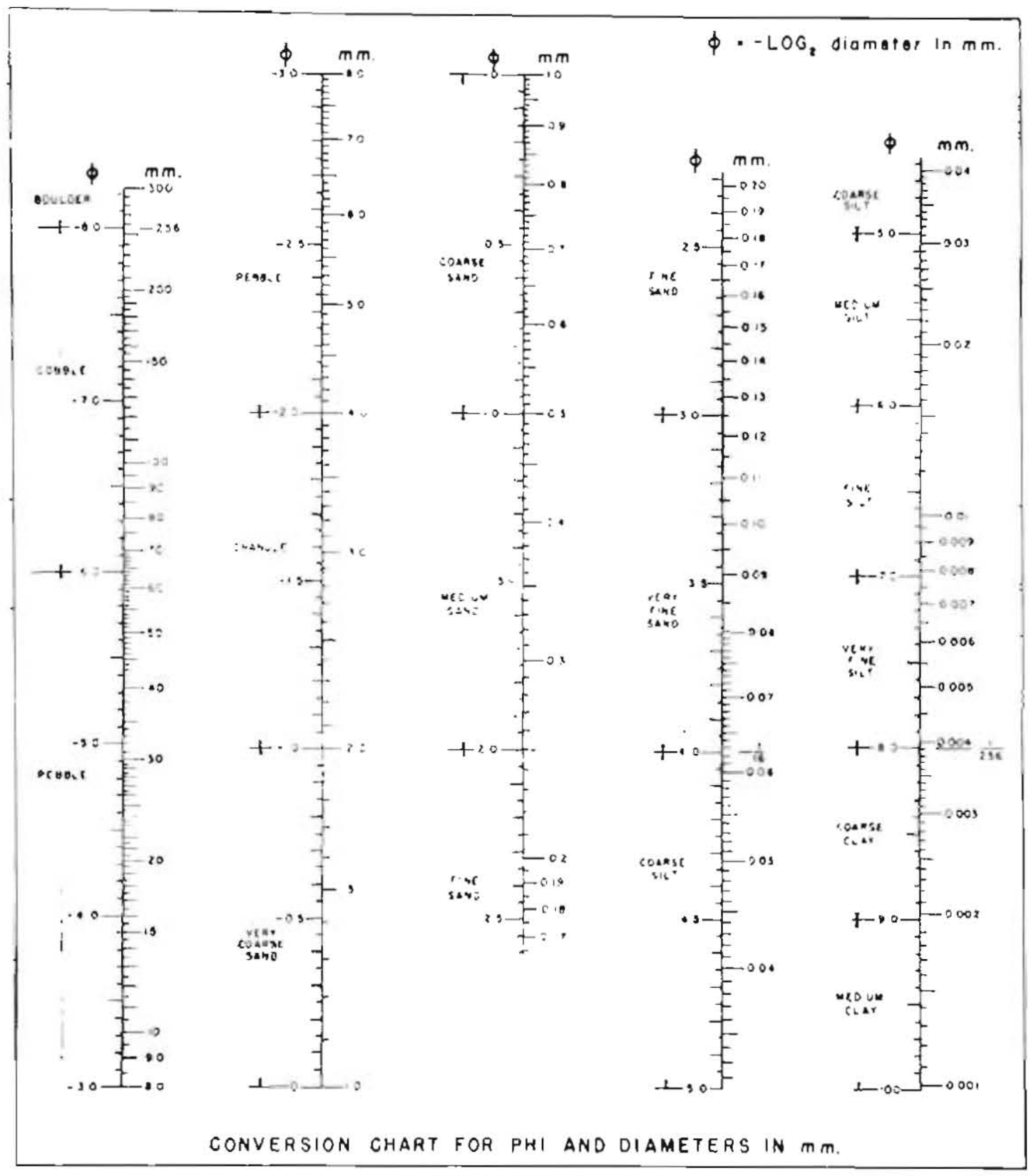

FIGURE 8 


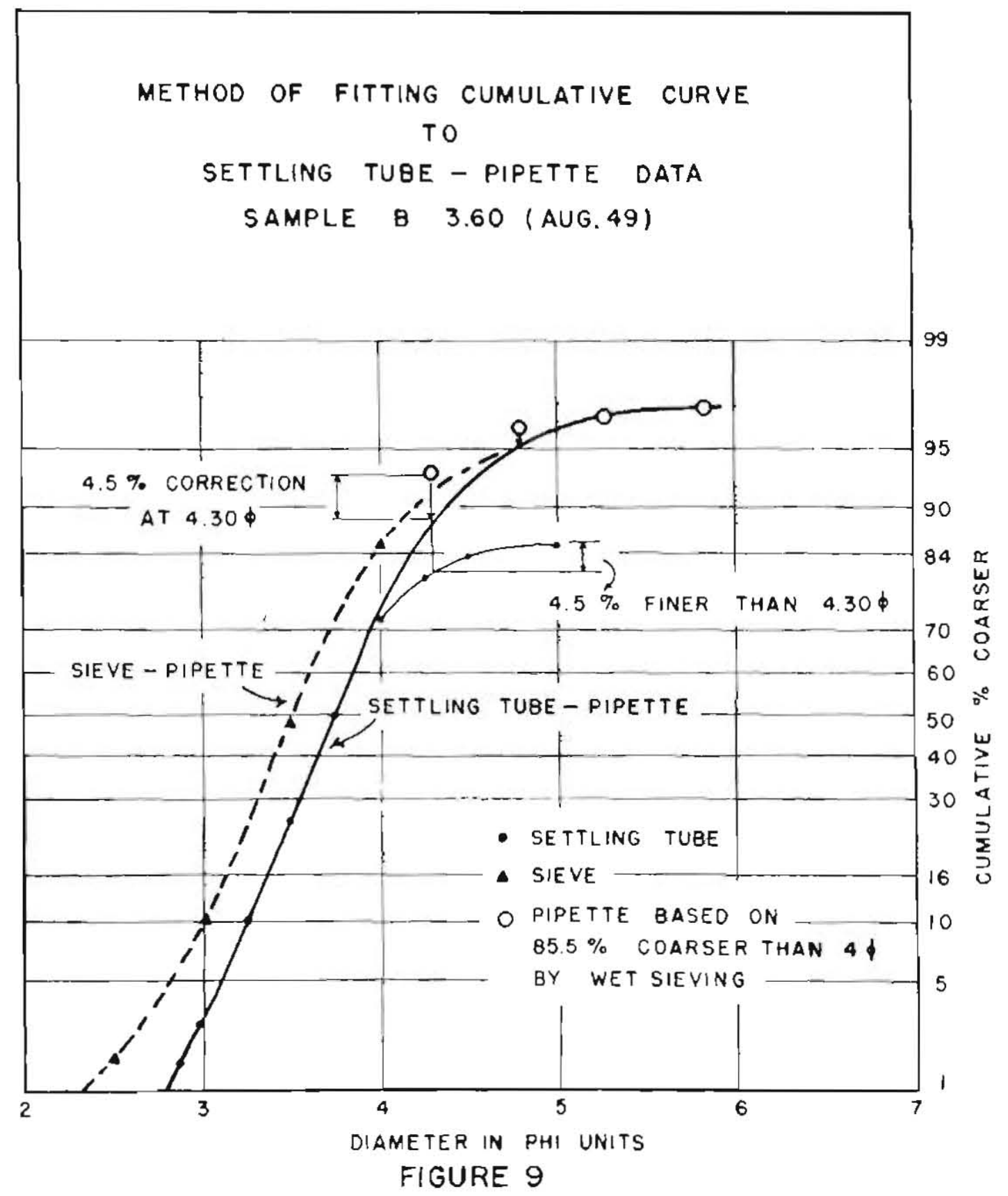


the sand fraction. Fowever, the above reasoning indicates that if heavy minerals near $4 \phi$ are present, then the settling tube plot at 4 o should be increased somewhat. As shown in figure 9 this method of fitting the cumulative curve to the combined settling tube - pipette data results in a smooth curve. Since sieve and pipette data are not compatible, no such system can be evolved for fitting curves to their combined data.

Measures of Size Distribution

Because a logarithimic diameter scale is more convenient in depicting the statistical relations of sediments, the phi notation of Krumbein (1936), where $\phi=\log _{2}$ of the diameter in millimeters, is used in this paper. $A$ conversion chart from millimeters to phi units is given in figure 8.

The results of the particle-size analysis were converted to percentages and plotted as cumulative frequency curves on arithmetic probability paper (Hazen, 1974). The particle-size distributions of the sediments were then expressed in terms of phi measures (Inman, 1952) that serve as approximate graphic analogies to the monent measures commonly employed in statistics. These parameters include a measure of the median diameter, standard deviation, kurtosis, and two measures of skewness, the second beir.g sensitive to skew properties of the "tails" of the sediment distribution. They are computed from five percentile diameters obtained from the cumulative size-frequency curve of the sediment and are defined as follows:

1. Phi median diameter, $\quad \operatorname{Md}_{\phi}=\$ 50$

2. Ph1 deviation neasure, $\sigma \phi=\frac{1}{2}\left(\phi_{84}-\phi_{16}\right)$

3. Phi skewness measure, $\alpha \phi=\frac{M_{\phi}-M_{\phi \phi}}{\sigma \phi}$

4. 2nd Phi skewness measure,

$$
a_{2 \phi}=\frac{\frac{1}{2}\left(\phi_{5}+\phi_{95}\right)-M \alpha_{\phi}}{\sigma \phi}
$$

5. Phi kurtosis measure,

$$
\beta_{\phi}=\frac{\frac{1}{\bar{c}}\left(\phi_{95}-\phi_{5}\right)-\sigma_{\phi}}{\sigma_{\phi}}
$$

where $M_{\phi}=\frac{1}{z}\left(\phi_{16}+\phi_{84}\right)$ is the phi mean diameter, and $\phi_{5}, \phi_{16}, \phi_{50}, \phi_{84}$, and $\phi_{95}$ are the diameters in phi units corresponding to the 5 th, 16 th, $50 \mathrm{th}$, 8 Lth, and 95 th percentiles respestively of a cumulative percent (coarser) curve. 
From the iive clescriptive measures it is possible to compute the five percentile diameters in the follaring manner.

$$
\begin{aligned}
& \text { 6. } \phi_{5}=1 \alpha_{\phi}-\sigma \phi+\sigma \phi\left(\alpha_{2 \phi}-\beta \phi\right) \\
& \text { 7. } \phi_{16}=1 \alpha_{\phi}-\sigma \phi+(\sigma \phi \alpha \phi) \\
& \text { 8. } \phi_{50}=1 \alpha_{\phi} \\
& \text { 9. } \phi_{84}=\alpha_{\phi}+\sigma \phi+(\sigma \phi \alpha \phi) \\
& \text { 10. } \phi_{95}=\alpha_{\phi}+\sigma \phi+\sigma \phi\left(\alpha_{2 \phi}+\beta \phi\right)
\end{aligned}
$$

The phi median diameter is a measure of central tendency. It was used in this study in preference to the mean because it may be obtained directly from the cumulative curve without interpolation and because it is less influenced by extreme values of skemess than the man. The phi deviation measure, $\sigma_{\phi}$, is a measure of sorting or spread and is approximately equal to the standard deviation of statistics (Inman, 1952). Since one phi unit is equivalent to one Nentworth division, the phi deviation measure gives the standard deviation of the curve in terms of Ventworth units.

In a symmetrical distribution the mean and the median coincide, but if the distribution is skewed the mean departs from the median, and the extent of this departure is a measure of skermess. The phi skemess, $\alpha_{\alpha}$, gives the departure of the mean from the median in terms of the phi deviation measure, and is therefore a dimensionless measure of skemess, independent of the spread or deviation of the distribution.

The phi skermess measure is zero for a symmetrical size distribution. If the distribution is skewed tomards smaller phi values (coarser diameters), the phi mean is numerically less than the median and the skewness is negative. Conversely, $\alpha_{\alpha}$, is positive for a distribution skewed towards higher phi values. This measure of skewness is related to the moment skewness, $a_{3}$, of statistics by the approximate relationship, $a_{3}=6 a_{\phi \cdot}$

The secondary skewness, $\alpha_{2 \phi}$, has the same form as the primary skewness, only it is based on the $5 \mathrm{th}$, $50 \mathrm{th}$ and $95 \mathrm{th}$ percentile diameters. While the primary skewmess is sensitive to skew properties occurring in the bulk of the particle-size distribution, the secondary skemess is most sensitive to the distribution within the tails of the sediment. Also, $\alpha_{2 \phi}$, serves as a check on the continuity of skewmess indicated by $\alpha_{\phi}$, 
and the inclusion of the second skewness, together with the other measures, allows five significant points ( $\phi_{5}, \phi_{16}, \phi_{50}, \phi_{84}$, and $\phi_{95}$ ) of the cumilative curve of a sediment distribution to be obtained from the phi measures without resort to the original mechanical analysis of the distribution.

The phi kurtosis measure, $\beta$, is a parameter sensitive to the relative lengths of the tails of adistribution compared with the spread of the central portion, and is thus a measure of peakedness. This neasure may be thought of as the ratio of the average spread in the tails of a distribution, that is the average value of $\phi_{16}-\phi_{5}$ and $\phi_{95}-\phi_{84}$, to the phi deviation measure, $\sigma_{\phi^{\bullet}}$ For a normal distribution $\beta_{\phi}$ has a value of 0.65 . If the tails have a greater spread than in the case of a normal curve, $\beta_{\phi}$ is groater than 0.65 . Conversely lower values of $\beta_{\phi}$ indicate that the tails have less spread than for a normal curve with the same deviation moasure. The linitations and the departure of the graphic phi measures from their moment equivalents is discussed by Inman (1952).

Comparison of Sieve and Settling Tube Data.

The results of the particle-size distributions obtained by sieve and Emery settling tube were compared for 144 samples. The data is listed in appendix I and II; only samples rith know amounts of heavy minerals and micaceous material sere compared. The relations between the phi median diameters and phi deviation measures are shown in figures 10 and 11 , and a summary of all the comparisons given in table 1 .

The data has been divided into several groups depending on the amounts of heavy minerals and mica, and the size of the mateial. In general, it was found that the content of heavy minerals or micaceous material must be 15:3 or more before its influence was noticeable in conparisons of sieve and settling tube data. There is a consistent tendency for the phi mean and nedian diameters obtained by settling tube to be finer (higher phi values) than those obtained by sieving, except in the case of coarse sand, where hydraulic and sieve sizes are approximately equal. The finer settling tube diameters may in part result from the non-spherical shape of the particles, because the departure is greater for samples having high amounts of micaceous material. However, in addition to shape factors, it seems likely that the difference in size is also the result of errors in calibration of the tube.

With the exception of the few coarse sand samples, the phi deviation measure, $\sigma_{\alpha}$, is less by Imery settling tube than by sieving, particularly for samples with high concentrations of heavy minerals and micaceous material. Since $\sigma_{\alpha}$ is a measure of spread or sorting, this indicates that the sediment distrlbution is more homogeneous when considered in terms of hydraulic rather than sieve size. 
TABLE 1. Comparison of Sieve and Emery Settling Tube Data. In the notation below, $\Delta M_{\phi}$ indicates the mean difference in the values of phi mean diameter obtained by sieve from that obtained by settling tube, $\triangle M_{\phi} \phi$ is the mean difference in median diameter, and so forth. Negative differences indicate that parameters obtained by sieve are algebraically greater than those by settling tube.

\begin{tabular}{|c|c|c|c|c|c|}
\hline & \multirow{2}{*}{$\begin{array}{l}\text { Number } \\
\text { of } \\
\text { Samples, } \\
N\end{array}$} & \multicolumn{4}{|c|}{$\Delta=\frac{1}{\mathrm{~N}} \sum^{\text {Mean Difference, }}$ (Tube-Sieve) } \\
\hline & & $\Delta M_{\phi}$ & $\Delta \mathbb{M d}_{\phi}$ & $\Delta \sigma_{\phi}$ & $\Delta \alpha_{\phi}$ \\
\hline $\begin{array}{l}\text { A. Samples with sieve } \\
\text { Yid between } 2 \text { and } \\
3.25 \% \text {; less than } 15 \% \\
\text { heavy minerals; less } \\
\text { than } 15 \% \text { mica. }\end{array}$ & 98 & $+.128 \phi$ & $+.150 \phi$ & $-.019 \phi$ & -.089 \\
\hline $\begin{array}{l}\text { B. Same as A, except, } \\
\text { more than } 25 \% \text { heavy } \\
\text { minerals }\end{array}$ & 26 & $+.079 \phi$ & $+.113 \phi$ & $-.051 \phi$ & -.160 \\
\hline $\begin{array}{l}\text { C. Same as A, except, } \\
\text { more than } 25 \% \text { mica }\end{array}$ & 7 & +.2466 & $+.236 \phi$ & $-.157 \phi$ & +.031 \\
\hline $\begin{array}{l}\text { D. All samples with } \\
\text { sieve lid } \phi \text { between } \\
2 \text { and } 3.2566\end{array}$ & 131 & $+.124 \phi$ & $+.148 \phi$ & $-.025 \phi$ & -.096 \\
\hline $\begin{array}{l}\text { E.All samples with } \\
\text { sieve Hd between } \\
0 \text { and } 1 \phi\end{array}$ & 13 & $-.008 \phi$ & $+.006 \phi$ & $+.062 \phi$ & -.046 \\
\hline
\end{tabular}




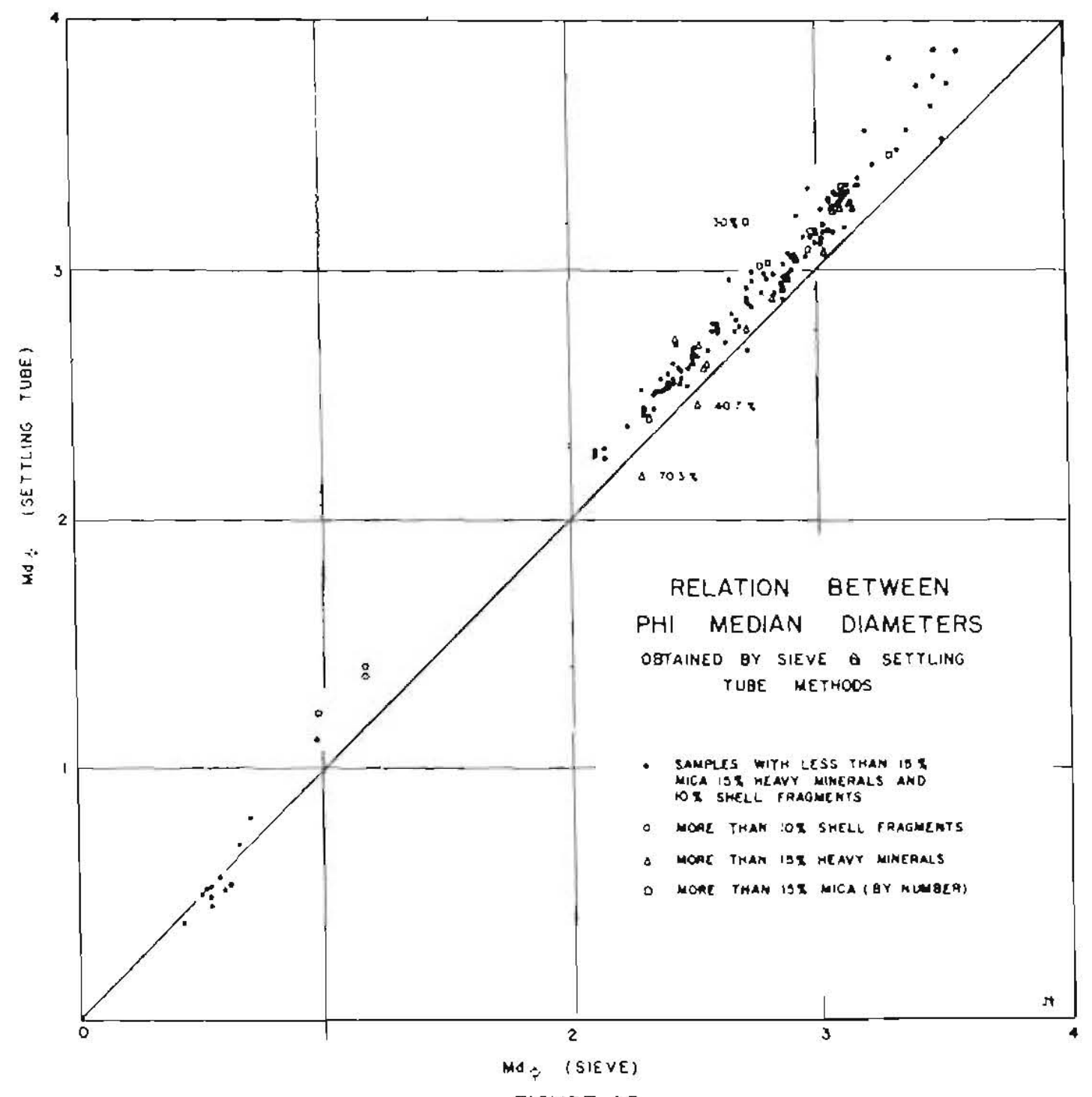

FIGURE 10 


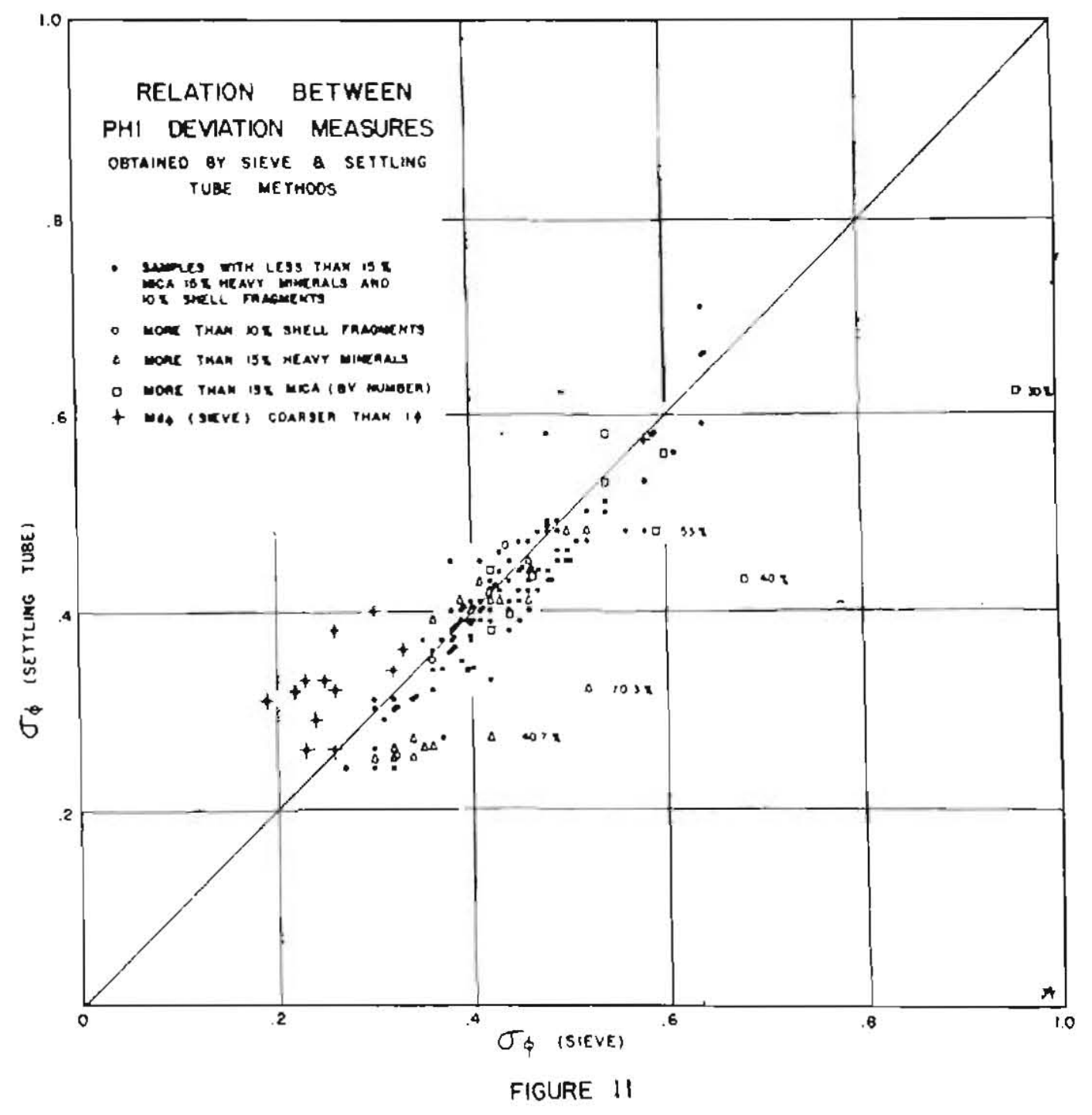


The effects of heavy and micaceous material is also shown in the phi skewness measure, $\alpha \phi$. In most cases, the distribution based on hydraulic sizes is rore symmetrical than that for sieve sizes. High percentages of heavy minerals cause the sieve distribution to be positively skewed, while micaceous material results in negative skewness. This is because heavits settle with velocities greater than their georretric size would indicate, while mica settles slower, and because the heavies are concentrated in the fine fraction of the distribution, while mica is mostly found in the coarser fractions (see figures 12 and 15).

\section{Field and Laboratory Errors}

In listing the measures for describing the particle-size distribution of a sedirent, the intention is to list parareters that represent the size distribution of the material in the bottom sediments at the time of sampling and intended location of sampling. However, there are certain errors in obtaining the sample which arise from factors such as differing homogeneity of the bottom material, depth of penetration of the sampling device, and from slight errors in positicn due to motion of the sempling vessel and depth of water. In addition, there are other errors resulting from the technique and methods of analysis of the sediment in the laboratcry. In practice it is convenient to corrbine all of the individual errors into two classes, the "field error" and the "laboratory error", which together constitute the "total error".

If numerous independent samples are taken from a single station and analyzed, it will be found that each analysis differs somewhat from the others. The best estimate of any particular measure of sand size at the locality of sampling will be the mean value of all the observations. The difference betreen any individual observation and the mean of the observations will. be the total error for that observation. In general, the errors cluster around the arithmetic mean, the number of observations decreasing with increasing distance either side of the mean value. Errors of this type tend to follow the normal distribution function, sometimes called the Gaussian law of error.

A useful measure of the reproducibility, or magnitude of error to be expected from any given analysis is the standard deviation, $\sigma$, of the errors. This is defined as

$$
\sigma=\sqrt{\frac{\sum\left(m_{i}-N_{i}\right)^{2}}{n-1}}
$$


where $M$ is the mean value of any given characteristic resulting from $n$ observations or samples, $\mathrm{m}_{i}$ is the value of each individual observation, and $n-1$ is used to give an unbiased estimate of the standard deviation in accordance with small sample theory (Hoel, 1947, p. 129). For most symmetrical distributions approximately $68 \%$ of the observations are includec between the values of $M-\sigma$ and $M+\sigma$. In terms of the e rror or reproducibility to be expected in sampling and anal $\mathrm{y}_{\mathrm{z}}$ ing sediments, this means that 68 out of every 100 measurements of any particular sediment characteristic, $m_{i}$, should fall within plus or minus of the true mean value $\mathrm{N}$.

In order to evaluate the various errors in the measures of size distribution a series of 12 bottom samples was taken at each of two stations during a 2 hour period. The first series was taken at station $\mathrm{B} 1.22$ in 23 feet of water and the second at station D2.65 at a depth of 54 feet. In order that the conditions of measurement remain the same for e ach case, the identical procedure of determining position by ranges and cross ranges, of maneuvering the DUKW into position, and sampling were carried out for each sample. The samples were treated in the general manner outlined by Krumbein (1934) for evaluating total and laboratory errors. Each sample was dried and two splits obtained. One was analyzed directly in the Emery settling tube, and the other combined with slmilar splits of other samples from the same station into a single composite sample. The composite sample for each station was then thoroughly mixed and split into twelve portions which were analyzed in the sttling tube.

The results of analyses of 12 separate samples are subject to both field and laboratory error and, therefore, the standard deviation resulting from the distribution of any particular characteristic such as the phi median diameter would be a measure of total error. On the other hand, there is no field error involved in the results of the analyses of the splits from the composite sample, since only one sample and hence only one basic population is involved if the composite is completely mixed. In this case the errors will result from laboratory procedures such as drying, splitting, and the method of analysis of the sample. Thus the composite sample provides a means of evaluating the laboratory error independently from the field error.

The total error and the laboratory error for the six measures of grainsize distribution using the Emery settling tube as the method of analysis are 1 isted in table 2. In addition to the standard deviation of the errors, the coefficient of variation, $\mathrm{C}=100 \mathrm{\sigma} / \mathrm{M}$, is also listed. This 15 a useful measure because it gives the deviation from the mean of a characteristic in terms of the percentage of the mean. For example, at station B 1.22 the mean value of the phi median diameter Md $\phi$ is 3.16 6 , and the standard deviation of the total error of the observation is $0.037 \%$, which gives a coefficient of variation of $1.2 \%$. This means that the phi median diameters of approximately two-thirds of all $\mathrm{s}$ amples collected at the station under similar conditions and analyzed under similar conditions would fall within $1.2 \%$ of the mean value of all the observations. 
TiBCE 2. Total and laboratory errors in the measuros of size distribution of samples analyzed by the imery settling, Tubo. Rased on 12 repeated samples from each station.

\begin{tabular}{|c|c|c|c|c|c|c|}
\hline & \multicolumn{6}{|c|}{$\begin{array}{l}\text { Station B } 1.22 \\
\text { Depth } 23 \text { reet }\end{array}$} \\
\hline & \multicolumn{3}{|c|}{$\begin{array}{c}\text { Analysis of } 12 \text { repeated } \\
\text { Somples }\end{array}$} & \multicolumn{3}{|c|}{$\begin{array}{c}\text { Analysis of Composite } \\
\text { Samples }\end{array}$} \\
\hline & $\begin{array}{c}\text { Sean of } \\
\text { 3amples, } \\
N\end{array}$ & \begin{tabular}{|} 
Tota \\
Stan- \\
ard \\
Devia- \\
tion, \\
J
\end{tabular} & $\begin{array}{l}\text { Error } \\
\text { Coef of } \\
\text { Vartation, } \\
C=\frac{1006}{4}\end{array}$ & $\mid \begin{array}{c}\text { Yean of } \\
\text { Compos- } \\
1 \text { tes } \\
Y\end{array}$ & $\begin{array}{c}\text { Labora } \\
\text { Stan- } \\
\text { ard } \\
\text { Devia- } \\
\text { t1on, } \\
C\end{array}$ & $\begin{array}{l}\text { Coef of } \\
\text { variation, } \\
C=\frac{1000}{M}\end{array}$ \\
\hline $\begin{array}{l}\text { Pht Mean } \\
\text { Diameter, mo }\end{array}$ & 3.116 & .0296 & $.9 \%$ & 3.126 & $.019 \phi$ & $.6 \%$ \\
\hline $\begin{array}{l}\text { Ph1 Median } \\
\text { Diameter, Md } 6\end{array}$ & 3.166 & .0376 & $1.2 \%$ & 3.166 & $.018 \phi$ & $.6 q$ \\
\hline $\begin{array}{c}\text { Phi Dovla- } \\
\text { tion Yeasure, } \\
\sigma_{\phi}\end{array}$ & .426 & $.015 \phi$ & 3.6 & $.42 \phi$ & .0056 & $1.2 \%$ \\
\hline $\begin{array}{l}\text { Phi skewness } \\
\text { Measure, c奴 }\end{array}$ & -.10 & .037 & $39.0 \%$ & -.09 & .028 & $32.2 \%$ \\
\hline $\begin{array}{l}\text { 2nd th1 skew- } \\
\text { ness Megasure, } \\
2 \not \phi\end{array}$ & -.22 & .053 & $23.6 \%$ & -.19 & .016 & $8.6 \%$ \\
\hline $\begin{array}{l}\text { Thi Kurtosis } \\
\text { Measure, } \beta_{\phi}\end{array}$ & .61 & .038 & $6.2 \%$ & .60 & .041 & $6.8 \%$ \\
\hline & & & $\begin{array}{l}\text { Station } \\
\text { Depth } 5\end{array}$ & $\begin{array}{l}i 2.65 \\
4 \text { feet }\end{array}$ & & \\
\hline $\begin{array}{l}\text { Phi Mean } \\
\text { Diameter, Mo }\end{array}$ & 3.246 & .0256 & $.8 \%$ & $3.25 \phi$ & $.023 \phi$ & $.7 \%$ \\
\hline $\begin{array}{l}\text { Phi Median } \\
\text { D1ameter, }{ }^{\prime} \mathrm{d}_{\phi}\end{array}$ & 3.306 & $.028 \phi$ & $.8 \%$ & 3.306 & .0216 & $.6 \%$ \\
\hline $\begin{array}{c}\text { Phi Vevia- } \\
\text { tion Veasure, } \\
\sigma_{\phi}\end{array}$ & .376 & $.019 \phi$ & $5.1 \%$ & .386 & .0096 & $2.4 \%$ \\
\hline $\begin{array}{l}\text { Phi Skewnoss } \\
\text { Measure, } \alpha_{\varnothing}\end{array}$ & -.16 & .037 & $24.9 \%$ & -.14 & .022 & $15.7 \%$ \\
\hline $\begin{array}{c}\text { 2nd Yhi jken- } \\
\text { ness } \\
\mathrm{X}_{2 \phi} \\
\end{array}$ & -.35 & .067 & $19.0 \%$ & -.36 & .047 & $13.2 \phi$ \\
\hline $\begin{array}{l}\text { Phi kurtosis } \\
\text { iseagure, } \beta_{6}\end{array}$ & .65 & .063 & $9.6 \%$ & .69 & .046 & $6.7 \%$ \\
\hline
\end{tabular}


In general, the total error is not the sum of independent errors such as field and laboratory errors, but rather if the various errors are uncorrelated, the square of the total error is equal to the sum of the squares of the independent errors,

$$
E=\sqrt{E_{f}^{2}+E_{1}^{2}}
$$

Thus at station B 1.22 where the coefficient of variation of the total error of the phi median diameter is $1.2 \%$ and the laboratory error is $0.6 \%$, the field error using the above equation is found to be $1.0 \%$. The coefficient of variation of total, laboratory and field errors, in the phi median diameter at station $D 2.65$ in deeper water are $0.8 \%, 0.6 \%$ and $0.5 \%$ respectively. The lower value of field error at station $D 2.65$, even though it is over twice as deep as station $B 1.22$ can be explained on a basis of the differences in gradient of median diameter along the ranges in the vicinity of the two stations. The motion of the DUKW was along the range, and hence error in sample position should also be in the direction of the range. At station $B 1.22$ the phi median changes rapidly with distance along the range, and therefore errors in position would result in relatively large errors in phi median. There is little change in phi median with distance in the vicinity of station D 2.65 (see figure $21 B-E)$.

The coefficients of variation of the laboratory errors in the determination of total heavy minerals and carbonate content were approximately 4 and 10 percent respectively. The coefficient of variation of the mica counts was 8 percent when mica composed about 5 percent of the sample. The coefficient increased somewhat for higher concentrations because mica tended to obscure and cover quartz grains, "thus making the counts less accurate.

It should be noted that the nature and scale of homogeneity of the sediment at the locality of sampling are important factors in the interpretation of sediment properties and their errors. If a sediment property such as particle size varies as a continuous function both horizontally along the bottom and with depth in the sediment, then the above analysis of sampling error can readily be applied. On the other hand suppose that the sediment is stratified in such a manner that there are sharp discontinuities, and that the strata are large compared to the width or depth of sample. In this case the property is discontinuous, the application of simple laws of probability becomes difficult, and the interpretation of such parameters as the measures of size distribution becomes obscure.

The pronounced lamination of beach foreshore sands (figure 13) indicates that beach samples are composites, and places some doubt on the nature of the vertical distribution of sediment properties. However, the laminae are small compared with the depth of sampling so that a large number are included in each sample. Also the high degree of homogeneity 
and symmetry of the hydraulic size distribution of the beach sands suggests, that while the laminae differ from one another they tend to group themselves around the mean value in accordance with the normsl distribution law.2/ These racts together with the numerous figures showing systematic areal distribution of sediment parameters indicate, with the possible exception of heavy minerals in the beach sands, that in most instances the sediment properties behave as continuous functions.

\section{DESCRIPTION AND COMPOSITION OF THE SEDIMENTS}

The sediments on the beach and intercanyon shelf are predominantly fine quartz sand with minor amounts of feldspars, and heavy minerals. Light minerals, that is those with a specific gravity of less than about 2.85 , usually comprise $90 \%$ of the sample, while heavy minerals total about $10 \%$. Of the light minerals approximately $88 \%$ is quartz, $10 \%$ feldspars and $2 \%$ shell fragments and miscellaneous material. Of the total heavy minerals hornblende is most plentiful, comprising about $60 \%$, while blotite, black opaques, epidote, sphene and garmet are also abundant.

On a basis of the hydrodynamics of particle transportation the composition of the sediments can be roughly divided into three classes; (1) light minerals, 2/ heavy minerals excluding biotite, and 3) micaceous or platey material which is almost entirely biotite. The distribution of micaceous material, heavy minerals, and carbonate content of the sedinents will be discussed separately. A summary of the seasonal changes in these components along range $D$, through the center of the area; is given in figure 18 near the end of this section. The percentage of micaceous material, heavy minerals and carbonate content, when determined are listed with the particle-size distribution of the sample in appendices I and II.

\section{Heavy Minerals}

The total amount of heavy minerals varied from 1.7 to $45.0 \%$ in the sediments from the beach and intercanyon shelf, while the coarse sands from the Point La Jolla pocket beaches commonly contained less than $1 \%$ and one sample from the beach north of Scripps (TB-3), obtained during the winter season, had more than $70 \%$ heavy minerals.

The weight-size distributions of four comnon minerals, green hornblende, epidote, sphene, and garnet, for selected samples are given in table 3. Less abundant mineral species are listed in the footnote to this table. The cumulative frequency curves of the mineral species for the beach foreshore sample (figure 12) show that the median for each specie is displaced toward the fine sizes in accordance with its specific gravity. This tendency was observed in other samples, al though there were occasional reversals.

2/ A microscopical study of thin-sections of laminated beach sand by Emery and Stevenson (1950) Indicates that median diameters of individual laminae tended to group themselves around the mean value in accordance with normal law theory. 


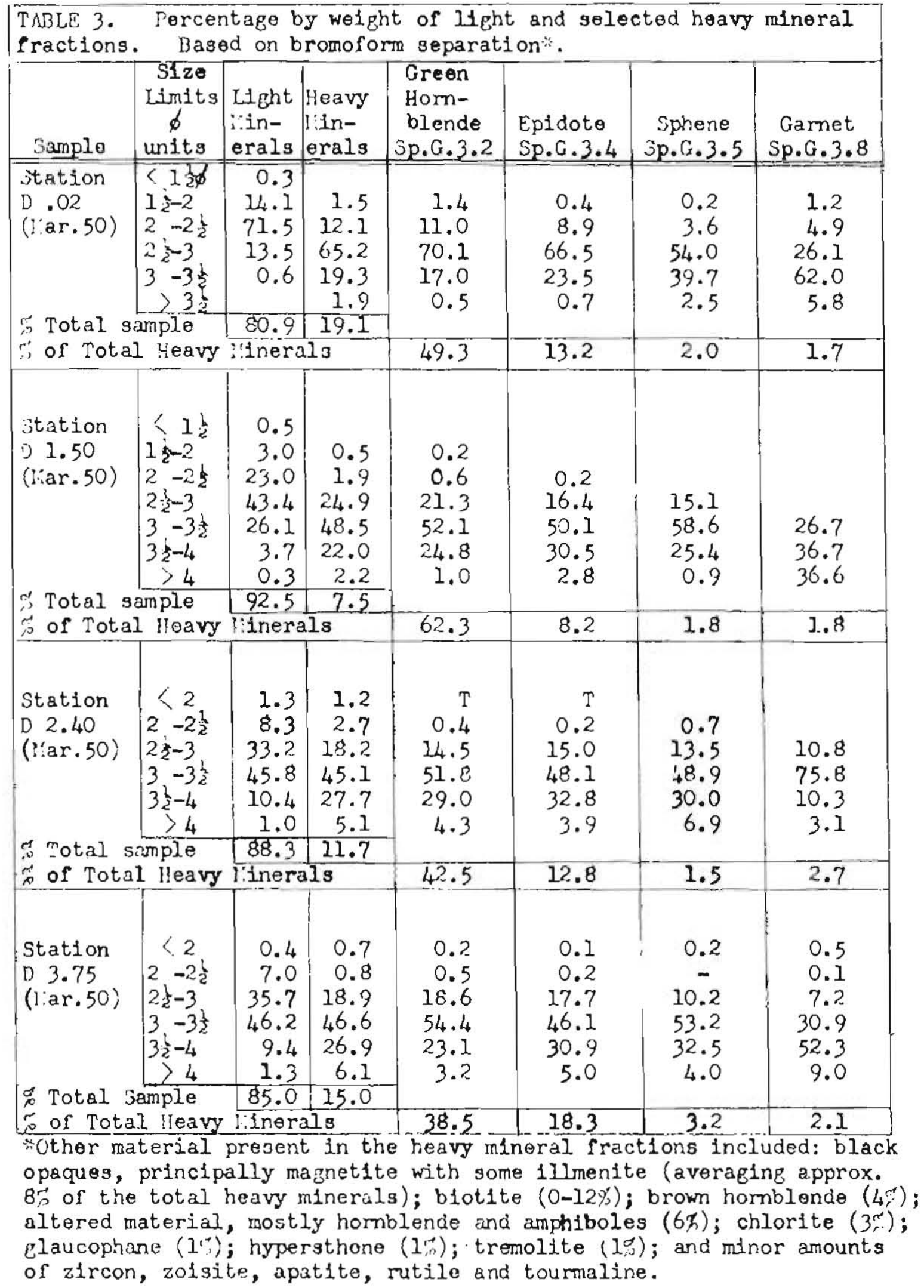


CUMULATIVE CURVES OF A

TYPICAL BEACH FORESHORE SAMPLE

WITH SELECTED HEAVY MINERALS

TYPE I, STATION D.O2 (MAR. 5O)

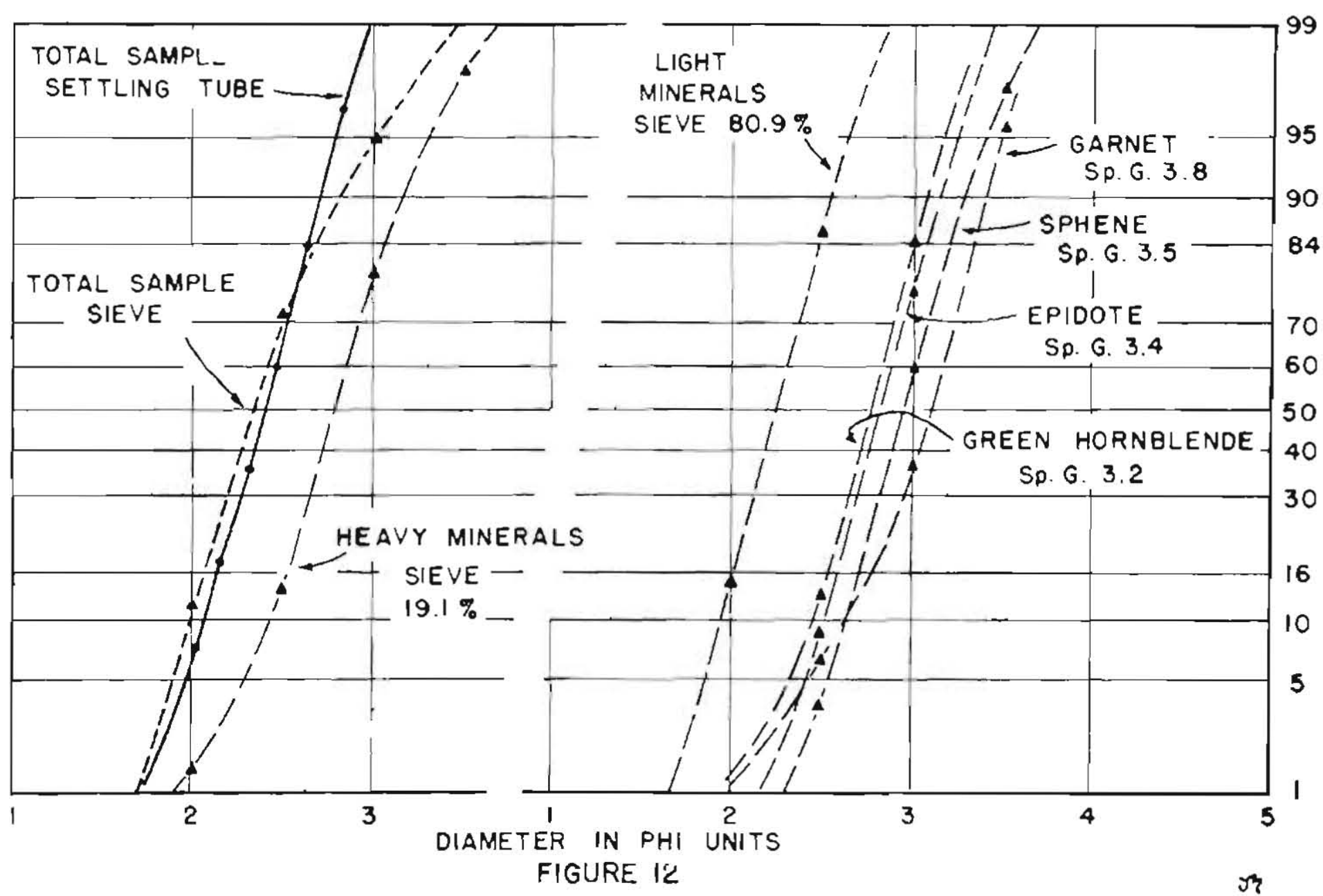

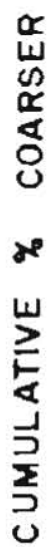




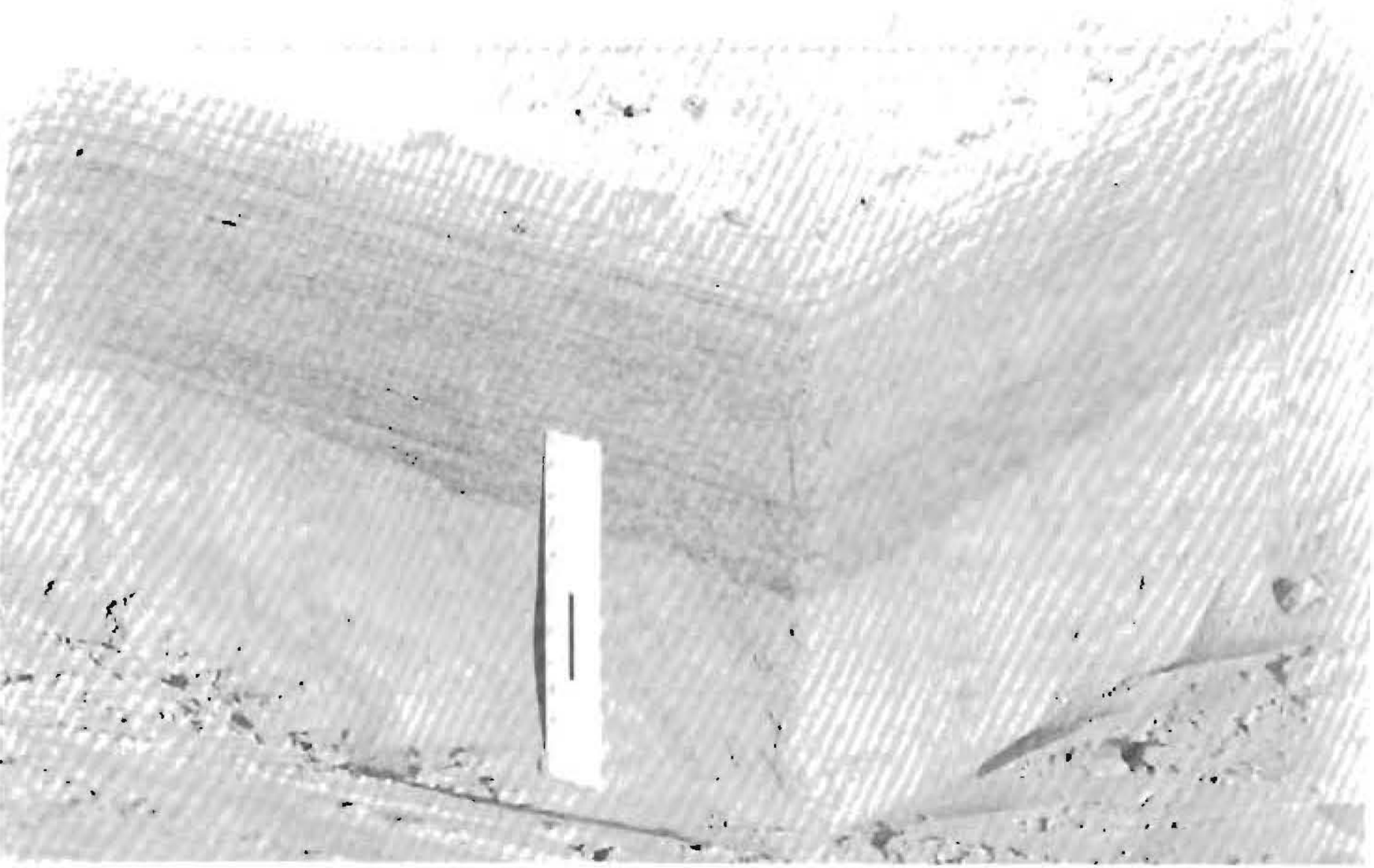

Figure 13. Lamination in the beach foreshore at station 8 during beginning of the winter cycle of beach cut. Biack leminae ire oredominantly heavy minerals and light are quartz. The five inch thick zone of heavy mineral laminations probably represents concentration of heavy minerals by wave action followed by deoosition during a period of neap tides. Main concentration of heavy minerals was one foot below rulo. 
There is some correlation between the heavy mineral content and the median grain-size of the total sample, sediments with sieve medians near 3.0 phi usually have the greatest amounts, while the abundance of heavy minerals decreases for coarser and finer sediments. However, location and season appear to be as important as size in determining the concentration of heavies. The greatest percentages occur on the beach foreshore, and the least amounts in the adjacent surf zone. Another band of heavy-rich sediments occurs just outside of and parallel to the surf zone (figure 14).

There is a pronounced seasonal variation in the amount of heavy minerals in the beach and nearshore samples. During the winter when the beaches are cut back, the heavy mineral content of the beach foreshore samples increases appreciably over normal summer conditions. At the same time, the heavy content of the sands outside of the surf zone is reduced. A possible explanation for this apparent seasonal migration of heavy minerals lies in the transportation of light minerals from the beach foreshore to deeper water during the winter and back again during the sumner. Since only surface samples were used in this study, deposition of light minerals results in apparent decrease in heavy mineral concentrations, and vice versa. This contention is strengthened by the relatively low heavy mineral content of the beach sands obtained at station $D$ in August. During the two months preceding the August survey this area received between two and three feet of fill, whereas the adjacent portions of the beach where heavy minerals were more abundant recelved liztle or no fill (rigure 5).

The extreme variability in the amount of heavy minerals both with location on the beach and with time raises some question as to the interpretation of heavy mineral suites in beach and nearshore studies. These facts together with the common occurrence of alternate zones and laminae of heavy and light minerals in the beach foreshore (figure 13) indicate that no simple relationship exists between the kind and amount of any particular mineral specie and its position on the beach.

\section{Distribution of Micaceous Material}

The mica content of the sediments averages about 3 percent by weight, and ranges from less than 1 percent in the surf zone to a few isolated areas where it is present in excess of $40 \%$ of the total sample. The distribution of mica in a sample from such a mica-rich area (station $\mathrm{E} 2.00$ ) is shown in figure 15. Mica is characteristically most abundant in the coarse size-fractions when separated by sieving, but exhibits greater homogeneity with the distribution of the remaining sediment components when analyzed on a basis of settling velocity.

Mica, because of its pronounced platey or disk-like shape has by far the lowest settling velocity for its size of the various sediment components. Even though it has a specific gravity of 2.9 , it is easily maintained in suspension, and therefore responds readily to both advection and diffusion processes. For this reason and because it usually comprises 

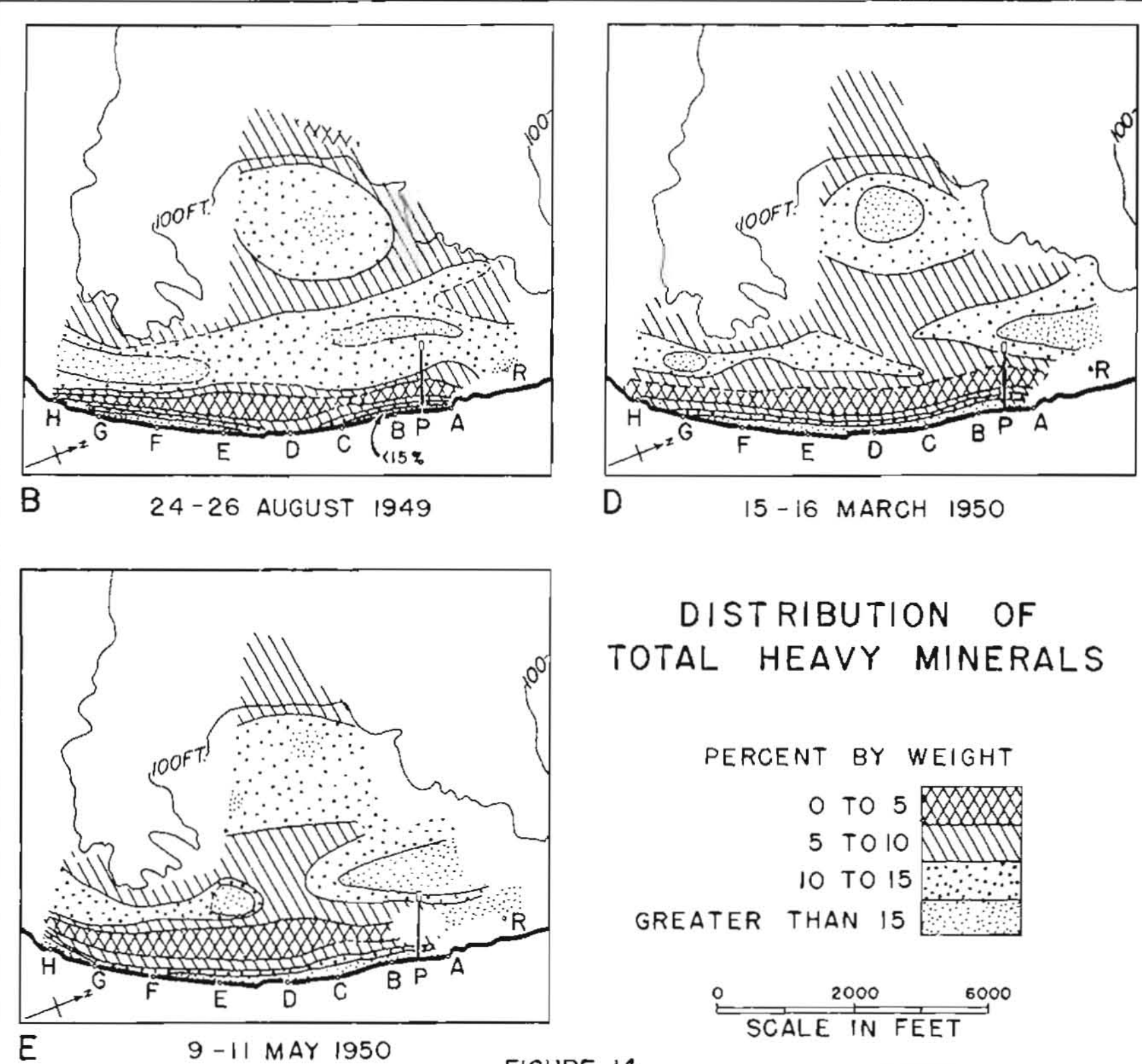

DISTRIBUTION OF TOTAL HEAVY MINERALS

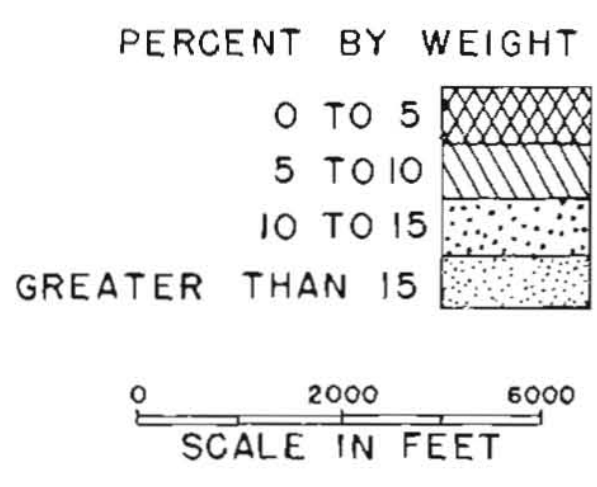

FIGURE 14 


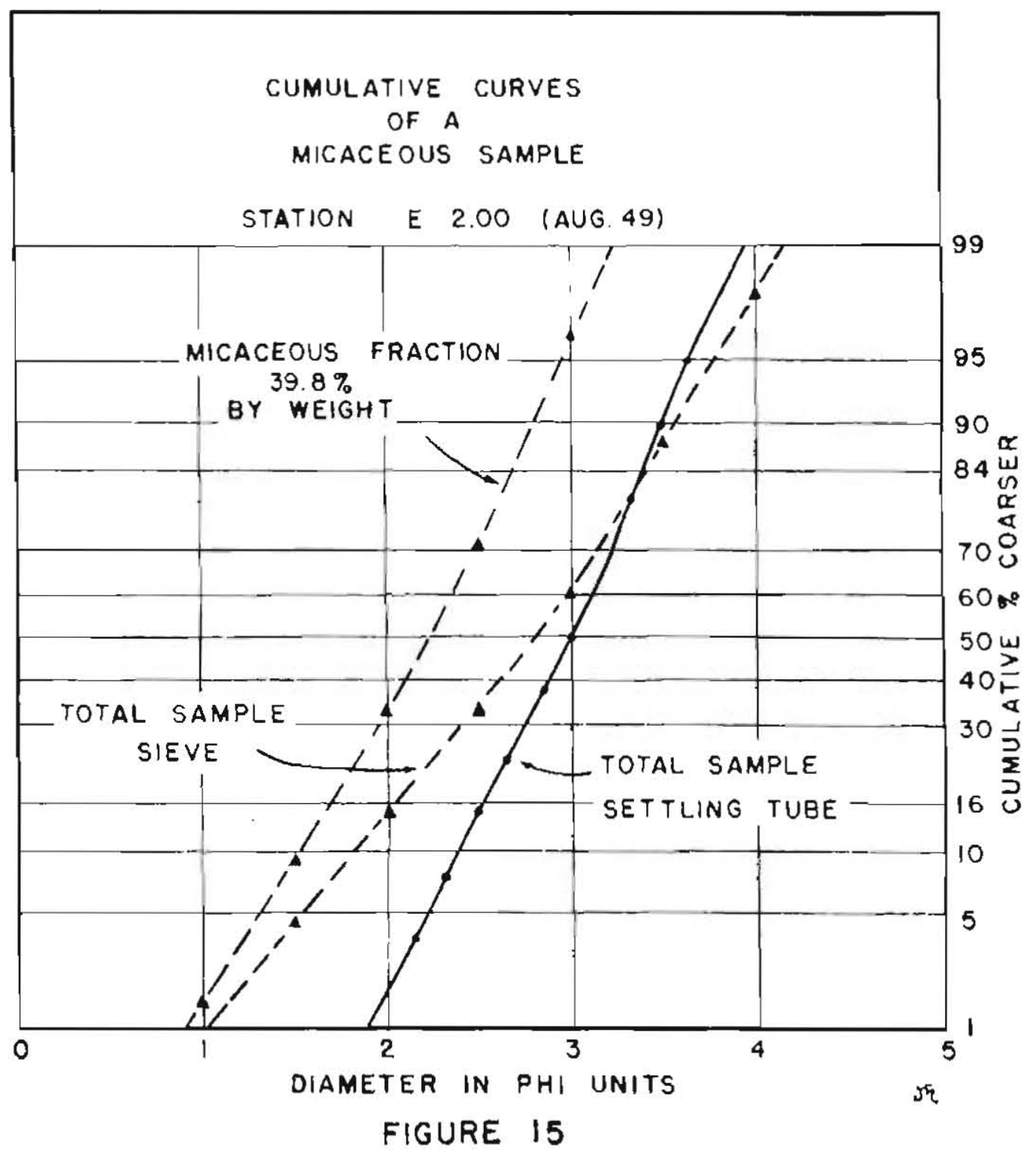


a small portion of the total sediment, it may be a more sensitive index to turbulence and water circulation than the sediment as a whole.

The distribution of micaceous material for each survey is shown in figures 16A-E. In general there is a higher percentage of mica in the bottom sediments near the caryon heads where the water is less turbulent, and a lower amount in the bottom sediments in the surf zone where turbulence is high. There is also a band of mica-rich sediments on the shelf between depths of about 20 and 50 feet which is probably the result of the nearshore circulation of water, which for long period waves is towarid shore near the wave convergence and offshore in the rip zones to either side (see figure 4). The sesward movement of water in the region of $w$ ave convergence is indicated by the tendency for mica-rich sediments to extend shoreward through the surf zone at the convergence. This tendency is most pronounced in the June, August and May samples near beach station $D$ (figure 16, A, B and E).

The last four surveys show an area of very low mica content centered on $\mathrm{D}$ range at depths between 60 and $90 \mathrm{feet}$. Also, the sediments in this area are coarser, have higher percentages of heavy minerals, and lower carbonate concentrations than sediments in adjacent areas. These anomalies may indicate that tinis area receives greater energy and is more turbulent than is normal for comparable depths elsewhere in this area. This problem will be discussed in the conclustons.

Although the pattern of the mica distribution changes somewhat throughout the year, the amount and extent of mica on the beach and in the surf zone apparently exhibit seasonal characteristics. During the winter there is a tendency for a wide band of mica-poor sediments to exist along the beach (figure 16, $D$ and $E$ ), while summer and fall surveys showed a greater concentration of mica near the beach.

\section{Carbonate Content}

The carbonate content of the sediments from Scripps Beach and the intercanyon shelf is usually low, averaging about $1 \frac{1}{2}{ }^{2}$ by weight for the August 1949 repeated range samples (see figure 17). The highest concentrations are commonly found in the $s$ urf zone where shell fragments are most numerous. A maximum of $9 \%$ carbonate was observed in the surf zone on $D$ range during the November survey. The seasonal variations in carbonate content are not as pronounced as in the case of heavy minerals and mica.

The coarse sediments from the shelf around Point La Jolla generally contain higher percentages of carbonate, the average of four samples being $11 \%$. However, nine analyses of the coarse sand from the Point la Jolla pocket beaches gave an average of $2.3 \%$ carbonate, which is approximately the same as the average for the fine sand samples from the foreshore at Scripps Beach. 


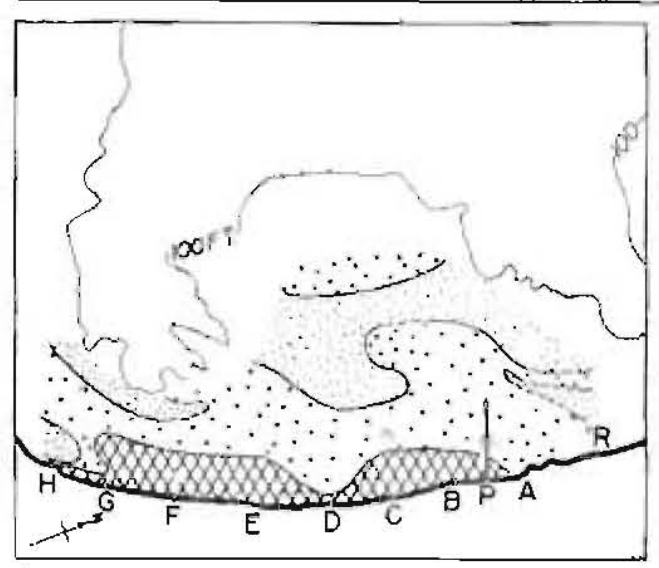

A 30 JUNE - I JULY 1949

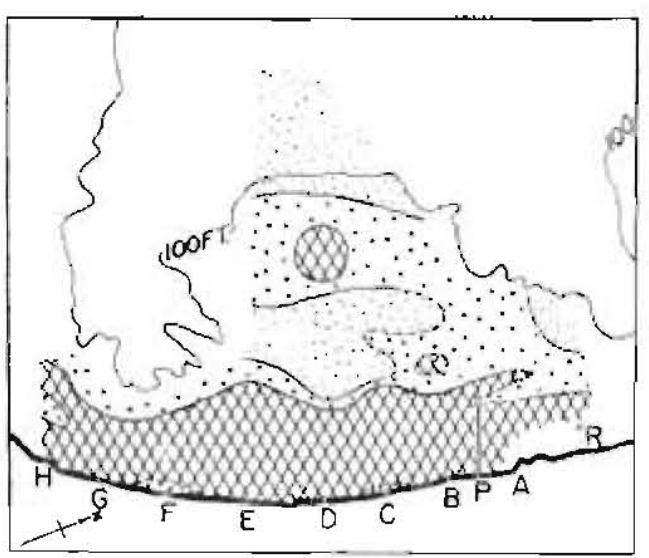

$15-16$ MARCH 1950

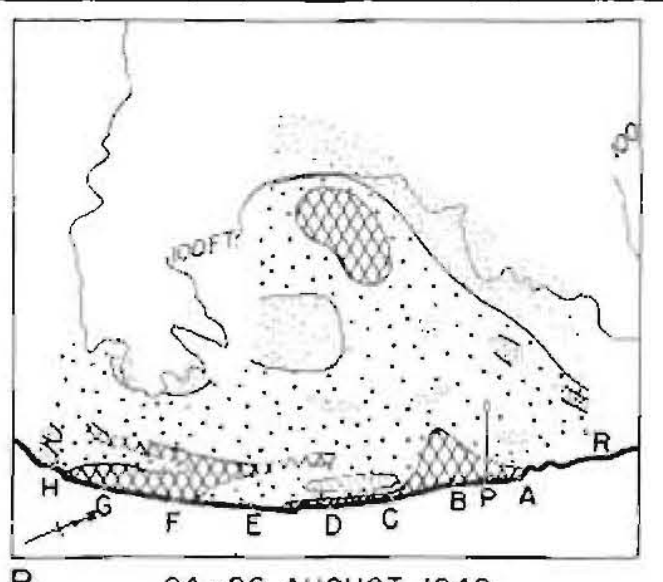

24-26 AUGUST 1949

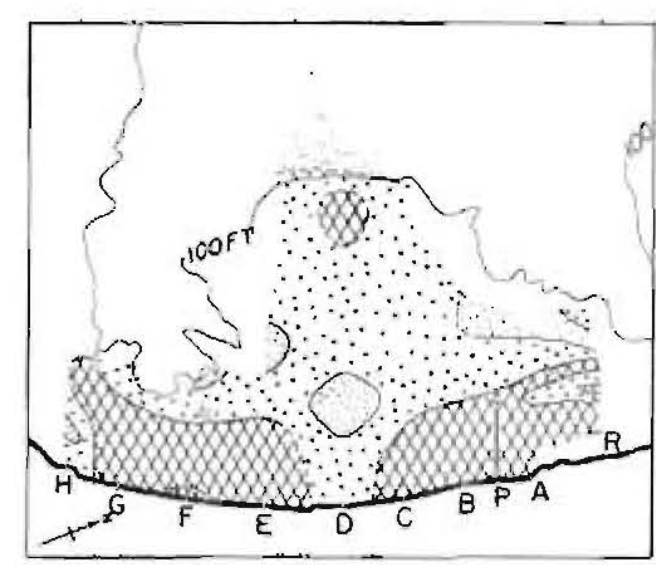

9-11 MAY 1950

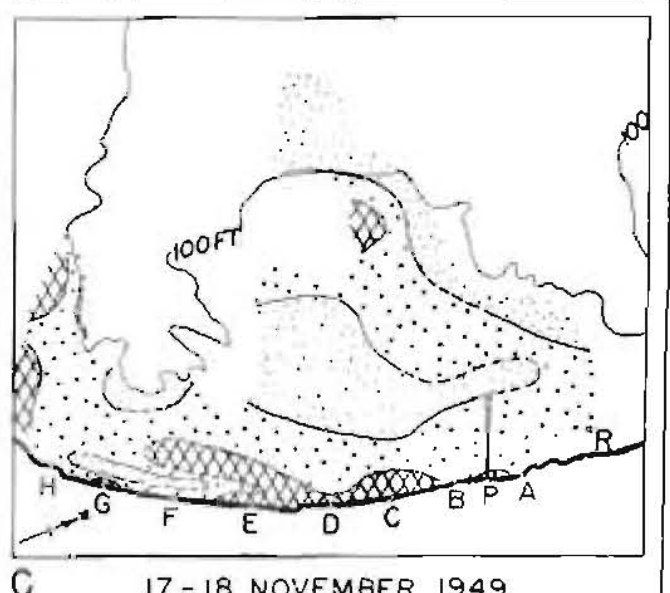

$17-18$ NOVEMBER 1949

\section{DISTRIBUTION OF MICACEOUS} MATERIAL

PERCENT BY NUMEER OF MICA GRAINS IN SANO SIZE FRACTION OF BOTTOM SAMPLES

$$
\begin{array}{r}
\text { LESS THAN } 1 \frac{1}{2} \% \text { WXXXXX } \\
1 \frac{1}{2} 3-4 \frac{1}{2} \% \because \because \cdots \\
\text { GREATER THAN } 4 \frac{1}{2} \%[
\end{array}
$$

$$
\text { SCALE IN FEET }
$$

Figure 16. hreal distribution of micaceous material for the June, August, November, March and May surveys. Mica, because of its pronounced platey shape, has a relatively low settling velocity and therefore responds readily to both advection and diffusion processes. In general, the mica content is low on the beach and in the surf zone where wave turbulence is pronounced, and high in areas where the water is less turbulent. Seaward movenent of water in the region of wave convergence is indicated by the tendency for mica-rich sediments to extend shoreward through the surf zone at the wave convergence during the June, August and May surveys. Compare with circulation pattern in Figure 4 . 


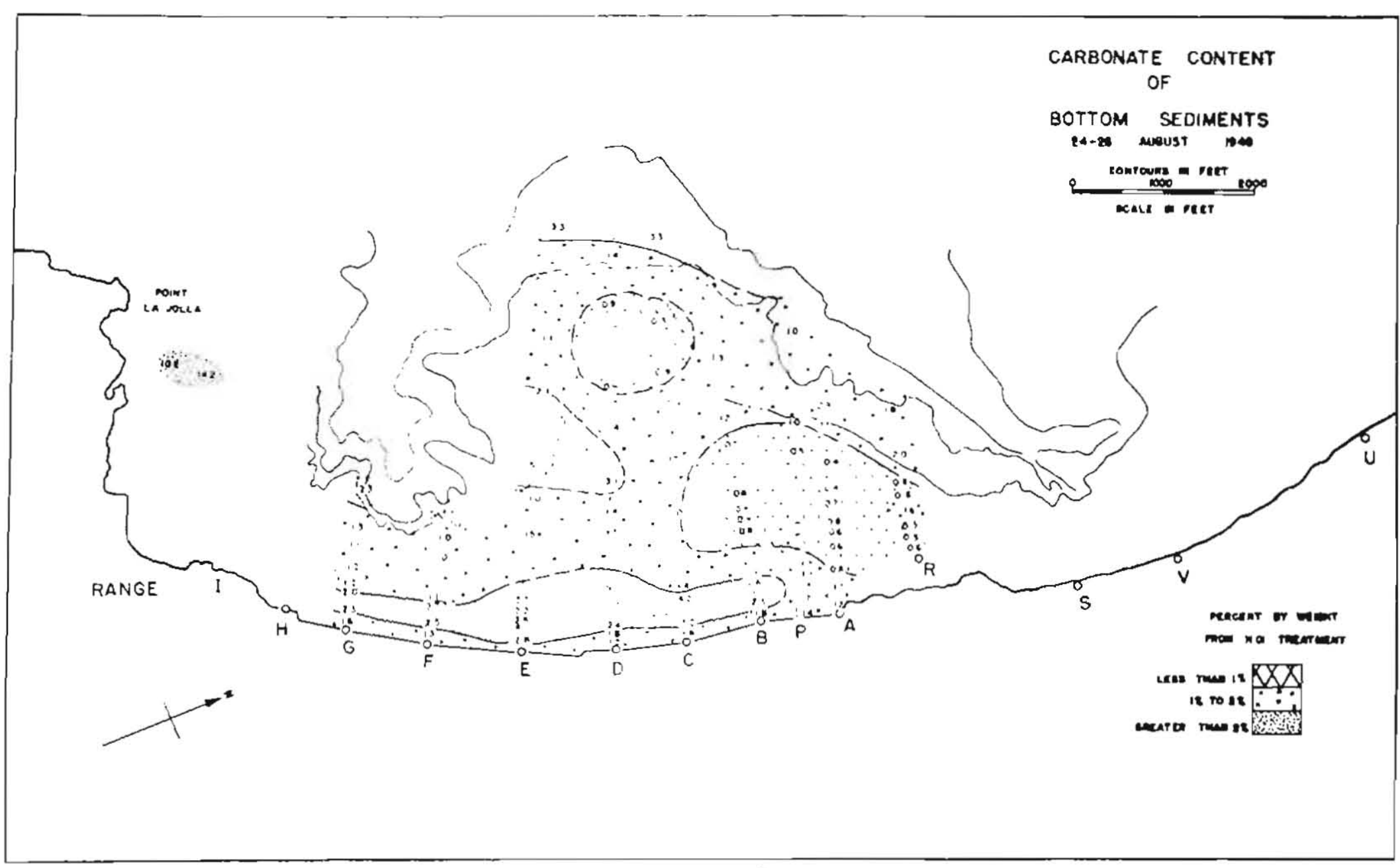

FIGURE 17 


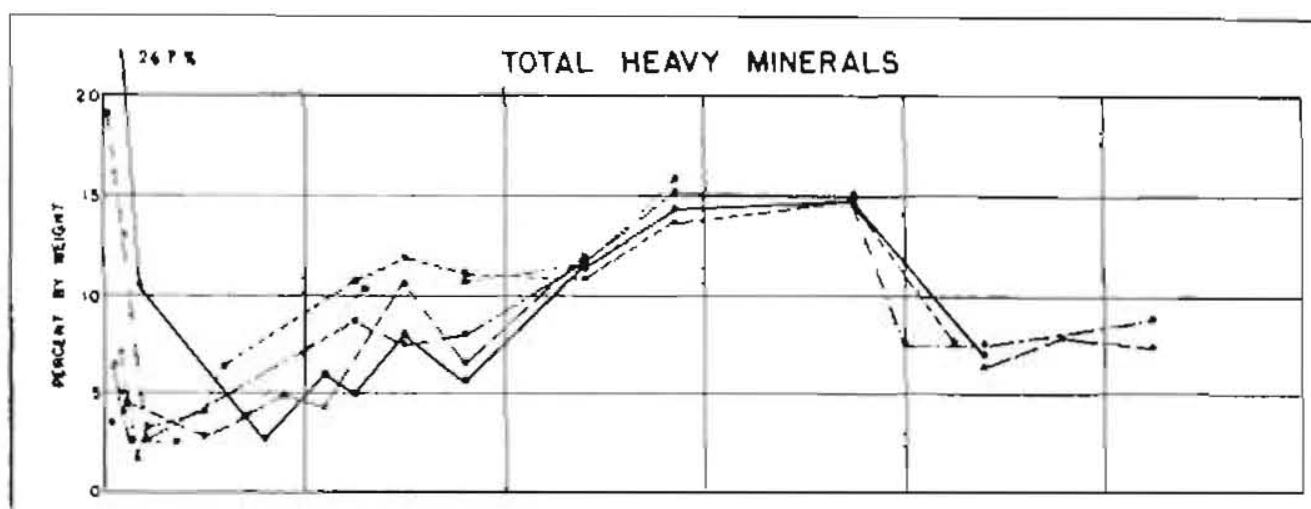

MICACEOUS MATERIAL

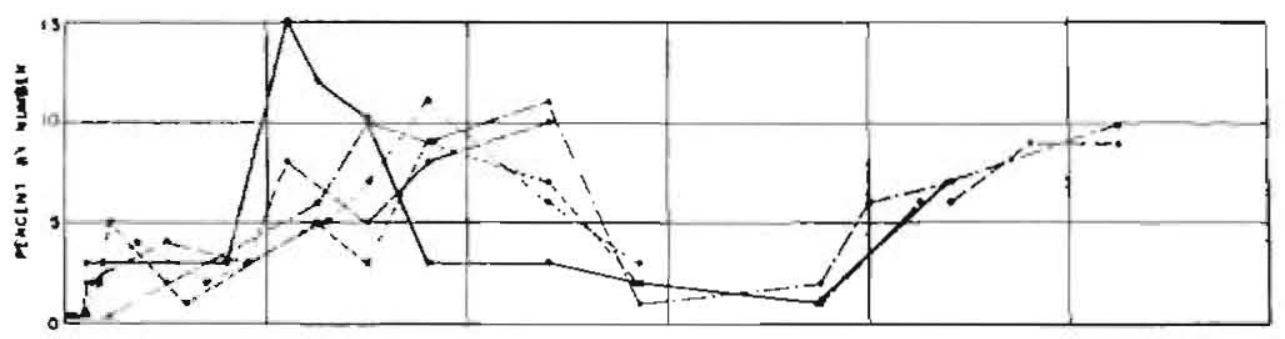

CARBONATE
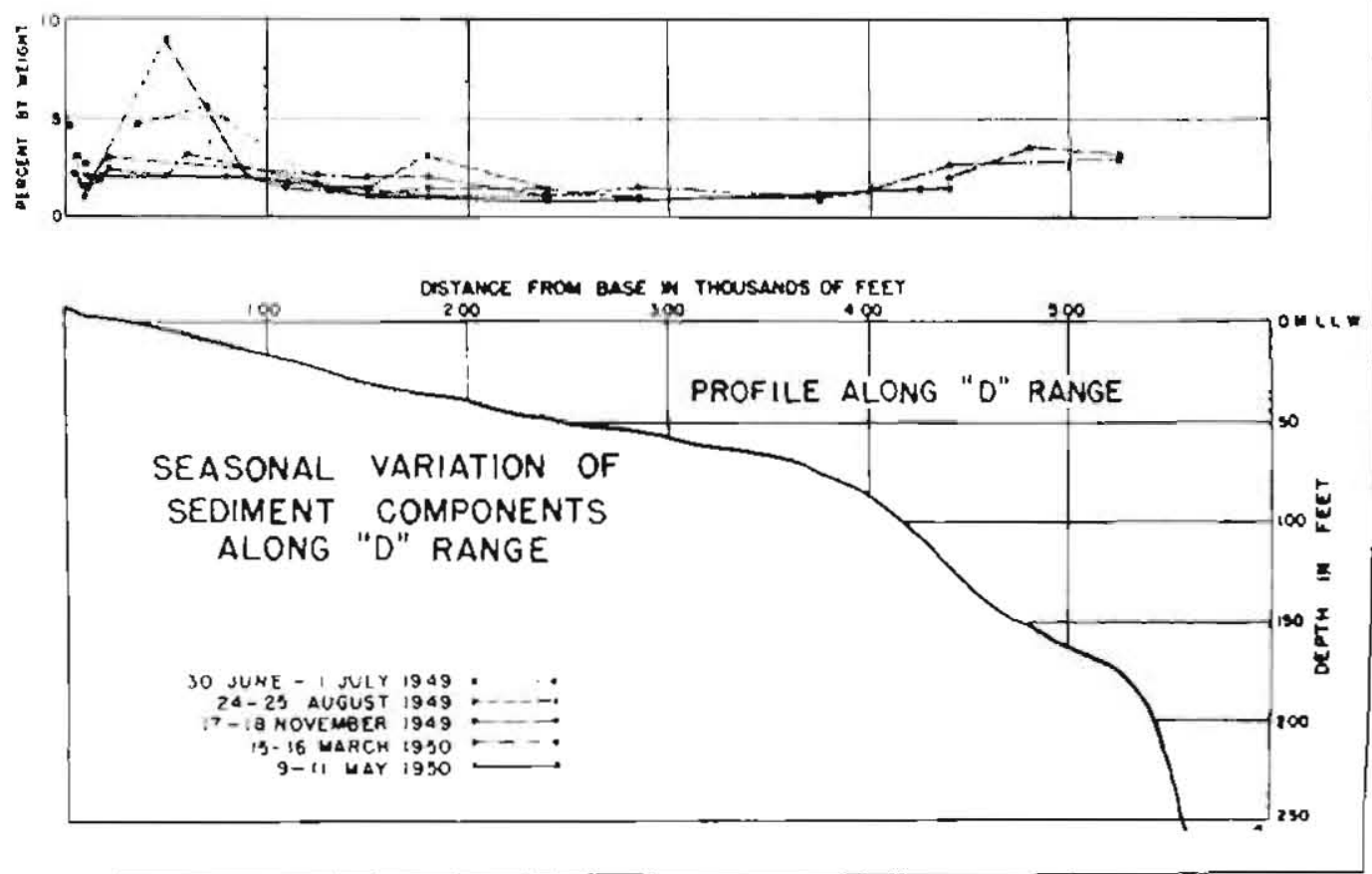

FIGURE 18 
Figure 19. Relation between roundnsss and size of quartz grains. The degreo of rounding, incresses with increasing roundness numbur. Samples in order of increasing roundness at $1 / 2 \phi$ are as follo's: from Torrey Pines Beach, TB-7, TB-2, TB-1, TB-5 and TB-4; Irom Scripos beach and shelf, D 1.25, D 1.80, D 3.75, D 1.50 and D .22, 2.1 from the Horch 1950 survey; and from the

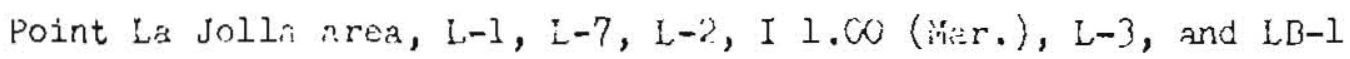
(July)。 Saroles with incorplete data are TB-l? and D 4.CO (Nar.)。 Station locations 3 re show in figures 1 and 2 . 


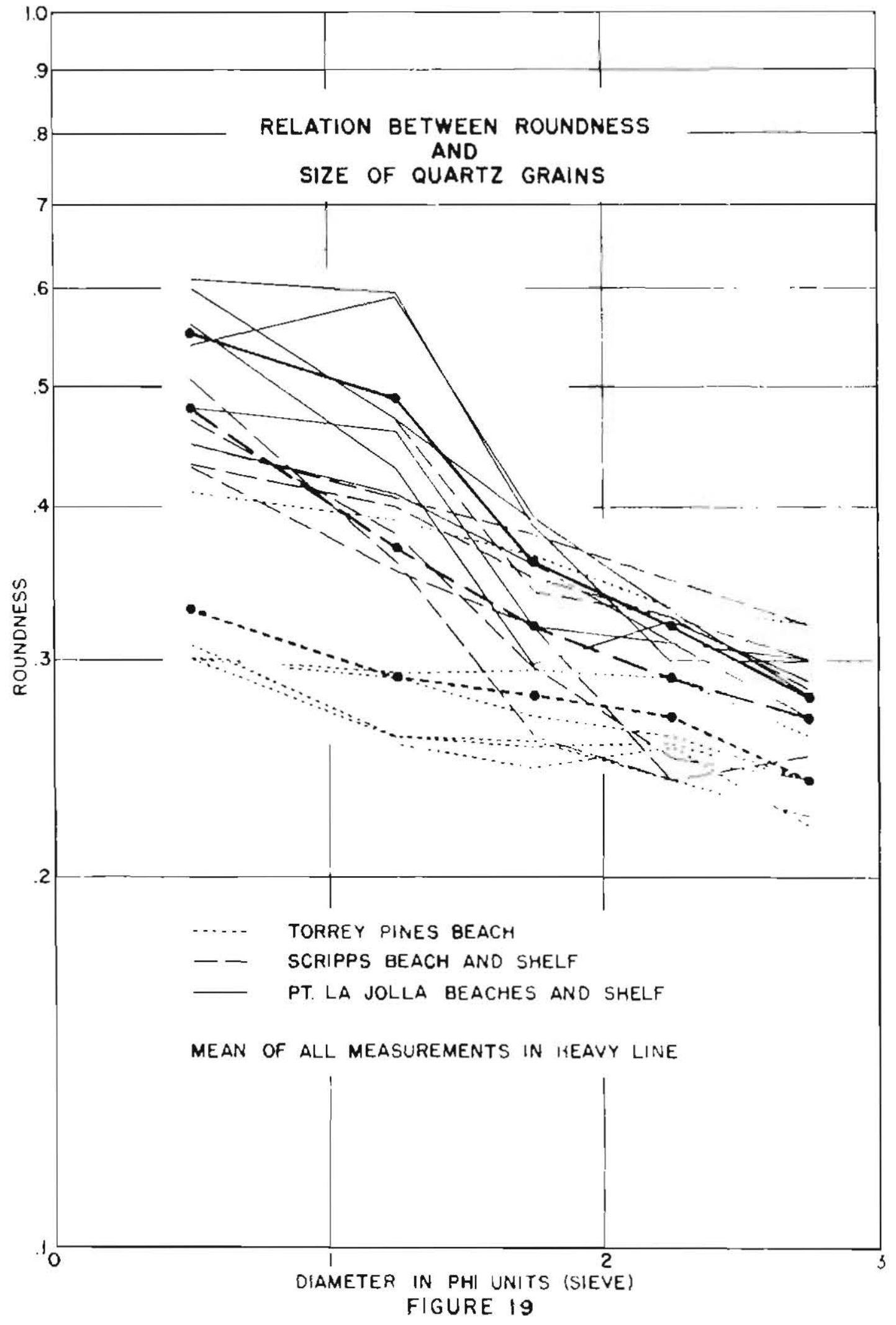


Roundness

The roundness of quartz grains in selected samples from Scripps beach and intercanyon shelf is compared with that of samples from Point La Jolla beach and shelf to the south and Torrey Pines Beach to the north in Figure 19. Houndness was determined for intervals of $\frac{1}{2}$ phi unit, using the visual roundness chart developed by Krumbein (1947). The mean value of all roundness counts for each of the three areas is shown in heavy line. The means are based on about 300 counts for each size fraction.

The mean values of the samples show that roundness improves from Torrey Pines Beach to Scripps Beach and is best in the Point La Jolla area. If roundness is indicative of the abrasion history of sands, as is commonly thought, the incresse in roundness toward the south strengthens the supposition of net southerly drift of material in this region. However, the scatter in the degree of roundness for the various samples and the fact that roundness does not show a progressive change from north to south suggests that roundness of individual samples is not necessarily diagnostic.

\section{PARTICLE-SIZE DISTRIBUTION}

In general it was found that the sediments could be divided into types on a basis of particle-size distribution, and that these types were characteristic of the environment of deposition. This was particularly true for the repeated range samples from Scripps Beach and the intercanyon shelf where the close spacing and large number of samples gave assurance that the size distributions followed certain patterns that could be correlated with environment. However, the supplementary samples from the adjacent areas, wile appearing to follow similar patterns, were not as closely spaced, as numerous, and were not sampled seasonally, so that no such assurance of correlation could be claimed. For this reason the sediment types discussed below and listed in appendices I and II, pertatn primarily to the environment or locality of deposition, rather than to the size distribution of the sediment, al though both factors were considered in the selection of types. The degree to which these environmental types fit into diagnostic size distribution patterns will be discussed below.

The sediments on Scripps Beach and intercanyon shelf are crouped into three general types (figures 20 and 27). Type I consists of beach -oreshore sands, which are the best sorted sediments in the La Jolla area. Sands from the surf zone are designated as Type IIa, and are characteristically coarser and more poorly sorted (higher $\sigma \phi$ values) than sediments farther inshore or offshore. These grade into Type IIb which are found on the relatively flat portions of the shelf from the surf zone out to depths of approximately 100 feet, and a re therefore the most abizhdant sediment on the intercanyon shelf. Type IIb sediments are predominantly well sorted, very fine sands, with less than about 


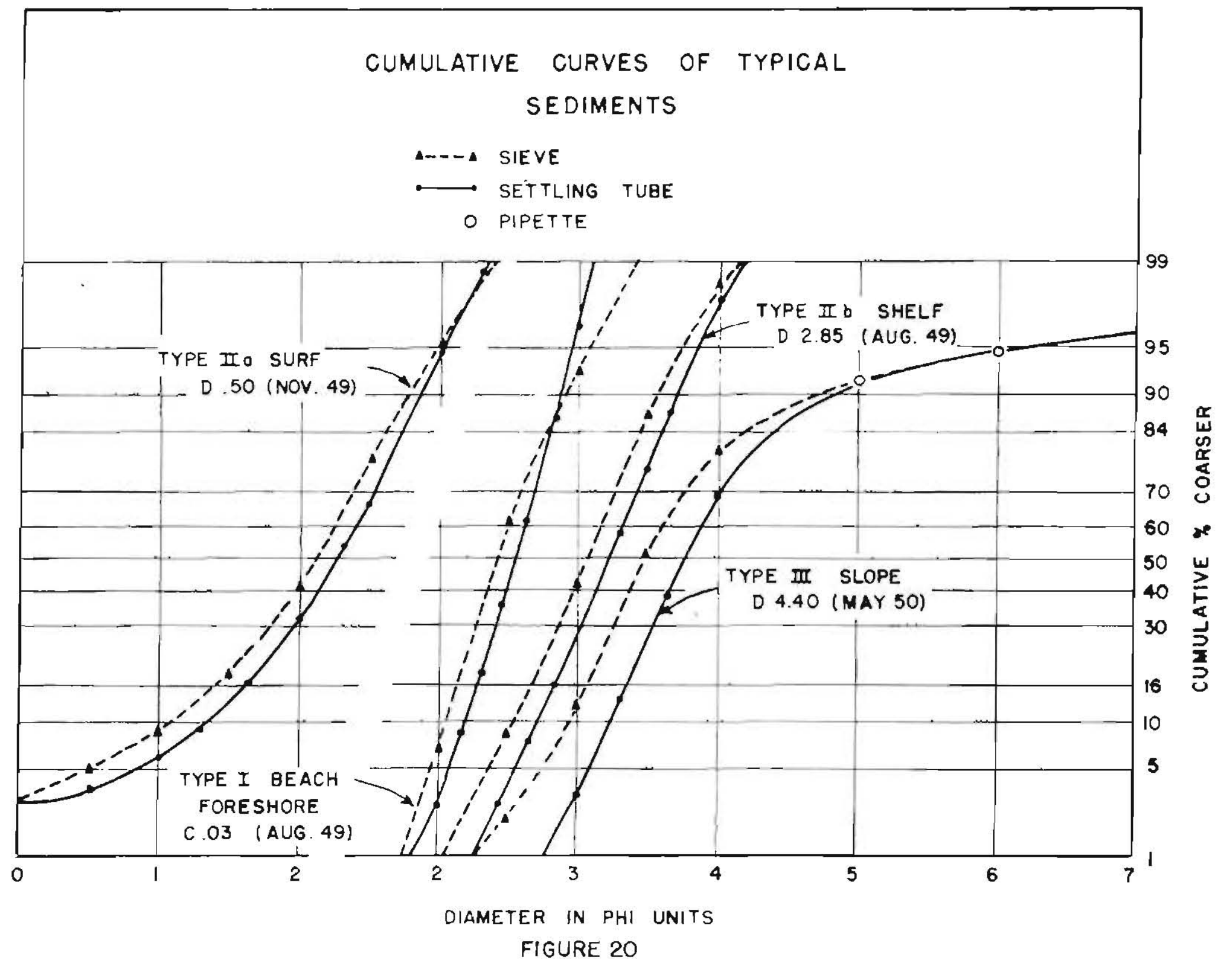


3 percent silt. Seaward of the Type IIb sediments in areas where there is sloping bottorn, the silt content usually increases, the sediment characte wistically has a positive skewness, and is more poorly sorted. These sediments are classed as Type III, and while usually occurring in deeper rater, they are also found in shallow water near the submarine canyon heads. Because they occur only on bottoms where the slope is greater than about 1 on 15, it is thought that slope 1s the most important environmental factor, and they are referred to as "slope" sediments.

The remaining types include sediments from the axis of La Jolla and Scripps Submarine Canyons as Type IVa and IVb respectively, material from the shelf around Point Ia Jolla as Type V, samples from the Recent 20 foot high alluvial cliffs between beach stations $\mathrm{C}$ and $\mathrm{D}$ (figure 2) as Type VI, and a few miscellaneous samples such as those from the flat ridge between the minor branches of Scrifps Canyon (location $S 1.40$, V. 1.4 .3 for example) as Type VII.

Samples from the pocket beaches on Point La Jolla and from the beaches to the north of Scripps are listed as Type I. All of the sediments from the shelf north of Scripps Caxyon fit into environmental Types IIa-b and III. Samples irom the alluvial cliffs, Type VI, are included in appendix II for purposes of comparison, and because of their resemblance to oxidized samples from the wall of La Joila Canyon.

\section{Areal Distribution of Size Measures}

Measures of size distribution were plotted for each survey to show the areal and seasorial variations in the sediments. The three primary measures of size distribution, phi median diameter, phi deviation measure, and phi skewness measure were used for this purpose because they give the essentials of size distribution with a minimum number of variables. The areal distributions of these measures, obtained from the settling tube analysis of the sediments, are shown in parts A through $E$ of figures 21, 22, and 23. For purpcs es of comparison, measures from the sieve analysis for the August survey are al so included as part $B$ (sieve) with each series of figures. The seasonal variations in these measures along $D$ renge are summarized in figures 24 and 24 (sieve), and the values of the size distribution measures along $U$ range north of Scripps Canyon in figure 25.

For the most part, the areal plots of the three measures $11_{\phi} \phi, \sigma \phi$ and $\alpha \phi$, indicated that the measures varied continuously and in a systematic manner from one locality to another, so that contouring could be carried out on $a$ reasonable basis. The median diameters were contoured with an interval of one quarter of a phi unit, and the phi deviation and skewness measures with an interval of one-tenth.

Comparison of sieve and settling tube data: Comparison of size distribution data from settling tube and sieve analysis, parts $B$ and $B$ (sieve) of figures 21,22 , and 23, shows that the patterns of areal distribution are somewhat similar but differ considerably in detail. The 
Figure 21. Areal distribution of phi median diameters for the June, August, November, Karch and Hay surveys. Samples were analyzed by Imery settling tube and pipette methods, except for figure $21 B$ (sieve) which, for purposes of comparison, gives data from sieve and pipette methods. The cobbles noted of $f$ Station $G$ in August are residual. These cobbles are frequently exposed during the summer when the sand covering them has been transported shoreward and deposited on the beach. Note band of relatively coarse sediments (low phi values) in the surf zone, particularly during the winter surveys. Data for parts $A$ through $E$ are listed In appendices IA through IE. 

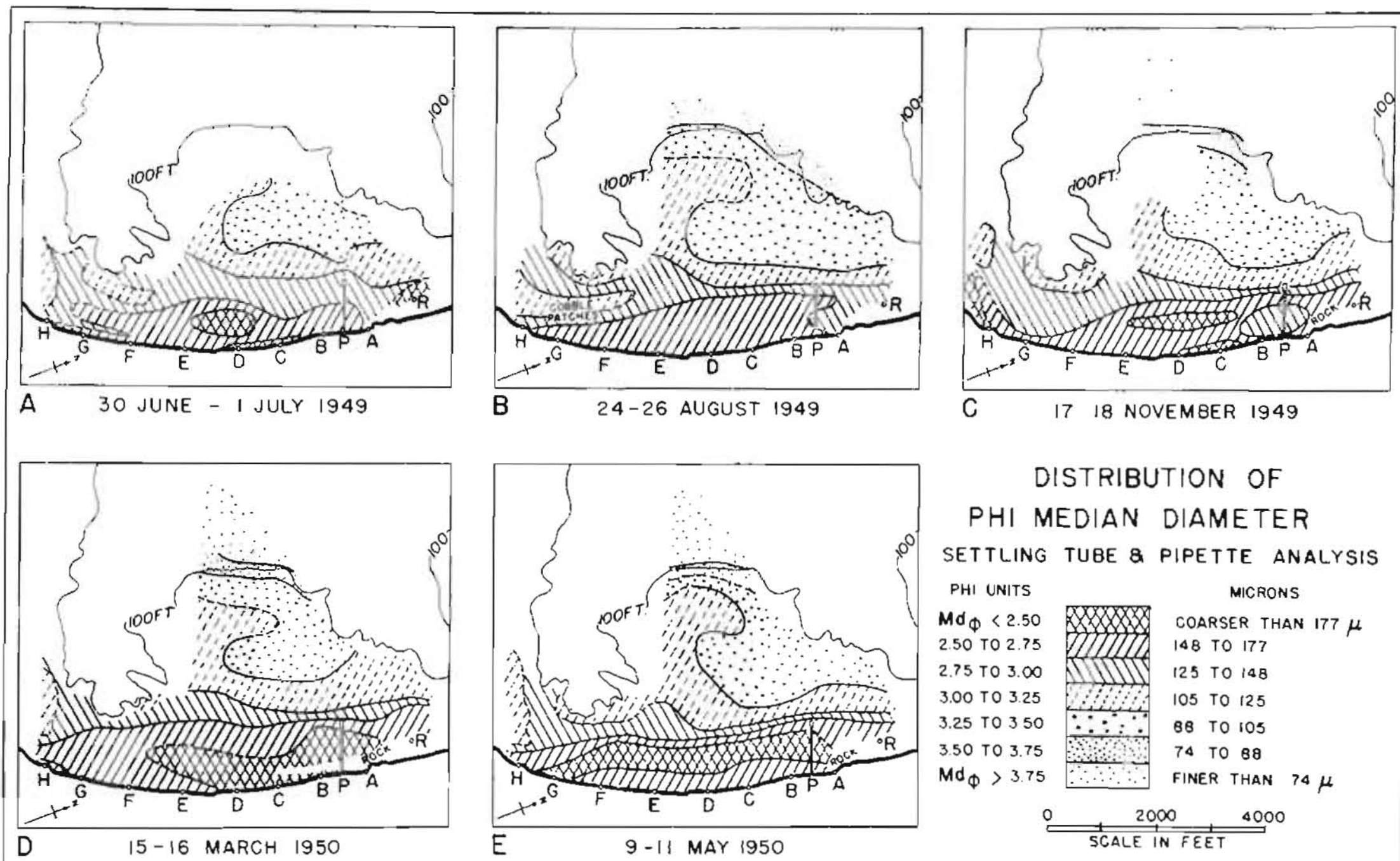

\section{DISTRIBUTION OF}

PHI MEDIAN DIAMETER SETTLING TUBE \& PIPETTE analysis PHI UNITS $M d_{\Phi}<2.50$ COARSER THAN $177 \mu$ 2.50 TO 2.75 PIIJ 148 TO 177 2.75 то 3.00125 то 148 3.00 T0 $3.25 \quad 105$ TO 125 3.25 т0 $350 \quad \because \because \because$ 88 то 105 3.50 TO 3.75 74 TO 88 $\mathrm{Md}_{\Phi}>3.75 \quad \therefore$ FINER THAN $74 \mu$ FIGURE $\frac{2000}{\frac{1}{\text { SCALE IN FEET }} 4000}$ 


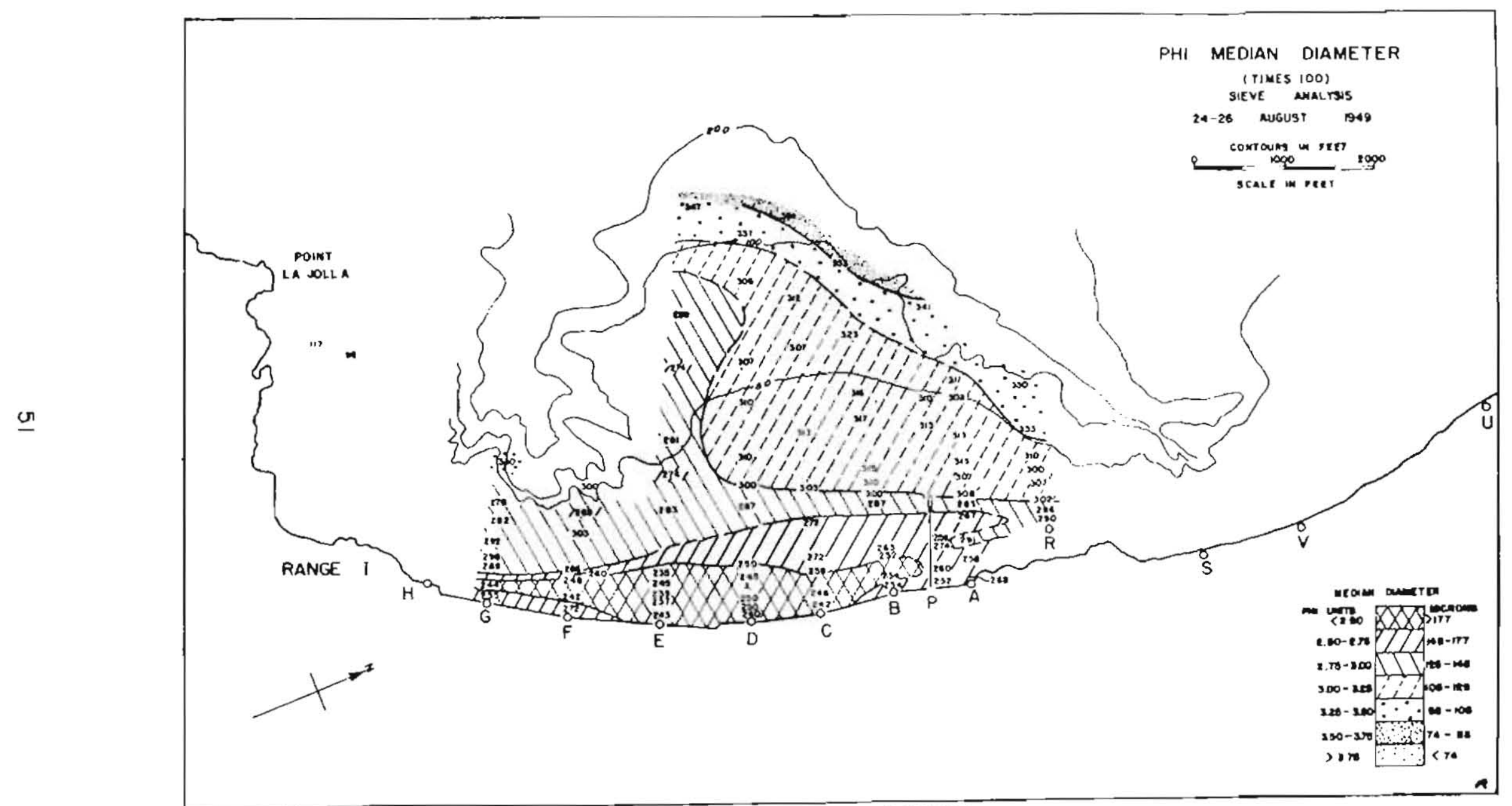

FIGURE 2IB (SIEVE) 
Figure 22 Areal distribution of phi deviation messures for the June, August, November, March and May surveys. Samples were anslyzed by Emery settling tube and plpette methods, except for figure $22 \mathrm{~B}$ (steve) which for purooses of comparison, gives data from sieve and pipette methods. Position of wave convergence zone indlcated by high values of $\sigma_{\not \phi}$ in the surf zone near station D for June, November and Karch and of station $C$ for August. 

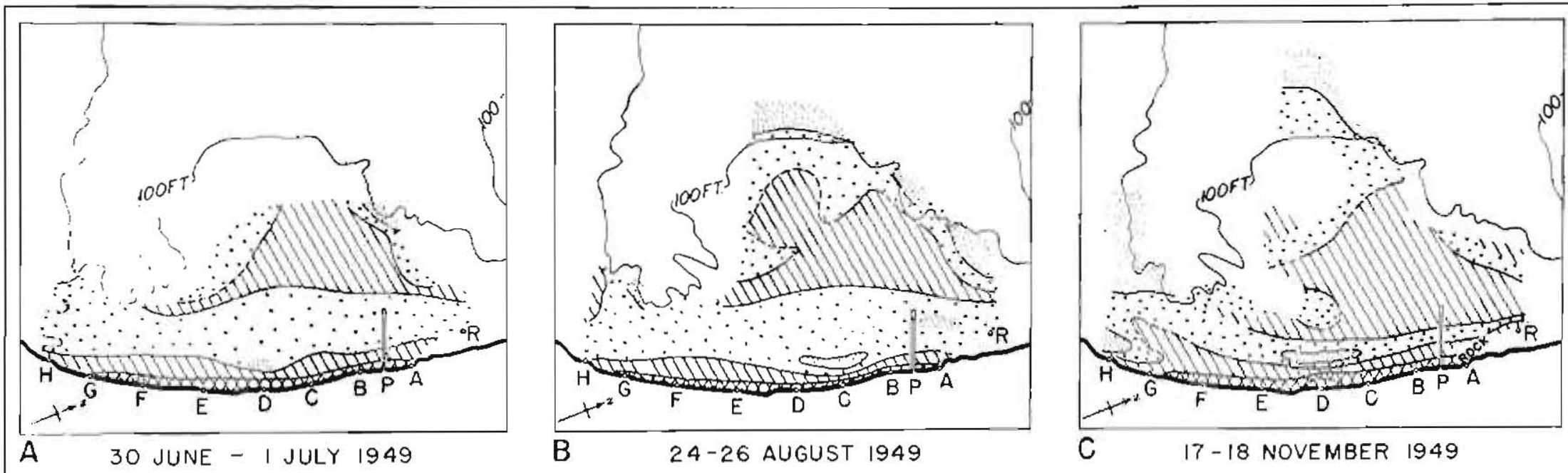

W
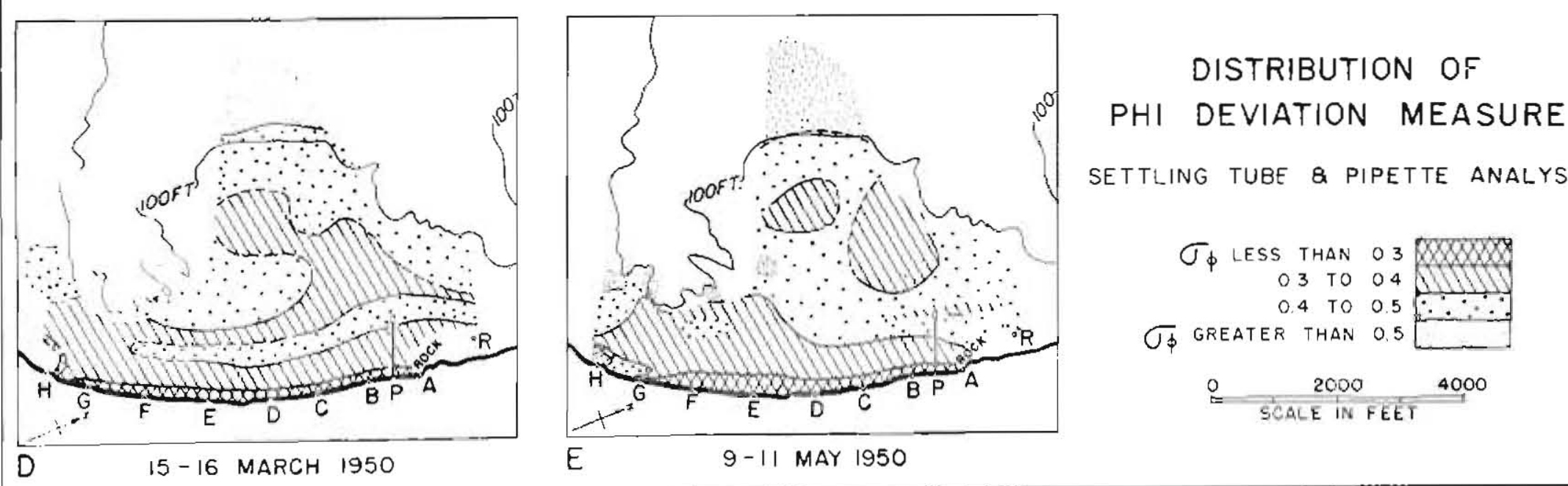

SETTLING TUBE \& PIPETTE ANALYSIS

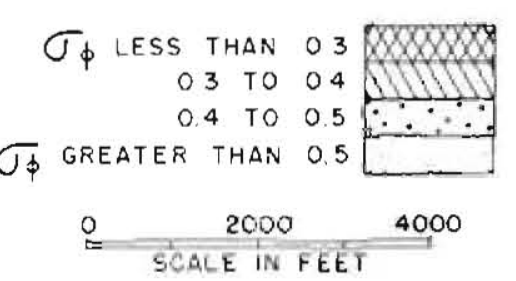

FIGURE 22 


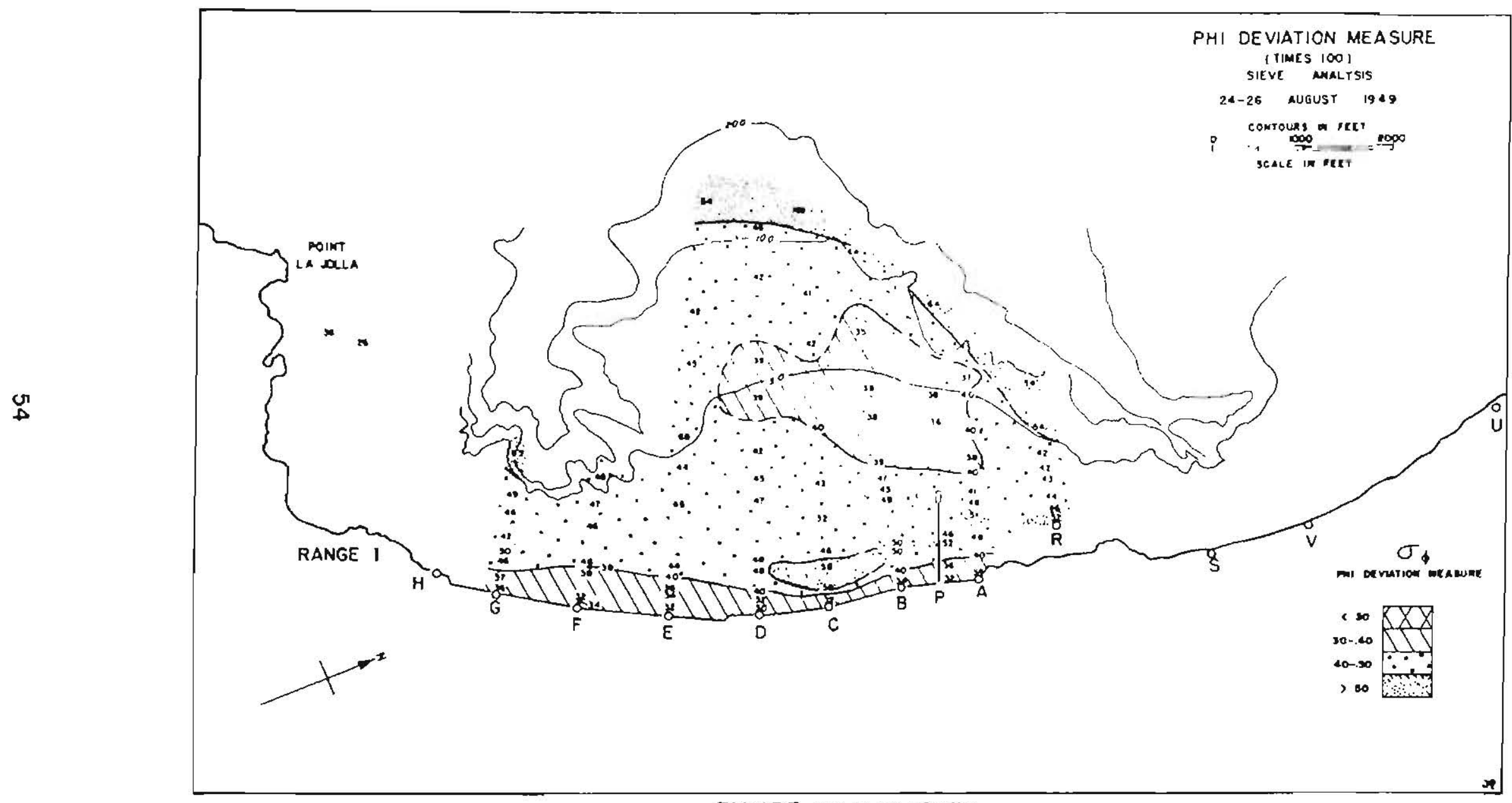

FIGURE $22 \mathrm{~B}$ (SIEVE) 
Figure 23 Areal distribution of phi skewnegs measures for the June, August, November, Karch and May surveys. Samples were analyzed by Energy settling tube and pipette methods, except for flgure $23 \mathrm{~B}$ (sieve) which for purposeg of comparison, gives data from sleve and plpette methods. Vote. the pronounced banding of properties parallel to the beach for all surveys, except in the case of samples analyzed by sieving. 

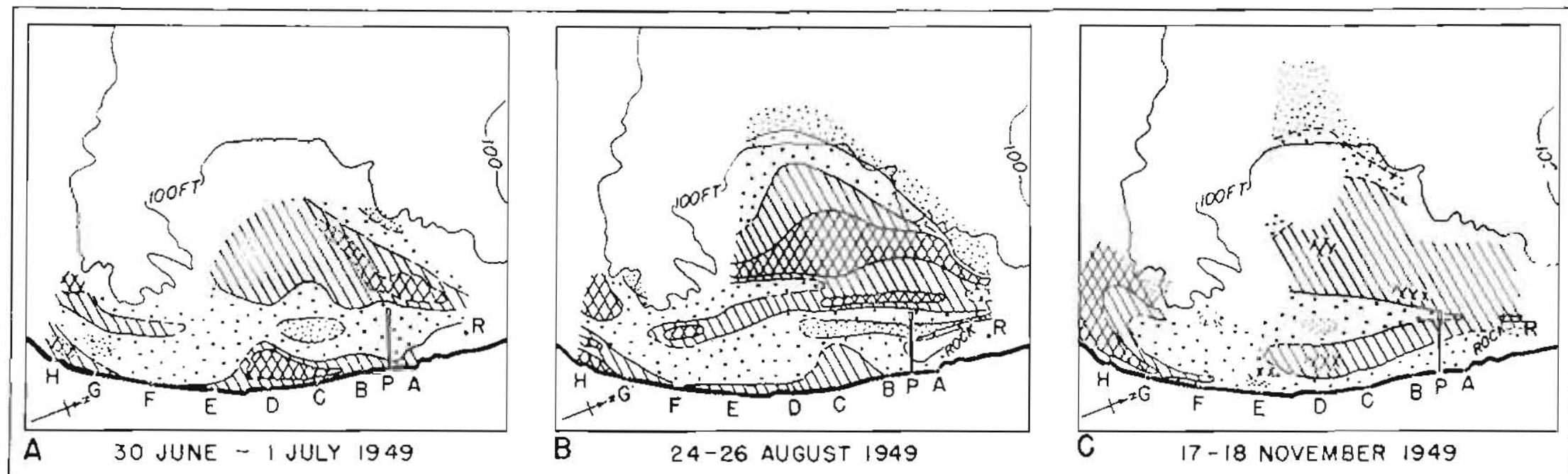

$\pi$

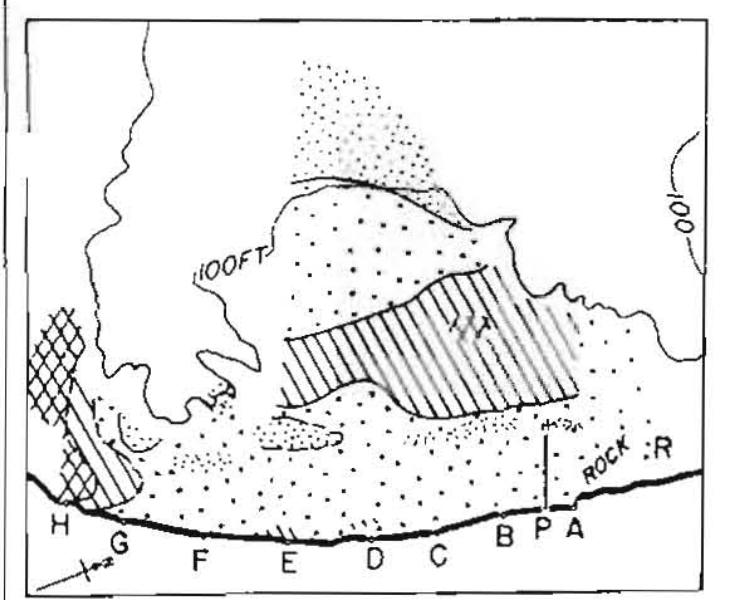

D $15-16$ MARCH 1950

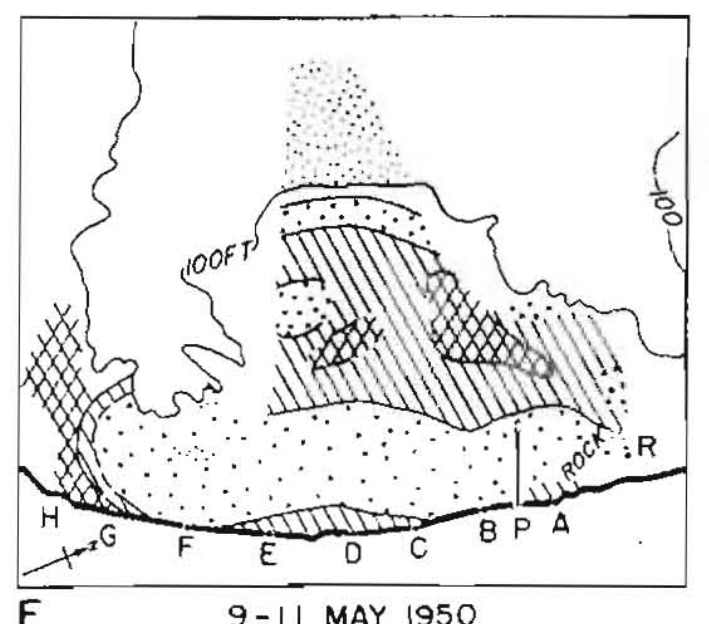

\section{DISTRIBUTION OF} PHI SKEWNESS MEASURE

SETTLING TUBE a PIPETTE ANALYSIS

$\alpha_{\phi \text { Less Than }-0.15 \text { W }}$

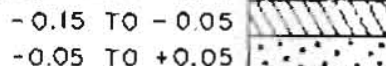

$\alpha_{\phi}$ GREATER THAN+0.05

$\frac{2000}{\text { SCALE IN FEET }} 4000$

FIGURE 23 


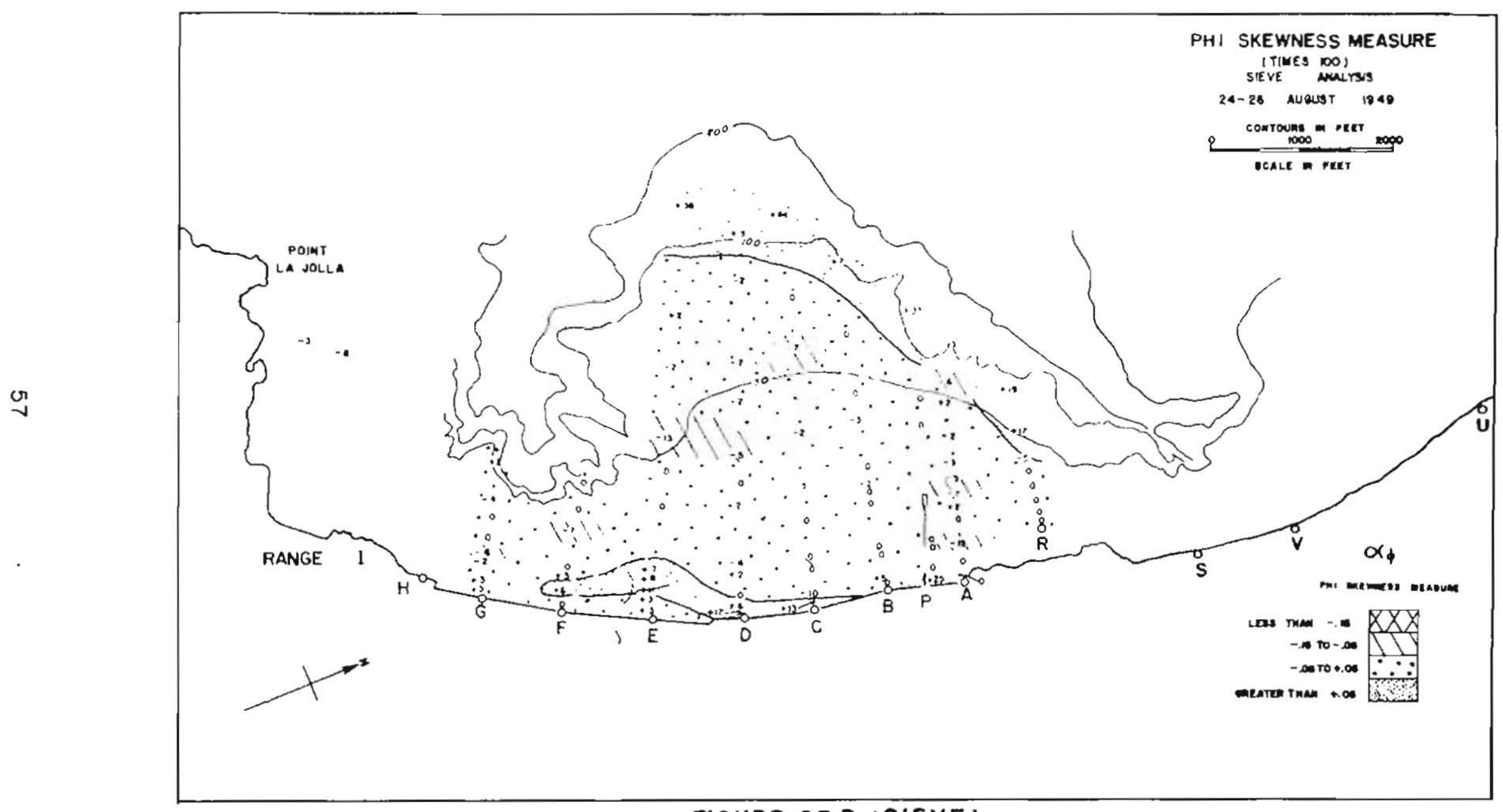

FIGURE 23 B (SIEVE) 
Figure 24 Seasonal variation in size distribution measures of sediments along $D$ range, obtained by settling tube-pipette analysis. The steve-pipette analyses of the samples are shown In figure 24 (sieve) for purposes of comparison. Note the relatively coarse, poorly sorted material in the surf zone, and the change in sediment properties near the increase in slope at depths of 100 reet. A seasonal change from fine median diameterg in the summer to somewhat coarser in the winter is shown between one and two thousand feet from the besch. Compare wh simflar diagram for $U$ range show in rigure 25. 
PHI MEDIAN DIAMETER
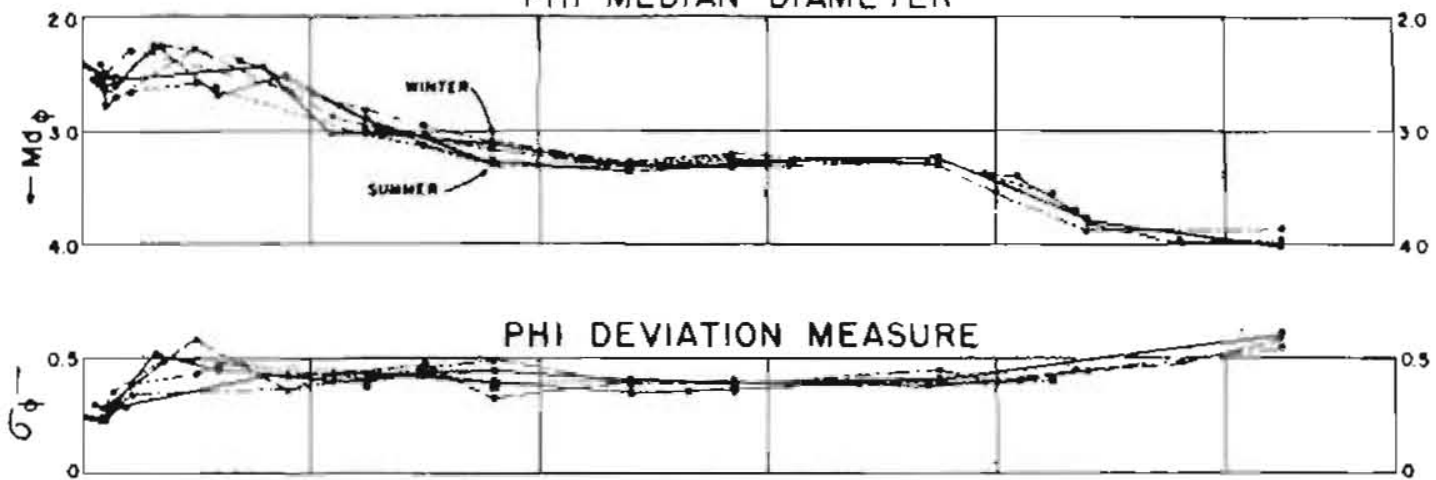

PHI SKEWNESS MEASURES
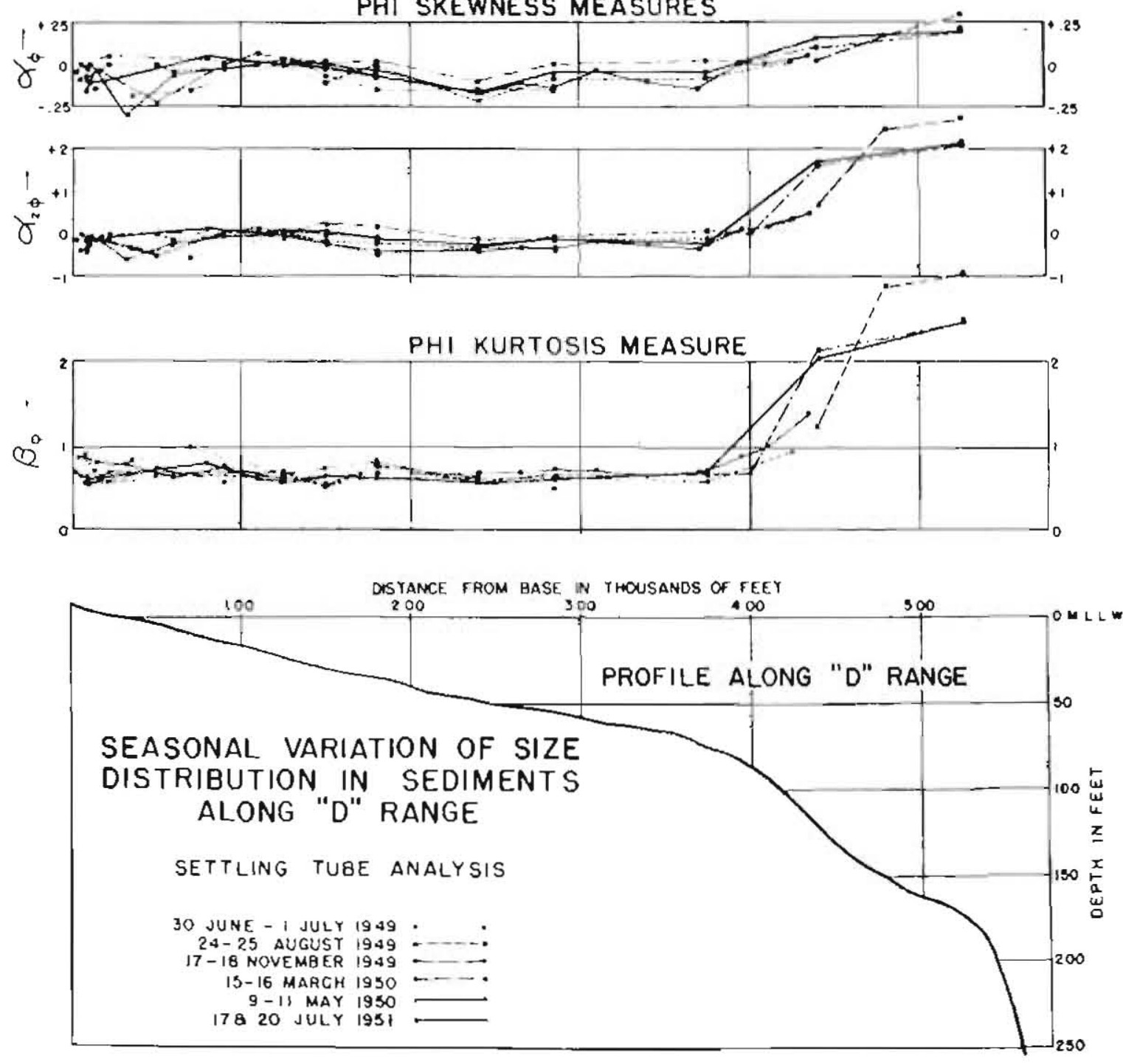

FIGURE 24 

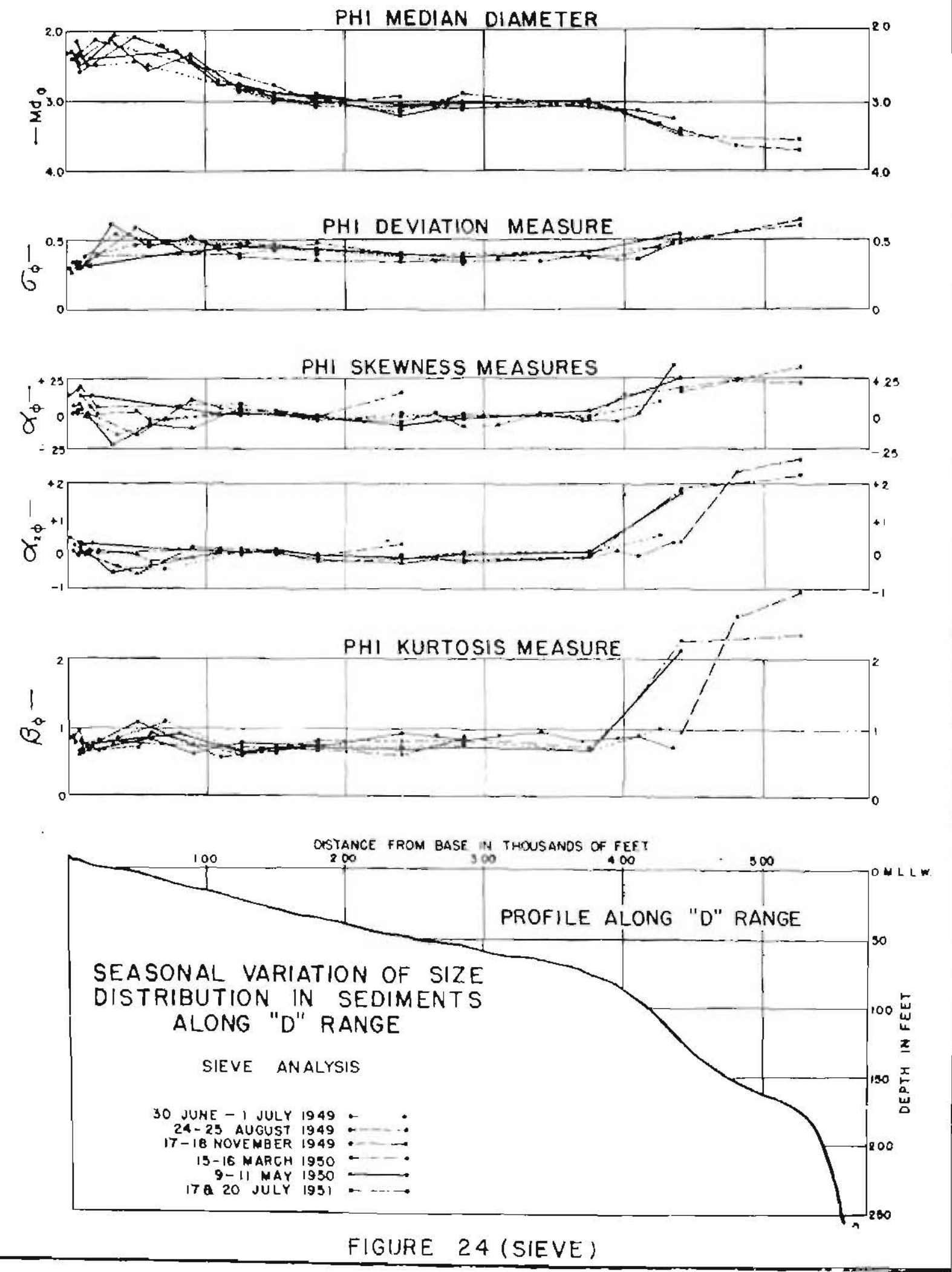
Figure 25 Vartation in size distribution of sediments along U range north of Scripps Canyon. Compare with similar diagram for $D$ range shown in figure 24. Location of stations is shown in figure 1, samples which were not on range, such as $T-8, T-9$, etc., are plotted according to dopth rather than distanc: frcm shore. No samples were obtalned from the surf zone on this range. Note the relative increase in size and decrease in deviation and skewness for sample LC-15 from the axis of La Jolla Canyon. 


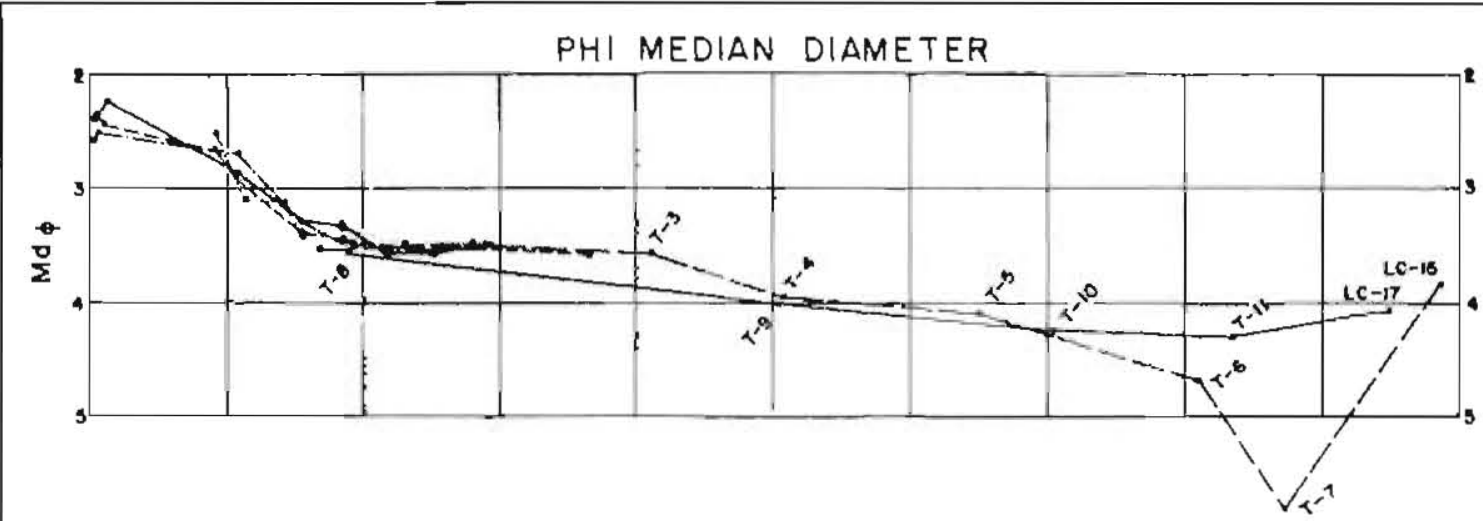

PHI DEVIATION MEASURE
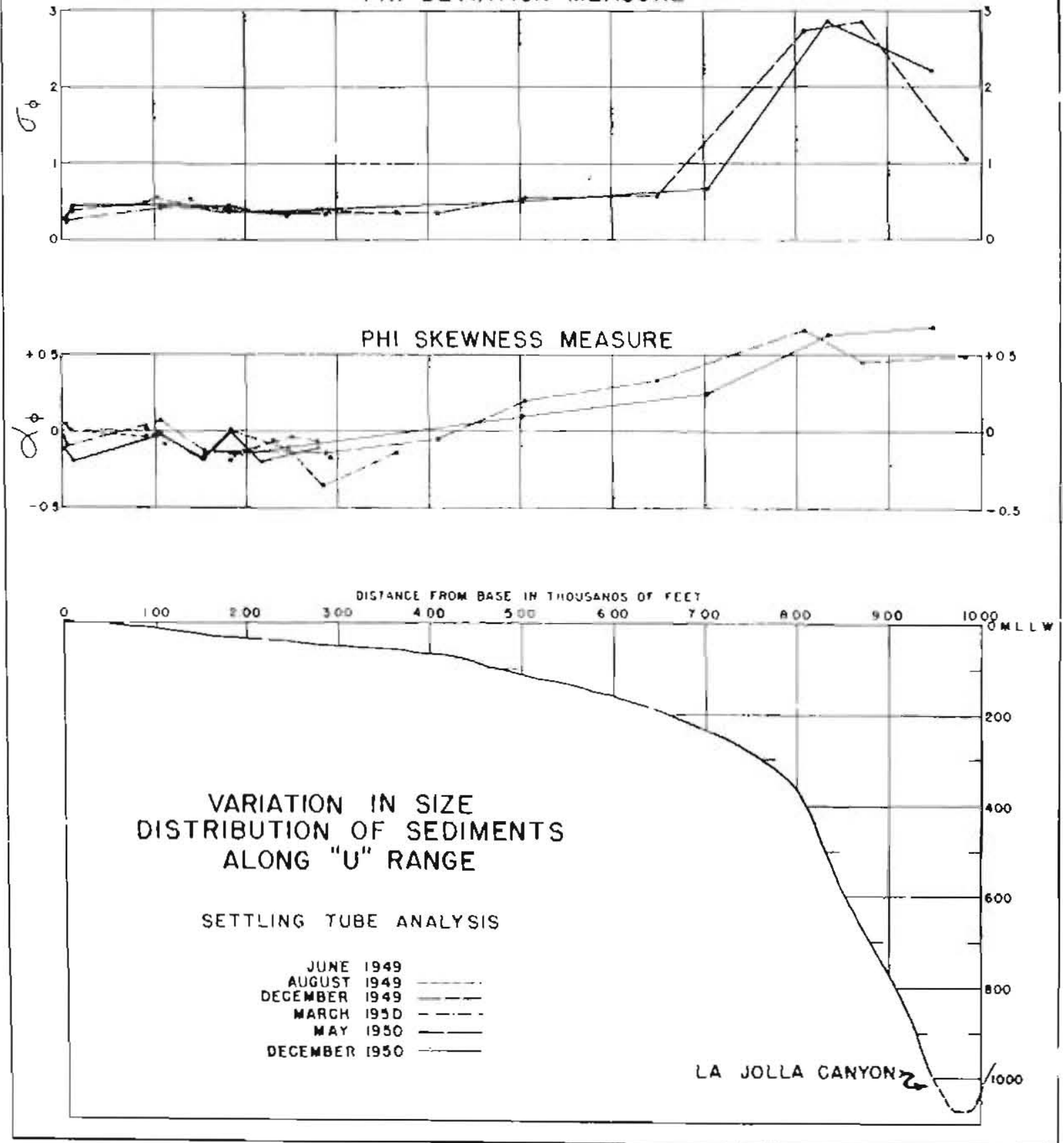

FIGURE 25

62 
principal difference in median diameters, as discussed previously under the section on laboratory analysis, is that values by settling tube average about $0.15 \phi$ higher than by sieving. On the other hand, values of phi deviation measure are generally larger by sieving than by settling tube. This is particularly true on the beach foreshore, where values of

$\sigma \phi$ less than 0.30 are entirely absent for the data obtained by sieving (flgure 22B (sieve)). In general there was a greater tendency toward bimodal distributions in the case of analysis by sieving than for analysis by settling tube (see figure 12, and appendix IB, range A).

The areal distribution pattern of the phi skewness measure, $\alpha \phi$ is noticeably different by the two methods of analysis, except for the "slope" sediments in deeper water where both methods result in large positive values. Although the pattern by settling tube analysis is complex, it shows strong alignment and control, whereas the areal distribution of $\alpha \phi$ values is almost random in $n$ ature for the sieve data. The more systematic areal variation in the measures of size distribution by settling tube methods and the closer correlation between environment of deposition and hydraulic size distribution, as discussed in the following section, are the principal reasons for emphasizing the data obtained by settling tube over that obtained by sieving for this study. However, when investigating the relation between size and beach foreshore slope (figure 7 and appendix III) it was felt that the median dianceter by sieving was perhaps more appropriate than that by Emery settling tube.

Median Diameters: The areal distributions of median diameters for each survey are characterized by a band of coarse material (low phi values) in the surf zone, with somewhat finer material on either side (figure 2l, A-E). Sediments from depths of less than about 10 feet below HLLW were all within the wentworth grade of fine sand $(2.0$ to $3.0 \phi)$. The average median diameters in depths of 15 to 30 feet were $3.0 \phi$, and from 30 to 100 feet the average was about $3.3 \not 6$.

In general, the median diameters of the sediments decrease with increasing dejth beyond the surf zone. An exception to this is the central portion of the intercanyon shelf between depths of 60 and 90 feet, where the sediments are slightly coarser than in surrounding areas. This locality is also anomalous in phi deviation measure and in sediment components such as mica, and heavy minerals. These factors indicate an increase in energy in this locality relative to adjacent areas, and will be considered in greater detall in the conclusions.

The greatest change in sediment size occurs from the beach out to depths of about 30 feet where the seasonal cut and fill was greatest. In this zone the sediments tend to be coarsest during the winter and spring when the beaches are cut back, and finest in the summer and fall. However, the seasonal change in sediment size is readily traced to greater depths. At station $D 1.80$ in depths of 35 feet the median diameter was about $0.20 \%$ finer during the summer surveys of June and August 1949 and July 1951 than for the winter and spring surveys of November 1949 and 
March and May 1950 (figure 24).

There is also an indication of seasonal change at depths of 120 feet on $D$ range near stations 4.00 to 4.25 where the phi median is slightly coarser (lower phi values) for August 1949 and July 1951 than for the winter and spring surveys. Unfortunately the June-July 1949 survey did not extend to this depth. A seasonal tendency is also indicated in this region for values of $\alpha \phi, \alpha_{2 \phi}$ and $\beta \phi$ (figure 24 ). However, seasonal variation in the relatively fine sediments of deeper water is less certain than in the case of the coarser shallow water sediments because the total field and laboratory error in the measures of size discribution for fine sediments are approximately of the same order of magnitude as observed variations in the sediments.

Sorting: The best sorted sediments, as measured by the phi deviation, $\sigma \phi$ were found on the beach fureshore. Another zone of well sorted sediments was commonly found on the intercanyon shelf between depths of about 20 and 60 feet. The sediments were less well sorted, that is, the deviation measure was numerically greater, in the surf zone, and on sloping bottoms near the edge of the shelf. Although the areal distribution of deviation measures varied from one survey to the next, seasonal tendencies were not as pronounced as in the case of medisn diameters.

Skewness: Of the measures of size distribution, the skewness measure showed by far the greatest variation both in areal distribution and with time. (figures 23, A-E). The data from all of the surveys particularly the two during the summer, showed a pronounced banded pattern with alternate zones of positive and negative skewness lying approximately parallel to the beach. While detail of pattern differed from one survey to the next, certain tendencies could be followed throughout the year. Low values of skewness in and near the surf zone graded seaward into a zone of high negative skewness in depths of about 25 to 50 feet, which in turn was followed by positive skewness values on the sloping bottoms and in deeper water.

Sediment Distribution in Adjacent Areas

Sediments from the supplementary stations on the beach and shelf north of Scripps were sinilar to those on the intercanyon shelf except that the northern beach sands were slightly coarser and the shelf sediments (figure 25) somewhat finer than their counterpart from the intercanyon shelf. The difference in shelf sediments can be accounted for by Scripps submarine canyon which prevents the transportation of sediments in deep water from one shelf to the next except as suspended load. Therefore the main source of intercanyon sediment is sand size material transported across the shallow sbelf at the head of the canyon.

As noted previously, the sediments on the rocky shel $f$ around Point La Jolla differ markedly from those of the intercanyon shelf. The Point 
La Jolla sediments occur in patches separated by many low rock outcrops and ridges. These sedjments are coarser, somewhat more rounded, have more shell fragments, are frequently bimodal, and in general do not grade from one type to another as do the shelf sediments to the north. The transition between the Point La Jolla shelf sediments and the fine sands to the north occurs near the head of La Jolla canyon and results in a confused sediment distribution along $H$ range. This is shown in parts $C$ and $E$ of figures 21 through 23, and is the reason that sediments on $H$ and $I$ ranges are classed as La Jolla shelf Type $V$ sedjments rather than as normal shelf Types I through III.

Sediments from the submarine canyons are classified as Type IVa or IVb if they are irom the floor of La Jolla or Scripps Canyons, and as Type III (slope sediments) if they are from the canyon walls. In general the slope sediments from the canyon walls were typical of Type III sediments elsewhere in that they had high phi deviation measures and high positive skewnens. The sediments from the canyon floors present a special problem. They are usually coarser than the adjacent slope sediments, but resemble them in having high positive skewness and high deviation measures (poor sorting). The resemblance to Type III sediments is better in the case of $\mathrm{L}$ a Joll a Canyon sediments than for Scripps Camyon where the $\sigma \phi$ and $\alpha \phi$ values usually plot between Type IIb and III. Changes in measures of size distribution from the shelf to the floor of outer La Jolla Canyon are illustrated in figure 25. Data for stations $\mathrm{SC}-8$ through $\mathrm{SC}-1 \mathrm{l}$, which are in line across the mid section of Scripps Canyon are listed in appendix II.

On three occasions samples of very stiff, well consolidated sediment with oxidized surface and some worm borings were obtained from the steep wall at the head of La Jolla Canyon in depths of 70 to 120 feet. $3 /$ This material was quite different from the unconsolidated fresh appearing modern sediments in the La Jolla region. In size distribution it was most stmilar to the Recent alluvium from stations $\mathrm{AC}-1$ and $\mathrm{AC}-2$ listed in appendix II. It is probable that this material is part of an older formation outcropping on the canyon walls, since it is known that older formations outcrop along the steep walls of both canyons (Shepard, 1949).

Size Distribution Diagrams

Experience has shown that the measures of sediment size distribution are somewhat interdependent, and that a physical relationship exists between the median diameter and the deviation and skewness measures for most water transported sediments (Inman, 1949, and Griffiths, 1951). In general, sediments with median diameters within the wentworth range of fine sand

$$
65
$$

3/ Two of the samples were from stations $G 1.32$ (Nov.) and LC-I and are listed in appendices IC and II. The third sample : as from station $\mathrm{G} 1.48$ on 9 irarch 1950. It is described as being very stiff with oxidized surface and has values of $M d_{\phi}, \sigma_{\phi}$, and $\alpha \phi$ of $7.25 \phi, 5.88 \phi$ and +0.42 respectively. 
tend to be better sorted and more symmetrical than coarser or fine material regardless of the environment of deposition. For this reason it is advantageous in studying the particle-size distribution of a large number of samples to plot them in such a manner that both the variation and the interdependence of the size parameters can be shown. To accomplish this the descriptive measures of the bottom sediments were plotted on a size distribution diagram in which the phi deviation and skewness measures are plotted against the median diameter. Diagrams of this type for each survey of Scripps Beach and the intercanyon shelf sediments are shown in figures $26 \mathrm{~A}-\mathrm{E}$, and a compilation of all surveys in figure $26 \mathrm{~F}$.

It is sometimes convenient to visualize the median, deviation, and skewness in the size distribution diagram as the $x, y$, and $z$ axes of $a$ Cartesian coordinate system in space. In this sense the pattern of plotted points delineate solids in space, and the number of plots per unit volume indicate the density of the solid. Since different symbols are used to represent different environments of deposition, the density of plot of a given symbol is a measure of the degree of similarity of the size distribution of sediments from that particular environment.

Inspection of the size distribution diagrams shows that there is a high degree of sinilarity in the size distribution of sediments within a given environment, and in a three dimensional s ense, that there is practically no overlapping from one type to another. As mentioned previously, the basic consideration in typing or classifying the sediments was the environment or location of deposition. However, the decision as to what constitutes an environment, in so far as size distribution is concerned, was made on the basis of areal distribution of size measures (figures 21-23) and its validity ascertained by the pattern and desnity of plot on the size distribution diagrams.

For example, the areal distribution diagrams indicated that beach foreshore samples could be considered as a separate type from the offshore samples. The position and density of plotted points on the size distribution diegram tend to confirm this. On the other hand, while samples from the surf zone and shelf tend to differ from one another, the size distribution diagram indicates that they form a gradational series, with no sharp line of demarkation between them. For this reason samples from the surf and near shore zone between the beach foreshore and approxinately 1000 feet from shore are arbitrarily classified as sub-Type IIa, while samples from the relatively horizontal shelf beyond are listed as sub Type IIb. Sediments seaward of the shelf type, where the bottom slopes are about 1 on 15 or greater, are quite different from the shelf sediments and are classified as Type III. The areal distribution of sediment types is shown in figure 27.

It is interesting to note that while surf zone and beach stations are quite close together, their samples have decidedly different characteristics. on the other hand, samples across the reletively broad ares of surf and 
Figures 26A-F. Size distribution diagrams for the June, August, November, Yarch and iiay surveys. The sieve-pipette analyses of the August data are shown in figure $26 \mathrm{~B}$ (sieve) for purposes of comparison. The areal distributions of $i d \phi, \sigma_{\phi}$, and $\alpha_{\phi}$ for each survey are show in figures 21,22 , and 23 , and the distribution of sediment types in figure 27. Dashed lines connect type IIb and III sediments which occur on the sane ranse, and are from progressively deeper stations. A compilation of data from ali surveys is shown in figure 26F. 

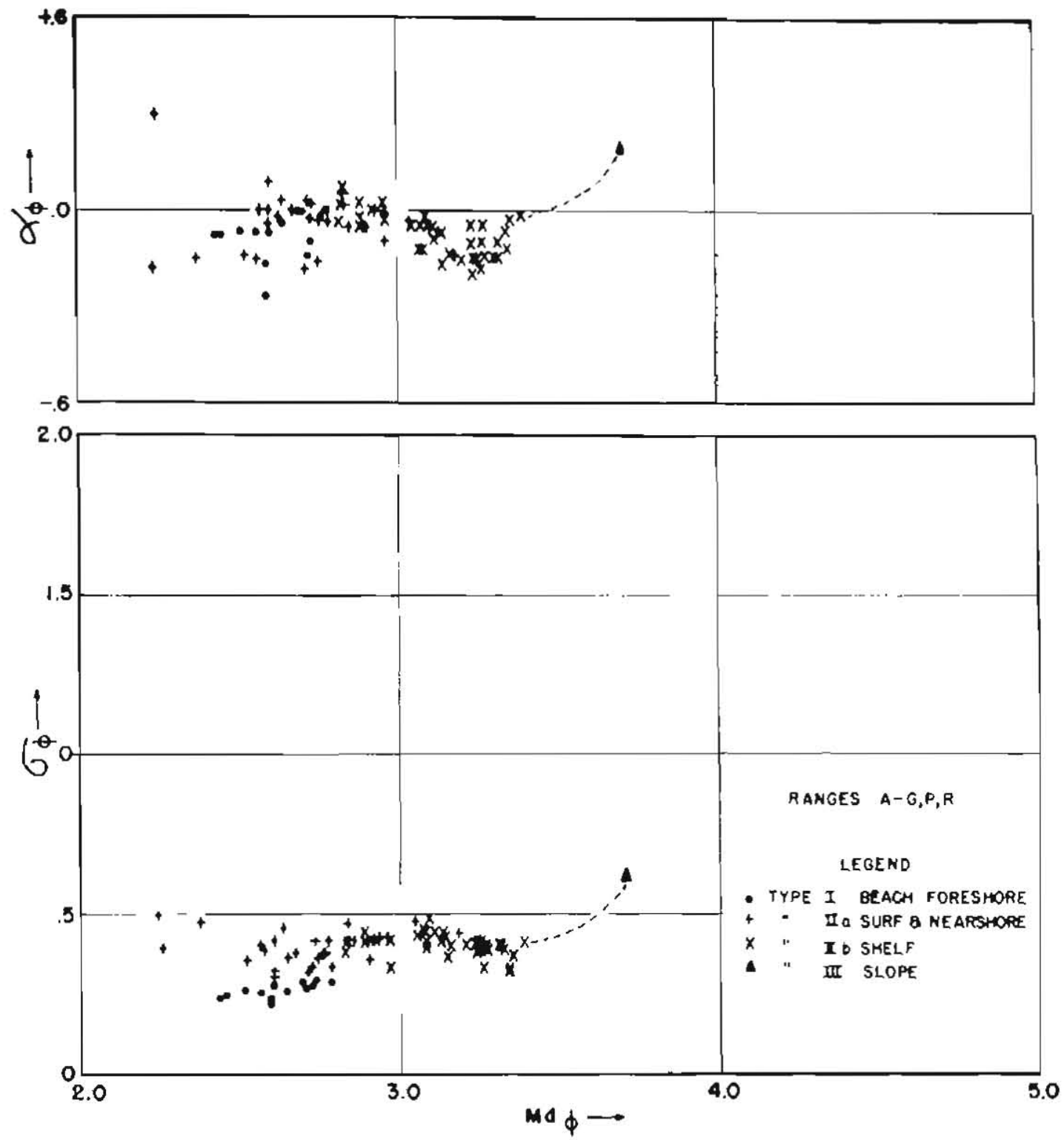

SIZE DISTRIBUTION DIAGRAM

SETTLING TUBE ANALYSIS

30 JUNE - I JULY 1949

FIGURE $26 \mathrm{~A}$ 

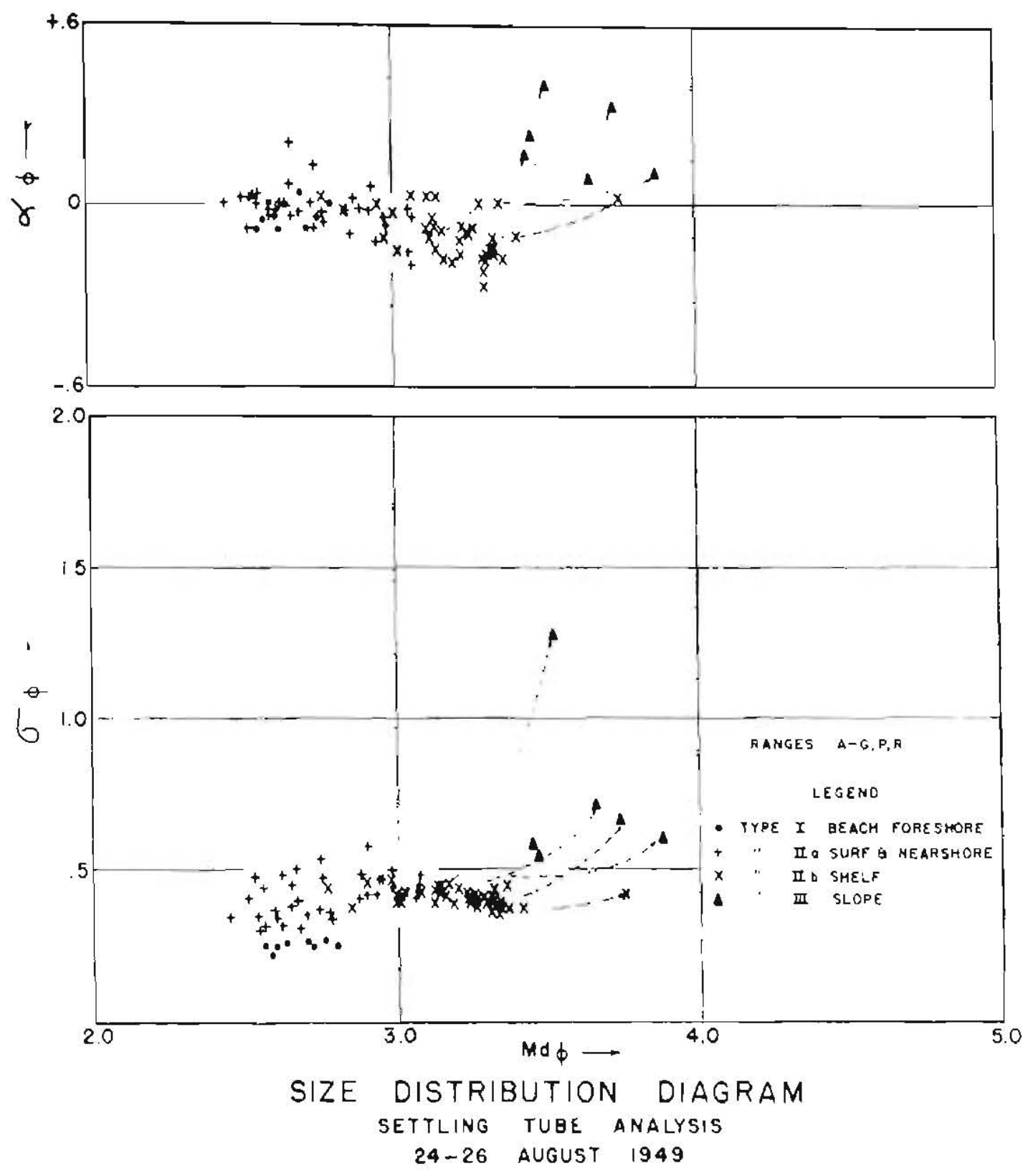

FIGURE $26 \mathrm{~B}$ 

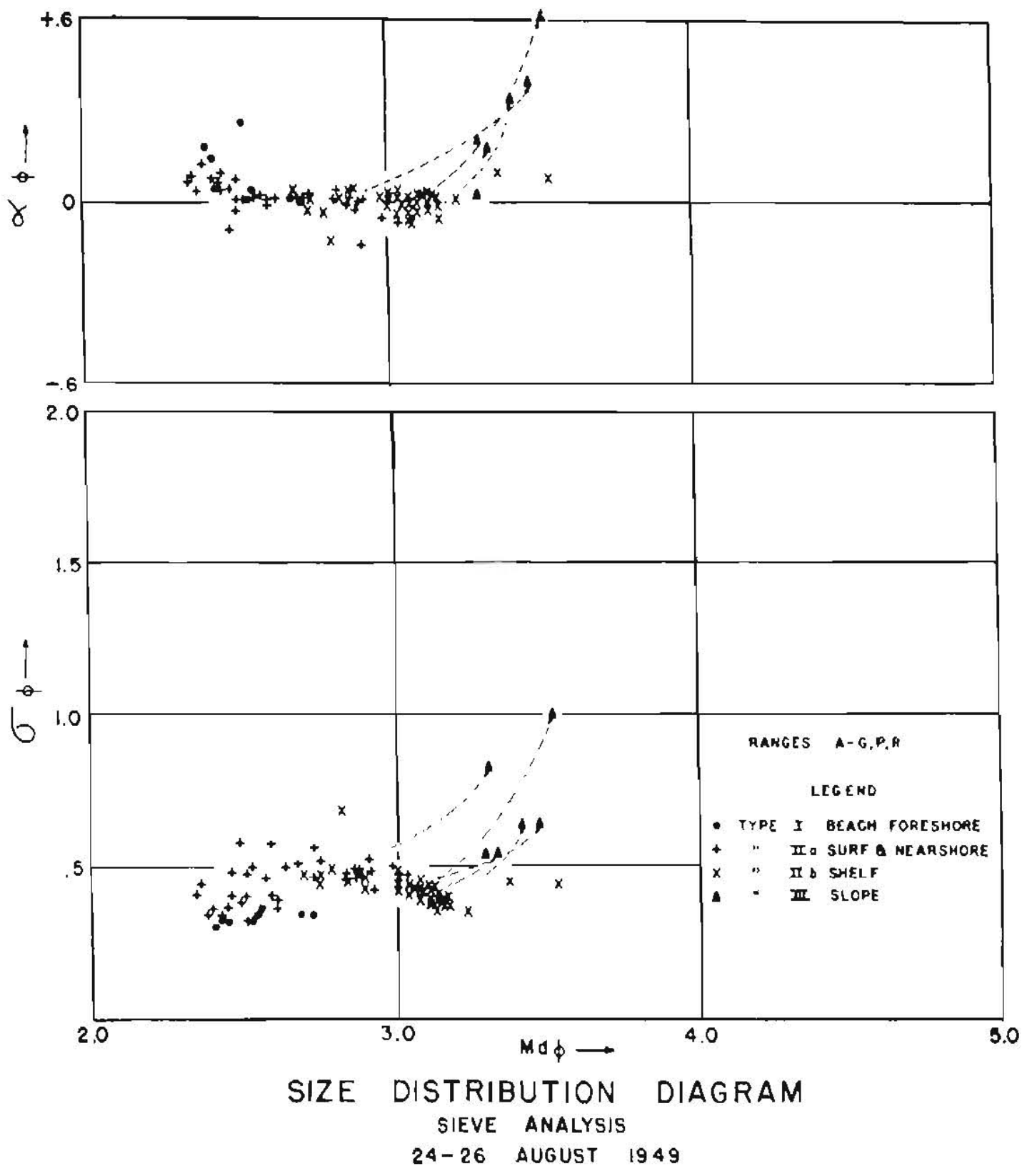

FIGURE 26 B (SIEVE) 

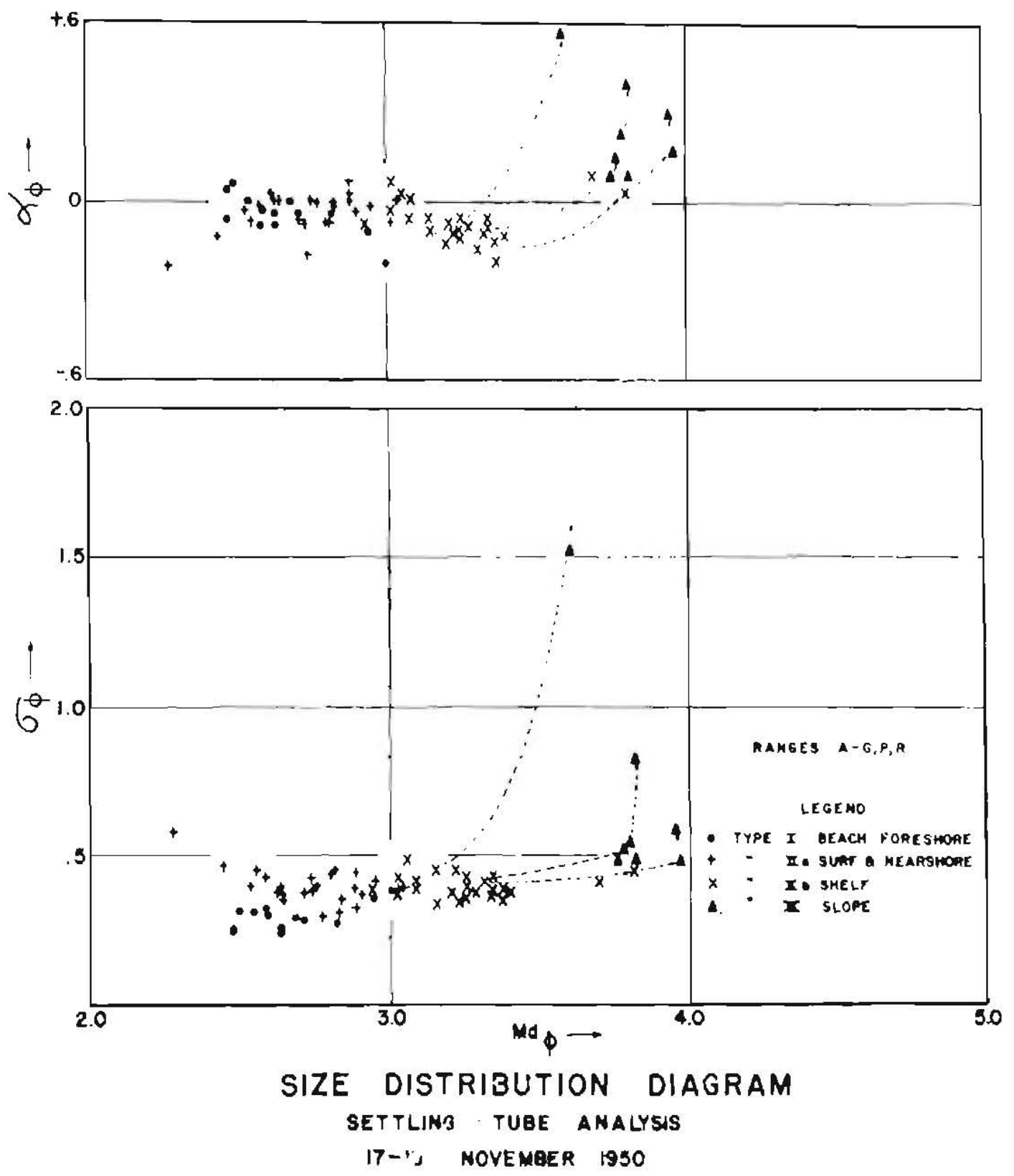

FIGURE $26 \mathrm{C}$ 

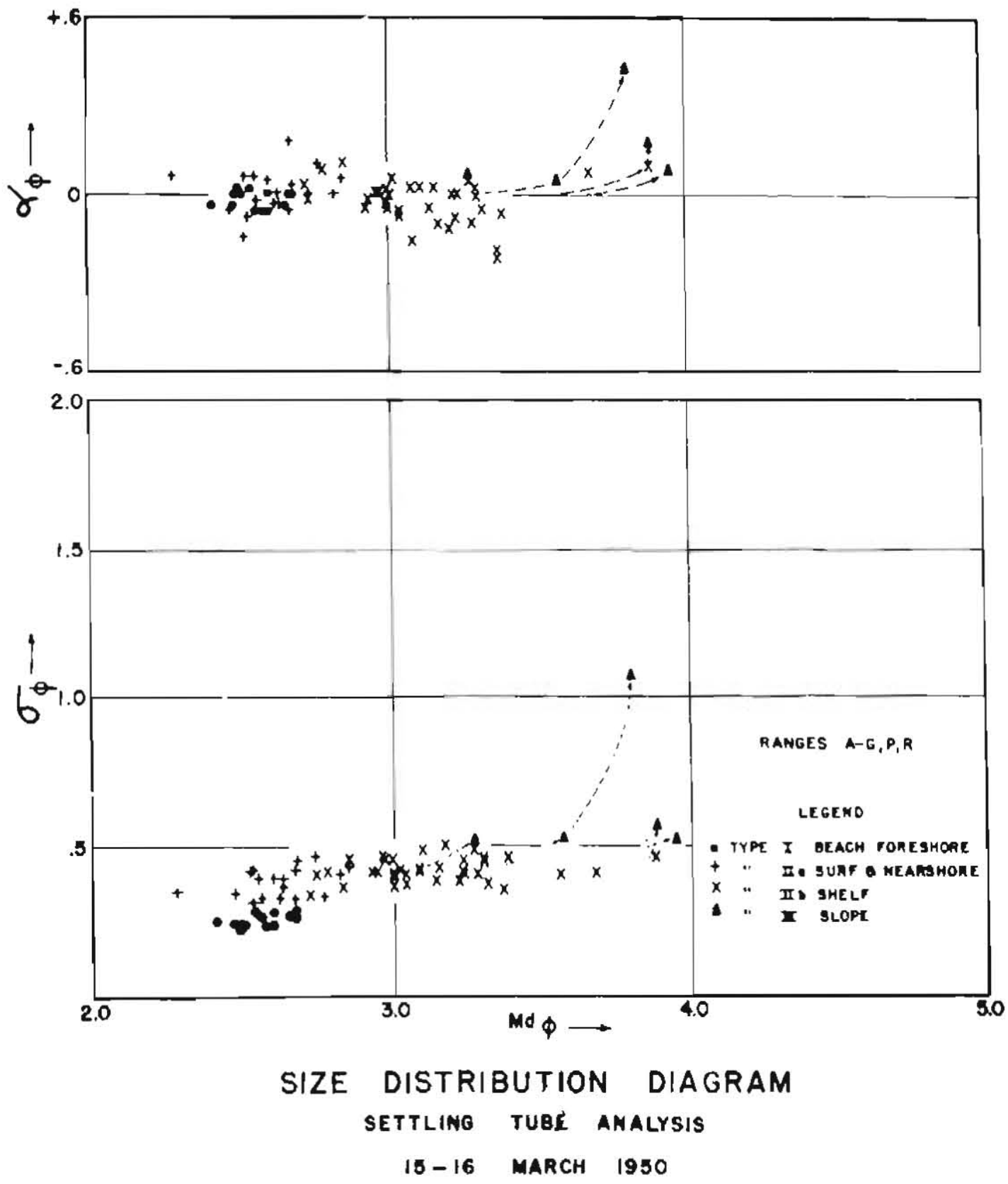

FIGURE 260 

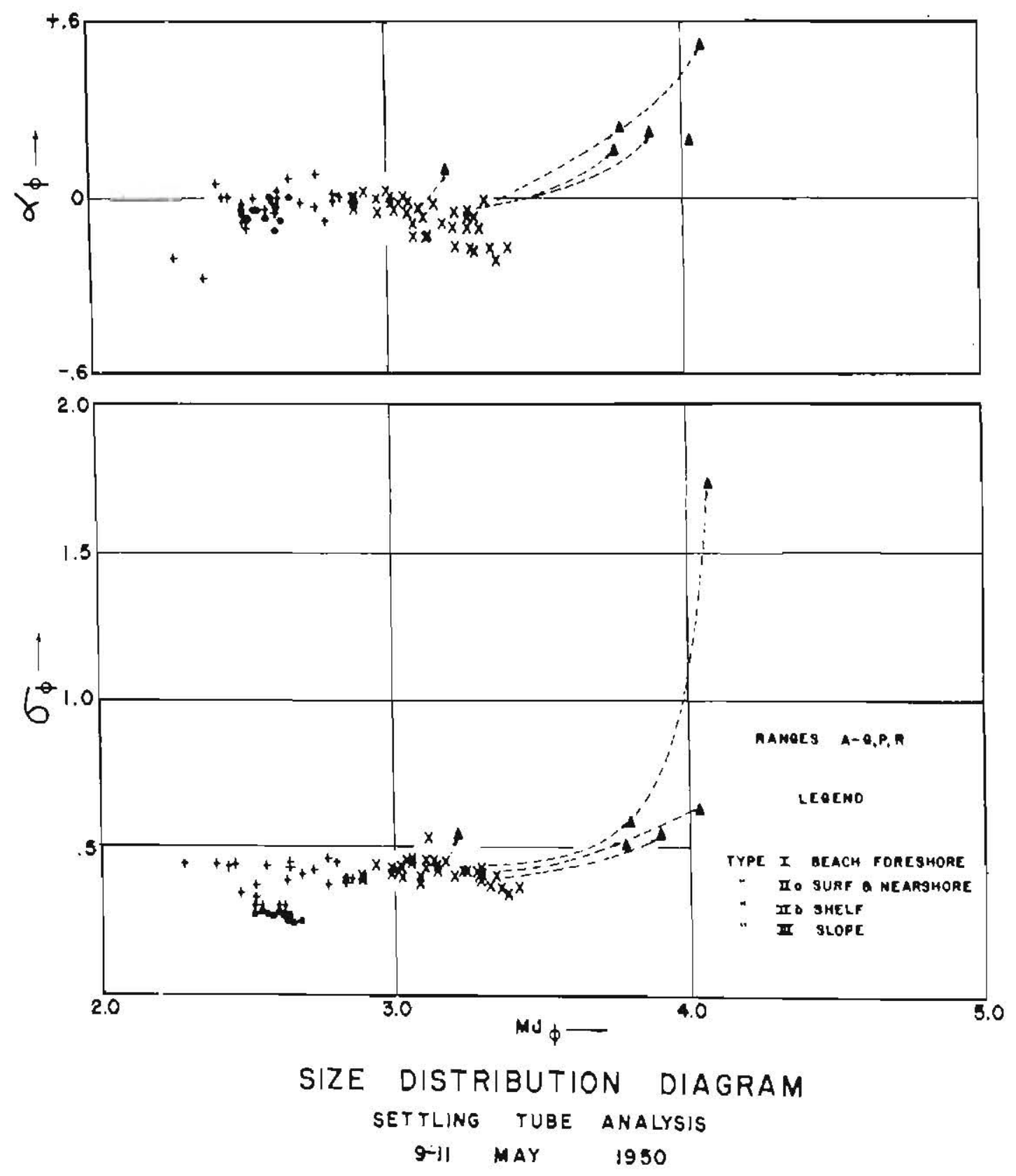

FIGURE $26 E$ 

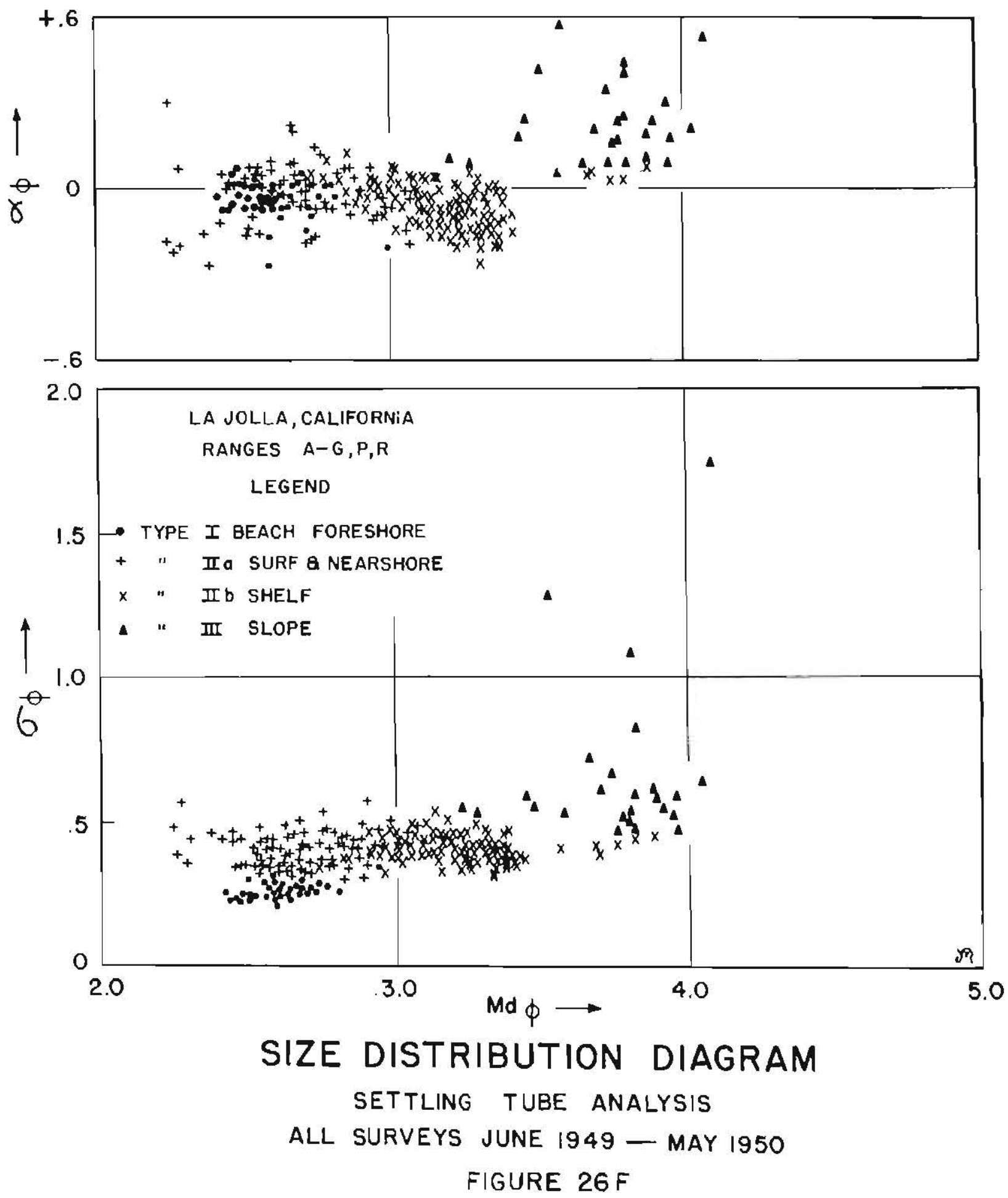


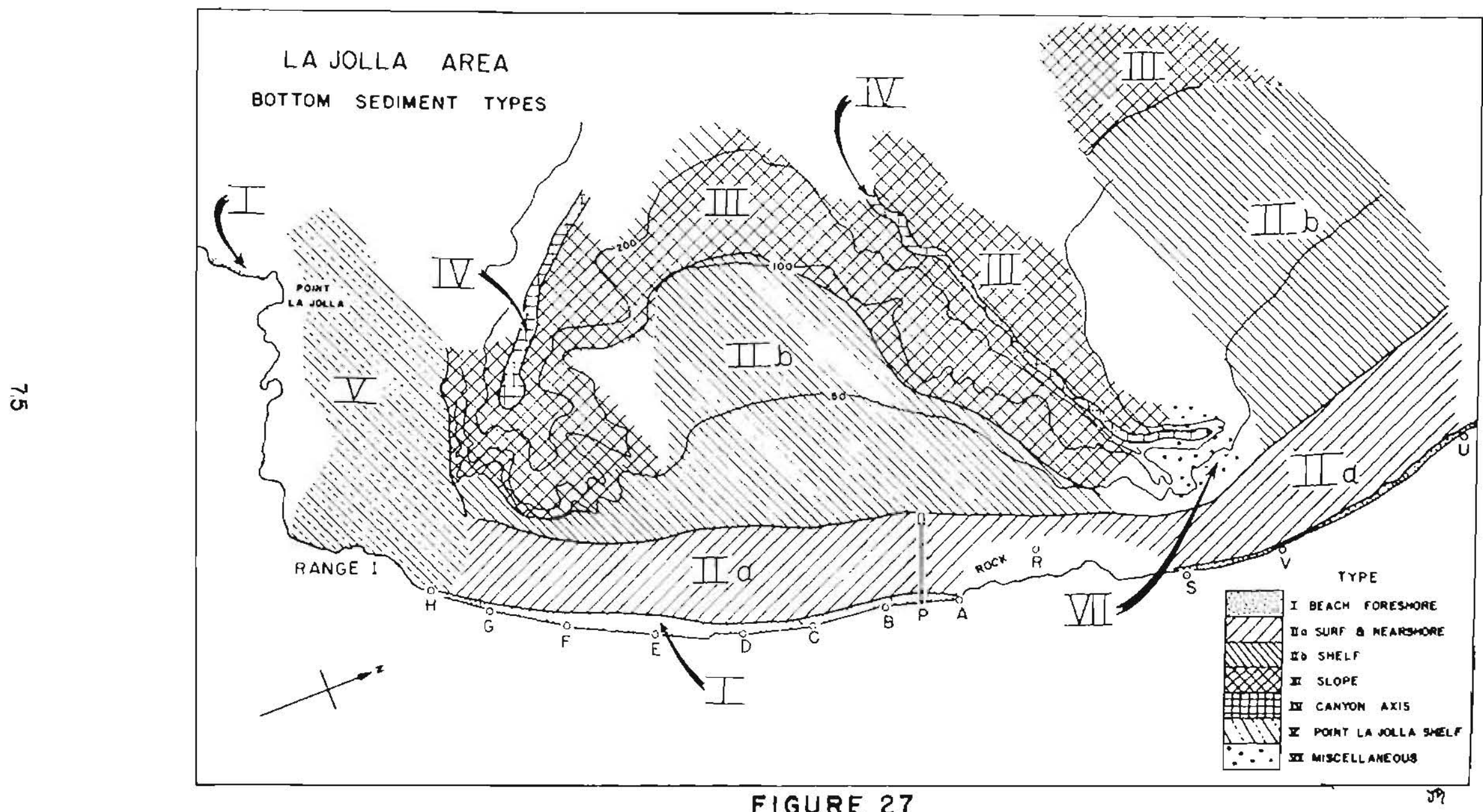


shelf grade systematically from point to point. Again, as in the case of beach to surf, the transition from shelf to slope sediments takes place in a relatively short distance, and although the slope sediments do not plot in as dense a group as the others, they are easily distinguished by their poor sorting and high positive skewness. In areas where the submarine canyon heads are close to the beach, sediments from beach to slope usually go through the same general cycles as along other traverses where the slope is some distance from the beach. The chief difference is that, where submarine canyon heads are close to the beach, the shelf or surf zone sediments are coarser near the break in slope and consequently the slope sediments are also somewhat coarser.

\section{SUMUARY AND CONCLUSIONS}

This study has shown that the areal distribution of certain physical properties of beach and nearshore sediments tend to be continuous, and that these attributes vary in a systematic manner with in the environment. Seasonal factors such as wave energy and direction of approach result in marked seasonal variations of some sediment properties, but in general seasonal changes in the sedjments are not of sufficient magnitude to over shadow properties that can be attributed to the location or environment of deposition of the sediment. That is to say, while seasonal factors are manifest in the variation of sediment properties with time, and are very important in determining rates of transportation and deposition, they are not as important as environmental factors in determining the attributes of the sediment. This is illustrated by comparisons of the areal distributions of such attributes as heavy mineral content, amount of micaceous material, and measures of size distribution (figures 14, 16, 21, 22, and 23) with the summary of the seasonal variations of these properties along $D$ range (figures $1 B$ and 24 ) and with the environmental characteristics shown in the size distribution diagrams (figures $26 \mathrm{~A}-\mathrm{F}$ ). Such a comparison shows that in general seasonal variations are of lesser magnitude than the average change in properties from one environment to another, such as from beach to surf zone or from shelf to slope.

The importance of envirommental factors in determining sediment properties enabled the samples from Scripps Beach and the intercanyon shelf to be grouped into three general types depending upon their location. Sediments within these envirommental types - beach, surf and shelf, and slope, all have particle-size distributions that can be correlated with environment. On the other hand, samples from the rocky shelf around Point La Jolla, where sediment coverage is not continuous but occurs in isolated patches, were frequently bimodal and showed no such correlation with environment. This illustrates the importance of local conditions in producing special effects, and indicates that caution must be used in extrapolating findings from one area to another. Apparently the limiting factor on the Point La Jolla shelf is the lack of continuity of sediment distribution. This results in numerous isolated sediment bodies, each with its own charactoristics of size distribution. Mixing of unlike sediments probably accounts for the bimodal distributions found in the La Jolla 
shelf sediments. However, the similarity in the properties of sediments from the intercanyon shelf with those from comparable localities on the shelf north of Scripps Canyon and from more distant areas such as the beach and shelf near Point Mugu, California (Inman, 1950b) suggest that the relations, found in the vicinity of Scripps Beach, between sediment attributes and environments of deposition have some application to beach and nearshore areas in general.

The areal distribution patterns show that there is a pronounced aligninent of sediment properties, which in general is parallel to the beach and surf zone. This feature of sediment distribution is important to the understanding of nearshore processes, because it suggests that processes causing such alignment and banding of sediment attributes should in the main have isolines of intensity parallel to the beach. This suggests, for example, that on the scale of the sampling grid of these surveys, the primary features of the sediment size distribution are not the result of transport en masse through the surf zone and over the shelf along narrow axenues, such as by rip currents. Extensive application of such a process should result in mixing of sediment types and an alignment of s ediment properties perpendicular to the beach, a condition which was not pronounced near the surf zone. An exception to this line of reasoning may occur in the case of high wave with short periods. The positions of rip currents resulting from iave action of this type are not stable, and there is a tendency for the currents to migrate in a random manner from place to place along the beach, and thus possibly result in a uniform distribution of sediment. However, the location of rip currents and the nature of the nearsiore water circulation are important factors in determining certain sediment attributes such as the distribution of micaceous material (see figures 4 and 16).

There are numerous possible interpretations of the alignnent and banding of sediment attributes. It is reasible for example that standing waves or reinforcement of waves such as surf beat may result in alternate bands of intensification and rarefraction of energy which is reflected in the properties of the sediment. Another explanation may lie in the seaward transportation of sediment by diffusion, resulting from a horizontal gradient in concentration of suspended material from the surf zone where concentrations are high, to offshore areas where they are relatively low. If such a process were operative, it could explain the zones of alternate skewness (figure 23), because the nature and amount of transported material, and the effective distance of transport would be a function of the duration and intensity of wave action. Each increase in wave intensity, and particularly each storm period, should result in seaward transportation and deposition of material that differed somewhat from the material already in situ. In addition to seaward transportation by diffusion, it is possible that a net onshore transportation of sediments may occur along the bottom because of the differential between the onshore and offshore velocities associated with the orbital motion of nearshore waves (Grant, 1943). Such transport would probably be selective in that it would move certain types of material more easily than others, and the location and 
intensity of erosion or deposition would be a function of wave character and depth of water. It is conceivable that the summation of effects of processes such as these could result in the banded tendency observed in sediment properties, particularly in zones of al ternate skewness.

The effectiveness of Scripps Submarine Canyon in limiting the longshore transport of material to the narrow zone of shallow water at the head of the canyon is indicated by the relatively coarse sediments on the intercanyon sinelf, as compared with sediments from comparable depths on the shelf north of the canyon (figures 24 and 25), even though the beach sands are finer along Scripps Beach than on the beaches to the north. The comparative absence of fine material on the intercanyon shelf implies that longshore transport of fine material may, in the absence of barriers such as Scripps Canyon, occur well seaward of the breaker zone.

However, there are factors other than the source of sediments triat influence the distribution of sediments on the intercanyon shelf, as indicated by the oval zone of relatively coarse material which occurs on the outer portions of the shelf in depths of 60 to 90 feet of water. This zone is unusually rich in heavy minerals and low in micaceous material (figures 14 and 16); both of these are attributes which indicate an intensification of bottom agitation. As in the case of longshore alignment of sediment properties, the properties in themselves cannot define the effective agent of deposition, but can place definite limits on the nature of the process. At present there appear to be at least two prom cesses worthy of consideration in this regard; an increase in the intensity of tidal scour near the break in slope as suggested by Fleming and Revelle (2939), or a convergence of long period waves such as surf beat as described by Willians and Isaacs (1952) and discussed in the section under waves and currents. The importance of either of these processes in causing an increase in bottom agitation or scour could be ascertained by current or long period wave measurements in the area.

The extreme variability in the relative concentrations of certain minerals both with time and location raises some question as to the interpretation of mineral abundance studies in nearshore sediments. Certainly no simple relationship exists between the amount of any particular mineral and its position on the beach. There appears to be good evidence for selective sorting of material on a basis of size, shape, and density, and the relative importance of these factors apparently changes markedly with time and location (see figures 13 through 18). In this regard it is probable that ancmelies in physical properties may at tiries result in the transportation of certain material in a direction contrary to that of the net transport.

Comparisons of size distributions of the sediments by sieving and by hydraulic methods show that the latter technique give somewhat more meaningful results in a study of the areal distribution of sediment attributes. The increased homogeneity of sediments when considered in terms 
of hydraulic size suggests that investigations utilizing hydraulic methods should be more widely adapted and that improved settling velocity techniques should be perfected. Also, it may be more diagnostic in studies of mineral abundances to segregate on a basis of hydraulic size rather than the more common method of separation by sieving. 


\section{BIBLIOGRAPHY}

Bascom, W. N. 1951. "The relationship between sand size and beachface slope", Trans. Amer. Geoph. Union, Vol. 32, No. 6, pp.866-874.

Carter, G. F. 1950. "Evidence for Pleistocene man in southern California", Geographical Review, Vol. XI, pp. 84-102.

Emery, K. 0. 1938. "Rapid method of mechanical analysis of $s$ ands," Jour. Sed. Petrol., Vol. 8, No. 3, pp. 105-11l.

Emery, K. O. and K. E. Stevenson. 1950. "Laminated beach sand," Jour. Sed. Petrol., Vol. 20, No. 4, pp. 220-223.

Fleming, R. H., and R. Revelle, 1939. "Physical processes in the ocean" in Trask ted.), Recent Marine Sediments, pp. 48-14I.

Grant, U. S. 1943. "Waves as a send-transporting agent" . Amer. Jour. Science, Vol. 24l, pp. 117-123.

Griffiths, J. C., 1951. "Size versus sorting in some Caribbean sediments," Jour. of Geology, Vol. 59, pp. 211-243.

Hazen, Allen. 1914. "Storage to be provided in impounding reservoirs for municipal water supply," Trans. Amer. Soc. Civil Engin., vol. 77, pp. 1539-1669,

Hoel, P. G. 194.7. Introduction to mathematical statistics, John Wiley \& Sons. $258 \mathrm{pp}$.

Hough, J. L. 1940. "Sediments of Buzzards Bay, Massachusetts," Jour. Sed. Petrol., Vol. 10, pp. 19-32.

Hough, J. L. 1942. "Sediments of Cape Cod Bay, Massachusetts," Jour. Sed. Petrol., Vol. 12, pp. 10-30.

Inman, D. L. 1949. "Sorting of sediments in the light of fluid mechanic s," Jour. Sed. Petrol., Vol. 19, No. 2, pp. 51-70.

Inman, D. L. 1950a. "Beach Study in the vicinity of Mugu Lagoon, Calif.," Beach Erosion Board, Tech. Memo. No. 14, $47 \mathrm{pp}$.

Inman, D. L. 1950b. "Submarine topography and sedimentation in the vicinity of Mugu Submarine Canyon, Calif.," Beach Erosion Board, Tech. Memo. No. 19, $45 \mathrm{pp}$.

Inman, D. L. 1952. "Measures for describing the size distribution of sediments," Jour. Sed. Petrol., Vol. 22, No. 3, pp. 125-145.

Inman, D. L. and W. H. Quinn. 1952. "Currents in the surf zone," Proc. Second Conf. Coastal Engin., Houston, Texas, 1951, Council on Wave Research, pp. 2L-36. 
Isaacs, J. D., E. A. Williams, and $\mathrm{C}_{a r l}$ Eckart. 1951 "Total reflection of surface waves by deep water," Trans. Amer. Geoph. Union, Vol. 32, No. I, pp. 37-40.

Krumbein, W. C. 3.934. "The probable error of sampling sediments for mechanical analysis," Amer. Jour. Science, Vol. 27, No. 159, pp. 204-2IL.

Krumbein, W. C. 1936. "Application of logarithmic moments to size frequency distributions of sediments," Jour. Sed. Petrol., Vol. 6, No. I, pp. 35-47.

Krumbein, W. C. 1938. "Local areal variation of beach sands," BuIl. Geol. Soc. Amer., Vol. 49, pp. 653-658.

Krumbein, W. C. 194l. "Measurement and geological significance of shape and roundness of sedimentary particles," Jour. Sed. Fetrol., Vol. II, No. 2, pp. 64-72.

Krumbein, W. C., and E. Aberdeen. 1937. "The sediments of Barataria Bay", Jour. Sed. Petrol., Vol. 7, No. I, pp. 3-17.

Krumbein, W. C. and J. S. Griffith. 1938. "Beach environment in Little Sister Bay, Wisconsin", Bull. Geol. Soc. Amer., Vol. 49, pp. 629-652.

Krumbein, W. C., and F. J. Pettijohn. 1938. Manual of sedimentary petrography. D. Appleton-Century. $549 \mathrm{pp}$.

La Fond, E. C. and R. S. Dietz. 1948. "New snapper-type sea floor sediment sampler." Jour. Sed. Petrol., Vol. 18, pp. 34-37.

Ludwick, J. C. 1950. "Deep water sand layers off San Diego, California," Dissertation, Scripgs Institution of Oceanography, Univ. of California.

Munk, W. H. 1949. "Surf Beats", Trans. Amer. Geoph. Union., Vol. 30, PP. $849-854$.

Munk, W. H. and ir. A. Traylor. 1947. NRefraction of ocean waves: a process linking underwater topography to beach erosion," Jour. of Geology, Vol. 40, No. 1, pp. I-26.

Otto, G. H. 1937. "The use of statistical methods in effecting improvements on a Jonés Sample Splitter", Jour. Sed. Petrol., Vol. 7, pp. 110-132.

Poole, D. M., W. S. Butcher, and R. L. Fisher. 1951. "The use and accuracy of the Emery Steeling Tube for sand analysis," Beach Erosion Board, Tech. Memo. No. 23, 12 . pp. 
Rittenhouse, G. 1943. "Transportation and deposition of heavy minerals," Bull. Geol. Soc. Amer., Vol. 54, No. 12, pp. 1725-1780.

Scripps Institution of Oceanography, Univ, of California, 1947. "A statistical study of wave conditions at five open sea localities along the California coast," Wave report No. 68 (mimeographed).

Shepard, F. P. 1949. "Terrestrial topography of submarine canyons revealed by diving," "Bull. Geol. Soc. Amer., Vol. 60, pp. 1597-1612.

Shepard, F. P. 1951. "Mass movements in submarine canyon heads", Trans. Amer. Geooh. Union, Vol. 32, No. 3, pp. 405-418.

Shepard, F. P., and D. L. Inman, 1950. "Nearshore water circulation related to bottom topography and wave refraction," Trans. Amer. Geoph. Union, Vol. 31, No. 2, pp. 196-212.

Shepard, F. P. and D. L. Inman, 1951a. "Nearshore circulation," Proc. First Conf. Coastal Engin., Chap. 5, pp. 50-59.

Shepard, F. P. and D. L. Inman. 1951b. "Sand movement on the shallow inter-canyon shelf at La Jolla, Calif.," Beach Erosion Board, Tech. Memo. No. 26, $29 \mathrm{pp}$.

Hadell, Hakon. 1932. "Volume, shape, and roundness of rock particles", Jour. of Geology, V $2.40, \mathrm{pp} .443-451$.

Wadell, Hakon, 1935. "Volume, snzpe, and roundness of quartz particles," Jour. of Geology, Vol. 43, pp. 25C-280.

Williams, E. A., and J. D. Isaacs, 1952. "The refraction of groups and of the waves which they generate in shallow water," Trans. Amer. Geoph. Union., Vol. 33, lio. 4, pp. 523-530. 


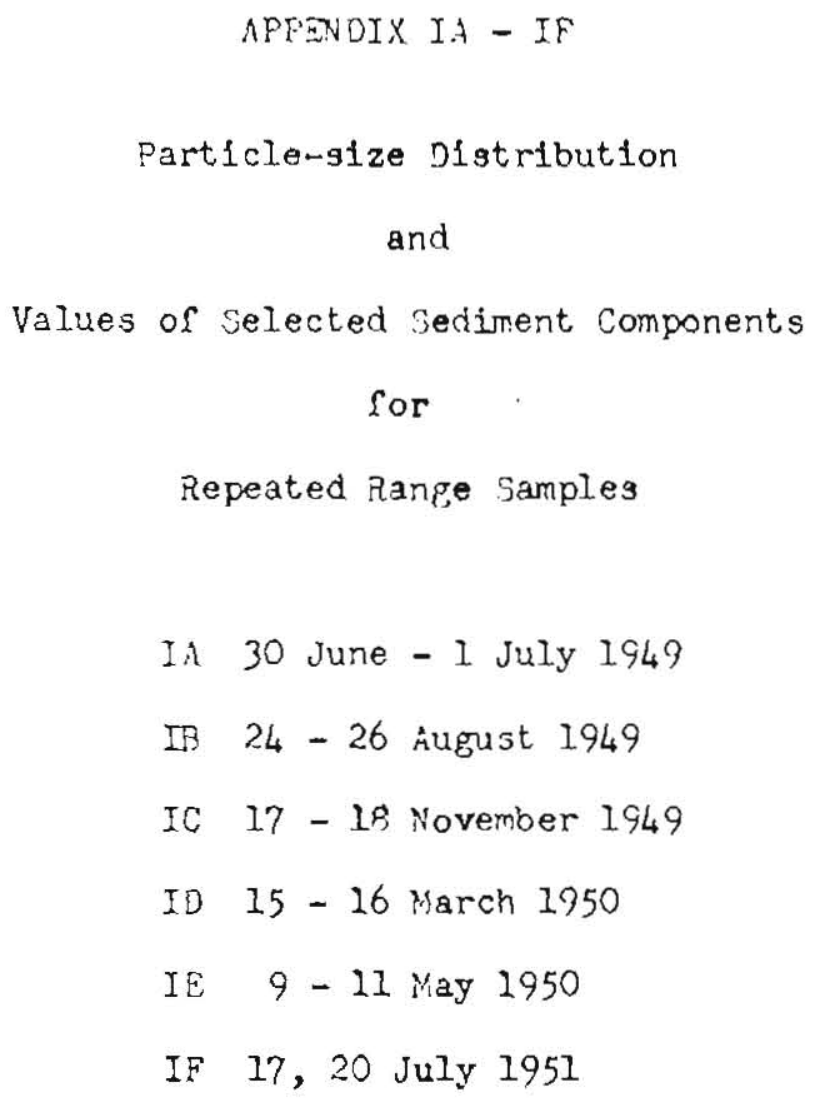


APPINDIX IA

30 June - 1 July 1949, Beach and Bottom jediments

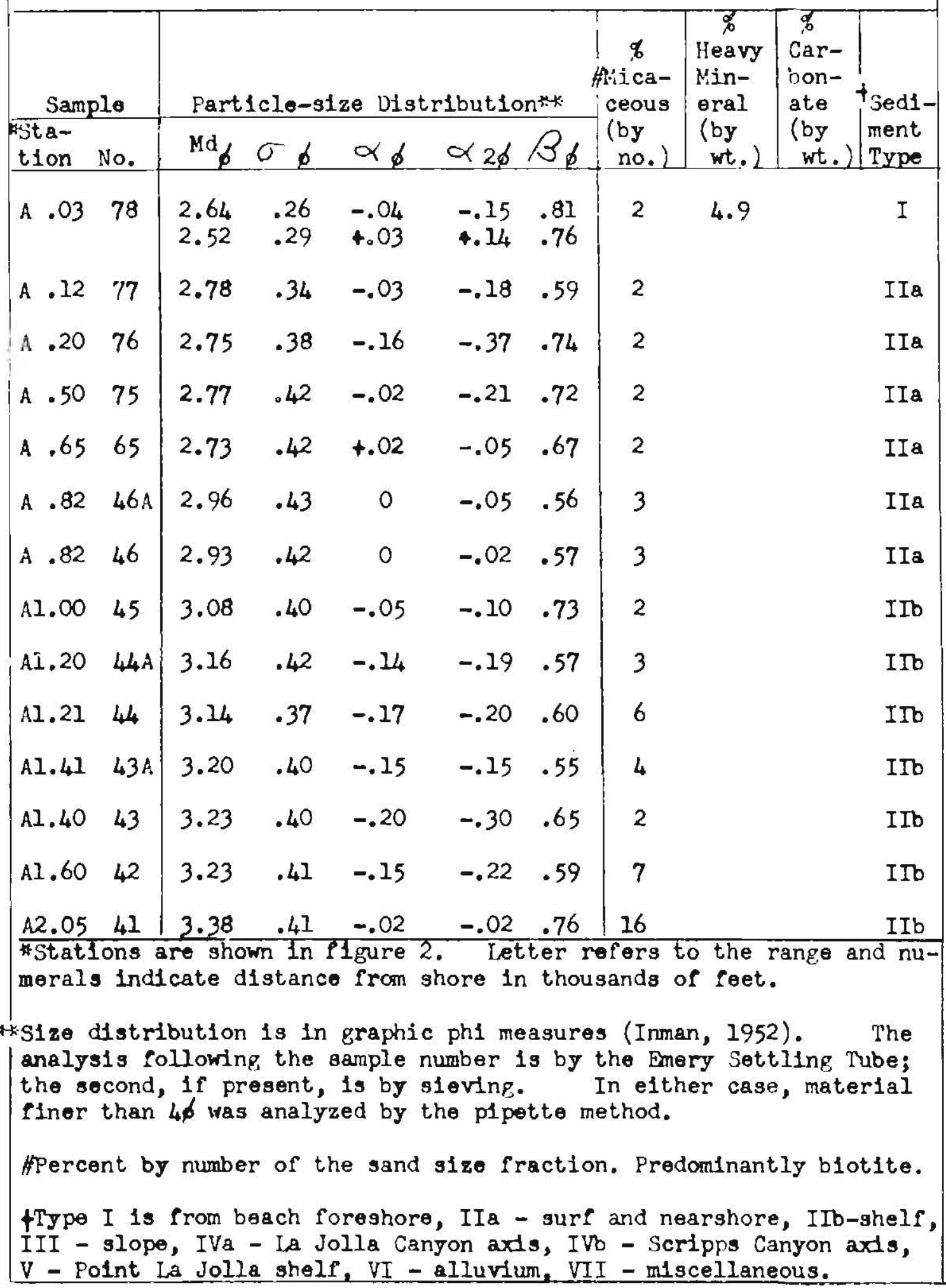




\begin{tabular}{|c|c|c|c|c|c|c|c|c|c|c|}
\hline \multirow{2}{*}{\multicolumn{2}{|c|}{$\begin{array}{l}\text { Sample } \\
\text { * Sta- } \\
\text { tran. No. }\end{array}$}} & \multicolumn{5}{|c|}{ Particle-size Distribution } & \multirow{2}{*}{ 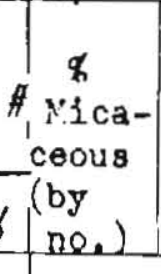 } & \multirow{2}{*}{ 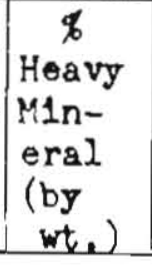 } & \multirow{2}{*}{$\begin{array}{l}\% \\
\text { Car- } \\
\text { bon- } \\
\text { ate } \\
\text { (by } \\
w t .)\end{array}$} & \multirow{2}{*}{$\begin{array}{l}\text { tSedi- } \\
\text { mont } \\
\text { Type }\end{array}$} \\
\hline & & $n d_{6}$ & $\sigma \phi$ & $\alpha \phi$ & $\alpha_{2 \phi}$ & $\beta_{\phi}$ & & & & \\
\hline$B .01$ & 86 & 2.56 & .26 & -.07 & -.27 & .62 & $<1$ & & & I \\
\hline B. .10 & 85 & $\begin{array}{l}2.72 \\
2.53\end{array}$ & $\begin{array}{l}.28 \\
.31\end{array}$ & $\begin{array}{r}-.14 \\
+.13\end{array}$ & $\begin{array}{r}-.02 \\
+.32\end{array}$ & $\begin{array}{l}.64 \\
.74\end{array}$ & $k 1$ & 5.3 & & I \\
\hline$B .15$ & 84 & 2.60 & .32 & 0 & 0 & .63 & $<2$ & & & IIa \\
\hline 8.25 & 83 & 2.56 & .42 & -.15 & -.29 & .90 & $<1$ & & & IIa \\
\hline B . 70 & 66 & 2.85 & .42 & -.05 & -.17 & .72 & 4 & & & $I_{a}$ \\
\hline B . 95 & 32 & 2.83 & .42 & +.02 & +.10 & .57 & 1 & & & $I_{a}$ \\
\hline 82.10 & 30 & 3.04 & .43 & -.05 &.$- u_{4}$ & .49 & 4 & & & ITb \\
\hline 32.22 & 29 & 3.12 & .41 & -.09 & -.19 & .65 & 2 & & & $I T \mathrm{~b}$ \\
\hline$B 2.40$ & 28 & 3.23 & .37 & -.11 & -.30 & .54 & 4 & & & I Tb \\
\hline 81.95 & 27 & 3.34 & .33 & -.12 & -.42 & .85 & 3 & & & ITb \\
\hline B2.25 & 26 & 3.27 & .36 &.- .17 & -.42 & .56 & 8 & & & I Tb \\
\hline B2.75 & 25 & 3.35 & .37 & -.03 & -.11 & .68 & 4 & & & IIb \\
\hline C. .02 & 90 & 2.45 & .25 & -.08 & -.48 & .80 & $k 1$ & & & I \\
\hline ic .08 & 89 & $\begin{array}{l}2.59 \\
2.42\end{array}$ & $\begin{array}{l}.22 \\
.28\end{array}$ & $\begin{array}{l}-.27 \\
+.04\end{array}$ & $\begin{array}{l}-.36 \\
+.07\end{array}$ & $\begin{array}{l}.65 \\
.78\end{array}$ & 1 & 4.8 & & I \\
\hline c . .25 & 88 & 2.71 & .33 & -.18 & -.18 & .79 & 2 & & & IIa \\
\hline c. .45 & 87 & 2.76 & .39 & -.03 & -.18 & .69 & 1 & & & IIa \\
\hline c . .80 & 67 & 2.83 & .47 & +.06 & +.02 & .53 & 5 & & & II 2 \\
\hline cl.10 & 24 & 2.83 & .41 & +.07 & 0 & .61 & 4 & & & $I T b$ \\
\hline $\mathrm{Cl} .40$ & 23 & 3.13 & .44 & -.04 & -.14 & .45 & 6 & & & $I I b$ \\
\hline $\mathrm{Cl} .50$ & 22 & 3.10 & .44 & -.04 & -.18 & .43 & & & & $I T b$ \\
\hline C2.00 & 21 & 3.26 & .33 & -.06 & -.21 & .79 & 3 & & & $I T b$ \\
\hline 62.95 & 20 & 3.25 & .39 & $=.15$ & -.28 & .62 & 2 & & & IIb \\
\hline
\end{tabular}


APPGIDIX IA (cont.)

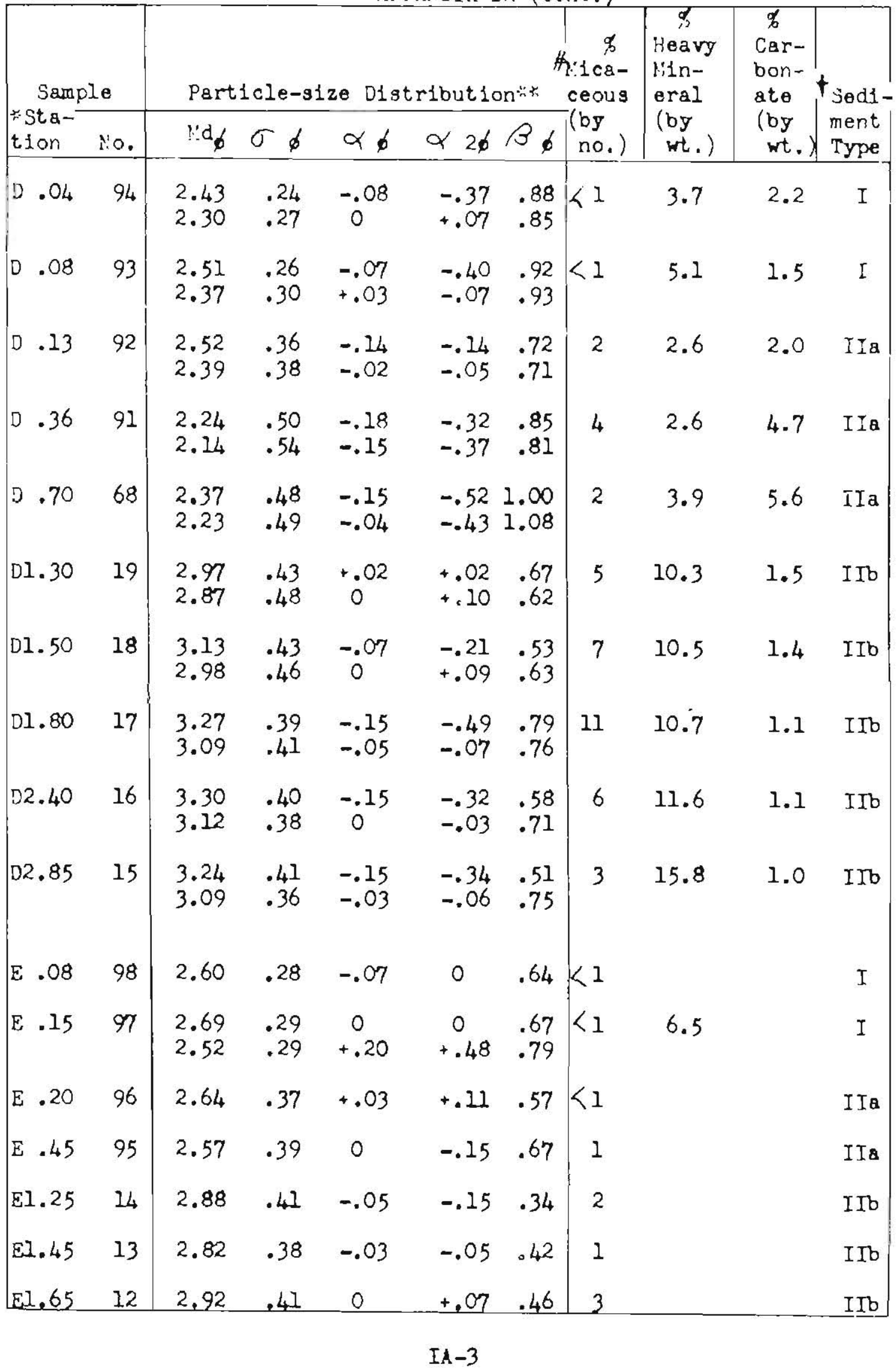


APPFANIX IA (cont.)

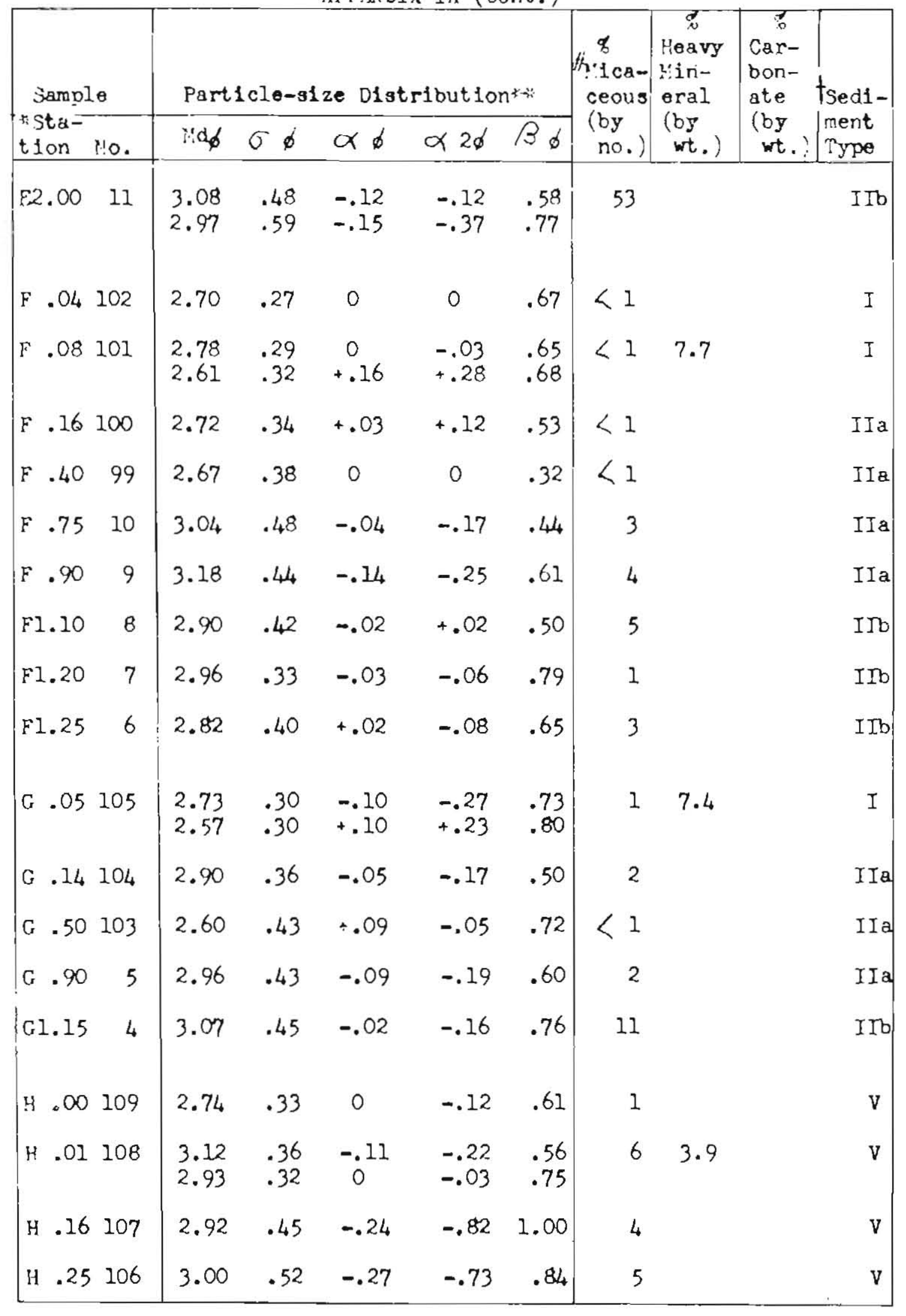


APPEIDIX IA (cont.)

\begin{tabular}{|c|c|c|c|c|c|c|c|c|c|c|}
\hline \multirow{2}{*}{\multicolumn{2}{|c|}{$\begin{array}{l}\text { Sample } \\
\text { * Sta- } \\
\text { tion No. }\end{array}$}} & \multicolumn{5}{|c|}{ Particle-size Dis } & \multirow{2}{*}{$\begin{array}{c}\% \\
\# \begin{array}{c}\% \text { ca- } \\
\text { ceous } \\
\text { (by } \\
\text { no. })\end{array}\end{array}$} & \multirow{2}{*}{$\begin{array}{c}\text { g } \\
\text { Meavy } \\
\text { Min- } \\
\text { eral } \\
\text { (by } \\
\text { wt.) }\end{array}$} & \multirow{2}{*}{$\begin{array}{l}\text { क } \\
\text { Car- } \\
\text { bon- } \\
\text { ate } \\
\text { (by } \\
\text { wt.) }\end{array}$} & \multirow{2}{*}{$\mid \begin{array}{l}\text { Sedi- } \\
\text { ment } \\
\text { Type }\end{array}$} \\
\hline & & $M d_{\phi}$ & $\sigma \phi$ & $\alpha \phi$ & $\alpha 2 \phi$ & $\beta_{\phi}$ & & & & \\
\hline $\mathrm{H} .60$ & 3 & 3.13 & .40 & 0 & -.02 & .65 & 4 & & & V \\
\hline $\mathrm{H} .90$ & 2 & 2.98 & .37 & -.05 & -.38 & .70 & 2 & & & $\mathbf{v}$ \\
\hline $\mathrm{HI}, 40$ & 1 & 2.25 & 1.04 & -.26 & -.70 & .83 & 5 & & & v \\
\hline$P .05$ & 82 & $\begin{array}{l}2.59 \\
2.41\end{array}$ & $\begin{array}{l}.24 \\
.28\end{array}$ & $\begin{array}{r}-.17 \\
+.04\end{array}$ & $\begin{array}{r}-.33 \\
+.21\end{array}$ & $\begin{array}{l}.75 \\
.71\end{array}$ & $<1$ & 7.8 & & I \\
\hline P. .10 & 81 & 2.60 & .31 & 0 & 0 & .64 & $<1$ & & & IIs \\
\hline$P .16$ & 80 & 2.73 & .37 & -.03 & -.18 & .54 & 1 & & & IIa \\
\hline$P .45$ & 79 & 2.63 & .46 & -.02 & 0 & .56 & 5 & & & IIa \\
\hline $\mathrm{Pl} .10$ & 36 & 2.88 & .44 & +.02 & +.09 & .59 & 4 & & & ITb \\
\hline P1.35 & 35 & 3.31 & .39 & -.15 & -.31 & .62 & 4 & & & ITb \\
\hline P1. 55 & 34 & 3.26 & .39 & -.10 & -.23 & .67 & 3 & & & ITb \\
\hline $\mathrm{Pl} .75$ & 33 & 3.34 & .32 & -.06 & -.38 & .81 & 4 & & & ITb \\
\hline $\mathrm{P} 2.25$ & 32 & 3.23 & .38 & -.05 & -.10 & .63 & 6 & & & ITb \\
\hline $\mathrm{p} 2.50$ & 47 & 3.70 & .62 & +.19 & +.62 & 1.02 & 11 & & & III \\
\hline $\mathrm{R} .25$ & 37 & 2.25 & .40 & +.30 & +.68 & .75 & 5 & & & IIa \\
\hline$R \cdot 40$ & 38 & 3.06 & .44 & -.05 & -.05 & .57 & 5 & & & ITb \\
\hline$R .55$ & 39 & 3.31 & .38 & -.10 & -.40 & .79 & 4 & & & ITb \\
\hline$R .70$ & 40 & 3.08 & .39 & -.03 & -.10 & .64 & 4 & & & ITb \\
\hline S. 55 & $55 \mathrm{~A}$ & 2.78 & .58 & -.03 & -.21 & .52 & 5 & & & IIa \\
\hline 3.57 & 55 & 2.79 & .55 & +.02 & -.07 & .62 & 4 & & & IIa \\
\hline j.73 & 54 & 3.12 & .53 & -.21 & -.42 & .49 & 7 & & & IIa \\
\hline
\end{tabular}


APPENDIX IA (cent.)

\begin{tabular}{|c|c|c|c|c|c|c|c|c|c|c|}
\hline \multirow{2}{*}{\multicolumn{2}{|c|}{$\begin{array}{l}\text { Samplo } \\
\text { Sta- } \\
\text { tion No. }\end{array}$}} & \multicolumn{5}{|c|}{ Porticlo-size Distribution*t } & \multirow{2}{*}{$\begin{array}{c}\% \\
\text { \#pica- } \\
\text { ceous } \\
\text { (by } \\
\text { no. })\end{array}$} & \multirow{2}{*}{$\begin{array}{l}\text { क } \\
\text { Heavy } \\
\text { Min- } \\
\text { eral } \\
\text { (by } \\
\text { wt.) }\end{array}$} & \multirow{2}{*}{\multicolumn{2}{|c|}{$\begin{array}{l}\% \\
\text { Car- } \\
\text { bon- } \\
\text { ste } \\
\text { (by } \\
\text { wt.)? }\end{array}$}} \\
\hline & & $\mathrm{Md}$ & $\sigma \phi$ & of 6 & $Y 2 \phi$ & $\Omega_{\phi}$ & & & & \\
\hline S.78 & 53 & 3.26 & .43 & -.28 & -.47 & .60 & 10 & & & I Ia \\
\hline 5.85 & 52 & 3.25 & .44 & -.09 & -.03 & .75 & 25 & & & II 8 \\
\hline $\mathrm{S1.02}$ & 51 & 3.19 & .45 & -.16 & -.13 & .71 & 15 & & & VII \\
\hline 51.25 & 50 & 3.18 & .44 & -.16 & -.20 & .57 & 7 & & & VII \\
\hline U . 90 & 72 & 2.51 & .44 & +.02 & +.09 & .64 & 4 & & & II a \\
\hline U1.12 & 71 & 3.10 & .45 & -.09 & -.31 & .56 & 7 & & & IIb \\
\hline U1. 45 & 64 & 3.11 & .54 & -.15 & -.35 & .59 & 2 & & & IIb \\
\hline U1. 55 & 70 & 3.42 & .43 & -.19 & -.42 & .63 & 3 & & & IIb \\
\hline U1.85 & 63 & 3.35 & .45 & -.20 & -.49 & .73 & 3 & & & IIb \\
\hline$U 2.30$ & 62 & 3.48 & .36 & -.06 & -.33 & .75 & 5 & & & IIb \\
\hline U2. 90 & 61 & 3.50 & .40 & -.18 & -.37 & .60 & 3 & & & I Ib \\
\hline V. 85 & 60 & 3.00 & .53 & -.13 & -.26 & .51 & 4 & & & IIa \\
\hline V1.05 & 59 & 3.06 & .46 & -.15 & -.32 & .65 & 4 & & & VII \\
\hline V1.15 & 58 & 3.11 & .46 & -.15 & -.26 & .59 & 16 & & & VII \\
\hline V1.25 & 57 & 3.08 & .46 & -.09 & -.15 & .69 & 12 & & & VII \\
\hline V1. 45 & 56 & 3.27 & .40 & -.10 & -.15 & .67 & 3 & & & VII \\
\hline
\end{tabular}




\begin{tabular}{|c|c|c|c|c|c|c|c|c|c|}
\hline 2 & -26 & Augugt & $\begin{array}{r}\text { APPE } \\
1949 \mathrm{~B}\end{array}$ & $\begin{array}{l}\text { PDIX II } \\
\text { each an }\end{array}$ & d Bott & Com Sed & Iments & & \\
\hline Samplo & Part1 & cle-81z & ze D1st & ribut10 & nis: & $\begin{array}{c}q \\
k: 1 \text { ca- } \\
\text { ceous }\end{array}$ & $\begin{array}{c}q \\
\text { Heavy } \\
\text { Hin- } \\
\text { ersl }\end{array}$ & $\begin{array}{l}q \\
\text { Car- } \\
\text { bon- } \\
\text { ato }\end{array}$ & tsods- \\
\hline $\begin{array}{l}\text { Nota- } \\
\text { tion } \quad \text { No. }\end{array}$ & ${ }^{H d} d C$ & $\Gamma \phi$ & $\alpha \phi$ & $\alpha 2 \phi$ & Bos & $\begin{array}{c}\text { (by } \\
\text { ne. })\end{array}$ & $\begin{array}{c}\text { (by } \\
\text { bta) }\end{array}$ & (by & $\begin{array}{l}\text { ment } \\
\text { Txpee }\end{array}$ \\
\hline$\wedge .04 \quad 127$ & $\begin{array}{l}2.80 \\
2.68\end{array}$ & $\begin{array}{l}.25 \\
.34\end{array}$ & $\begin{array}{l}0 \\
0\end{array}$ & $\begin{array}{l}-.08 \\
-.06\end{array}$ & $\begin{array}{l}.80 \\
.70\end{array}$ & $<1$ & 16.1 & 1.2 & $I$ \\
\hline A . $.22 \quad 128$ & $\begin{array}{l}2.78 \\
2.58\end{array}$ & $\begin{array}{l}.34 \\
.40\end{array}$ & $\begin{array}{c}-.03 \\
0\end{array}$ & $\begin{array}{l}-.06 \\
-.05\end{array}$ & $\begin{array}{l}.77 \\
.70\end{array}$ & 3 & 2.2 & 1.7 & IIa \\
\hline$\Lambda .48 \quad 32$ & $\begin{array}{l}3.06 \\
2.91\end{array}$ & $\begin{array}{l}.43 \\
.48\end{array}$ & $\begin{array}{l}-.16 \\
-.15\end{array}$ & $\begin{array}{l}-.28 \\
-.32\end{array}$ & $\begin{array}{l}.58 \\
.71\end{array}$ & 5 & 7.4 & .8 & IIs \\
\hline A. .70 & $\begin{array}{l}2.75 \\
2.67\end{array}$ & $\begin{array}{l}.47 \\
.51\end{array}$ & +.14 & $\begin{array}{r}+.15 \\
-.02\end{array}$ & $\begin{array}{l}.60 \\
.68\end{array}$ & 2 & 7.9 & .6 & IIe \\
\hline A . .82 & $\begin{array}{l}2.90 \\
2.83\end{array}$ & $\begin{array}{l}.58 \\
.48\end{array}$ & $\begin{array}{l}-.02 \\
+.02\end{array}$ & $\begin{array}{l}+.07 \\
+.04\end{array}$ & $\begin{array}{l}.31 \\
.64\end{array}$ & 2 & 11.1 & .6 & IIa \\
\hline A1.00 & $\begin{array}{l}3.23 \\
3.08\end{array}$ & $\begin{array}{l}.40 \\
.41\end{array}$ & $\begin{array}{l}-.12 \\
-.07\end{array}$ & $\begin{array}{l}-.20 \\
-.07\end{array}$ & $\begin{array}{l}.52 \\
.73\end{array}$ & 3 & 12.9 & .8 & IIb \\
\hline Al.20 & $\begin{array}{l}3.31 \\
3.07\end{array}$ & $\begin{array}{l}.40 \\
.40\end{array}$ & $\begin{array}{l}-.27 \\
-.05\end{array}$ & $\begin{array}{l}-.40 \\
-.05\end{array}$ & $\begin{array}{l}.52 \\
.72\end{array}$ & 4 & 16.2 & .7 & ITb \\
\hline A1.35 & $\begin{array}{l}3.26 \\
3.13\end{array}$ & $\begin{array}{l}.38 \\
.38\end{array}$ & $\begin{array}{l}-.11 \\
-.03\end{array}$ & $\begin{array}{r}-.18 \\
+.03\end{array}$ & $\begin{array}{l}.58 \\
.74 \times+4\end{array}$ & 3 & 14.0 & .4 & IIb \\
\hline Al. 65 & $\begin{array}{l}3.26 \\
3.13\end{array}$ & $\begin{array}{l}.39 \\
.40\end{array}$ & $\begin{array}{l}-.10 \\
-.02\end{array}$ & $\begin{array}{l}-.15 \\
-.17\end{array}$ & $\begin{array}{l}.56 \\
.77\end{array}$ & 6 & 9.2 & .4 & IIb \\
\hline A2.05 & $\begin{array}{l}3.18 \\
3.03\end{array}$ & $\begin{array}{l}.39 \\
.40\end{array}$ & $\begin{array}{r}-.18 \\
+.02\end{array}$ & $\begin{array}{l}-.28 \\
+.07\end{array}$ & $\begin{array}{l}.60 \\
.72\end{array}$ & 4 & 13.1 & 1.1 & ITb \\
\hline A2.25 & $\begin{array}{l}3.37 \\
3.17\end{array}$ & $\begin{array}{l}.37 \\
.37\end{array}$ & $\begin{array}{l}-.19 \\
-.06\end{array}$ & $\begin{array}{l}-.30 \\
-.08\end{array}$ & $\begin{array}{l}.49 \\
.86\end{array}$ & 14 & 9.5 & .9 & ITb \\
\hline B $.04 \quad 118$ & $\begin{array}{l}2.60 \\
2.54\end{array}$ & $\begin{array}{l}.25 \\
.34\end{array}$ & $\begin{array}{l}0 \\
0\end{array}$ & $\begin{array}{l}0 \\
0\end{array}$ & $\begin{array}{l}.67 \\
.65\end{array}$ & 1 & 18.6 & 1.8 & $I$ \\
\hline
\end{tabular}


APPITDIX IR (cont.)

\begin{tabular}{|c|c|c|c|c|c|c|c|c|c|c|}
\hline Samp] & & Part & Lele-g & & Lbutio & . & 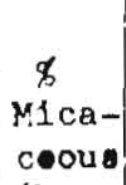 & $\begin{array}{c}\% \\
\text { Heavy } \\
\text { rin- } \\
\text { eral }\end{array}$ & $\begin{array}{l}\text { 思 } \\
\text { Car- } \\
\text { bon- } \\
\text { ate }\end{array}$ & $t_{\text {ied } 1-}$ \\
\hline $\begin{array}{l}\text { * sta- } \\
\text { t1en }\end{array}$ & Ne. & $l^{\prime} d$ & $\sigma$ & $\alpha \phi$ & $\times \quad 2 \phi$ & $\Theta \phi$ & $\begin{array}{c}\text { (by } \\
\text { no.) }\end{array}$ & $\begin{array}{l}\text { (by } \\
\text { wt.) }\end{array}$ & $\begin{array}{c}\text { (by } \\
w t .)\end{array}$ & $\begin{array}{l}\text { ment } \\
\text { Type }\end{array}$ \\
\hline B. 18 & 119 & $\begin{array}{l}2.45 \\
2.34\end{array}$ & $\begin{array}{l}.34 \\
.40\end{array}$ & $\begin{array}{c}0 \\
+.05\end{array}$ & $\begin{array}{l}0 \\
+.10\end{array}$ & $\begin{array}{l}.67 \\
.80\end{array}$ & $<1$ & 2.7 & 2.3 & II a \\
\hline B. 45 & 120 & $\begin{array}{l}2.65 \\
2.52\end{array}$ & $\begin{array}{l}.45 \\
.50\end{array}$ & $\begin{array}{l}0 \\
0\end{array}$ & $\begin{array}{l}-.18 \\
-.18\end{array}$ & $\begin{array}{l}.76 \\
.82\end{array}$ & 1 & 4.4 & 2.6 & IIa \\
\hline B. .50 & 34 & $\begin{array}{l}2.70 \\
2.63\end{array}$ & $\begin{array}{l}.45 \\
.50\end{array}$ & $\begin{array}{c}-.02 \\
0\end{array}$ & $\begin{array}{l}-.04 \\
-.06\end{array}$ & $\begin{array}{l}.58 \\
.72\end{array}$ & 1 & 12.8 & 1.5 & IIa \\
\hline$B 1 . \infty$ & 73 & $\begin{array}{l}2.88 \\
2.87\end{array}$ & $\begin{array}{l}.49 \\
.49\end{array}$ & $\begin{array}{c}+.02 \\
0\end{array}$ & $0^{+.14}$ & $\begin{array}{l}.45 \\
.65\end{array}$ & 3 & 14.9 & .8 & II a \\
\hline B1.12 & 74 & $\begin{array}{l}3.14 \\
3.00\end{array}$ & .44 & $\begin{array}{c}-.09 \\
0\end{array}$ & $\begin{array}{l}-.14 \\
-.02\end{array}$ & $\begin{array}{l}.54 \\
.67\end{array}$ & 5 & 13.0 & .9 & IIb \\
\hline$B 1.22$ & 75 & $\begin{array}{l}3.20 \\
3.10\end{array}$ & $\begin{array}{l}.43 \\
.41\end{array}$ & $\begin{array}{l}-.19 \\
-.02\end{array}$ & $\begin{array}{l}-.19 \\
-.05\end{array}$ & $\begin{array}{l}.44 \\
.71\end{array}$ & 3 & 16.4 & .9 & ITb \\
\hline$B 1.40$ & 76 & $\begin{array}{l}3.25 \\
3.15\end{array}$ & $\begin{array}{r}.41 \\
.39\end{array}$ & -.10 & $\begin{array}{l}-.05 \\
-.05\end{array}$ & $\begin{array}{r}.51 \\
.72\end{array}$ & 2 & 17.5 & .8 & I Io \\
\hline 81.95 & 77 & $\begin{array}{l}3.34 \\
3.17\end{array}$ & $\begin{array}{l}.37 \\
.38\end{array}$ & $\begin{array}{l}-.16 \\
-.03\end{array}$ & $\begin{array}{l}-.38 \\
-.08\end{array}$ & $\begin{array}{l}.65 \\
.74\end{array}$ & 5 & 9.3 & .7 & IIb \\
\hline 32.25 & 78 & $\begin{array}{l}3.34 \\
3.16\end{array}$ & $\begin{array}{r}.38 \\
.38\end{array}$ & -16 & $\begin{array}{l}-.24 \\
-.03\end{array}$ & $\begin{array}{r}.50 \\
.71\end{array}$ & 4 & 10.7 & 1.2 & ITb \\
\hline 82.90 & 79 & $\begin{array}{l}3.42 \\
3.23\end{array}$ & $\begin{array}{l}.37 \\
.35\end{array}$ & $\begin{array}{c}-.11 \\
0\end{array}$ & $\begin{array}{r}-.11 \\
+.03\end{array}$ & $\begin{array}{l}.57 \\
.86\end{array}$ & 3 & 12.0 & 1.3 & IIb \\
\hline B3.60 & 80 & $\begin{array}{l}3.75 \\
3.53\end{array}$ & $\begin{array}{l}.40 \\
.44\end{array}$ & $\begin{array}{l}+.02 \\
+.07\end{array}$ & $\begin{array}{l}+.47 \\
+.48\end{array}$ & $\begin{array}{l}1.07 \\
1.09\end{array}$ & 13 & 6.0 & 1.9 & ITb \\
\hline c. .03 & 121 & $\begin{array}{l}2.56 \\
2.42\end{array}$ & $\begin{array}{l}.25 \\
.32\end{array}$ & $\begin{array}{l}-.08 \\
+.13\end{array}$ & $\begin{array}{r}-.16 \\
+.38\end{array}$ & $\begin{array}{l}.76 \\
.75\end{array}$ & 1 & 15.5 & 1.8 & I \\
\hline c. . 20 & 122 & $\begin{array}{l}2.53 \\
2.48\end{array}$ & $\begin{array}{r}.48 \\
.58\end{array}$ & $\begin{array}{l}-.08 \\
-.10\end{array}$ & $\begin{array}{l}-.23 \\
-.55\end{array}$ & $\begin{array}{r}.71 \\
1.02\end{array}$ & 6 & 7.3 & 3.0 & II a \\
\hline c. .48 & 123 & $\begin{array}{l}2.75 \\
2.58\end{array}$ & $\begin{array}{l}.53 \\
.58\end{array}$ & $\begin{array}{c}-.08 \\
0\end{array}$ & $\begin{array}{l}-.21 \\
-.10\end{array}$ & $\begin{array}{l}.60 \\
0.79\end{array}$ & 4 & 5.2 & 4.2 & II \\
\hline
\end{tabular}


APPDNIX IB (cont.)

\begin{tabular}{|c|c|c|c|c|c|c|c|c|c|c|}
\hline \multirow{2}{*}{\multicolumn{2}{|c|}{$\begin{array}{l}\text { Sample } \\
\text { * Sta }= \\
\text { t1on No. }\end{array}$}} & \multicolumn{5}{|c|}{ Particle-s1ze Distribution } & \multirow{2}{*}{$\mid \begin{array}{c}n \\
\text { cea- } \\
\text { ceous } \\
\text { by } \\
\text { no. })\end{array}$} & \multirow{2}{*}{$\begin{array}{l}c \\
\text { Heavy } \\
\text { Min- } \\
\text { eral } \\
\text { (by } \\
\text { wt.) }\end{array}$} & \multirow{2}{*}{$\begin{array}{l}\text { of } \\
\text { Car- } \\
\text { bon- } \\
\text { ate } \\
\text { (by } \\
\text { wt.) }\end{array}$} & \multirow{2}{*}{$\begin{array}{l}\text { Tsed1- } \\
\text { mont } \\
\text { Type }\end{array}$} \\
\hline & & Nide & $\sigma \phi$ & $\alpha \phi$ & $\alpha 26$ & $\beta \phi$ & & & & \\
\hline C. .60 & 35 & $\begin{array}{l}2.87 \\
2.72\end{array}$ & $\begin{array}{l}.41 \\
.46\end{array}$ & -.10 & $\begin{array}{l}-.05 \\
-.02\end{array}$ & $\begin{array}{l}.51 \\
.76\end{array}$ & 4 & 15.9 & 1.4 & IIa \\
\hline C1. $\infty$ & 72 & $\begin{array}{l}2.67 \\
2.72\end{array}$ & $\begin{array}{l}.50 \\
.52\end{array}$ & +.20 & $\begin{array}{l}+.20 \\
-.06\end{array}$ & $\begin{array}{l}.54 \\
.67\end{array}$ & 4 & 9.0 & 1.0 & IIa \\
\hline $\mathrm{Cl} .40$ & 71 & $\begin{array}{l}3.15 \\
3.03\end{array}$ & $\begin{array}{l}.41 \\
.43\end{array}$ & $\begin{array}{l}-.15 \\
-.05\end{array}$ & $\begin{array}{l}-.02 \\
-.02\end{array}$ & $\begin{array}{l}.59 \\
.67\end{array}$ & 3 & 15.3 & 1.0 & IIb \\
\hline $\mathrm{C} 2.00$ & 70 & $\begin{array}{l}3.31 \\
3.13\end{array}$ & $\begin{array}{l}.39 \\
.40\end{array}$ & $\begin{array}{l}-.20 \\
-.02\end{array}$ & $\begin{array}{l}-.20 \\
-.12\end{array}$ & $\begin{array}{l}.54 \\
.75\end{array}$ & 2 & 5.2 & 1.5 & ITb \\
\hline $\mathrm{C} 2.95$ & 69 & $\begin{array}{l}3.23 \\
3.07\end{array}$ & $\begin{array}{l}.42 \\
.42\end{array}$ & $\begin{array}{l}-.17 \\
-.07\end{array}$ & $\begin{array}{l}-.33 \\
-.17\end{array}$ & .64 & $<1$ & 16.0 & .9 & $I I b$ \\
\hline$c 3.50$ & 68 & $\begin{array}{l}3.17 \\
3.12\end{array}$ & $\begin{array}{l}.45 \\
.41\end{array}$ & $\begin{array}{c}-.09 \\
0\end{array}$ & $\begin{array}{l}-.16 \\
-.05\end{array}$ & $\begin{array}{l}.53 \\
.76\end{array}$ & 1 & 13.9 & .3 & I I b \\
\hline $\mathrm{C} 4.40$ & 67 & $\begin{array}{l}3.52 \\
3.51\end{array}$ & $\begin{array}{l}1.27 \\
1.00\end{array}$ & $\begin{array}{l}+.40 \\
+.64\end{array}$ & $\begin{array}{l}+1.31 \\
+2.11\end{array}$ & $\begin{array}{l}1.51 \\
1.75\end{array}$ & 10 & 3.6 & $3 \cdot 3$ & III \\
\hline D. .08 & 114 & $\begin{array}{l}2.58 \\
2.40\end{array}$ & $\begin{array}{l}.24 \\
.30\end{array}$ & $\begin{array}{l}-.08 \\
+.17\end{array}$ & $\begin{array}{l}-.17 \\
+.30\end{array}$ & $\begin{array}{r}.58 \\
.63\end{array}$ & $<1$ & 7.1 & 1.5 & I \\
\hline D .17 & 3.17 & $\begin{array}{l}2.68 \\
2.50\end{array}$ & $\begin{array}{l}.31 \\
.32\end{array}$ & $\begin{array}{l}-.03 \\
+.06\end{array}$ & $\begin{array}{l}-.09 \\
+.06\end{array}$ & .61 & 2 & 1.7 & 1.8 & IIa \\
\hline D .22 & 115 & $\begin{array}{l}2.65 \\
2.50\end{array}$ & $\begin{array}{l}.39 \\
.40\end{array}$ & $\begin{array}{l}0 \\
0\end{array}$ & $\begin{array}{l}-.08 \\
+.05\end{array}$ & $\begin{array}{l}.59 \\
.65\end{array}$ & 5 & 3.3 & 2.4 & $\operatorname{IIa}$ \\
\hline D. .50 & 36 & $\begin{array}{l}2.56 \\
2.45\end{array}$ & .44 & $\begin{array}{c}0 \\
+.02\end{array}$ & $\begin{array}{c}0 \\
-.04\end{array}$ & $\begin{array}{l}.65 \\
.70\end{array}$ & 2 & 4.1 & 2.1 & $\operatorname{IIa}$ \\
\hline D. .60 & 116 & $\begin{array}{l}2.62 \\
2.50\end{array}$ & $\begin{array}{l}.48 \\
.48\end{array}$ & $\begin{array}{l}-.04 \\
-.04\end{array}$ & $\begin{array}{l}-.12 \\
-.23\end{array}$ & $\begin{array}{l}.69 \\
.90\end{array}$ & 1 & 6.4 & 3.2 & IIa \\
\hline D1.25 & 60 & $\begin{array}{l}3.02 \\
2.87\end{array}$ & .42 & $\begin{array}{c}0 \\
+.02\end{array}$ & $\begin{array}{c}0 \\
+.06\end{array}$ & $\begin{array}{l}.65 \\
.59\end{array}$ & 5 & 10.7 & 1.7 & $I I b$ \\
\hline 01.50 & 61 & $\begin{array}{l}3.13 \\
3.00\end{array}$ & $\begin{array}{l}.44 \\
.45\end{array}$ & -.11 & $\begin{array}{l}-.16 \\
+.06\end{array}$ & $\begin{array}{l}.56 \\
.67\end{array}$ & 3 & 11.8 & 1.4 & Ino \\
\hline D1. 80 & 62 & $\begin{array}{r}3.30 \\
3.10\end{array}$ & $\begin{array}{l}.39 \\
.42 \\
\end{array}$ & $\begin{array}{c}0 \\
-.05\end{array}$ & $\begin{array}{l}-.20 \\
-.19\end{array}$ & $\begin{array}{l}.65 \\
.80 \\
\end{array}$ & 9 & 11.1 & 3.1 & $\operatorname{Irb}$ \\
\hline
\end{tabular}

IB-3 


\begin{tabular}{|c|c|c|c|c|c|c|c|c|c|c|}
\hline \multirow{2}{*}{\multicolumn{2}{|c|}{$\begin{array}{l}\text { Sample } \\
\text { * Sta } \\
\text { t1on No }\end{array}$}} & \multicolumn{5}{|c|}{ Particle-size D1: } & \multirow{2}{*}{$\begin{array}{c}g^{\prime} \\
\text { Nilca- } \\
\text { ceous } \\
\text { (by } \\
\text { no.) }\end{array}$} & \multirow{2}{*}{$\begin{array}{l}\text { } \\
\text { Heavy } \\
\text { Nin- } \\
\text { oral } \\
\text { (by } \\
\text { wt.) }\end{array}$} & \multirow{2}{*}{$\begin{array}{c}0 \\
\text { Car- } \\
\text { bon- } \\
\text { ste } \\
\text { (by } \\
\text { wt. })\end{array}$} & \multirow{2}{*}{$\begin{array}{l}\text { ted1- } \\
\text { ment } \\
\text { Type }\end{array}$} \\
\hline & & $N d_{\alpha}$ & $\sigma \phi$ & $\alpha \phi$ & $\alpha 2 \phi$ & $\theta \phi$ & & & & \\
\hline 102.40 & 63 & $\begin{array}{l}3.31 \\
3.10\end{array}$ & $\begin{array}{r}.40 \\
.39\end{array}$ & $\begin{array}{l}-.02 \\
-.02\end{array}$ & $\begin{array}{l}-.32 \\
-.13\end{array}$ & $\begin{array}{l}.62 \\
.79\end{array}$ & 7 & 10.8 & 1.4 & ITO \\
\hline 02.85 & 64 & $\begin{array}{l}3.24 \\
3.07\end{array}$ & $\begin{array}{l}.39 \\
.39\end{array}$ & $\begin{array}{l}-.08 \\
-.02\end{array}$ & $\begin{array}{l}-.11 \\
+.02\end{array}$ & $\begin{array}{l}.66 \\
.80\end{array}$ & 2 & 13.7 & .9 & ITO \\
\hline 03.75 & 65 & $\begin{array}{l}3.28 \\
3.05\end{array}$ & $\begin{array}{l}.40 \\
.42\end{array}$ & $\begin{array}{l}-.08 \\
-.02\end{array}$ & $\begin{array}{l}-.10 \\
+.02\end{array}$ & $\begin{array}{l}.60 \\
.67\end{array}$ & 1 & $\mu_{4} .8$ & .9 & ITO \\
\hline 04.25 & 66 & $\begin{array}{l}3.56 \\
3.37\end{array}$ & $\begin{array}{r}.41 \\
.45\end{array}$ & $\begin{array}{l}+.02 \\
+.09\end{array}$ & $\begin{array}{l}+.31 \\
+.53\end{array}$ & $\begin{array}{l}.97 \\
.98\end{array}$ & 6 & 7.7 & 1.4 & IIO \\
\hline$E .09$ & 110 & $\begin{array}{l}2.72 \\
2.43\end{array}$ & $\begin{array}{r}.25 \\
.32\end{array}$ & $\begin{array}{r}-.08 \\
+.03\end{array}$ & $\begin{array}{r}-.08 \\
+.19\end{array}$ & $\begin{array}{l}.60 \\
.88\end{array}$ & 2 & 17.0 & 2.8 & I \\
\hline$E .24$ & 111 & $\begin{array}{l}2.56 \\
2.37\end{array}$ & .31 & $\begin{array}{r}+.03 \\
+.03\end{array}$ & $\begin{array}{l}+.10 \\
+.12\end{array}$ & $\begin{array}{l}.61 \\
.73\end{array}$ & 2 & 2.2 & 4.2 & I I a \\
\hline T. 32 & 113 & $\begin{array}{l}2.62 \\
2.39\end{array}$ & $\begin{array}{r}.32 \\
.36\end{array}$ & $\begin{array}{r}-.03 \\
+.11\end{array}$ & $\begin{array}{r}-.03 \\
+.17\end{array}$ & $\begin{array}{l}.66 \\
.78\end{array}$ & 2 & 5.8 & 2.8 & IIa \\
\hline 5.45 & 37 & $\begin{array}{l}2.54 \\
2.45\end{array}$ & $\begin{array}{l}.34 \\
.40\end{array}$ & $\begin{array}{r}+.03 \\
+.08\end{array}$ & $\begin{array}{l}-.03 \\
+.08\end{array}$ & $\begin{array}{r}.91 \\
.75\end{array}$ & $<1$ & 2.0 & 2.2 & IIa \\
\hline$\therefore .55$ & 112 & $\begin{array}{l}2.51 \\
2.35\end{array}$ & $\begin{array}{l}.41 \\
.44\end{array}$ & $\begin{array}{l}+.02 \\
+.07\end{array}$ & $\begin{array}{l}+.10 \\
+.02\end{array}$ & $\begin{array}{l}.76 \\
.73\end{array}$ & 2 & 3.1 & 3.7 & IIa \\
\hline El.25 & 59 & $\begin{array}{l}2.98 \\
2.83\end{array}$ & $\begin{array}{r}.47 \\
.45\end{array}$ & -.12 & $0^{-.02}$ & $\begin{array}{l}.47 \\
.65\end{array}$ & 2 & 12.3 & 1.5 & IIb \\
\hline$\because 1.65$ & 58 & $\begin{array}{l}2.85 \\
2.74\end{array}$ & $\begin{array}{l}.38 \\
.44\end{array}$ & $\begin{array}{c}-.02 \\
0\end{array}$ & $\begin{array}{l}0 \\
0\end{array}$ & $\begin{array}{r}.52 \\
.65\end{array}$ & 2 & 9.9 & 1.0 & IT \\
\hline$F=2.00$ & 57 & $\begin{array}{l}3.02 \\
2.81\end{array}$ & $\begin{array}{l}.43 \\
.68\end{array}$ & $\begin{array}{l}-.16 \\
-.13\end{array}$ & $\begin{array}{l}-.21 \\
-.22\end{array}$ & $\begin{array}{l}.65 \\
.61\end{array}$ & 40 & 6.8 & 5.1 & I Ib \\
\hline$\because 2.80$ & 56 & $\begin{array}{l}3.01 \\
2.74\end{array}$ & $\begin{array}{r}.39 \\
.45\end{array}$ & $\begin{array}{l}-.03 \\
-.02\end{array}$ & $\begin{array}{l}-.09 \\
-.04\end{array}$ & $\begin{array}{l}.58 \\
.64\end{array}$ & 4 & 8.3 & 2.1 & IIb \\
\hline$\$ 3.40$ & 55 & $\begin{array}{l}3.07 \\
2.89\end{array}$ & $\begin{array}{r}.42 \\
.42\end{array}$ & $\begin{array}{l}+.02 \\
+.02\end{array}$ & $\begin{array}{l}+.10 \\
+.07\end{array}$ & $\begin{array}{l}.60 \\
.66\end{array}$ & 2 & 13.1 & 1.1 & ITb \\
\hline $\mathrm{F}_{4} .60$ & 54 & $\begin{array}{l}3.66 \\
3.47\end{array}$ & $\begin{array}{r}.71 \\
.64\end{array}$ & $\begin{array}{r}+.07 \\
+.38 \\
\end{array}$ & $\begin{array}{l}+.69 \\
1.17\end{array}$ & $\begin{array}{l}1.08 \\
1.22\end{array}$ & 8 & 8.0 & 3.3 & III \\
\hline
\end{tabular}


APPONIIX IB (cont.)

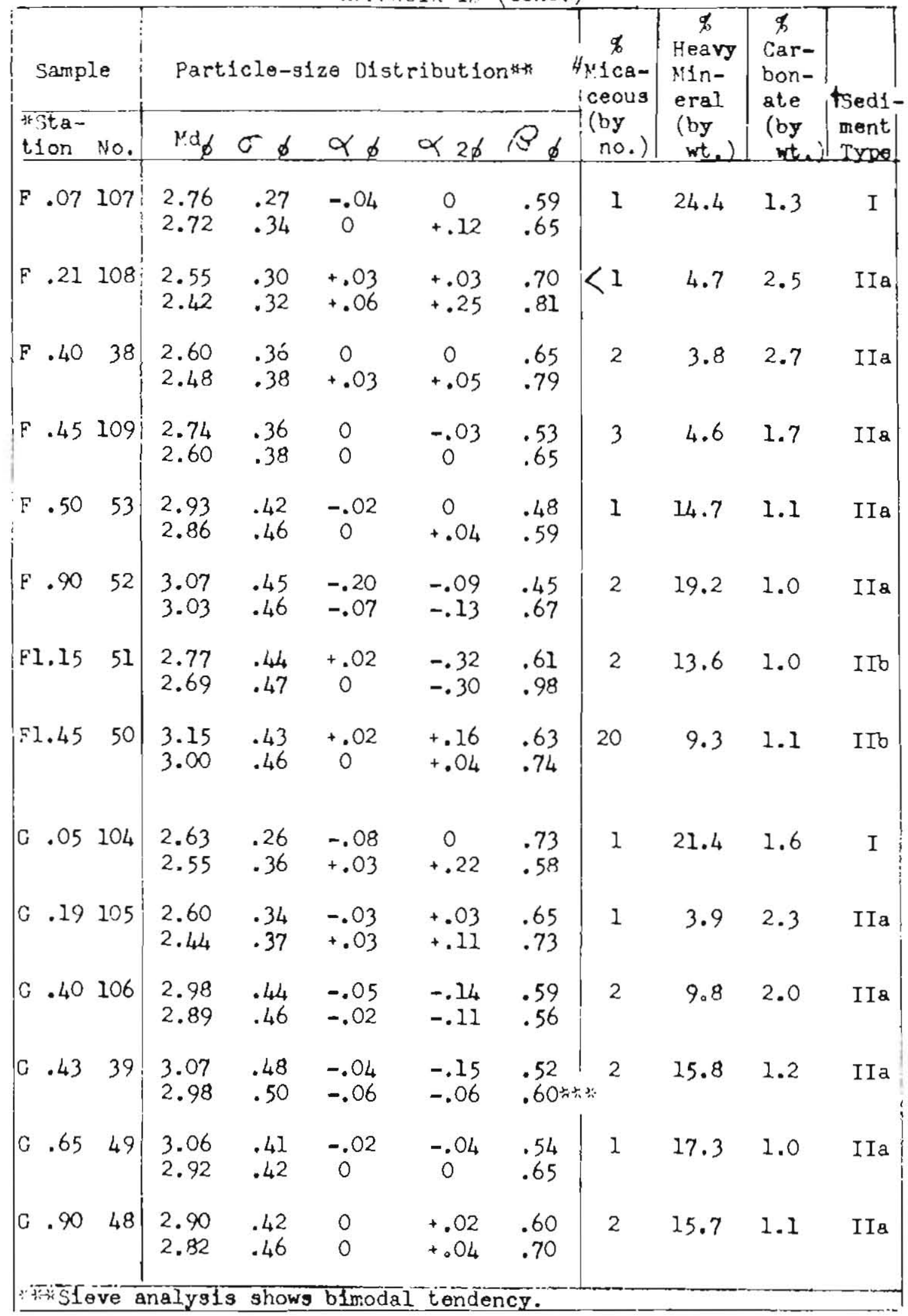

IB-5 
APPQSIDIX IB (cont.)

\begin{tabular}{|c|c|c|c|c|c|c|c|c|c|c|}
\hline \multirow{2}{*}{\multicolumn{2}{|c|}{$\begin{array}{l}\text { Sample } \\
\text { sta- } \\
\text { tion No. }\end{array}$}} & \multicolumn{5}{|c|}{ Particle-size Distribution:ist } & \multirow{2}{*}{$\begin{array}{c}\text { [ } \\
\text { thysca } \\
\text { ceous } \\
\text { (by } \\
\text { no. })\end{array}$} & \multirow{2}{*}{$\begin{array}{l}\text { os } \\
\text { Heavy } \\
\text { rin- } \\
\text { eral } \\
\text { (by } \\
\text { wt.) }\end{array}$} & \multirow{2}{*}{$\begin{array}{c}\text { b } \\
\text { Car- } \\
\text { bon- } \\
\text { ate } \\
\text { (by } \\
\text { wt. }\end{array}$} & \multirow{2}{*}{$\begin{array}{c}\text { Tsedt } \\
\text { ment } \\
\text { Type }\end{array}$} \\
\hline & & $\because 0_{6}$ & $\sigma \phi$ & $\propto \phi$ & $\propto 2 \phi$ & $\theta_{\phi}$ & & & & \\
\hline G1.10 & 47 & $\begin{array}{l}2.90 \\
2.78\end{array}$ & $\begin{array}{l}.46 \\
.49\end{array}$ & $\begin{array}{c}0 \\
-.04\end{array}$ & $\begin{array}{l}-.17 \\
-.08\end{array}$ & $\begin{array}{l}.80 \\
.67\end{array}$ & 1 & 9.2 & 1.3 & IIb \\
\hline G1.55 & 46 & $\begin{array}{l}3.85 \\
3.30\end{array}$ & $\begin{array}{l}.54 \\
.83\end{array}$ & $\begin{array}{l}+.10 \\
+.02\end{array}$ & $\begin{array}{l}+.27 \\
+.39\end{array}$ & $\begin{array}{r}.83 \\
1.24\end{array}$ & 5 & 5.4 & 2.3 & III \\
\hline $\mathrm{H} .01$ & 101 & $\begin{array}{l}2.88 \\
2.67\end{array}$ & $\begin{array}{l}.33 \\
.34\end{array}$ & $\begin{array}{c}-.27 \\
0\end{array}$ & $\begin{array}{l}-.36 \\
-.03\end{array}$ & $\begin{array}{l}.54 \\
.73\end{array}$ & 6 & & & V \\
\hline$H .10$ & 102 & 2.93 & .43 & -.19 & -.28 & .60 & 10 & & & $\mathrm{v}$ \\
\hline $\mathrm{H} \quad .20$ & 40 & 3.03 & .46 & -.04 & -.65 & 1.04 & 4 & & & $\mathrm{v}$ \\
\hline $\mathrm{H} \cdot 36$ & 103 & 3.07 & .40 & -.18 & -.45 & .92 & 14 & & & $\mathrm{v}$ \\
\hline $\mathrm{H} .60$ & 41 & 3.13 & .42 & -.02 & -.05 & .57 & 2 & & & $\mathrm{v}$ \\
\hline $\mathrm{H} .90$ & 42 & 2.96 & .38 &.$- u$ & -.32 & .50 & 2 & & & V \\
\hline 111.40 & 43 & 2.96 & .39 & -.18 & -.18 & .69 & 3 & & & V \\
\hline$P .02$ & 124 & $\begin{array}{l}2.70 \\
2.52\end{array}$ & $\begin{array}{l}.26 \\
.32\end{array}$ & $\begin{array}{l}+.04 \\
+.25\end{array}$ & $\begin{array}{l}+.12 \\
+.38\end{array}$ & $\begin{array}{l}.54 \\
.62\end{array}$ & $<1$ & 20.0 & 1.4 & I \\
\hline$P .20$ & 125 & $\begin{array}{l}2.78 \\
2.60\end{array}$ & $\begin{array}{l}.34 \\
.36\end{array}$ & $\begin{array}{c}-.06 \\
0\end{array}$ & -.03 & $\begin{array}{l}.62 \\
.65\end{array}$ & 1 & 2.5 & .7 & IIa \\
\hline$P .48$ & 33 & $\begin{array}{l}2.95 \\
2.74\end{array}$ & $\begin{array}{l}.47 \\
.52\end{array}$ & -.12 & $\begin{array}{l}-.25 \\
-.15\end{array}$ & $\begin{array}{l}.58 \\
.61\end{array}$ & 3 & 7.8 & 1.1 & IIa \\
\hline$P .52$ & 126 & $\begin{array}{l}2.67 \\
2.56\end{array}$ & $\begin{array}{l}.40 \\
.46\end{array}$ & $\begin{array}{c}+.07 \\
0\end{array}$ & $\begin{array}{l}+.15 \\
-.09\end{array}$ & $\begin{array}{l}.63 \\
.74\end{array}$ & 2 & 4.5 & 1.3 & IIa \\
\hline P1.80 & 83 & $\begin{array}{l}3.34 \\
3.13\end{array}$ & $\begin{array}{l}.36 \\
.36\end{array}$ & $0^{-.11}$ & $\begin{array}{l}-.22 \\
+.03\end{array}$ & $\begin{array}{l}.58 \\
.72\end{array}$ & 4 & 12.3 & .5 & I Ib \\
\hline P2.10 & 82 & $\begin{array}{l}3.31 \\
3.10\end{array}$ & $\begin{array}{l}.37 \\
.38\end{array}$ & -.19 & -.11 & $\begin{array}{l}.54 \\
.74\end{array}$ & 4 & 5.9 & 1.0 & IIb \\
\hline F3.10 & 81 & $\begin{array}{l}3.74 \\
3.41\end{array}$ & $\begin{array}{l}.66 \\
.64\end{array}$ & $\begin{array}{r}+.33 \\
+.33\end{array}$ & $\begin{array}{l}+1.20 \\
+1.50\end{array}$ & $\begin{array}{l}1.32 \\
1.70\end{array}$ & 8 & 7.3 & 1.0 & III \\
\hline
\end{tabular}


AFYgrDIL IB (cont.)

\begin{tabular}{|c|c|c|c|c|c|c|c|c|c|c|}
\hline \multirow{2}{*}{\multicolumn{2}{|c|}{$\begin{array}{l}\text { Sample } \\
\text { * star } \\
\text { tion No. }\end{array}$}} & \multicolumn{5}{|c|}{ Particle-91ze Distribution } & \multirow{2}{*}{$\begin{array}{c}\% \\
\text { N1ca- } \\
\text { ceous } \\
\text { (by } \\
\text { no.) }\end{array}$} & \multirow{2}{*}{$\begin{array}{c}\text { क } \\
\text { Heavy } \\
\text { Min- } \\
\text { oral } \\
\text { (by } \\
\text { wt.) }\end{array}$} & \multirow{2}{*}{$\begin{array}{c}\text { o } \\
\text { Car- } \\
\text { bon- } \\
\text { ate } \\
\text { (by } \\
\text { wt.) }\end{array}$} & \multirow{2}{*}{$\begin{array}{l}\text { t sed1- } \\
\text { ment } \\
\text { Type }\end{array}$} \\
\hline & & $\because \mathrm{d}_{\phi}$ & $\sigma \phi$ & $\alpha \phi$ & $\alpha 2 \phi$ & $\theta \&$ & & & & \\
\hline$R .15$ & 1 & $\begin{array}{l}2.99 \\
2.90\end{array}$ & $\begin{array}{l}.48 \\
.52\end{array}$ & $\begin{array}{c}-.06 \\
0\end{array}$ & $\begin{array}{l}0 \\
0\end{array}$ & $\begin{array}{l}.36 \\
.65\end{array}$ & 3 & 15.6 & .6 & I I a \\
\hline$\therefore .22$ & 2 & $\begin{array}{l}2.94 \\
2.86\end{array}$ & $\begin{array}{l}.47 \\
.46\end{array}$ & +.06 & +.13 & $\begin{array}{l}.70 \\
.65\end{array}$ & 4 & 14.8 & .9 & II a \\
\hline 只.39 & 3 & $\begin{array}{l}3.12 \\
3.02\end{array}$ & $\begin{array}{r}.43 \\
.44\end{array}$ & $\begin{array}{c}-.09 \\
0\end{array}$ & $\begin{array}{r}-.14 \\
+.02\end{array}$ & $\begin{array}{l}.51 \\
.66\end{array}$ & 7 & 13.9 & .3 & ITb \\
\hline$R .55$ & 4 & $\begin{array}{l}3.14 \\
3.07\end{array}$ & $\begin{array}{l}.42 \\
.43\end{array}$ & $\begin{array}{c}-.05 \\
0\end{array}$ & $\begin{array}{l}-.02 \\
-.02\end{array}$ & $\begin{array}{l}.50 \\
.67\end{array}$ & 4 & 13.4 & 1.6 & I Ib \\
\hline R.70 & 5 & $\begin{array}{l}3.12 \\
3.00\end{array}$ & $\begin{array}{l}.38 \\
.42\end{array}$ & $\begin{array}{c}.03 \\
0\end{array}$ & $\begin{array}{l}+.08 \\
+.10\end{array}$ & $\begin{array}{l}.66 \\
.71\end{array}$ & 19 & 12.4 & .8 & IIb \\
\hline $\mathrm{k} .86$ & 6 & $\begin{array}{l}3.32 \\
3.10\end{array}$ & .44 & $\begin{array}{l}-.18 \\
-.05\end{array}$ & $\begin{array}{r}+.32 \\
-.10\end{array}$ & $\begin{array}{l}.96 \\
.83\end{array}$ & 20 & 9.7 & .8 & $I T b$ \\
\hline Rl.17 & 7 & $\begin{array}{l}3.47 \\
3.33\end{array}$ & $\begin{array}{l}.53 \\
.54\end{array}$ & $\begin{array}{l}+.23 \\
+.17\end{array}$ & & & 15 & 8.4 & 2.0 & III \\
\hline$R 1.65$ & 8 & $\begin{array}{l}3.45 \\
3.30\end{array}$ & $\begin{array}{l}.58 \\
.54\end{array}$ & $\begin{array}{r}+.16 \\
+.19\end{array}$ & & & 18 & 10.1 & 1.8 & III \\
\hline 3.05 & 134 & $\begin{array}{c}2.58 \\
2.42\end{array}$ & $\begin{array}{l}.26 \\
.30\end{array}$ & $\begin{array}{l}0 \\
+.10\end{array}$ & $\begin{array}{l}-.04 \\
+.30\end{array}$ & $\begin{array}{l}.70 \\
.80\end{array}$ & $<1$ & & & I \\
\hline 3.10 & 135 & 2.55 & .32 & -.03 & -.03 & .63 & 2 & & & IIa \\
\hline 3.56 & 9 & 2.37 & .54 & -.11 & -.17 & $1 . \infty$ & 1 & & & II \\
\hline S. .85 & 10 & 3.38 & .37 & -.05 & -.16 & .68 & 18 & & & I Ia \\
\hline 31.40 & 11 & 3.26 & .53 & +.02 & +2.00 & 2.57 & 18 & & & VII \\
\hline 31.80 & 12 & 3.45 & .39 & -.10 & +.92 & 1.17 & 5 & & & VII \\
\hline U & 132 & $\begin{array}{l}2.35 \\
2.24\end{array}$ & $\begin{array}{l}.22 \\
.32\end{array}$ & $\begin{array}{l}+.04 \\
+.12\end{array}$ & $\begin{array}{l}+.27 \\
+.31\end{array}$ & $\begin{array}{l}.68 \\
.81\end{array}$ & $<1$ & & & I \\
\hline $\mathrm{U} .10$ & 133 & 2.45 & .37 & 0 & +.03 & .70 & 2 & & & IIa \\
\hline
\end{tabular}


ATPTIDIY IB (cont.)

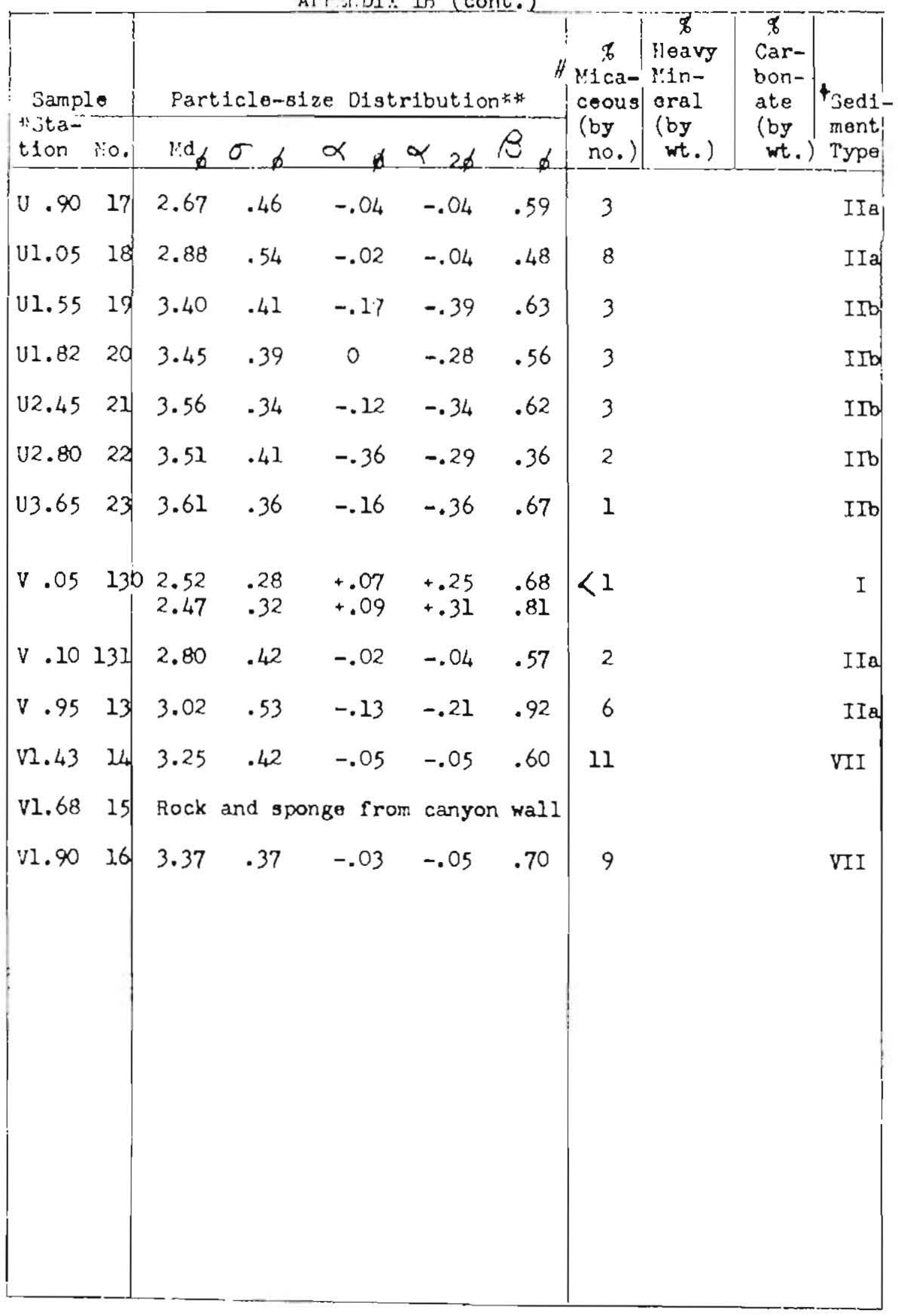


APPLNDIX IC

17 - 18 November 1949, Beach and Botton Sediments

\begin{tabular}{|c|c|c|c|c|c|c|c|c|c|c|}
\hline \multirow{2}{*}{\multicolumn{2}{|c|}{$\begin{array}{l}\text { Sample } \\
\text { *Sta: } \\
\text { tion No. }\end{array}$}} & \multicolumn{5}{|c|}{ Particle-size Distribution } & \multirow{2}{*}{$\begin{array}{l}x \\
\text { hica- } \\
\text { coous } \\
\text { (by } \\
\text { no.) }\end{array}$} & \multirow{2}{*}{$\begin{array}{l}\text { g } \\
\text { Heavy } \\
\text { Min- } \\
\text { eral } \\
\text { (by } \\
\text { wt.) }\end{array}$} & \multirow{2}{*}{$\begin{array}{l}\text { d } \\
\text { Car- } \\
\text { bon- } \\
\text { ato } \\
\text { (by } \\
\text { wt.) }\end{array}$} & \multirow{2}{*}{$\mid \begin{array}{l}t_{\text {Sed }} \\
\text { ment } \\
\text { Tyme }\end{array}$} \\
\hline & & ${ }^{M d_{\phi}}$ & $\sigma \phi$ & $\propto \phi$ & $\propto 2 \phi$ & $S_{6}$ & & & & \\
\hline A. .10 & & Most & rock & & & & & & & \\
\hline A. .48 & 3 & 2.75 & .40 & 0 & -.12 & .72 & 3 & & & IIa \\
\hline A1. $\infty$ & 88 & 3.02 & .38 & -.06 & -.08 & .65 & 3 & & & IIa \\
\hline A1.18 & 87 & 3.20 & .37 & -.15 & -.20 & .67 & 5 & & & ITb \\
\hline A1. 40 & 86 & 3.28 & .37 & -.09 & -.23 &, 63 & 5 & & & $I I b$ \\
\hline A. 1.65 & 85 & 3.34 & .38 & -.06 & -.18 & .61 & 1 & & & $I \mathrm{Ib}^{\prime}$ \\
\hline A2.05 & 84 & 3.25 & .43 & -.10 & -.12 & .54 & 8 & & & $I \mathrm{Ib}$ \\
\hline B .07 & 118 & 2.82 & .27 & -.04 & 0 & .65 & 2 & 16.3 & & $I$ \\
\hline & & 2.59 & .33 & +.21 & +.39 & .70 & & & & \\
\hline 8.13 & 119 & 2.88 & .32 & +.03 & +.06 & .50 & 7 & & & $I I a$ \\
\hline B . .51 & 4 & 2.81 & .45 & -.07 & -.05 & .46 & 3 & & & IIa \\
\hline 8.80 & 77 & 2.63 & .37 & -.09 &.- .12 & .72 & 4 & & & IIa \\
\hline $81 . \infty$ & 78 & 3.04 & .39 & 0 & 0 & .67 & 5 & & & IIa \\
\hline 81.40 & 79 & 3.37 & .35 & -.21 & -.39 & .68 & 3 & & & $I m b$ \\
\hline $\mathrm{B} 1.95$ & 80 & 3.33 & .36 & -.11 & -.28 & .72 & 3 & & & Inb \\
\hline$B 2.25$ & 81 & 3.37 & .38 &.$- u_{4}$ & -.24 & .52 & 3 & & & IIb \\
\hline 82.90 & 82 & 3.40 & .37 & -.12 & -.33 & .72 & 6 & & & $\mathrm{IID}$ \\
\hline B3.60 & 83 & 3.70 & .41 & +.09 & +.37 & .78 & 5 & & & ryis \\
\hline C. .05 & 115 & 2.47 & .24 & -.06 & -.10 & .73 & $<1$ & & & I \\
\hline C. .12 & 116 & $\begin{array}{l}2.47 \\
2.34\end{array}$ & $\begin{array}{r}.24 \\
.30 \\
\end{array}$ & $\begin{array}{l}+.04 \\
+.07\end{array}$ & $\begin{array}{r}+.08 \\
+.30 \\
\end{array}$ & $\begin{array}{l}.88 \\
.83\end{array}$ & $<1$ & 7.7 & & $I$ \\
\hline
\end{tabular}




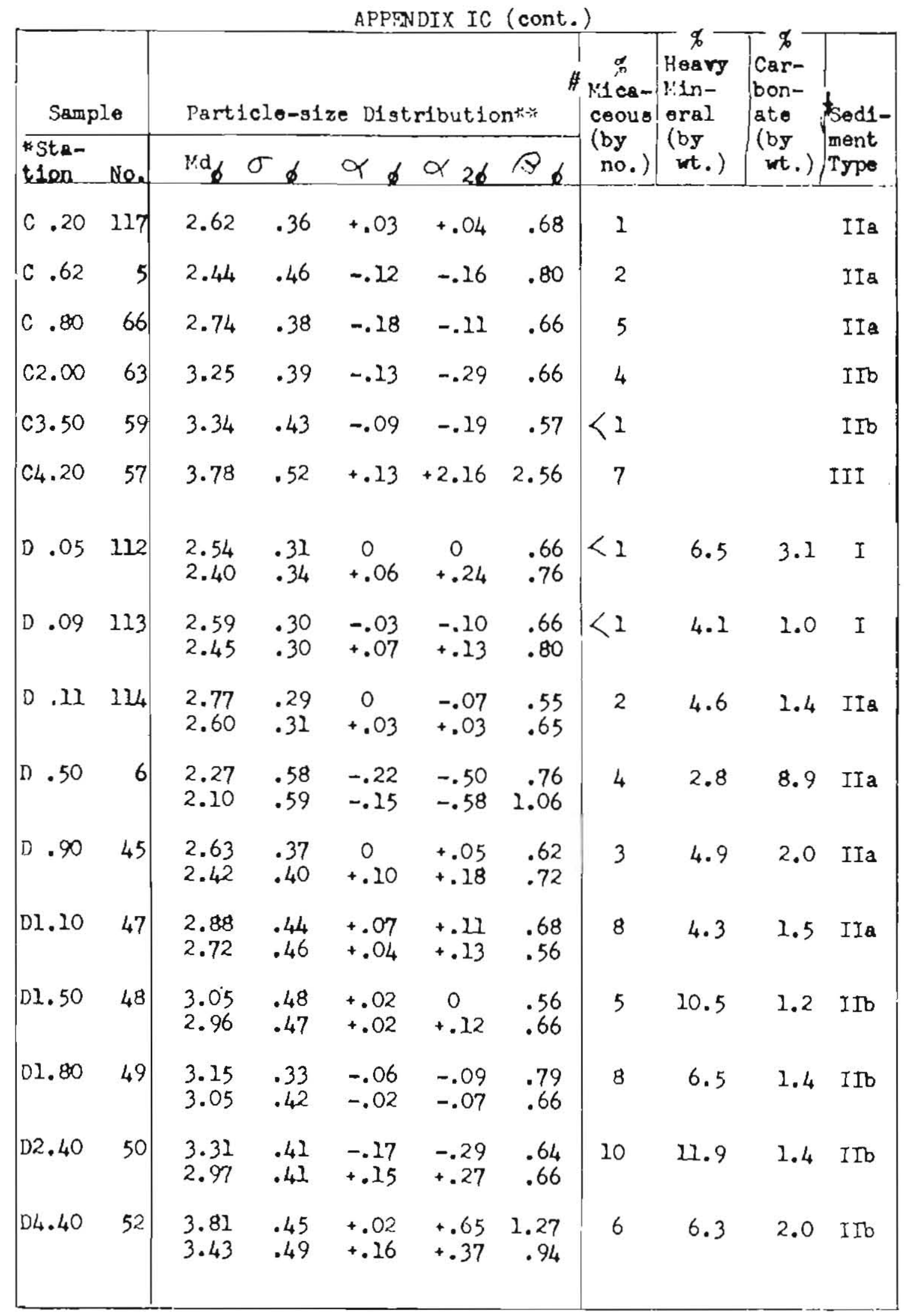


APPENDIX IC (cont.)

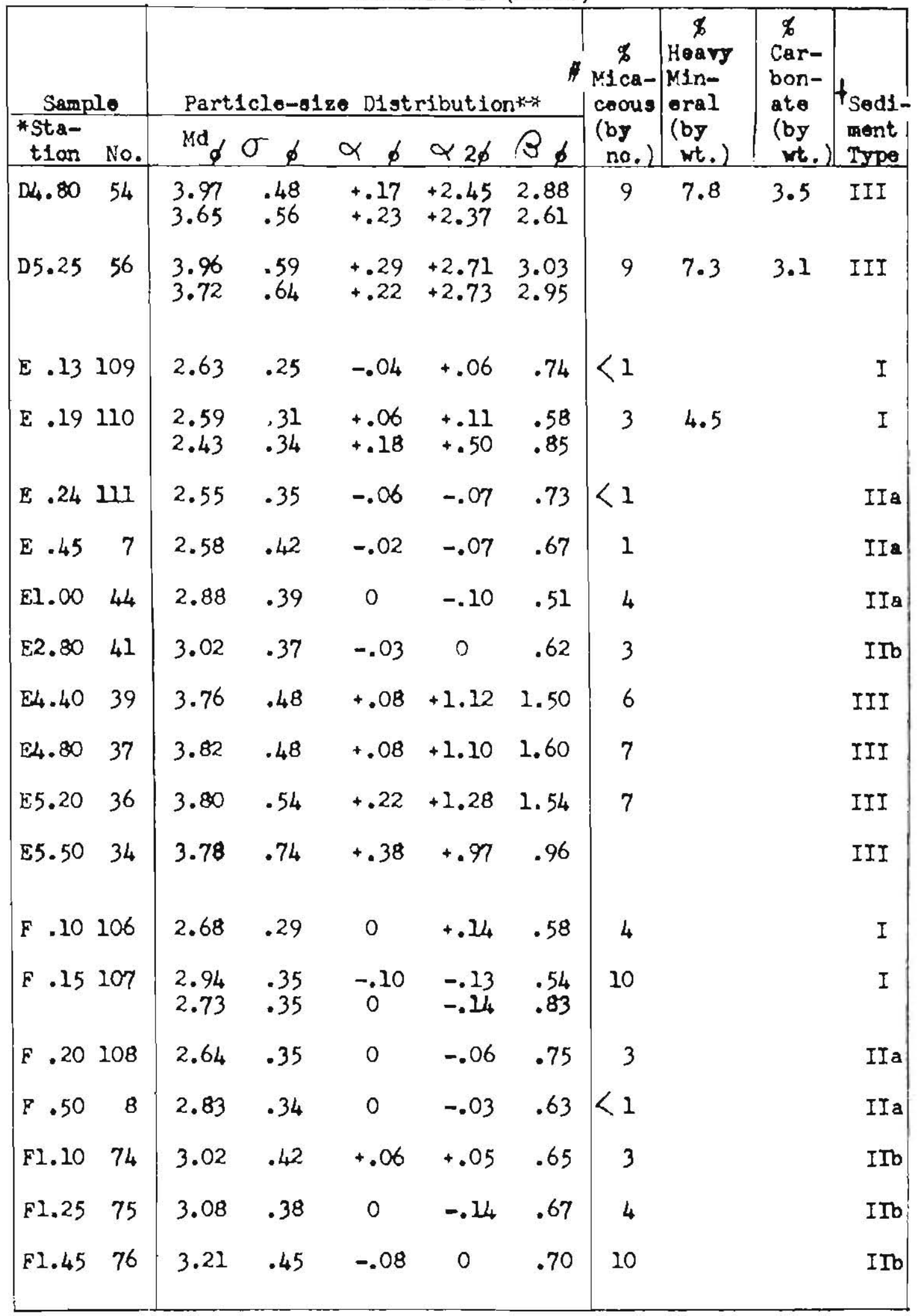


APPENDIX IC (cont.)

\begin{tabular}{|c|c|c|c|c|c|c|c|c|c|c|}
\hline \multirow{2}{*}{\multicolumn{2}{|c|}{$\begin{array}{l}\text { Sample } \\
\text { KSta- } \\
\text { t1on No. }\end{array}$}} & \multicolumn{5}{|c|}{ Particlonsize Distribution } & \multirow{2}{*}{ 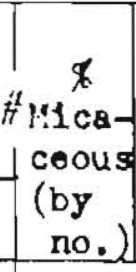 } & \multirow{2}{*}{$\begin{array}{l}q \\
\text { Heavy } \\
\text { Niln- } \\
\text { eral } \\
\text { (by } \\
\text { wt.) }\end{array}$} & \multirow{2}{*}{$\begin{array}{c}\% \\
\text { Car- } \\
\text { bon- } \\
\text { ate } \\
\text { (by } \\
\text { wt.) }\end{array}$} & \multirow{2}{*}{$\begin{array}{r}\text { Sedi } \\
\text { ment } \\
\text { Type } \\
\end{array}$} \\
\hline & & $M_{6}$ & $\sigma \phi$ & $\alpha \phi$ & $\alpha 2 \phi$ & $\beta_{\phi}$ & & & & \\
\hline G. .06 & 103 & 2.58 & .32 & -.09 & 0 & .66 & $<1$ & & & $I$ \\
\hline G. .12 & 104 & $\begin{array}{l}3.00 \\
2.80\end{array}$ & $\begin{array}{l}.38 \\
.34\end{array}$ & -.21 & $\begin{array}{l}-.37 \\
-.12\end{array}$ & $\begin{array}{l}.60 \\
.88\end{array}$ & 6 & & & I \\
\hline$G .21$ & 105 & 2.80 & .44 & -.07 & -.03 & .69 & 5 & & & IIe \\
\hline$G .45$ & 9 & 2.90 & .37 & -.03 & +.08 & .89 & 2 & & & IIa \\
\hline$G .90$ & 73 & 2.95 & .42 & -.02 & -.13 & .66 & 3 & & & II \\
\hline G1.15 & 72 & 3.15 & .45 & -.10 & -.26 & .78 & 15 & & & IID \\
\hline G1. 32 & 71 & $\begin{array}{r}6.95 \\
\text { (Hard }\end{array}$ & $\begin{array}{c}4.24 \\
\text { packed }\end{array}$ & $\begin{array}{l}+.38 \\
\text { wth wo }\end{array}$ & rm bort & ngs) & & & & \\
\hline G1. 55 & 70 & 3.60 & 2.65 & +.56 & & & 3 & & & III \\
\hline $\mathrm{H} .01$ & 100 & $\begin{array}{l}2.49 \\
2.77\end{array}$ & $\begin{array}{l}.34 \\
.29\end{array}$ & +.21 & $i^{53}$ & $\begin{array}{l}.68 \\
.86\end{array}$ & 4 & & & $\mathrm{v}$ \\
\hline H .07 & 101 & 2.64 & .57 & -.33 & -.69 & .78 & 4 & & & V \\
\hline $\mathrm{H} \cdot 32$ & 10 & 2.76 & .56 & -.22 & -.63 & .76 & 3 & & & $\nabla$ \\
\hline 111.63 & 29 & 2.93 & .44 & -.12 & -.56 & .90 & 4 & & & V \\
\hline $\mathrm{H} .90$ & 28 & 2.90 & .40 & -.07 & -.27 & 1.05 & 2 & & & $\nabla$ \\
\hline $\mathrm{Hl} .15$ & 27 & 2.88 & .54 & -.10 & -.52 & .97 & 2 & & & $\nabla$ \\
\hline$H 1.40$ & 26 & 2.87 & .70 & -.16 & -.41 & .76 & 4 & & & $\nabla$ \\
\hline $\mathrm{H} 1.70$ & 25 & 2.93 & 1.03 & -.30 & -.15 & 1.11 & 3 & & & V \\
\hline H2. 20 & 24 & See & $\mathrm{LC}-7, \mathrm{~A}$ & p. II & & & & & & \\
\hline $\mathrm{H} 2.75$ & 23 & See & $L C-8, A$ & p. II & & & & & & \\
\hline I . .50 & 32 & .824 & .46 & -.26 & -1.37 & 1.20 & $<1$ & & & $\nabla$ \\
\hline 11.00 & 11 & 3.15 & .45 & -.22 & -1.15 & 1.41 & 1 & & & 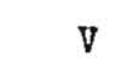 \\
\hline
\end{tabular}


AFPINDIX IC (cont.)

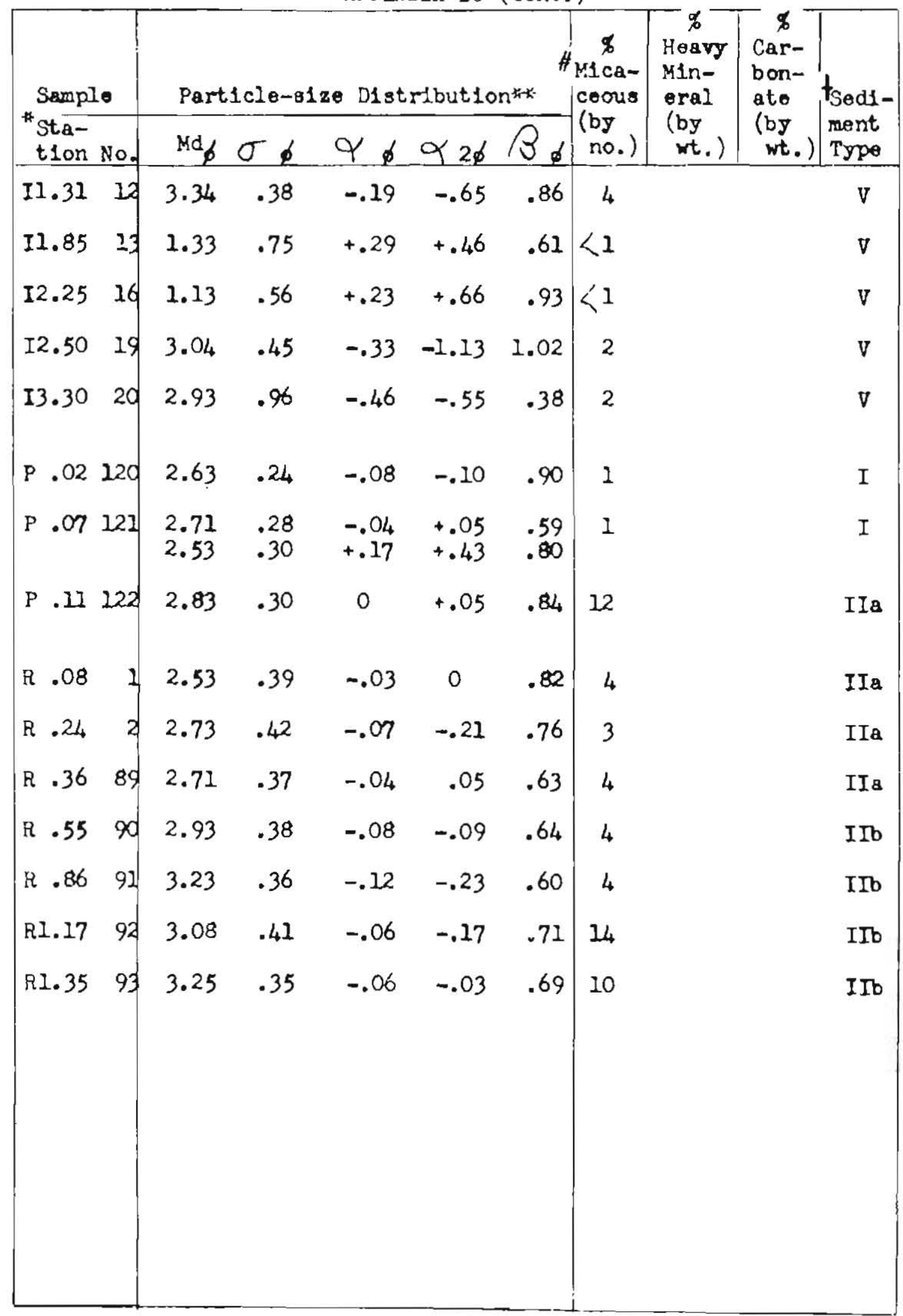


APPEN:DIX ID

15 - 16 March 1950, Beach and Bottom Sediments

\begin{tabular}{|c|c|c|c|c|c|c|c|c|c|c|}
\hline Sampl & & Part & $\operatorname{cl} \theta-812$ & e 01 str & 1but1on & & $\begin{array}{l}\% \\
\text { M1ca- } \\
\text { ceous }\end{array}$ & $\begin{array}{l}\stackrel{\sigma}{0} \\
\text { Heavy } \\
\text { lin- } \\
\text { oral }\end{array}$ & $\begin{array}{l}\text { of } \\
\text { Car- } \\
\text { bon- } \\
\text { ate }\end{array}$ & $t_{\text {Seds }}$ \\
\hline $\begin{array}{l}\text { Sta- } \\
\text { t1on }\end{array}$ & No. & $1 \alpha_{\phi}$ & $\sigma_{\phi}$ & $\alpha_{\phi}$ & $\alpha_{2 \phi}$ & $\theta_{\phi}$ & $\begin{array}{l}\text { (by } \\
\text { no.) }\end{array}$ & $\begin{array}{l}\text { (by } \\
\text { wt. })\end{array}$ & $\begin{array}{c}\text { (by } \\
w t .)\end{array}$ & $\begin{array}{l}\text { ment } \\
\text { Type }\end{array}$ \\
\hline A. .01 & & Nostl & rock, & no sand & & & & & & \\
\hline A. .82 & 82 & 2.63 & .37 & -.03 & -.08 & .84 & 1 & 11.9 & & IIa \\
\hline $11 . \infty$ & 81 & 2.85 & .43 & +.05 & -.18 & .63 & 2 & 17.1 & & IIa \\
\hline 11.20 & 80 & 2.94 & .41 & -.02 & -.02 & .66 & 1 & 19.3 & & ITo \\
\hline $\mathrm{Al} .40$ & 79 & 3.08 & .40 & -.16 & -.13 & .59 & 3 & 16.1 & & ITo \\
\hline 11.65 & 78 & 3.04 & .40 & -.06 & -.07 & .70 & 3 & 12.3 & & ITo \\
\hline A2.05 & 77 & 3.23 & .42 & -.08 & -.19 & .64 & 2 & 6.6 & & IIo \\
\hline B. .04 & 18 & 2.48 & .24 & -.04 & -.06 & .60 & 1 & 18.4 & & I \\
\hline B. .12 & 17 & $\begin{array}{l}2.68 \\
2.48\end{array}$ & $\begin{array}{r}.26 \\
.30\end{array}$ & $\begin{array}{l}0 \\
+.17\end{array}$ & $\begin{array}{c}0 \\
+.47\end{array}$ & $\begin{array}{l}.66 \\
.73\end{array}$ & $<1$ & 36.2 & & $I$ \\
\hline B. .26 & 16 & 2.47 & .34 & -.06 & -.10 & .72 & $<1$ & 5.0 & & IIa \\
\hline 81.00 & 76 & 2.52 & .41 & -.14 & -.49 & .90 & 1 & 8.4 & & IIa \\
\hline$B 1.12$ & 75 & 2.78 & .41 & +.08 & +.19 & .54 & 2 & 10.4 & & IIb \\
\hline B1.22 & 74 & 3.00 & .40 & -.05 & -.01 & .59 & 3 & 14.5 & & Irb \\
\hline$B 2.40$ & 73 & 3.14 & .38 & -.05 & -.04 & .59 & $<1$ & 13.7 & & Irb \\
\hline 81.95 & 72 & 3.32 & .37 & -.05 & -.26 & .69 & 5 & 9.7 & & ITb \\
\hline B2. 25 & 72 & 3.37 & .36 & -.19 & -.26 & .54 & 6 & 10.8 & & ITo \\
\hline 83.00 & 69 & 3.38 & .45 & -.07 & +.04 & .73 & 2 & 14.3 & & Itb \\
\hline B3.60 & 70 & 3.68 & .42 & +.07 & +.17 & .68 & 5 & 9.1 & & ITo \\
\hline
\end{tabular}

ID-1 


\begin{tabular}{|c|c|c|c|c|c|c|c|c|c|c|}
\hline \multirow{2}{*}{\multicolumn{2}{|c|}{$\begin{array}{l}\text { Samplo } \\
\text { Sta- } \\
\text { tion No. No. }\end{array}$}} & \multicolumn{5}{|c|}{ Particle-size Distribution } & \multirow{2}{*}{$\begin{array}{c}\% \\
M 1 \mathrm{ca}- \\
\text { coous } \\
\text { (by } \\
\text { no.) }\end{array}$} & \multirow{2}{*}{$\begin{array}{c}\text { o } \\
\text { Heavy } \\
\text { pin- } \\
\text { eral } \\
\text { (by } \\
\text { wt.) }\end{array}$} & \multirow{2}{*}{$\begin{array}{l}\phi \\
\text { Car- } \\
\text { bon- } \\
\text { ate } \\
\text { (by } \\
\text { wt.) }\end{array}$} & \multirow{2}{*}{$\begin{array}{l}\text { Seds- } \\
\text { ment } \\
\text { Type }\end{array}$} \\
\hline & & $\because 6$ & $\sigma_{6}$ & $x d$ & $\alpha_{26}$ & & & & & \\
\hline C. .04 & 21 & 2.56 & .26 & -.06 & -.02 & .64 & 2 & 27.1 & & I \\
\hline C. .08 & 20 & $\begin{array}{l}2.49 \\
2.42\end{array}$ & $\begin{array}{l}.24 \\
.28\end{array}$ & $\begin{array}{c}0 \\
+.14\end{array}$ & $\begin{array}{l}+.02 \\
+.43\end{array}$ & $\begin{array}{l}.60 \\
.86\end{array}$ & 1 & 17.3 & & I \\
\hline C. .21 & 19 & 2.53 & .31 & -.08 & -.08 & .70 & 1 & 6.3 & & IIa \\
\hline C. .80 & 68 & 2.74 & .46 & 0 & -.12 & .68 & 1 & 14.0 & & IIa \\
\hline Cl.10 & 67 & 2.60 & .39 & +.05 & -.01 & .86 & $<1$ & 9.4 & & II \\
\hline Cl. 40 & 66 & 3.00 & .39 & -.04 & -.01 & .71 & 1 & 10.0 & & IIb \\
\hline C1. 46 & 65 & 3.04 & .37 & -.08 & -.16 & .70 & 9 & 10.1 & & ITb \\
\hline 02.00 & 64 & 3.23 & .40 & -.12 & -.14 & .56 & 4 & 9.7 & & I Ib \\
\hline $\mathrm{C} 2.95$ & 63 & 3.24 & .45 & 0 & +.15 & .74 & 2 & 16.7 & & ITb \\
\hline C3.50 & 62 & 3.30 & .45 & 0 & +.14 & .70 & 2 & 15.1 & & ITb \\
\hline $\mathrm{CL}_{4} .45$ & 61 & 3.95 & .52 & +.08 & +1.37 & 1.84 & 10 & 7.8 & & III \\
\hline D. .02 & 11 & $\begin{array}{l}2.41 \\
2.32\end{array}$ & $\begin{array}{l}.25 \\
.30\end{array}$ & $\begin{array}{r}-.04 \\
+.13\end{array}$ & $\begin{array}{r}-.12 \\
+.43\end{array}$ & $\begin{array}{l}.72 \\
.83\end{array}$ & $<1$ & 19.1 & 4.6 & I \\
\hline D. .10 & 10 & $\begin{array}{l}2.50 \\
2.34\end{array}$ & $\begin{array}{l}.24 \\
.32\end{array}$ & $\begin{array}{c}0 \\
+.19\end{array}$ & $\begin{array}{r}-.12 \\
+.25\end{array}$ & $\begin{array}{l}.62 \\
.75\end{array}$ & $<1$ & 13.0 & 2.7 & I \\
\hline D .22 & 9 & $\begin{array}{l}2.28 \\
2.14\end{array}$ & $\begin{array}{l}.35 \\
.39\end{array}$ & $\begin{array}{l}+.06 \\
+.05\end{array}$ & $\begin{array}{l}0 \\
0\end{array}$ & $\begin{array}{l}.71 \\
.79\end{array}$ & $<1$ & 2.7 & 3.0 & II a \\
\hline DI.25 & 60 & $\begin{array}{l}2.82 \\
2.66\end{array}$ & $\begin{array}{l}.40 \\
.41\end{array}$ & $\begin{array}{c}0 \\
+.07\end{array}$ & $\begin{array}{c}0 \\
+.10\end{array}$ & $\begin{array}{l}.70 \\
.70\end{array}$ & 6 & 8.7 & 2.2 & II \\
\hline D1. 50 & 59 & $\begin{array}{l}2.96 \\
2.80\end{array}$ & $\begin{array}{l}.46 \\
.43\end{array}$ & $\begin{array}{l}0 \\
0\end{array}$ & $\begin{array}{c}+.22 \\
0\end{array}$ & $\begin{array}{l}.76 \\
.67\end{array}$ & 10 & 7.5 & 2.1 & IIb \\
\hline D1.80 & 58 & $\begin{array}{l}3.10 \\
3.02\end{array}$ & $\begin{array}{l}.49 \\
.48\end{array}$ & +.02 & $\begin{array}{l}+.18 \\
-.02\end{array}$ & $\begin{array}{l}.83 \\
.69\end{array}$ & 9 & 8.0 & 2.0 & IIb \\
\hline D2. 40 & 57 & $\begin{array}{l}3.28 \\
3.10\end{array}$ & $\begin{array}{l}.40 \\
.40\end{array}$ & $\begin{array}{l}-.10 \\
-.08\end{array}$ & $\begin{array}{l}-.12 \\
-.15\end{array}$ & $\begin{array}{l}.60 \\
.70\end{array}$ & 11 & 11.7 & 1.1 & ITb \\
\hline
\end{tabular}




\begin{tabular}{|c|c|c|c|c|c|c|c|c|c|c|}
\hline \multicolumn{2}{|c|}{ Sample } & \multicolumn{2}{|c|}{ Part1010-01z } & \multicolumn{3}{|c|}{ - D1stribution* } & $\begin{array}{c}\% \\
\text { KI ca- } \\
\text { coous }\end{array}$ & \multirow{2}{*}{$\begin{array}{c}6 \\
\text { Heavy } \\
\text { Min- } \\
\text { oral } \\
\text { (by } \\
\text { wt.) }\end{array}$} & \multirow{2}{*}{$\begin{array}{c}\% \\
\text { car- } \\
\text { bon- } \\
\text { ate } \\
\text { (by } \\
\text { ut.) }\end{array}$} & \multirow{2}{*}{$\begin{array}{l}\text { tseds- } \\
\text { ment } \\
\text { Tyme }\end{array}$} \\
\hline $\begin{array}{l}\text { *Sta- } \\
\text { t1on }\end{array}$ & No. & $\mathrm{Md}_{6}$ & $\sigma 6$ & $\alpha \phi$ & $\alpha 26$ & 8 & $\begin{array}{c}\text { (by } \\
\text { no.) }\end{array}$ & & & \\
\hline $\mathrm{D} 2.85$ & 56 & $\begin{array}{l}3.22 \\
2.92\end{array}$ & $\begin{array}{r}.38 \\
.38\end{array}$ & $\begin{array}{l}0 \\
0\end{array}$ & $\begin{array}{l}-.08 \\
-.16\end{array}$ & $\begin{array}{l}.68 \\
.84\end{array}$ & 1 & 15.1 & 1.5 & ITb \\
\hline D3.75 & 55 & $\begin{array}{l}3.30 \\
3.10\end{array}$ & $\begin{array}{r}.45 \\
.38\end{array}$ & $\begin{array}{l}+.02 \\
-.03\end{array}$ & $\begin{array}{l}+.09 \\
-.03\end{array}$ & $\begin{array}{l}.69 \\
.71\end{array}$ & 2 & 15.0 & 1.0 & IIb \\
\hline $104 . \infty$ & 54 & $\begin{array}{l}3.56 \\
3.20\end{array}$ & $\begin{array}{l}.40 \\
.39\end{array}$ & $\begin{array}{r}+.02 \\
+.13\end{array}$ & $\begin{array}{r}+.02 \\
+.74\end{array}$ & $\begin{array}{r}.72 \\
1.18\end{array}$ & 6 & 7.5 & 1.4 & ITb \\
\hline 104.40 & 53 & $\begin{array}{l}3.88 \\
3.48\end{array}$ & $\begin{array}{l}.46 \\
.50\end{array}$ & $\begin{array}{r}+.09 \\
+.18\end{array}$ & $\begin{array}{r}+1.59 \\
+1.80\end{array}$ & $\begin{array}{l}2.13 \\
2.24\end{array}$ & 7 & 7.5 & 2.7 & IIb \\
\hline D5.25 & 52 & $\begin{array}{l}3.88 \\
3.57\end{array}$ & $\begin{array}{r}.56 \\
.61\end{array}$ & $\begin{array}{r}+.18 \\
+.33\end{array}$ & $\begin{array}{l}+2.08 \\
+2.28\end{array}$ & $\begin{array}{l}2.48 \\
2.34\end{array}$ & 10 & 8.8 & 3.0 & III \\
\hline E. .07 & 8 & 2.58 & .23 & -.06 & -.04 & .79 & 1 & 38.2 & & I \\
\hline$E .14$ & 7 & $\begin{array}{l}2.60 \\
2.44\end{array}$ & $\begin{array}{l}.24 \\
.27\end{array}$ & $\begin{array}{r}-.06 \\
+.19\end{array}$ & $\begin{array}{l}-.06 \\
+.44\end{array}$ & $\begin{array}{l}.73 \\
.85\end{array}$ & $<1$ & 11.2 & & $I$ \\
\hline El. 00 & 51 & 2.63 & .37 & 0 & -.01 & .85 & $<1$ & 10.8 & & II \\
\hline EI.25 & 50 & 2.67 & .42 & +.18 & +.20 & .52 & 1 & 11.6 & & IIa \\
\hline E1.45 & 49 & 2.85 & .44 & +.11 & +.40 & .83 & 1 & 12.0 & & ITb \\
\hline E1.65 & 48 & 2.93 & .41 & -.05 & -.12 & .47 & 2 & 9.8 & & ITb \\
\hline$E 2 . \infty$ & 47 & 3.17 & .50 & -.10 & -.17 & .67 & 35 & 8.9 & & IIO \\
\hline$E 2.80$ & 46 & $3 . \infty$ & .36 & +.01 & +.12 & .57 & 4 & 11.3 & & IIb \\
\hline E3.40 & 45 & $\begin{array}{l}3.08 \\
2.96\end{array}$ & $\begin{array}{r}.41 \\
.42\end{array}$ & +.02 & +.02 & $\begin{array}{l}.66 \\
.65\end{array}$ & 3 & 10.8 & 0.9 & IIb \\
\hline$F 4.38$ & 44 & $\begin{array}{l}3.57 \\
3.25\end{array}$ & $\begin{array}{l}.52 \\
.40\end{array}$ & $\begin{array}{l}+.04 \\
+.05\end{array}$ & $\begin{array}{r}+.73 \\
+.08\end{array}$ & $\begin{array}{r}1.25 \\
.90\end{array}$ & 8 & 8.3 & 2.0 & III \\
\hline$E 5.50$ & 43 & 3.80 & 1.07 & +.42 & +.98 & .94 & 8 & 5.7 & & III \\
\hline$P .07$ & 4 & 2.66 & .27 & -.04 & -.04 & .56 & 2 & 17.7 & & I \\
\hline$F .18$ & 3 & $\begin{array}{r}2.67 \\
2.48 \\
\end{array}$ & $\begin{array}{l}.28 \\
.30 \\
\end{array}$ & $\begin{array}{c}0 \\
+.20 \\
\end{array}$ & $\begin{array}{r}-.05 \\
+.40 \\
\end{array}$ & $\begin{array}{l}.70 \\
.73 \\
\end{array}$ & 1 & 7.3 & & $I$ \\
\hline
\end{tabular}


APPENDIX ID (cont.)

\begin{tabular}{|c|c|c|c|c|c|c|c|c|c|}
\hline \multirow{2}{*}{$\begin{array}{l}\text { Sample } \\
\text { tion No }\end{array}$} & \multicolumn{2}{|c|}{ Part1clo-81xo } & \multicolumn{3}{|c|}{ D1etributiontat } & \multirow{2}{*}[\begin{array}{c}{\phi}\\
{M1cs}\\
{\text{coous}}\\
{\text{(by}}\\
{\text{no.})}\end{array}]{} & \multirow{2}{*}{$\begin{array}{c} \\
\text { Heavy } \\
\text { Min- } \\
\text { oral } \\
\text { (by } \\
\text { wt.) }\end{array}$} & \multirow{2}{*}{$\begin{array}{l}-g \\
\text { Car- } \\
\text { bon- } \\
\text { ate } \\
\text { (by } \\
\text { wt.) }\end{array}$} & \multirow{2}{*}{$\begin{array}{l}t_{\text {Sodi- }}- \\
\text { ment } \\
\text { Type }\end{array}$} \\
\hline & $\mathrm{Md}_{6}$ & ब & $\alpha 6$ & $x_{2}$ & 3 & & & & \\
\hline$F .80 \quad 42$ & 2.53 & .42 & +.06 &.$+ u_{4}$ & .67 & 1 & 8.7 & & II \\
\hline$F .9541$ & 2.55 & .39 & +.06 & +.11 & .68 & 1 & 6.1 & & $\mathrm{IIg}$ \\
\hline F1.15 40 & 2.74 & .40 & -.02 & +.02 & .57 & 3 & 11.8 & & IIb \\
\hline F1.25 39 & 2.83 & .36 & 0 & 0 & .66 & & & & ITb \\
\hline$F 1.6538$ & $\begin{array}{l}3.27 \\
3.14\end{array}$ & $\begin{array}{l}.50 \\
.53\end{array}$ & $\begin{array}{l}+.06 \\
+.08\end{array}$ & $\begin{array}{l}+.32 \\
+.42\end{array}$ & $\begin{array}{r}1.02 \\
.96\end{array}$ & & 7.8 & & III \\
\hline c. .06 2 & $\begin{array}{l}2.54 \\
2.42\end{array}$ & $\begin{array}{l}.28 \\
.28\end{array}$ & $\begin{array}{l}+.02 \\
+.07\end{array}$ & $\begin{array}{l}+.10 \\
+.29\end{array}$ & $\begin{array}{l}.75 \\
.86\end{array}$ & $<1$ & 9.2 & & I \\
\hline G .151 & 2.56 & .33 & -.03 & -.04 & .74 & $<1$ & 7.7 & & IIa \\
\hline G .70 36 & 2.67 & .32 & -.06 & 0 & .76 & $<1$ & 15.5 & & II 8 \\
\hline G .90 37 & 2.77 & .33 & +.10 & +.01 & .69 & 2 & 16.8 & & IIa \\
\hline 11 .006 & 2.01 & .84 & -.14 & -.43 & .62 & $<1$ & & & v \\
\hline$H .10 \quad 5$ & $\begin{array}{l}2.56 \\
2.48\end{array}$ & .61 & $\begin{array}{l}-.29 \\
-.43\end{array}$ & $\begin{array}{l}-.87 \\
-.63\end{array}$ & .97 & $<1$ & 3.0 & & v \\
\hline H. .3835 & 2.63 & .67 & -.36 & -.67 & .70 & 1 & 10.0 & & v \\
\hline $\mathrm{H} .6034$ & 2.98 & .39 & -.16 & -.60 & .96 & 3 & 13.7 & & $\nabla$ \\
\hline H.9033 & 2.83 & .39 & -.10 & -.36 & .92 & 1 & 12.2 & & V \\
\hline $\mathrm{H} 1.4032$ & $\begin{array}{l}2.98 \\
2.79\end{array}$ & $\begin{array}{l}.45 \\
.46\end{array}$ & $\begin{array}{l}-.07 \\
-.02\end{array}$ & $\begin{array}{l}-.22 \\
-.78\end{array}$ & $\begin{array}{r}.96 \\
1.67\end{array}$ & 4 & 8.0 & 2.3 & $\nabla$ \\
\hline I1.00 28 & $\begin{array}{l}3.05 \\
2.92\end{array}$ & $\begin{array}{l}.45 \\
.45\end{array}$ & $\begin{array}{l}-.18 \\
-.04\end{array}$ & $\begin{array}{l}-.76 \\
-.80\end{array}$ & $\begin{array}{l}1.11 \\
1.31\end{array}$ & 2 & 13.6 & 2.2 & V \\
\hline I1.35 29 & 3.23 & .41 & -.27 & -.74 & 1.01 & 1 & & & $v$ \\
\hline Il. 8030 & 2.85 & .77 & -.42 & -.65 & .53 & 1 & & & v \\
\hline 12.4031 & 1.28 & 1.07 & +.46 & +.50 & .34 & $<1$ & (bimon & (a1) & $\nabla$ \\
\hline
\end{tabular}




\begin{tabular}{|c|c|c|c|c|c|c|c|c|c|c|}
\hline $\begin{array}{l}\text { Samp } \\
\text { Sta- } \\
\text { tion }\end{array}$ & No & Part 1 & $\frac{1 c l 0-s 1}{06}$ & $\frac{20 D}{\alpha \phi}$ & $\frac{\text { ribut1o }}{\times 2 \phi}$ & $\beta \phi$ & 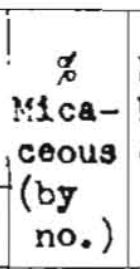 & \begin{tabular}{l}
\multicolumn{1}{c}{ क } \\
lleavy \\
M1n- \\
oral \\
(by \\
wt.)
\end{tabular} & $\begin{array}{c}\text { o } \\
\text { Car- } \\
\text { bon- } \\
\text { ato } \\
\text { (by } \\
\text { wt.) }\end{array}$ & $\begin{array}{l}\text { Sedi } \\
\text { ment } \\
\text { Type }\end{array}$ \\
\hline$P .05$ & 14 & $\begin{array}{l}2.49 \\
2.39\end{array}$ & $\begin{array}{l}.22 \\
.30\end{array}$ & $\begin{array}{r}+.02 \\
+.13\end{array}$ & $\begin{array}{l}+.04 \\
+.37\end{array}$ & $\begin{array}{l}.73 \\
.80\end{array}$ & $<1$ & 20.1 & & $I$ \\
\hline P.10 & 13 & 2.60 & .28 & 0 & 0 & .71 & 1 & 17.6 & & I \\
\hline P. .28 & 12 & 2.62 & .33 & -.03 & -.09 & .64 & 1 & 9.6 & & IIa \\
\hline$R \cdot 36$ & 27 & 2.68 & .45 & +.03 & +.25 & .62 & 1 & 25.9 & & II a \\
\hline$R .55$ & 26 & 2.97 & .45 & 0 & +.03 & .86 & 7 & 10.1 & & ITb \\
\hline$R \cdot 70$ & 22 & 2.72 & .33 & +.03 & +.02 & .80 & 2 & 19.3 & & ITb \\
\hline$R .86$ & 23 & 3.02 & .41 & +.05 & +.04 & .74 & 3 & 16.7 & & $I T b$ \\
\hline R1.17 & 24 & 3.00 & .43 & 0 & -.02 & .71 & 6 & 13.9 & & IIb \\
\hline $\mathrm{R} 1.52$ & 25 & 3.15 & .42 & +.02 & +.02 & .67 & 5 & 14.2 & & IIb \\
\hline 5.12 & 101 & 2.43 & .28 & -.11 & -.27 & .69 & 1 & & & I \\
\hline$s .65$ & 103 & 2.52 & .52 & +.15 & +.27 & .58 & 4 & & & IIa \\
\hline S. .80 & 102 & 2.82 & .53 & +.06 & +.12 & .67 & 31 & & & IIa \\
\hline$\$ 1.05$ & 104 & 2.88 & .43 & +.06 & +.08 & .69 & 1 & & & VII \\
\hline 51.40 & 105 & 3.15 & .49 & +.05 & +.13 & .65 & 13 & & & VII \\
\hline U .01 & 100 & 2.60 & .22 & -.04 & -.16 & .70 & $<1$ & & & I \\
\hline $\mathrm{U} .06$ & 99 & $\begin{array}{l}2.55 \\
2.42\end{array}$ & $\begin{array}{l}.24 \\
.28\end{array}$ & $\begin{array}{l}-.10 \\
+.14\end{array}$ & $\begin{array}{l}-.28 \\
+.36\end{array}$ & $\begin{array}{l}.63 \\
.86\end{array}$ & $k 1$ & 10.5 & & I \\
\hline U1. 10 & 89 & 2.70 & .40 & +.06 & +.15 & .63 & 3 & & & II \\
\hline U1. 55 & 88 & 3.30 & .38 & -.10 & -.28 & .78 & 4 & & & IIb \\
\hline U1.85 & 87 & 3.45 & .35 & -.15 & +.54 & .92 & 4 & & & IIb \\
\hline $\mathrm{U} 2.50$ & 86 & 3.58 & .37 & -.03 & -.19 & .70 & 4 & & & ITb \\
\hline $\mathrm{U} 2.80$ & 85 & 3.47 & -.42 & -.06 & -.15 & .59 & 3 & & & IIb \\
\hline
\end{tabular}


APPENDIX ID (cont.)

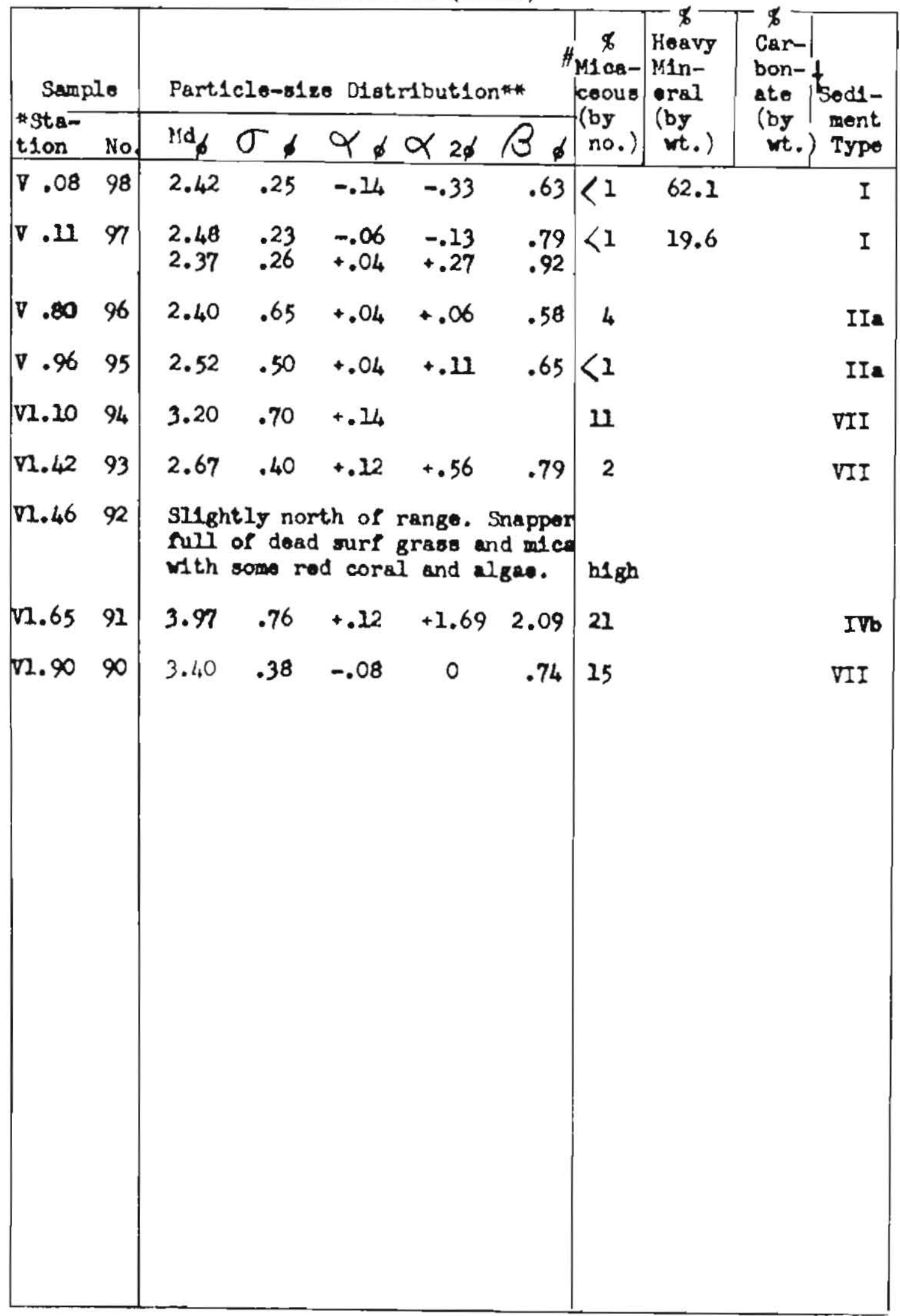




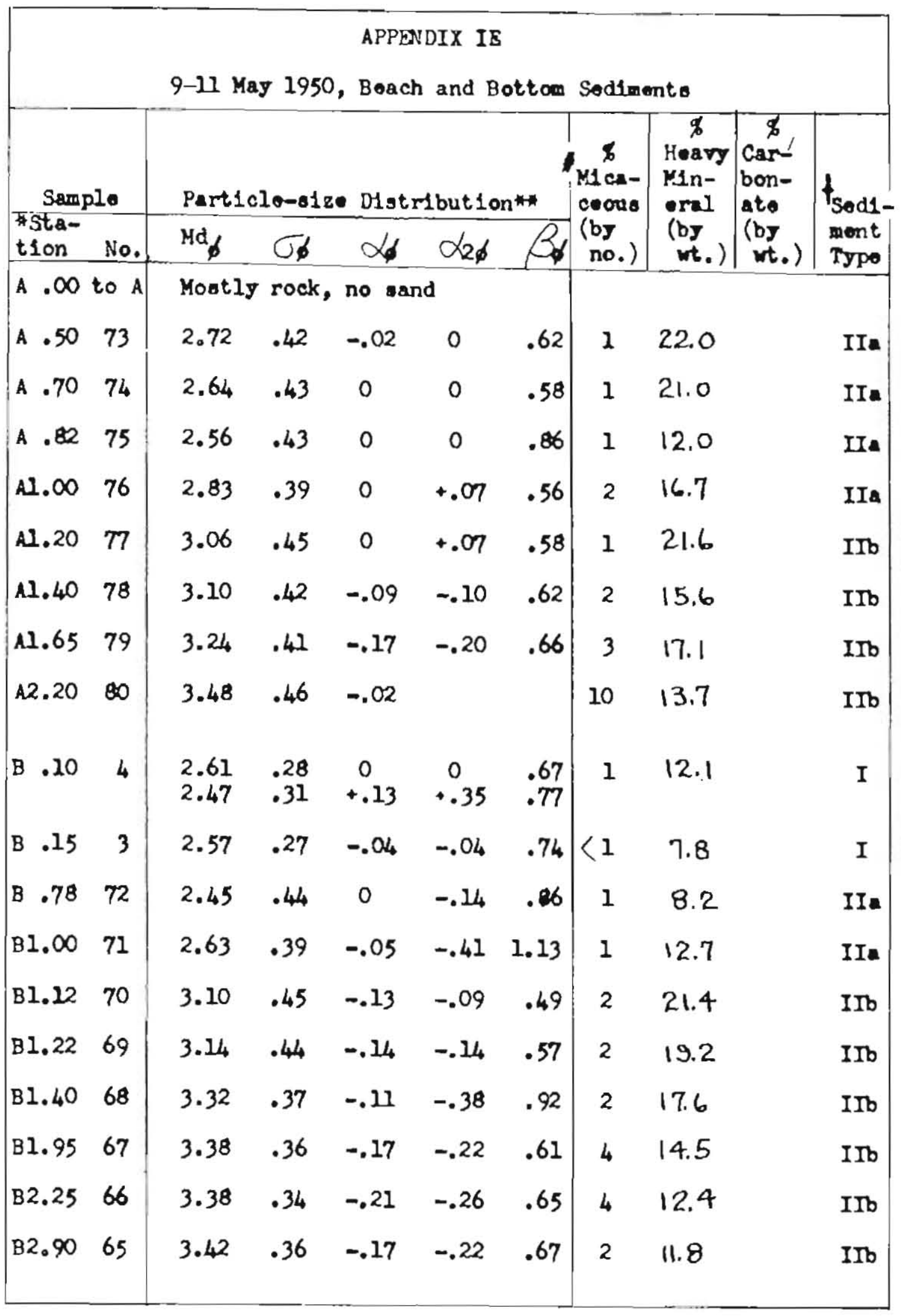


APPDIDIX IE (cont.)

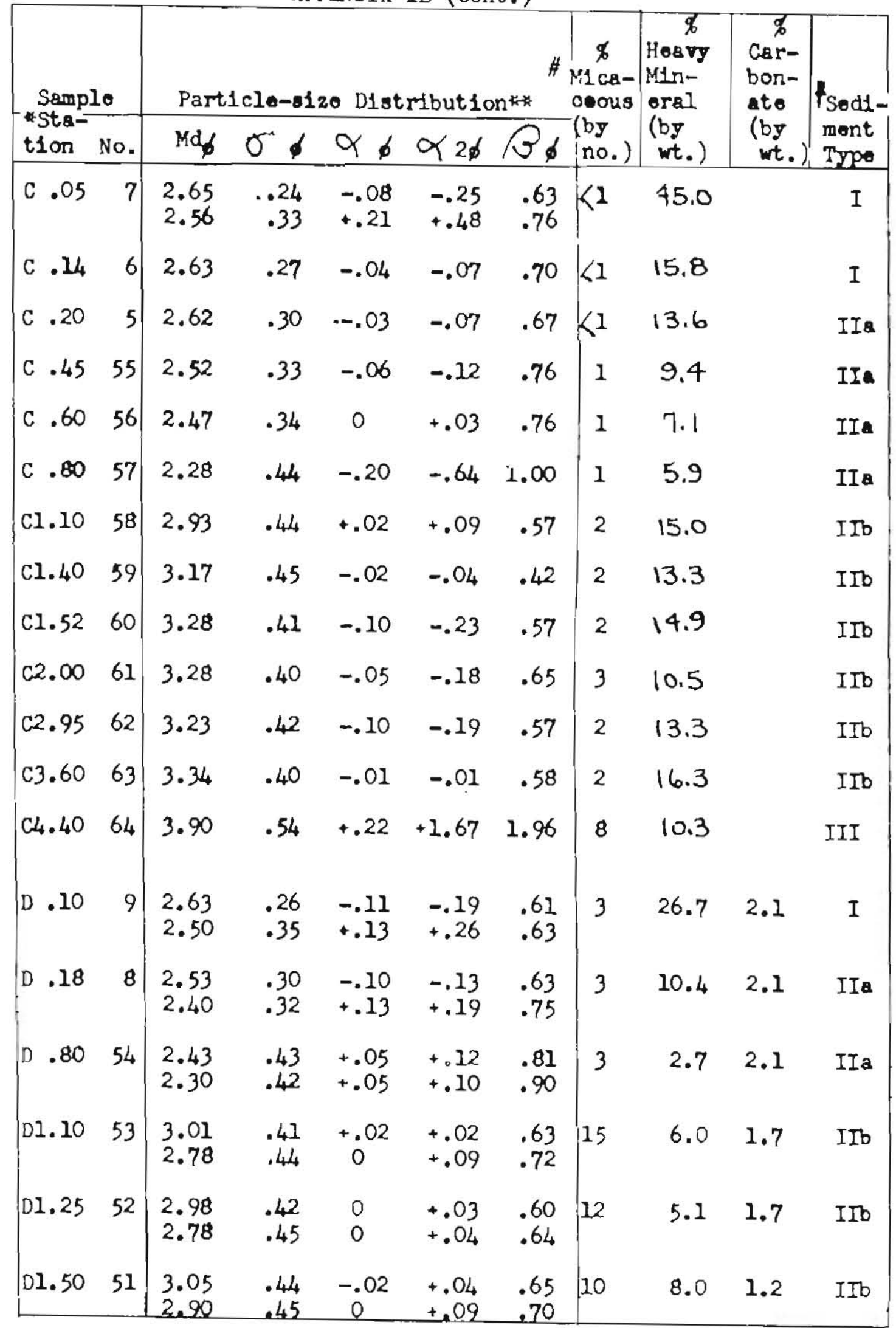




\begin{tabular}{|c|c|c|c|c|c|c|c|c|c|c|}
\hline \multirow{2}{*}{\multicolumn{2}{|c|}{ 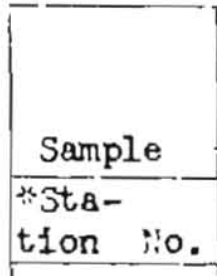 }} & \multicolumn{2}{|c|}{ Part1cle-81zo } & \multicolumn{2}{|c|}{ Distribut1on } & \multirow{2}{*}{\multicolumn{2}{|c|}{$\begin{array}{c}\underset{\sim}{d} \\
H_{1: 1 c a-} \\
\text { ceous } \\
-(\text { by } \\
\text { no.) }\end{array}$}} & \multirow{2}{*}{$\begin{array}{c}\bar{\phi} \\
\text { Heavy } \\
\because 1 \mathrm{In} \\
\text { eral } \\
\text { (by } \\
\text { wt. ) }\end{array}$} & \multirow{2}{*}{$\begin{array}{l}\% \\
\text { Car- } \\
\text { bon- } \\
\text { ate } \\
\text { (by } \\
\text { wt. ) }\end{array}$} & \multirow{2}{*}{$\begin{array}{l}\text { tseds - } \\
\text { ment } \\
\text { Type }\end{array}$} \\
\hline & & $\because d_{6}$ & $\sigma_{\phi}$ & $\alpha_{6}$ & $\alpha_{2 \phi}$ & & & & & \\
\hline $\mathrm{D} 1.80$ & 50 & $\begin{array}{l}3.13 \\
2.95\end{array}$ & $\begin{array}{l}.45 \\
.44\end{array}$ & $\begin{array}{l}-.07 \\
-.02\end{array}$ & -.11 & $\begin{array}{l}.64 \\
.72\end{array}$ & 3 & 5.7 & 1.0 & IIb \\
\hline$D 2.40$ & 49 & $\begin{array}{l}3.29 \\
3.08\end{array}$ & .41 & $\begin{array}{l}-.17 \\
-.08\end{array}$ & $\begin{array}{l}-.27 \\
-.12\end{array}$ & $\begin{array}{l}.58 \\
.68\end{array}$ & 3 & 11.6 & 0.8 & ITb \\
\hline D2.85 & 48 & $\begin{array}{l}3.28 \\
3.05\end{array}$ & $\begin{array}{l}.38 \\
.38\end{array}$ & $\begin{array}{l}-.05 \\
-.03\end{array}$ & -.11 & $\begin{array}{l}.63 \\
.73\end{array}$ & 2 & 14.3 & 0.9 & IIb \\
\hline D3.75 & 47 & $\begin{array}{l}3.24 \\
3.02\end{array}$ & $\begin{array}{l}.42 \\
.42\end{array}$ & $\begin{array}{l}-.05 \\
+.02\end{array}$ & $\begin{array}{l}-.24 \\
+.05\end{array}$ & $\begin{array}{l}.71 \\
.67\end{array}$ & 1 & 14.8 & 1.2 & IIb \\
\hline$D 4.40$ & 46 & $\begin{array}{l}3.78 \\
3.48\end{array}$ & $\begin{array}{r}.51 \\
.54\end{array}$ & $\begin{array}{l}+.16 \\
+.26\end{array}$ & $\begin{array}{l}+1.68 \\
+1.74\end{array}$ & $\begin{array}{l}2.03 \\
2.11\end{array}$ & 7 & 7.0 & 1.5 & III \\
\hline D5.25 & 45 & 4.03 & .62 & +.19 & 2.13 & 2.47 & & & & III \\
\hline E.18 & 1 & $\begin{array}{l}2.60 \\
2.44\end{array}$ & $\begin{array}{l}.28 \\
.29\end{array}$ & $\begin{array}{l}-.07 \\
+.10\end{array}$ & $\begin{array}{l}-.07 \\
+.34\end{array}$ & $\begin{array}{r}.57 \\
. .80\end{array}$ & 1 & 7.8 & & I \\
\hline E.20 & 10 & 2.52 & .27 & -.04 & -.07 & .66 & 1 & 5.7 & & I \\
\hline$E 1 . \infty$ & 44 & 2.83 & .39 & 0 & 0 & .49 & 1 & 19.2 & & IIa \\
\hline El.25 & 43 & 2.89 & .39 & -.03 & -.03 & .54 & 2 & 18.4 & & $\mathrm{ITb}$ \\
\hline $\mathrm{El} .45$ & 42 & 2.90 & .38 & 0 & +.02 & .551 & 2 & 17.1 & & I Ib \\
\hline 51.65 & 47 & 2.98 & .39 & -.13 & -.18 & .64 & 2 & 9.8 & & $I I b$ \\
\hline $\mathrm{E} 2.00$ & 40 & $\begin{array}{l}3.13 \\
2.98\end{array}$ & $\begin{array}{r}.56 \\
.60\end{array}$ & $\begin{array}{l}-.12 \\
-.13\end{array}$ &.- .11 & $\begin{array}{l}.52 \\
.67\end{array}$ & 45 & 9.3 & & IIb \\
\hline$E 2.80$ & 39 & 3.02 & .39 & 0 & +.03 & .54 & 3 & 17.2 & & IIb \\
\hline E3.40 & 38 & 3.14 & .42 & -.14 & -.14 & .59 & 3 & 13.5 & & IIb \\
\hline 84.40 & 37 & 3.80 & .58 & +.24 & +1.91 & 2.15 & 7 & 8.7 & & III \\
\hline E5. 55 & 36 & 4.07 & 1.73 & .52 & +.84 & .90 & 6 & 10.1 & & III \\
\hline
\end{tabular}


APPENDIX IE (cont.)

\begin{tabular}{|c|c|c|c|c|c|c|c|c|c|c|}
\hline \multirow{2}{*}{\multicolumn{2}{|c|}{\begin{tabular}{|l|} 
\\
Samplo \\
\#Sta- \\
tion No.
\end{tabular}}} & \multicolumn{2}{|c|}{ Particle-size } & \multicolumn{3}{|c|}{ Distribution } & \multirow{2}{*}{$\begin{array}{c}\% \\
\text { Helca- } \\
\text { ceous } \\
\text { (by } \\
\text { no.) }\end{array}$} & \multirow{2}{*}{\begin{tabular}{|}
$\phi$ \\
Heavy \\
Min- \\
oral \\
(by \\
wt.)
\end{tabular}} & \multirow{2}{*}{$\begin{array}{c}\text { क } \\
\text { car- } \\
\text { bon- } \\
\text { ato } \\
\text { by } \\
\text { wt. }\end{array}$} & \multirow{2}{*}{$\begin{array}{l}\text { tseds- } \\
\text { mont } \\
\text { Typo }\end{array}$} \\
\hline & & $\because \mathrm{d}_{\phi}$ & $\sigma_{6}$ & $\alpha_{6}$ & $\alpha_{26}$ & $\beta_{\phi}$ & & & & \\
\hline$F .08$ & 15 & $\begin{array}{l}2.68 \\
2.54\end{array}$ & $\begin{array}{l}.25 \\
.27\end{array}$ & $\begin{array}{c}0 \\
+.11\end{array}$ & $\begin{array}{r}+.04 \\
+.33\end{array}$ & $\begin{array}{l}.60 \\
.81\end{array}$ & 2 & 11.5 & & $I$ \\
\hline$F .18$ & $u_{4}$ & 2.56 & .27 & -.04 & -.07 & .67 & 1 & 8.0 & & $I$ \\
\hline$F .80$ & 35 & 2.52 & .37 & -.03 & 0 & .77 & 1 & 6.6 & & IIa \\
\hline$F .95$ & 34 & 2.77 & .46 & +.09 & +.13 & .47 & 1 & 11.5 & & II \\
\hline F1.15 & 33 & 2.88 & .40 & -.03 & 0 & .53 & 5 & 9.4 & & ITb \\
\hline Fl.25 & 32 & 3.08 & .38 & -.05 & -.05 & .58 & 3 & 11.1 & & IT \\
\hline F1.65 & 31 & 3.21 & .54 & +.09 & +.89 & -1.20 & 5 & 6.8 & & III \\
\hline G . 10 & 13 & $\begin{array}{l}2.39 \\
2.27\end{array}$ & .44 & $\begin{array}{l}-.28 \\
-.14\end{array}$ & $\begin{array}{l}-.62 \\
-.31\end{array}$ & $\begin{array}{l}.83 \\
.88\end{array}$ & 1 & 6.2 & & II a \\
\hline G . .22 & 12 & 2.60 & .30 & -.04 & -.07 & .69 & 1 & 8.5 & & IIs \\
\hline G .70 & 298 & 2.77 & .37 & -.03 & 0 & .54 & $<1$ & 14.1 & & II \\
\hline G . .82 & $29 A$ & 2.83 & .38 & 0 & 0 & .53 & 1 & 15.0 & & IIs \\
\hline G . 90 & 30 & 2.85 & .39 & 0 & +.08 & .46 & $<1$ & 13.7 & & II \\
\hline Gl.15 & 28 & 3.08 & .38 & -.02 & +.16 & .82 & 3 & 7.7 & & IIb \\
\hline G1.45 & 27 & 3.08 & .76 & -.25 & -.89 & 1.73 & 3 & 8.8 & & VII \\
\hline H. .15 & 17 & $\begin{array}{l}2.66 \\
2.55\end{array}$ & $\begin{array}{l}.50 \\
.60\end{array}$ & $\begin{array}{l}-.24 \\
-.35\end{array}$ & $\begin{array}{l}-.78 \\
-.75\end{array}$ & $\begin{array}{l}.90 \\
.87\end{array}$ & 2 & 39.1 & & $\nabla$ \\
\hline H. .2O & 16 & 2.57 & .54 & -.23 & -.63 & .72 & 2 & 6.2 & & $\nabla$ \\
\hline $\mathrm{H} .40$ & 26 & 3.12 & .37 & -.25 & -.33 & .57 & 5 & & & $\nabla$ \\
\hline H. .60 & 25 & 2.98 & .42 & -.16 & -.36 & .70 & 2 & 14.9 & & $\nabla$ \\
\hline$H .90$ & 24 & 2.96 & .41 & -.20 & -.39 & .83 & 1 & 11.4 & & $\nabla$ \\
\hline $\mathrm{Hl}, 40$ & 23 & 2.64 & .86 & -.33 & -1.42 & 1.36 & 1 & 9.1 & & $\nabla$ \\
\hline $\mathrm{HL} .43$ & 22 & Mud w & h one & ebble & & & 5 & $10: 9$ & & \\
\hline
\end{tabular}


APFENDIX IE (cont.)

\begin{tabular}{|c|c|c|c|c|c|c|c|c|c|c|}
\hline Sanpl & & Part 1 & $10-120$ & Dst & Abat 10 & & $\begin{array}{c}x \\
\text { M1co- } \\
\text { cecous }\end{array}$ & $\begin{array}{c}\% \\
\text { Heavy } \\
\text { Min- } \\
\text { eral }\end{array}$ & $\begin{array}{c}8 \\
\text { Car- } \\
\text { bon- } \\
\text { ate }\end{array}$ & \\
\hline $\begin{array}{l}\text { *Sta- } \\
\text { t1on }\end{array}$ & No. & $\mathrm{Md}_{\phi}$ & $\sigma_{\phi}$ & $\alpha 6$ & $\alpha_{26}$ & $\beta$ & $\left(\begin{array}{c}\text { (by } \\
\text { no. })\end{array}\right)$ & $\begin{array}{c}\text { (bJ } \\
\text { wt. })\end{array}$ & $\left.\begin{array}{c}(b y \\
w t .)\end{array}\right)$ & $\begin{array}{l}\text { mont } \\
\text { Typo }\end{array}$ \\
\hline$I 1.00$ & 21 & 3.17 & .48 & -.31 & -.89 & 1.09 & 2 & & & $\nabla$ \\
\hline 11.35 & 20 & 3.25 & .66 & -.52 & -.94 & .68 & 6 & & & $\nabla$ \\
\hline 11.80 & 19 & 2.79 & .49 & -.44 & -.83 & .72 & 1 & & & $\nabla$ \\
\hline 12.25 & 18 & $\begin{array}{r}1.13 \\
.98\end{array}$ & $\begin{array}{l}.27 \\
.34\end{array}$ & $\begin{array}{r}+.22 \\
+.26\end{array}$ & $\begin{array}{r}+.85 \\
+1.06\end{array}$ & $\begin{array}{l}1.15 \\
1.21\end{array}$ & $<1$ & & & $\nabla$ \\
\hline$P .07$ & 2 & $\begin{array}{l}2.54 \\
2.38\end{array}$ & $\begin{array}{l}.28 \\
.32\end{array}$ & $\begin{array}{l}-.07 \\
+.12\end{array}$ & $\begin{array}{r}-.20 \\
+.38\end{array}$ & $\begin{array}{l}.67 \\
.78\end{array}$ & $<1$ & 15.4 & & $I$ \\
\hline$P .22$ & 1 & 2.52 & .30 & -.07 & -.23 & .67 & $<1$ & 14.1 & & IIa \\
\hline R. .12 & 81 & 2.64 & .43 & +.02 & +.09 & .58 & 1 & 18.0 & & IIa \\
\hline$R .22$ & 82 & 2.68 & .41 & +.07 & +.15 & .61 & 1 & 17.7 & & II \\
\hline$R \cdot 36$ & 83 & 2.80 & .44 & -.09 & -.02 & .50 & 1 & 27.0 & & IIA \\
\hline R. .55 & 94 & 3.20 & .40 & -.08 & -.02 & .6 & 6 & 11.2 & & ITb \\
\hline $\mathrm{R} .70$ & 85 & 3.03 & .44 & -.04 & +.07 & .57 & 2 & & & IIb \\
\hline$R .86$ & 86 & 3.02 & .43 & -.02 & +.02 & .51 & 1 & & & IIb \\
\hline RI. 17 & 87 & 3.30 & .42 & -.07 & -.14 & .62 & 7 & & & IIb \\
\hline RI. 52 & 88 & 3.30 & .40 & -.18 & -.31 & .77 & 2 & & & IIb \\
\hline$\$ .00$ & & No $\mathbf{s e}$ & 1, 1لع & rogk & nd $c a b$ & & & & & \\
\hline S . 55 & 92 & 2.45 & .48 & +.02 & 0 & .75 & 3 & & & IIs \\
\hline S. .82 & 91 & 2.82 & .50 & +.06 & +.18 & .56 & 6 & & & II \\
\hline Sl.00 & 90 & 3.27 & .32 & 0 & 0 & .71 & 2 & & & VII \\
\hline 52.40 & 89 & 2.23 & .42 & -.17 & -.29 & .74 & 4 & & & VII \\
\hline S1.85 & 93 & 3.54 & .21 & -.05 & -.27 & .91 & 4 & & & VII \\
\hline
\end{tabular}

IE-5 
ACPFNDIX IE (cont.)

\begin{tabular}{|c|c|c|c|c|c|c|c|c|c|c|}
\hline Sampl & & Part & $0-31 z e$ & Dst & but1or & & $\mid \begin{array}{c}6 \\
\mathrm{M} 1 \mathrm{c} \theta- \\
\operatorname{coc} \theta\end{array}$ & $\begin{array}{c}\% \\
\text { Heavy } \\
\text { Min- } \\
\text { eral }\end{array}$ & $\begin{array}{l}\% \\
\text { Car- } \\
\text { bon- } \\
\text { ato }\end{array}$ & \\
\hline $\begin{array}{l}\text { Pista- } \\
\text { t1on }\end{array}$ & No. & $r_{\phi}$ & $\sigma_{\varnothing}$ & $\infty 6$ & $\alpha_{R \phi}$ & 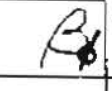 & (by $)$ & $\begin{array}{l}\text { (by } \\
\text { wt. })\end{array}$ & $\begin{array}{l}\text { (by } \\
\text { wt. }\end{array}$ & $\begin{array}{l}\text { ment } \\
\text { Type }\end{array}$ \\
\hline$U .02$ & 108 & $\begin{array}{l}2.39 \\
2.22\end{array}$ & $\begin{array}{r}.30 \\
.28\end{array}$ & $\begin{array}{c}-.13 \\
0\end{array}$ & $\begin{array}{r}-.30 \\
+.14\end{array}$ & $\begin{array}{l}.53 \\
.86\end{array}$ & $<1$ & & & I \\
\hline 12. & 107 & 2.25 & .41 & -.20 & -.34 & .66 & 1 & & & IIa \\
\hline Ul.10 & 106 & 2.87 & .45 & -.02 & -.02 & .58 & 2 & & & II \\
\hline U1. 55 & 105 & 3.28 & .43 & -.19 & -.35 & .42 & 1 & & & IIb \\
\hline U1.85 & 104 & 3.32 & .44 & 0 & -.14 & .54 & 1 & & & ITb \\
\hline U2.15 & 100 & 3.58 & .34 & -.21 & -.47 & .76 & 6 & & & IIb \\
\hline $\mathrm{U} 2.80$ & 99 & 3.54 & .33 & -.12 & -.28 & .81 & 2 & & & IIb \\
\hline $\mathrm{V} .08$ & 110 & $\begin{array}{l}2.51 \\
2.46\end{array}$ & $\begin{array}{r}.25 \\
.31\end{array}$ & $\begin{array}{l}-.04 \\
+.09\end{array}$ & $\begin{array}{l}-.04 \\
+.39\end{array}$ & $\begin{array}{l}.64 \\
.81\end{array}$ & $<1$ & & & $I$ \\
\hline $\mathrm{V} .18$ & 109 & 2.39 & .31 & -.06 & -.10 & .71 & $<1$ & & & IIa \\
\hline V.80 & 98 & 2.63 & .48 & 0 & -.02 & .62 & 3 & & & II \\
\hline V . 95 & 97 & 2.57 & .42 & 0 & +.07 & .72 & 4 & & & IIa \\
\hline V1.15 & 96 & 2.91 & .44 & +.27 & -.02 & .93 & 7 & & & VII \\
\hline $\mathrm{V} 1.45$ & 95 & $\begin{array}{l}3.20 \\
2.72\end{array}$ & $\begin{array}{l}.62 \\
.96\end{array}$ & $\begin{array}{l}+.06 \\
-.23\end{array}$ & $\begin{array}{l}+.40 \\
-.61\end{array}$ & $\begin{array}{l}.87 \\
.81\end{array}$ & 30 & & & VII \\
\hline v1.65 & 94 & 3.65 & .55 & +.07 & +.46 & 1.0 & 10 & & & IVb \\
\hline
\end{tabular}




\begin{tabular}{|c|c|c|c|c|c|c|c|c|c|c|}
\hline \multicolumn{11}{|c|}{$\begin{array}{l}\text { APPEYOIX IF } \\
\text { 1951, Beach } 8\end{array}$} \\
\hline \multicolumn{2}{|c|}{ Sample } & \multicolumn{2}{|c|}{ Part $1 \mathrm{cl} \theta-31 \mathrm{z}$} & \multicolumn{3}{|c|}{ Distribution:* } & \multirow{2}{*}{$\begin{array}{c}\% \\
\text { Naca- } \\
\text { ceous } \\
\text { (by } \\
\text { no. })\end{array}$} & \multirow{2}{*}{$\begin{array}{c}\not{g} \\
\text { Heavy } \\
\text { Min- } \\
\text { eral } \\
\text { (by } \\
\text { wt.) }\end{array}$} & \multirow{2}{*}{$\begin{array}{c}\$ \\
\text { Car- } \\
\text { bon- } \\
\text { ate } \\
\text { (by } \\
\text { wt.) }\end{array}$} & \multirow{2}{*}{$\begin{array}{l}\text { tsed1- } \\
\text { ment } \\
\text { Typo }\end{array}$} \\
\hline $\begin{array}{l}\text { Sta- } \\
\text { tion }\end{array}$ & No. & $\mathrm{Nid}_{\phi}$ & J6 & $0 \times 6$ & $c_{26}$ & 26 & & & & \\
\hline$D .08$ & 30 & $\begin{array}{l}2.42 \\
2.15\end{array}$ & $\begin{array}{l}.30 \\
.35\end{array}$ & $\begin{array}{c}-.20 \\
0\end{array}$ & $\begin{array}{l}-.40 \\
-.06\end{array}$ & $\begin{array}{l}.77 \\
.60\end{array}$ & $<1$ & & & I \\
\hline D. .15 & 29 & $\begin{array}{l}2.57 \\
2.46\end{array}$ & $\begin{array}{l}.31 \\
.34\end{array}$ & -.03 & $\begin{array}{l}-.10 \\
+.03\end{array}$ & $\begin{array}{l}.67 \\
.68\end{array}$ & $<1$ & & & II 8 \\
\hline$D .32$ & 28 & $\begin{array}{l}2.27 \\
2.12\end{array}$ & $\begin{array}{l}.52 \\
.63\end{array}$ & $\begin{array}{l}-.37 \\
-.22\end{array}$ & $\begin{array}{l}-.63 \\
-.54\end{array}$ & .80 & 4 & & & IIa \\
\hline D. .60 & 27 & $\begin{array}{l}2.70 \\
2.56\end{array}$ & $\begin{array}{l}.47 \\
.47\end{array}$ & $\begin{array}{l}-.06 \\
-.08\end{array}$ & $\begin{array}{l}-.21 \\
-.28\end{array}$ & $\begin{array}{l}.64 \\
.83\end{array}$ & 1 & & & IIa \\
\hline 0.90 & 26 & $\begin{array}{l}2.50 \\
2.37\end{array}$ & $\begin{array}{l}.42 \\
.52\end{array}$ & $\begin{array}{l}-.02 \\
-.10\end{array}$ & $\begin{array}{l}-.02 \\
-.08\end{array}$ & $\begin{array}{l}.76 \\
.60\end{array}$ & 2 & & & II 8 \\
\hline 01.25 & 25 & $\begin{array}{l}2.90 \\
2.80\end{array}$ & $\begin{array}{l}.41 \\
.40\end{array}$ & $\begin{array}{l}+.02 \\
+.05\end{array}$ & $\begin{array}{l}-.07 \\
+.05\end{array}$ & $\begin{array}{l}.58 \\
.75\end{array}$ & 1 & & & IIb \\
\hline 01.80 & 24 & $\begin{array}{l}3.25 \\
2.97\end{array}$ & $\begin{array}{l}.40 \\
.36\end{array}$ & $\begin{array}{l}-.20 \\
-.03\end{array}$ & $\begin{array}{l}-.37 \\
-.08\end{array}$ & $\begin{array}{l}.62 \\
.74\end{array}$ & 5 & & & IIb \\
\hline 02.40 & $8 b$ & $\begin{array}{l}3.40 \\
3.12\end{array}$ & $\begin{array}{l}.37 \\
.35\end{array}$ & $\begin{array}{l}-.16 \\
-.06\end{array}$ & $\begin{array}{l}-.46 \\
-.23\end{array}$ & $\begin{array}{l}.70 \\
.90\end{array}$ & 4 & & & $I I b$ \\
\hline 02.65 & 70 & $\begin{array}{l}3.35 \\
3.10\end{array}$ & $\begin{array}{l}.36 \\
.35\end{array}$ & $\begin{array}{c}-.11 \\
0\end{array}$ & $\begin{array}{l}-.28 \\
-.11\end{array}$ & $\begin{array}{l}.72 \\
.86\end{array}$ & 1 & & & IIb \\
\hline 02.85 & $6 \mathrm{~b}$ & $\begin{array}{l}3.28 \\
3.10\end{array}$ & $\begin{array}{l}.36 \\
.35\end{array}$ & $\begin{array}{l}-. u_{4} \\
-.09\end{array}$ & $\begin{array}{l}-.36 \\
-.20\end{array}$ & $\begin{array}{l}.75 \\
.80\end{array}$ & 1 & & & ITb \\
\hline D3.10 & $5 b$ & $\begin{array}{l}3.35 \\
3.10\end{array}$ & $\begin{array}{l}.39 \\
.37\end{array}$ & $\begin{array}{l}-.03 \\
-.08\end{array}$ & $\begin{array}{l}-.18 \\
-.16\end{array}$ & $\begin{array}{l}.74 \\
.89\end{array}$ & & & & IIb \\
\hline D3. 40 & $4 b$ & $\begin{array}{l}3.30 \\
3.10\end{array}$ & $\begin{array}{r}.39 \\
.35\end{array}$ & -.10 & $\begin{array}{l}-.26 \\
-. u_{4}\end{array}$ & $\begin{array}{r}.67 \\
.94\end{array}$ & 2 & & & In \\
\hline D3.70 & $3 b$ & $\begin{array}{l}3.30 \\
3.10\end{array}$ & $\begin{array}{r}.37 \\
.38\end{array}$ & $\begin{array}{l}-.16 \\
-.05\end{array}$ & $\begin{array}{l}-.38 \\
-.11\end{array}$ & $\begin{array}{l}.73 \\
.82\end{array}$ & 1 & & & $I T b$ \\
\hline
\end{tabular}


APPEIDI? IP (cont.)

\begin{tabular}{|c|c|c|c|c|c|c|c|c|c|}
\hline \multirow{2}{*}{$\begin{array}{l}\text { Sample } \\
\text { Sta- } \\
\text { tion No. }\end{array}$} & \multicolumn{2}{|c|}{ Part1cle-s1ze } & \multicolumn{3}{|c|}{ - Distribution } & \multirow{2}{*}{$\left|\begin{array}{c}q \\
\text { M1ca- } \\
\text { ceous } \\
(\text { by } \\
\text { no. })\end{array}\right|$} & \multirow{2}{*}{$\begin{array}{l}\text { a } \\
\text { Hesvy } \\
\text { Min- } \\
\text { eral } \\
\text { (by } \\
\text { wt.) }\end{array}$} & \multirow{2}{*}{$\begin{array}{l}q 6 \\
\text { Car- } \\
\text { bon- } \\
\text { ate } \\
\text { (by } \\
\text { wt.) }\end{array}$} & \multirow{2}{*}{$\begin{array}{c}\text { tseds- } \\
\text { ment } \\
\text { Type }\end{array}$} \\
\hline & $* \mathrm{~d}_{6}$ & $\pi \phi$ & $x_{6}$ & $\chi_{26}$ & $\beta_{\phi}$ & & & & \\
\hline D3.95 28 & $\begin{array}{l}3.38 \\
3.15\end{array}$ & $\begin{array}{r}.41 \\
.36\end{array}$ & $\begin{array}{c}0 \\
-.06\end{array}$ & $\begin{array}{l}+.10 \\
+.08\end{array}$ & $\begin{array}{r}.90 \\
.83\end{array}$ & 2 & & & IIb \\
\hline $\mathrm{D} 4.10 \quad 2 \mathrm{~b}$ & $\begin{array}{l}3.40 \\
3.15\end{array}$ & $\begin{array}{r}.41 \\
.35\end{array}$ & $\begin{array}{l}0 \\
0\end{array}$ & $\begin{array}{r}+.15 \\
-.06\end{array}$ & $\begin{array}{r}1.02 \\
.88\end{array}$ & 2 & & & ITo \\
\hline $\mathrm{D} 4.35 \mathrm{Ib}$ & $\begin{array}{l}3.71 \\
3.27\end{array}$ & $\begin{array}{l}.46 \\
.47\end{array}$ & $\begin{array}{r}+.05 \\
+.36\end{array}$ & $\begin{array}{r}+.74 \\
+.32\end{array}$ & $\begin{array}{r}1.41 \\
.70\end{array}$ & 3 & & & III \\
\hline
\end{tabular}




\section{APPENDIX II \\ Particle-size DAstribution}

and

Values of Selected Sediment Components

for

Supplementary Semples 


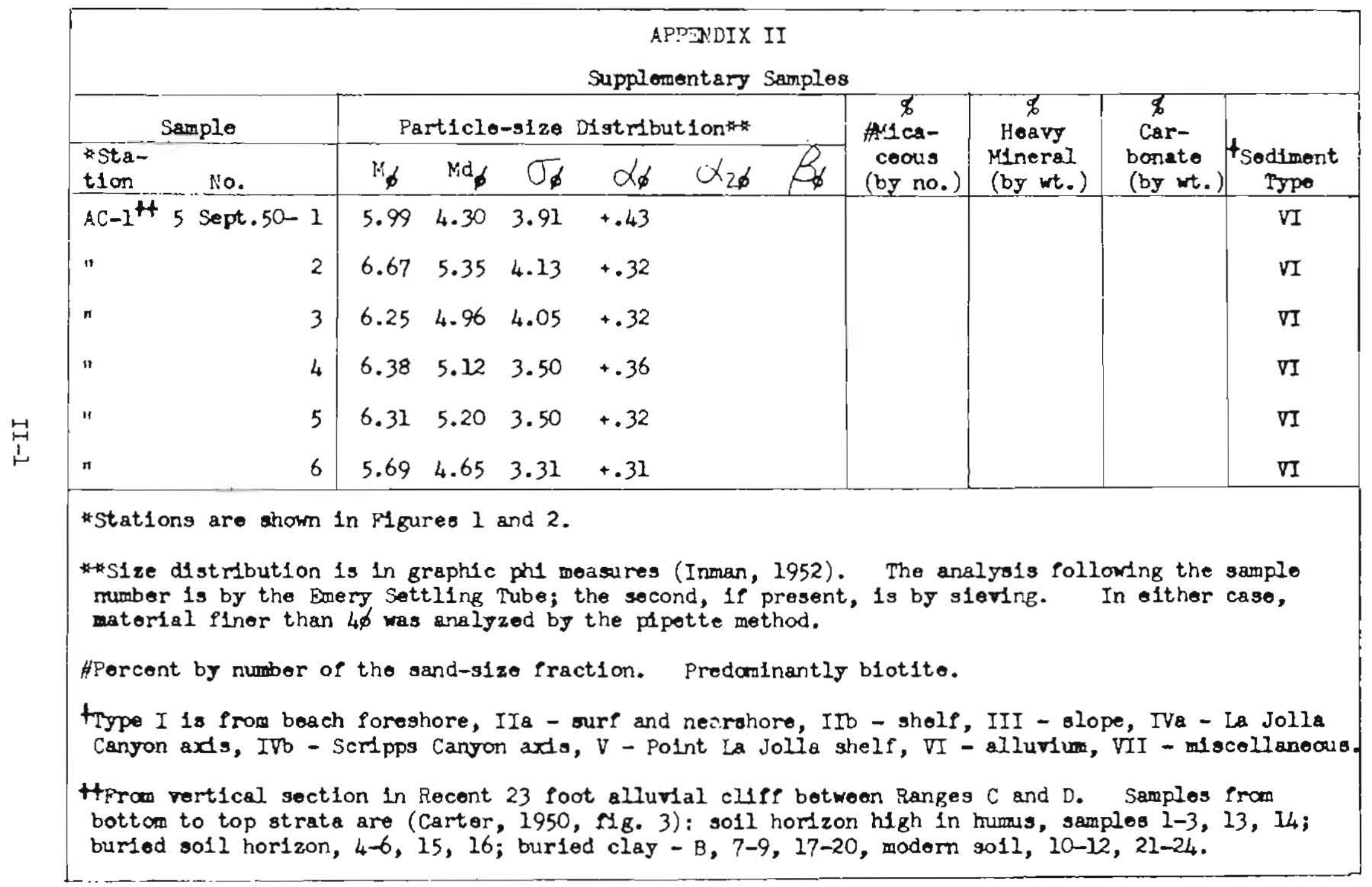




\begin{tabular}{|c|c|c|c|c|c|c|c|c|c|c|c|}
\hline \multicolumn{3}{|c|}{ Samplo } & \multicolumn{5}{|c|}{ Particle-size Distribution $\# *$} & \multirow{2}{*}{$\begin{array}{c}\text { of } \\
\text { ff:1 ca- } \\
\text { ceous } \\
\text { (by no.) }\end{array}$} & \multirow{2}{*}{$\begin{array}{c}\text { Heavy } \\
\text { MIneral } \\
\text { (by wt.) }\end{array}$} & \multirow{2}{*}{$\begin{array}{c}\text { g } \\
\text { Car- } \\
\text { bonate } \\
\text { (by wt.) }\end{array}$} & \multirow{2}{*}{$t_{\text {Sediment }}$} \\
\hline $\begin{array}{l}\text { *Sto- } \\
\text { t1on }\end{array}$ & No. & & $M_{6}$ & $\mathrm{Md}_{\phi}$ & $\sigma_{6}$ & $\alpha_{6}$ & $\alpha_{2 \phi} \quad \beta_{\phi}$ & & & & \\
\hline $\mathrm{AC}^{-1} \mathrm{I}^{+7}$ & 5 sept. 5 & & 6.47 & 5.28 & 2.53 & +.47 & & & & & VI \\
\hline$"$ & & 8 & 6.45 & 5.25 & 3.50 & +.34 & & & & & VI \\
\hline$"$ & & 9 & 7.16 & 6.04 & 3.54 & +.32 & & & & & VI \\
\hline$"$ & & 10 & 5.81 & 4.12 & 3.94 & +.43 & & & & & VI \\
\hline$\pi$ & & 11 & 6.16 & 5.31 & 4.04 & +.21 & & & & & VI \\
\hline$"$ & & 12 & 3.68 & 2.95 & 2.28 & +.32 & & & & & VI \\
\hline $\mathrm{AC}-2^{++}$ & 5 sept. 5 & -13 & 5.85 & 4.86 & 3.82 & +.26 & & & & & VI \\
\hline$"$ & & 14 & 5.96 & 4.57 & 4.14 & +.34 & & & & & VI \\
\hline$"$ & & 15 & 5.41 & 4.12 & 3.10 & +.32 & & & & & VI \\
\hline$"$ & & 16 & 6.56 & 4.60 & 4.24 & +.46 & & & & & VI \\
\hline$"$ & & 17 & 7.44 & 6.37 & 3.86 & +.28 & & & & & VI \\
\hline$"$ & & 18 & 7.90 & 6.48 & 3.90 & +.36 & & & & & VI \\
\hline " & & 19 & 7.35 & 6.12 & 3.65 & +.34 & & & & & VI \\
\hline$"$ & & 20 & 8.00 & 6.66 & 3.80 & +.35 & & & & & VI \\
\hline$"$ & & 21 & $5: 12$ & 4.28 & 2.29 & +.37 & & & & & VI \\
\hline " & & 22 & 6.44 & 5.14 & 3.34 & +.39 & & & & & VI \\
\hline
\end{tabular}




\begin{tabular}{|c|c|c|c|c|c|c|c|c|c|c|c|c|}
\hline \multicolumn{3}{|c|}{ Sample } & \multicolumn{6}{|c|}{ Part1cle-size D1stribution } & \multirow{2}{*}{$\begin{array}{c}\% \\
\text { Mics- } \\
\text { coous } \\
\text { (by no.) }\end{array}$} & \multirow{2}{*}{$\begin{array}{c}\$ \\
\text { Hoavy } \\
\text { MIneral } \\
\text { (by wt.) }\end{array}$} & \multirow{2}{*}{$\begin{array}{c}\% \\
\text { Car- } \\
\text { bonste } \\
\text { (by wt.) }\end{array}$} & \multirow[b]{2}{*}{$\begin{array}{c}t_{\text {Sediment }} \\
\text { Type }\end{array}$} \\
\hline $\begin{array}{l}\text { *Sta- } \\
\text { tion }\end{array}$ & \multicolumn{2}{|c|}{ No. } & ${ }^{1} 6$ & $\mathrm{Yd}_{6}$ & $\sigma_{6}$ & $\alpha_{\phi}$ & $\alpha_{2, \phi}$ & $\beta_{6}$ & & & & \\
\hline$A C-2^{4}$ & 5 Sept & $.50-23$ & 7.31 & 5.82 & 4.79 & +.31 & & & & & & VI \\
\hline " & & 24 & 4.22 & 3.95 & 2.19 & +.12 & & & & & & VI \\
\hline $1-1$ & I Jul & 49-111 & $\begin{array}{l}.95 \\
.82\end{array}$ & $\begin{array}{r}1.07 \\
.92\end{array}$ & $\begin{array}{l}.57 \\
.58\end{array}$ & $\begin{array}{l}-.21 \\
-.17\end{array}$ & $\begin{array}{l}-.63 \\
-.45\end{array}$ & $\begin{array}{l}.844 \\
.82\end{array}$ & $<1$ & 8.9 & 6.7 & $v$ \\
\hline$L-1$ & 21 Nay & 50 & Cobbles & 3 and $x$ & rock & & & & & & & \\
\hline$L-2$ & 24 Aug & $49-44$ & $\begin{array}{r}1.20 \\
.96\end{array}$ & $\begin{array}{r}1.22 \\
.98\end{array}$ & $\begin{array}{l}.26 \\
.26\end{array}$ & $\begin{array}{l}-.08 \\
-.08\end{array}$ & $\begin{array}{l}-.30 \\
-.23\end{array}$ & $\begin{array}{l}.58 \\
.61\end{array}$ & $<1$ & 0.8 & $u_{4.2}$ & $\nabla$ \\
\hline$L-3$ & 24 Aug & $49-45$ & $\begin{array}{l}1.33 \\
1.16\end{array}$ & $\begin{array}{l}1.37 \\
1.17\end{array}$ & $\begin{array}{l}.35 \\
.36\end{array}$ & $\begin{array}{l}-.11 \\
-.03\end{array}$ & -.20 & $\begin{array}{l}.60 \\
.80\end{array}$ & $<1$ & 1.9 & 10.2 & $\nabla$ \\
\hline $2-4$ & 7 Jan & $51-2$ & $\begin{array}{l}2.29 \\
\text { Bimodal }\end{array}$ & $\begin{array}{l}2.30 \\
12(\bmod \end{array}$ & $\begin{array}{l}1.05 \\
\text { es at }\end{array}$ & 1.66 and & $\begin{array}{r}-.12 \\
3.26)\end{array}$ & .33 & & & & $\nabla$ \\
\hline$I-5$ & 18 Doc & $50-1$ & $\begin{array}{l}-0.62 \\
\text { Bimodal }\end{array}$ & $1^{0.02}$ & 2.12 & -.30 & -.72 & .60 & & & & $\nabla$ \\
\hline $1-6$ & 17 Nov & $49-20$ & $\begin{array}{l}2.49 \\
\text { B1mods }\end{array}$ & $1^{2.93}$ & .96 & -.46 & -.55 & .38 & 2 & & & $v$ \\
\hline $\operatorname{Ln} 7$ & 22 Nov & $50-1$ & $\begin{array}{l}1.30 \\
1.14\end{array}$ & $\begin{array}{l}1.42 \\
1.17\end{array}$ & $\begin{array}{l}.47 \\
.44\end{array}$ & $\begin{array}{l}-.25 \\
-.07\end{array}$ & $\begin{array}{l}-.68 \\
-.30\end{array}$ & $\begin{array}{l}1.00 \\
1.02\end{array}$ & & 1.3 & $\mathbf{1 4 . 6}$ & $\nabla$ \\
\hline IB-1 & 1 Jul & 49-112 & $\begin{array}{l}.69 \\
.65\end{array}$ & $\begin{array}{l}.69 \\
.65\end{array}$ & $\begin{array}{l}.36 \\
.33\end{array}$ & $\begin{array}{l}0 \\
0\end{array}$ & $\begin{array}{l}-.03 \\
+.15\end{array}$ & $\begin{array}{l}.61 \\
.75\end{array}$ & $<1$ & 2.0 & 2.5 & I \\
\hline
\end{tabular}




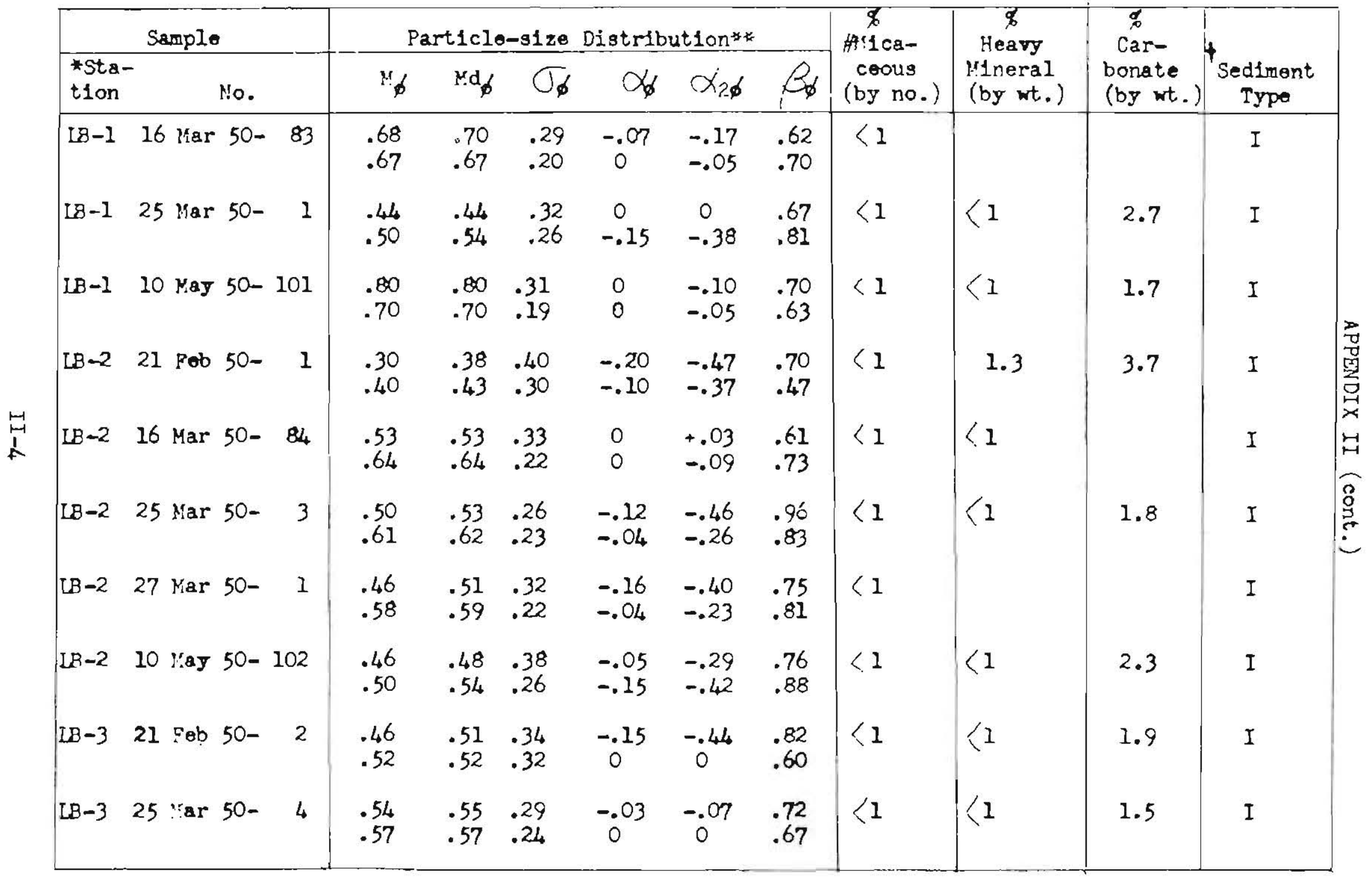




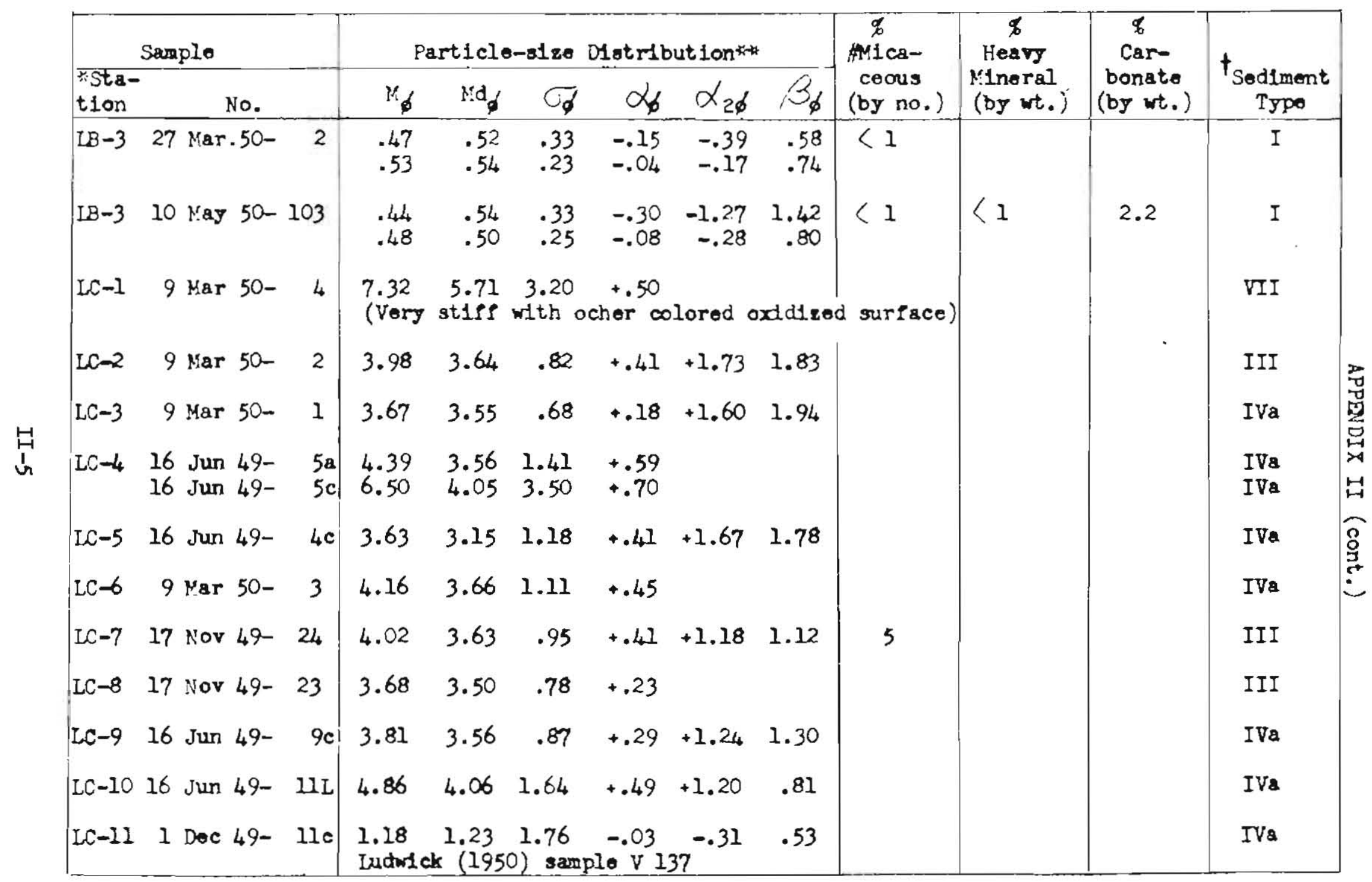




\begin{tabular}{|c|c|c|c|c|c|c|c|c|c|c|c|}
\hline \multicolumn{2}{|c|}{ Sermplo } & \multicolumn{6}{|c|}{ Particle-size Distribution $x$} & \multirow{2}{*}{$\begin{array}{c}\% \\
\text { Mlica- } \\
\text { ceous } \\
\text { (by no.) }\end{array}$} & \multirow{2}{*}{$\begin{array}{c}\sigma \\
\text { Heavy } \\
\text { Mineral } \\
\text { (by wt.) }\end{array}$} & \multirow{2}{*}{$\begin{array}{c}\dot{f} \\
\text { Car- } \\
\text { bonste } \\
\text { (by wt.) }\end{array}$} & \multirow[b]{2}{*}{$t_{\text {Sediment }}$ Type } \\
\hline $\begin{array}{l}\text { *Sta- } \\
\text { tion }\end{array}$ & No. & $M_{6}$ & $\mathrm{Md}_{6}$ & $\sigma_{6}$ & $\alpha_{6}$ & $\alpha_{2 \phi}$ & $\beta_{6}$ & & & & \\
\hline IC- 12 & $16 \mathrm{Jum} 49-80$ & 5.80 & 4.15 & 2.80 & +.59 & & & & & & $\mathrm{IVe}$ \\
\hline$I C-13$ & 17 Jun $49-120$ & 5.17 & 4.42 & 1.83 & +.42 & +.86 & .65 & & & & IVQ \\
\hline$I C-1 L_{4}$ & 17 Jun $49-120$ & 6.10 & 4.92 & 3.10 & +.38 & & & & & & III \\
\hline LC-15 & 1 Dec $49-90$ & 4.35 & 3.84 & 1.05 & +.49 & & & & & & IV. \\
\hline & $\begin{array}{l}71 \text { com. down) } \\
\text { from top }\end{array}$ & $\begin{array}{l}3.48 \\
\text { Iudwic }\end{array}$ & ${ }_{k}^{3.34}(195$ & $0) .60$ & +.23 & +1.33 & .54 & & & & \\
\hline LC-16 & 17 Jun $49-146$ & 4.17 & 3.40 & 1.33 & +.58 & & & & & & IVa \\
\hline LC -17 & I4 Dec 50- 5 & 5.57 & 4.06 & 2.23 & +.68 & & & & & & III \\
\hline$L C-18$ & I4 Dec 50- $7 \mathrm{c}$ & $\begin{array}{l}\text { Severa } \\
\text { fine: }\end{array}$ & $\begin{array}{l}1 \text { pebb: } \\
\text { and }(P \text {. }\end{array}$ & $\begin{array}{l}\text { les and } \\
\text { hleger }\end{array}$ & small & $\begin{array}{l}\text { amount } \\
\text { jemplor }\end{array}$ & & & & & IVe \\
\hline$s c-1$ & 14 sept $49-3$ & 3.53 & 3.41 & .68 & +.18 & & & & & & IVo \\
\hline $\mathrm{SC}-2$ & $\begin{aligned} & 14 \text { Sept } 49- \\
& 5 \mathrm{Apr} 50- 8 \\
&\end{aligned}$ & $\begin{array}{l}3.57 \\
3.30\end{array}$ & $\begin{array}{l}3.48 \\
3.25\end{array}$ & $\begin{array}{l}.51 \\
.56\end{array}$ & $\begin{array}{l}+.18 \\
+.09\end{array}$ & $\begin{array}{r}+1.18 \\
+.36\end{array}$ & $\begin{array}{r}1.55 \\
.88\end{array}$ & & & & $\begin{array}{l}\text { IDb } \\
\text { IDb }\end{array}$ \\
\hline$s c-3$ & $5 \mathrm{Apr} 50-$ & $\begin{array}{l}3.39 \\
3.23\end{array}$ & $\begin{array}{l}3.32 \\
3.14\end{array}$ & .54 & $\begin{array}{l}+.13 \\
+.15\end{array}$ & +.42 & .78 & 16 & 9.2 & 3.5 & IVO \\
\hline SC-4 & $5 \mathrm{Apr} 50-4$ & 3.54 & 3.40 & .68 & $+.21+$ & +2.843 & 3.07 & & & & IVb \\
\hline$S C-5$ & 17 Jun $49-17 \mathrm{~b}$ & 3.74 & 3.46 & .74 & +.38 & +.931 & 1.01 & & & & III \\
\hline
\end{tabular}




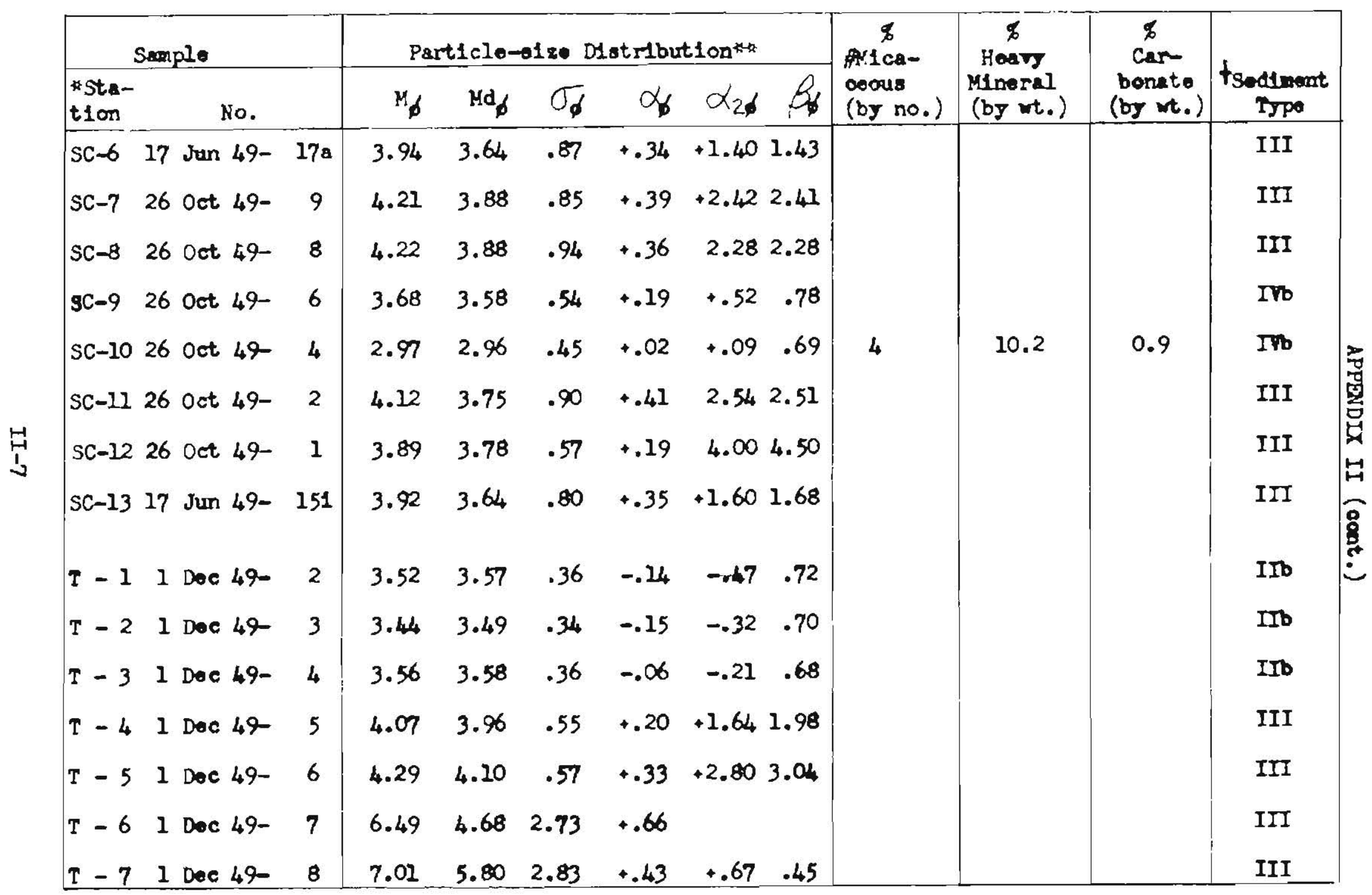




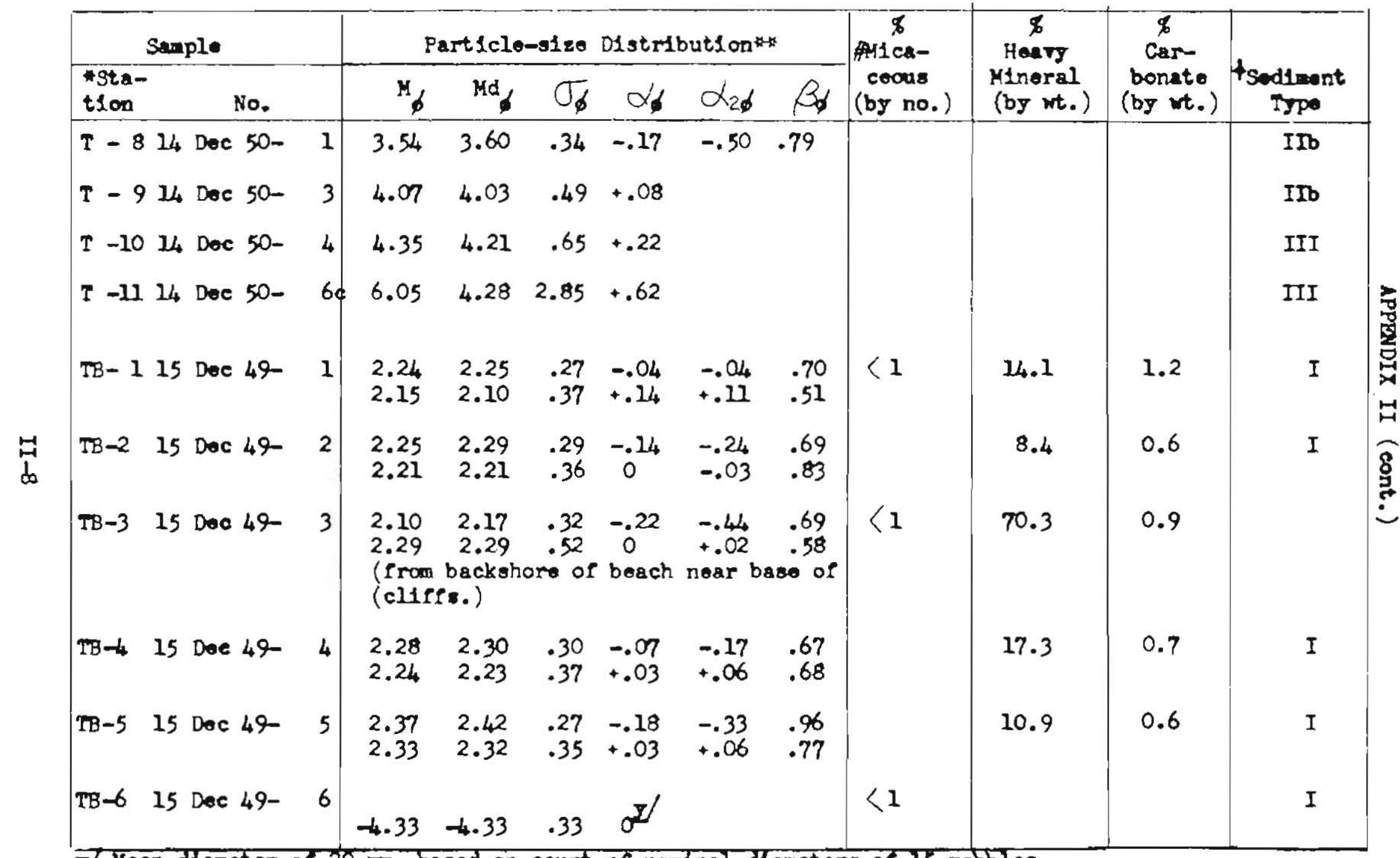

7 Mean draweter of 20 m. based on count of nominal dLameters of 15 pebbles. 


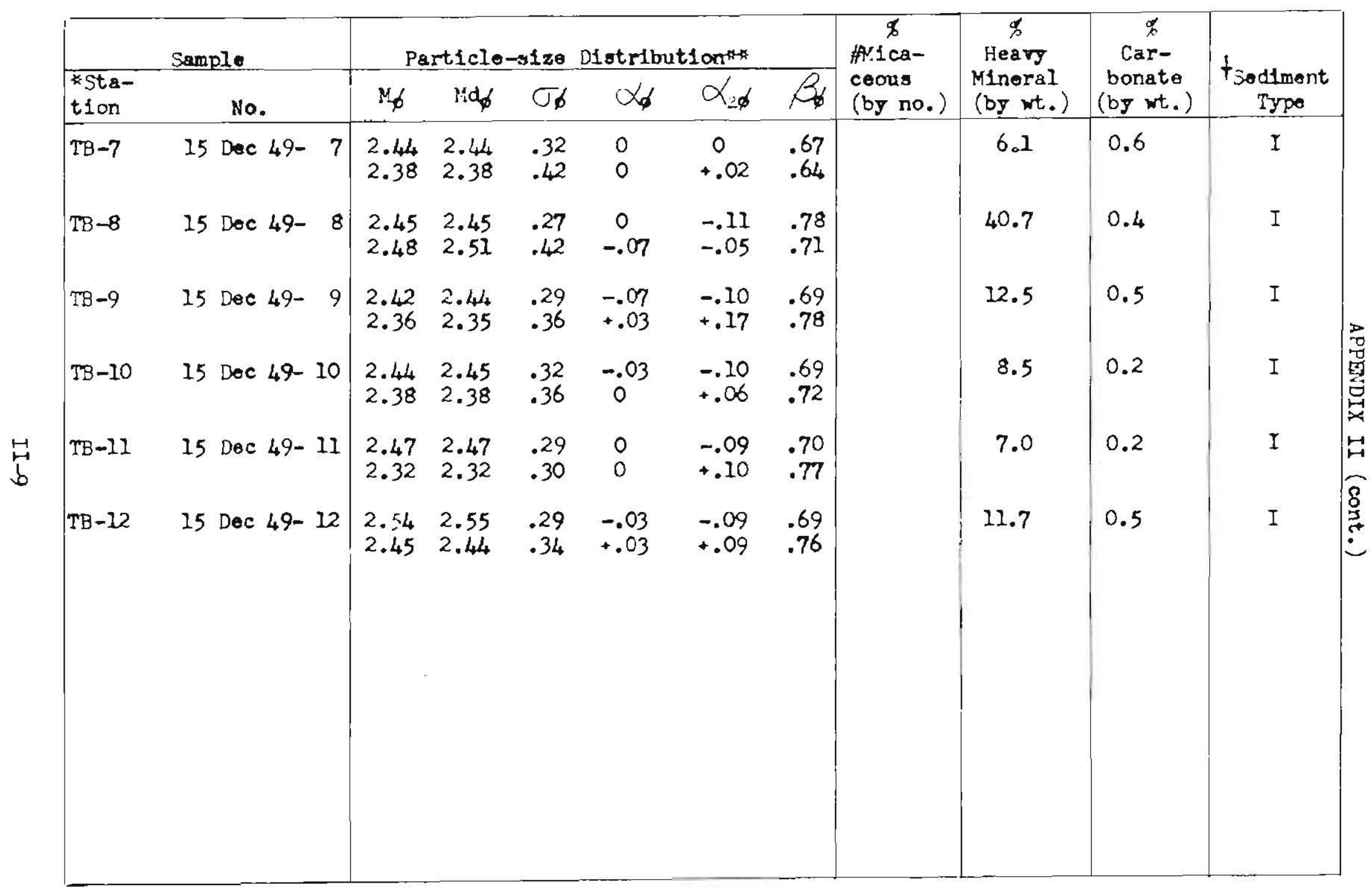


APPENDIX III

\section{Sand Size}

and

\section{Beach Foreshore Slope}




\section{APPENDIX III}

SAND-SIZE, NID BEACH FORESIOORE SLOPE

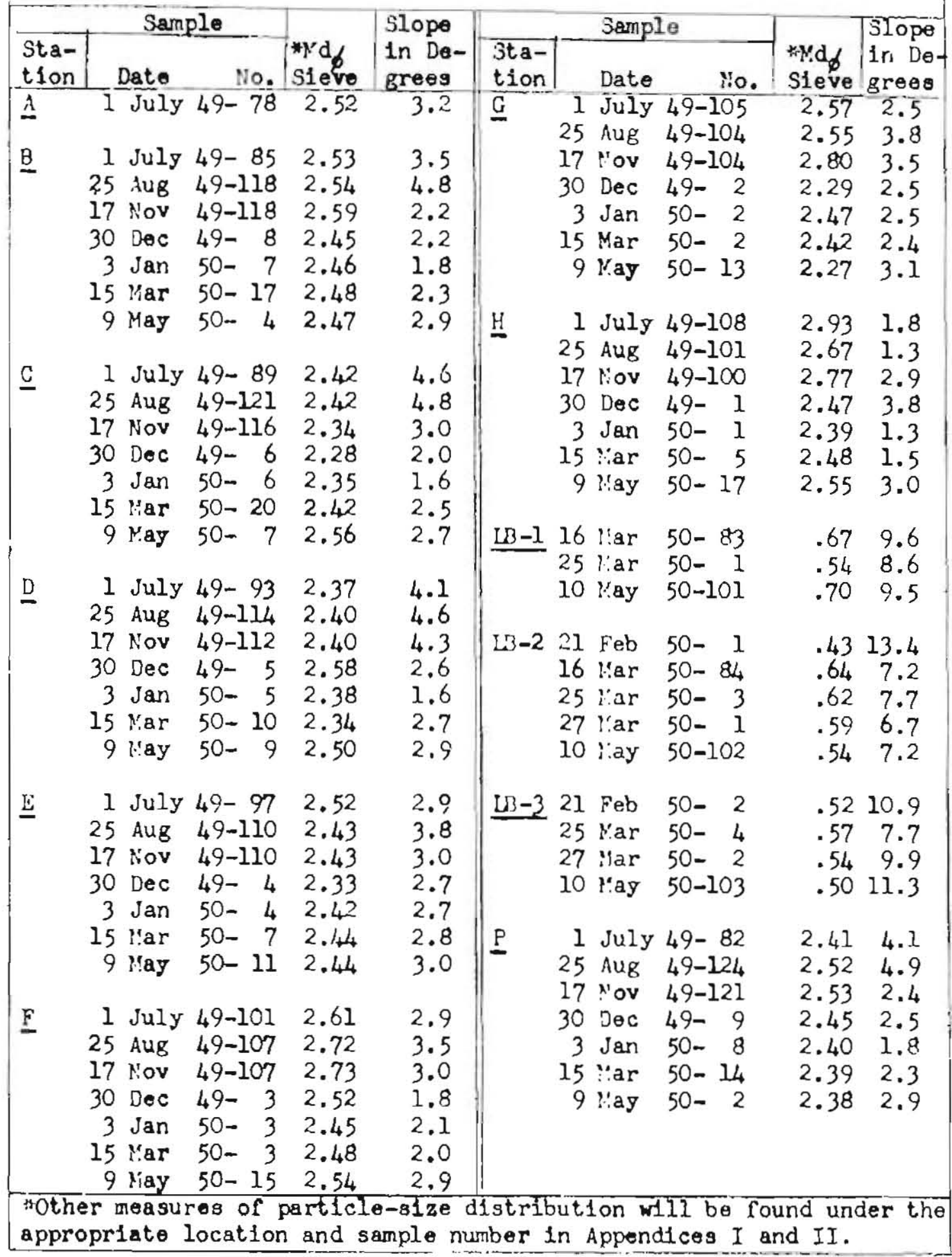


APFE IXIX III (cont.)

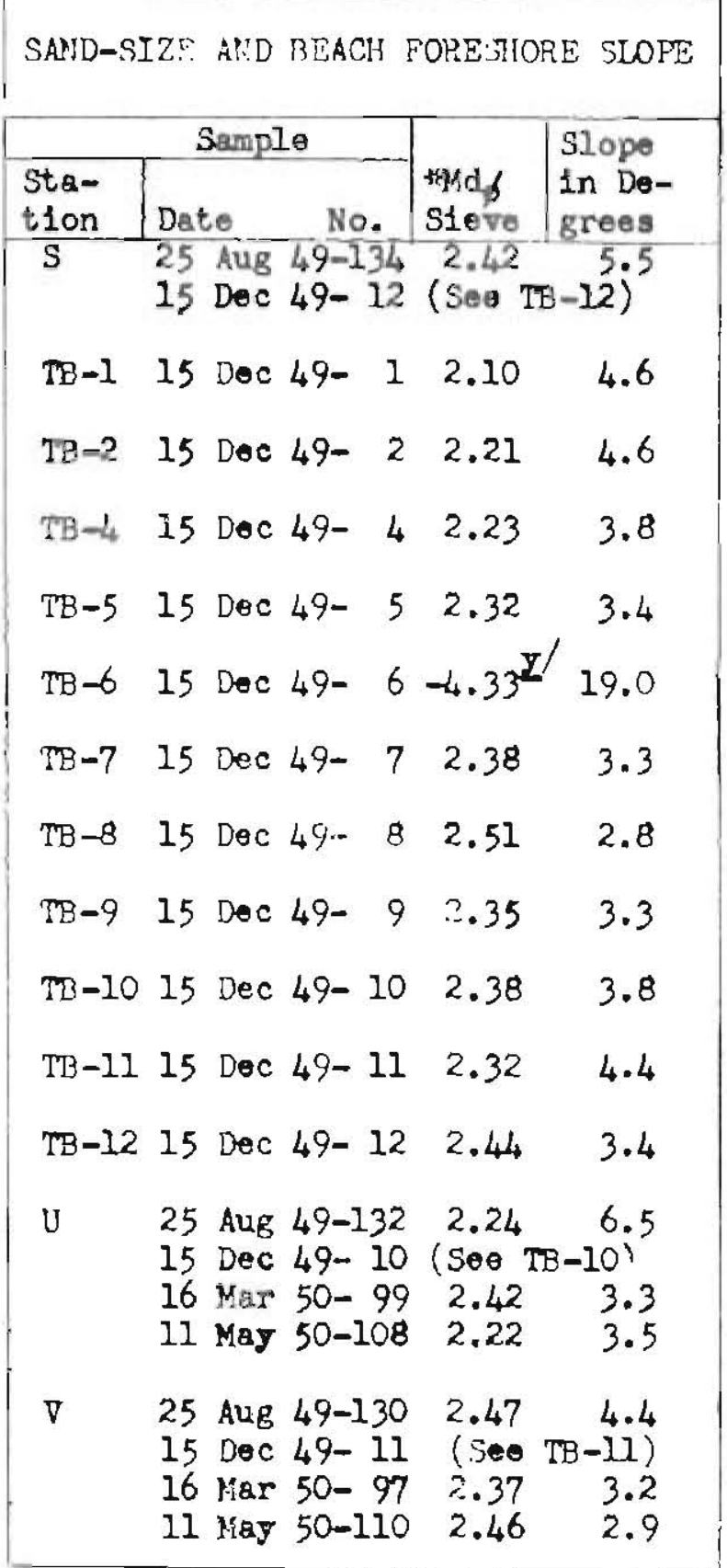

$y /$ Median of $20 \mathrm{mased}$ on the nominal diameters of 15 pebbles.

9593055 